Portland State University

PDXScholar

11-3-1994

\title{
Oregon's Marines: A Regional History of the United States Marine Corps
}

Michael Coleman Howard

Portland State University

Follow this and additional works at: https://pdxscholar.library.pdx.edu/open_access_etds

Part of the History Commons

Let us know how access to this document benefits you.

Recommended Citation

Howard, Michael Coleman, "Oregon's Marines: A Regional History of the United States Marine Corps" (1994). Dissertations and Theses. Paper 4768.

https://doi.org/10.15760/etd.6652

This Thesis is brought to you for free and open access. It has been accepted for inclusion in Dissertations and Theses by an authorized administrator of PDXScholar. Please contact us if we can make this document more accessible: pdxscholar@pdx.edu. 


\section{THESIS APPROVAL}

The abstract and thesis of Michael Coleman Howard for the Master of Arts in History were presented November 3, 1994, and accepted by the Thesis Committee and the department.

COMMITTEE APPROVALS:

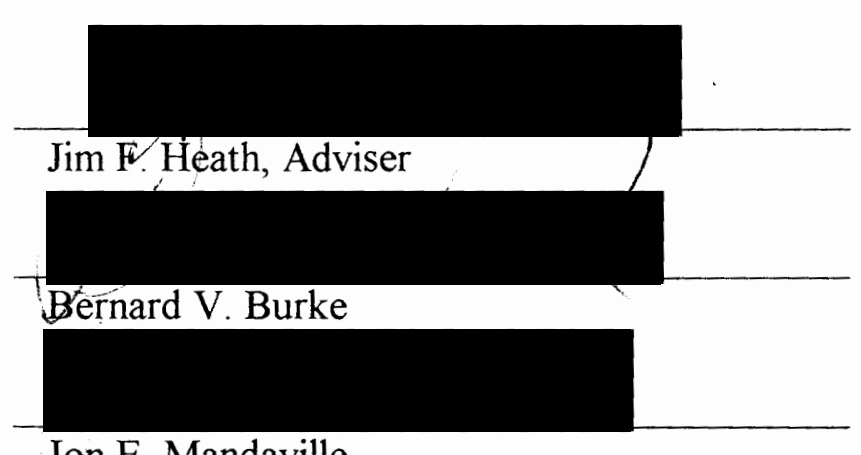
Jon E. Mandaville

DEPARTMENT APPROVAL:

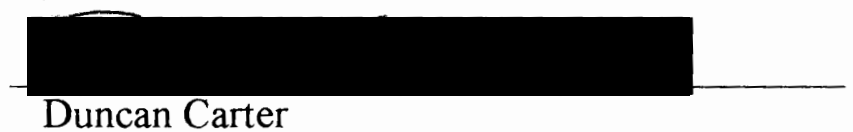

Representative of the office of Graduate studies

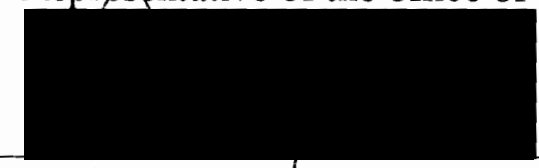

David A. Johns $\phi$ n, Chair

History Depatoment

$* * * * * * * * * * * * * * * * * * * * * * * * * * * * * * * * * * * * * * * * * * * * * * * * * * * * * * * * * * * * * * * * * * * *$

ACCEPTED FOR PORTLAND STATE UNIVERSITY BY THE LIBRARY

by

on 98 decembit 1994 


\section{ABSTRACT}

An abstract of the thesis of Michael Coleman Howard for the Master of Arts in History presented November 3, 1994.

TITLE: $\quad$ Oregon's Marines: A Regional History of the United States Marine Corps

The history of the United States Marine Corps in Oregon, and of the many Oregonians who have served as Marines, is a unique story which has never been told.

This thesis examines United States Marines from the state of Oregon and activities by Marines in the state. It covers the Oregon Marine experience from its start in 1841 through the Gulf War conflict of 1991 to the present.

From 1838 to 1842 , Lieutenant Charles Wilkes, United States Navy, led a remarkable exploration and scientific expedition around the world. In 1841, Wilkes visited the Pacific Northwest, and accompanying him aboard his flagship, the USS Vincennes, was Quartermaster Sergeant Marion A. Stearns and thirty-two other United States Marines. Stearns set a sound leadership example for both his Marines and those of the future as he landed from the sea and explored inland territory ranging from Puget Sound, to the Cascades, the Columbia River, and the Willamette Valley. Stearns' Marine detachment from the USS Peaceck even managed to survive their shipwreck upon the 
Columbia River bar. Oregon had thus begun her unique military heritage with respect to the United States Marine Corps.

From this event in 1841, the one hundred and fifty year history of United States Marines in Oregon continued.

In 1846, on the eve of the Mexican War, a Marine officer, First Lieutenant Archibald H. Gillespie, delivered a secret presidential message from James K. Polk to explorer John C. Fremont at Klamath Lake. Later, Marines from Union warship detachments visited Astoria and Portland during the Civil War. In 1898, at the Battle of Manila Bay, Private Charles C. Schroeder of Oak Grove, fought aboard the USS Olympia with Commodore George Dewey. World War I and World War II found Oregon contributing a diverse and dedicated group of Marines who served valiantly in combat against German and Japanese forces. During the long Cold War with the Soviet Union, the wars in Korea and Vietnam exhibited a continuation of faithful Marine service by Oregonians. And in Operation Desert Shield and Desert Storm of 1991, Marines from Oregon continued as their forefathers had before them to honorably serve, sacrifice, and quietly return home.

Their record of courage and professionalism are an important but little known part of Oregon's rich history. 
OREGON'S MARINES: A REGIONAL HISTORY

OF THE UNITED STATES MARINE CORPS

by

MICHAEL COLEMAN HOWARD

A thesis submitted in partial fulfillment of the requirements for the degree of

MASTER OF ARTS

in

HISTORY

PORTLAND STATE UNIVERSITY

1994 
TABLE OF CONTENTS

PAGE

ACKNOWLEDGEMENTS $\ldots \ldots \ldots \ldots \ldots \ldots \ldots \ldots \ldots \ldots$ i

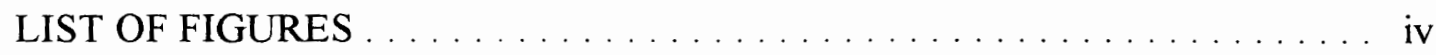

CHAPTER

I INTRODUCTION $\ldots \ldots \ldots \ldots \ldots \ldots \ldots \ldots \ldots \ldots \ldots$

II MARINE ORIGINS AND THEIR LANDING IN OREGON $\ldots \ldots 8$

III SEA DUTY, RECRUITING, AND ESTABLISHMENT

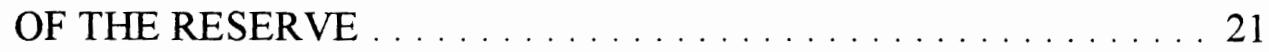

IV WORLD WAR I AND THE OREGON RESERVE . . . . . . . 48

V WORLD WAR II: THE SUPREME TEST $\ldots \ldots \ldots \ldots \ldots \ldots \ldots 74$

VI KOREA, THE CHOSIN FEW, COLD WAR . . . . . . . . . . 160

VII VIETNAM AND COLD WAR VICTORY ........... 202

VIII GULF WAR TRIUMPH AND THE NEW WORLD ORDER . . . . 219

SELECTED BIBLIOGRAPHY . . . . . . . . . . . . . . . . 264

APPENDICES .................................. 276 


\section{ACKNOWLEDGEMENTS}

"Professor Samuel Eliot Morrison has advised young historians to remember only that they have a story to tell and that the only way to tell it is to write."

William P. McCahill, Colonel USMCR The Marine Corps Reserve, A History Public Affairs Unit 4-1, HQMC, 1966

"How vain it is to sit down to write when you have not stood up to live."

Thoreau

I have sat down to write because of others I have served with . . those fellow Marines before me who have stood up to live, serve, and sacrifice. This is a history which had not been told, and I felt a strong obligation to record it to the best of my ability. This regional history of the United States Marine Corps is my own. I have attempted to be objective, but must remind the reader that this is a story, it is certainly not the story. The complex research on this work has convinced me more than ever that history is an art and not a science. As such, I accept full responsibility for any and all inaccuracies found in it and ask the reader to be patient with some of my expressed personal opinions.

I would like to acknowledge the grateful assistance and patience of several key individuals. To my wife Lynn, a special thank you for being there, willing to help discuss or edit at any given time. To my daughters Jessica, Rachel, and Meredith, a special thank you for helping your Dad in everything from how to fully utilize the computer, to 
keeping the house quiet, to "chilling out" sessions of soda, popcorn, and classic old movies! To my son Nathan, who has gently reminded me to trust in the sovereignty of God. To Jim Heath, my mentor and friend, for motivating and nurturing me by his love of the Lord, history, and service to others. He reminded me that the world is full of too many six hundred page books, on two hundred page topics, by fifty page authors! To Gordon Morgan, President of the Oregon/Columbia River Chapter of the First Marine Division Association and Tom Green, President of the Oregon Chapter of the Chosin Few, fellow Marines who took me under their wings like a son and introduced me to the Oregon Marine network system. They gave new meaning to the saying: "Marines take care of their own."

This local Oregon Marine network system of retired and former Marines was essential in filling in crucial historical gaps and providing valuable primary sources. I circulated what I called my: "Oregon Marine History Survey," with a goal of getting one such survey to every Marine (or his surviving family) in Oregon. I identified and met with many of these veterans, conducting and recording oral interviews on tape, while taking notes. Through their recollections, photographs, letters, citations, articles, clippings, and other documents, I was able to make progress in putting together the individual pieces of the large puzzle.

This has become a real labor of love, meeting with these gentlemen over lunch, in their homes, at group meetings, in museums and libraries, or in various Veterans' Administration hospitals. I felt privileged to be hearing and recording firsthand their 
special recollections from Americn history. It was sad to reflect upon just how many other fascinating stories had been lost over time. History is fragile.

I would also like to thank Dick Matthews, fellow aspiring historian and another kindred spirit of Jim Heath, for his superb research and writings on the Marine Barracks at Klamath Falls. Organizations such as the Marine Corps Historical Center at the Navy Yard in Washington, D.C., the Columbia Maritime Museum and the Clatsop County Historical Society, Astoria, Oregon, the Pioneer Museum, Tillamook, Oregon, and the Oregon Historical Society, Portland, Oregon were extremely helpful in allowing me to use their archives. A special and final note of gratitude and inspiration must be made in memory of Colonel Robert S. Mayo, the original 6th Engineer Battalion executive officer and historian during the Battle of Okinawa in 1945. His rich and highly professional written history has set a personal example to me. And lastly to Mary Morgan, devoted Marine wife of Gordon, who lovingly typed and edited this manuscript.

"In your fair minds let this acceptance take."

$$
\text { Shakespeare, Henry } \mathrm{Y}
$$




\section{LIST OF FIGURES}

FIGURE

PAGE

1. Columbia Rediviva . . . . . . . . . . . . . . . . . . . . 4

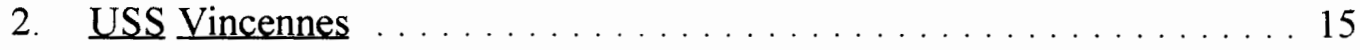

3. Late 1830 's era Marine . . . . . . . . . . . . . . . . . . 18

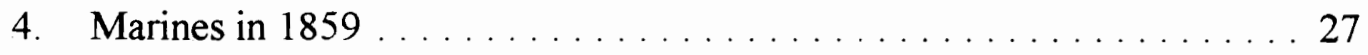

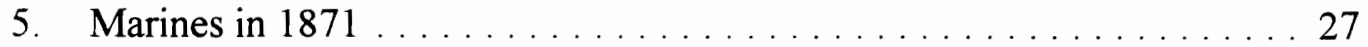

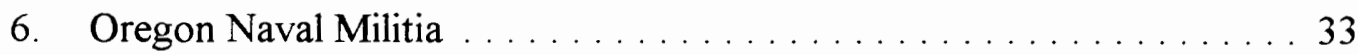

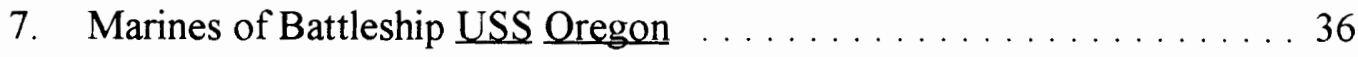

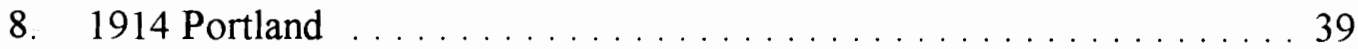

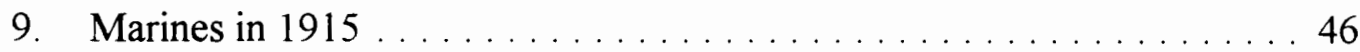

10. Albert G. Skelton . . . . . . . . . . . . . . . . . . 60

11. Cecil Key . ............................. 60

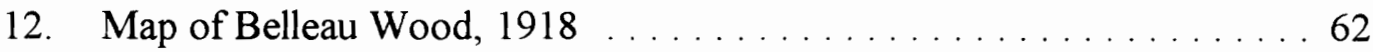

13. Marine attack at Belleau Wood $\ldots \ldots \ldots \ldots \ldots \ldots \ldots \ldots \ldots$

14. Tactical map of Belleau Wood ....................... 64

15. 2nd Battalion, 6th Marines ...................... 65

16. Marine guarding U.S. Mail . . . . . . . . . . . . . . . . . . . . . . 69

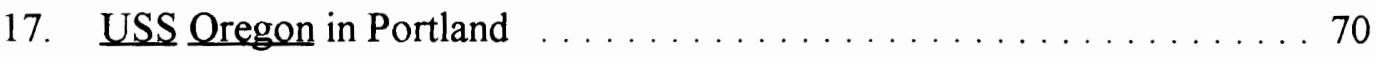


18. Marine Reserves with USS Oregon $\ldots \ldots \ldots \ldots \ldots \ldots$

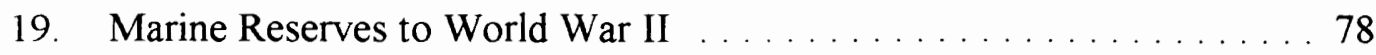

20. Harry H.W. Niehoff, Bremerton . . . . . . . . . . . . . . . . 80

21. Marines at Navy Yard, Bremerton ................ 81

22. Marine Barracks, Puget Sound ..................81

23. Oregon Marines, Pearl Harbor . . . . . . . . . . . . . . . 83

24. Camp Salt Lake, Oahu, $1941 \ldots \ldots \ldots$

25. Pearl Harbor, 7 December $1941 \ldots \ldots \ldots \ldots \ldots$

26. Marine Barracks, Pearl Harbor . . . . . . . . . . . . . . . . 85

27. Elmer S. Drake Jr., USS Oregon ... . . . . . . . . . . . . . . 89

28. E.S. Drake Jr., Wake Island Marines . . . . . . . . . . . . . . . 89

29. William F. Bostick, Prior to Wake ... . . . . . . . . . . . . 91

30. W.F. Bostick, Japanese POW ... . . . . . . . . . . . . . 91

31. Map of Guadalcanal, $1942 \ldots \ldots \ldots \ldots \ldots$

32. Marion E. Carl with Nimitz, $1942 \ldots \ldots \ldots \ldots$. . . . . . . 97

33. Marion E. Carl, $1943 \ldots \ldots \ldots \ldots \ldots \ldots \ldots \ldots$

34. John D. Harshberger ... . . . . . . . . . . . . . . . . . . 99

35. Marine PV-1 Ventura Night Fighter . . . . . . . . . . . . . . 99

36. Gordon W. Morgan . . . . . . . . . . . . . . . . . . . . . . . 102

37. Emil E. Huxel with Sherman Tank, 1943 . . . . . . . . . . . . . . . . . 104

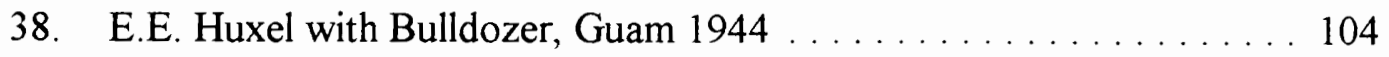


39. Naval Air Station Tongue Point . . . . . . . . . . . . 107

40. Marine Barracks Astoria . . . . . . . . . . . . . . . . . . . . . 107

41. Marines, Naval Air Station Tillamook . . . . . . . . . . . . . . . . . 109

42. Marines, 10 November 1943, Tillamook .............. 109

43. Aerial view, NAS Tillamook $\ldots \ldots \ldots \ldots \ldots \ldots \ldots \ldots \ldots \ldots$

44. Blimps of ZP-33, NAS Tillamook ................. 111

45. Marine Barracks Klamath Falls $\ldots \ldots \ldots \ldots \ldots \ldots \ldots \ldots \ldots$

46. Colonel Dubel USMC, Klamath Falls . . . . . . . . . . . . . . . 114

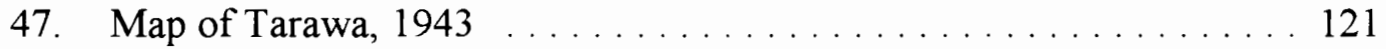

48. Red Beach 3, Tarawa ........................ 121

49. Dixie Turner McKendrick $\ldots \ldots \ldots \ldots \ldots \ldots \ldots \ldots \ldots \ldots \ldots$

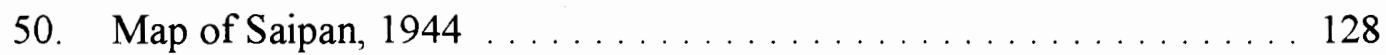

51. Japanese Marines, Saipan . . . . . . . . . . . . . . . . . . . . . . 129

52. Marine Engineers, Saipan, 1944 . . . . . . . . . . . . . . . . . . 129

53. Map of Peleliu, $1944 \ldots \ldots \ldots \ldots \ldots \ldots \ldots \ldots \ldots \ldots \ldots \ldots \ldots$

54. Arthur J. Jackson with Truman, $1945 \ldots \ldots \ldots \ldots \ldots \ldots \ldots \ldots$

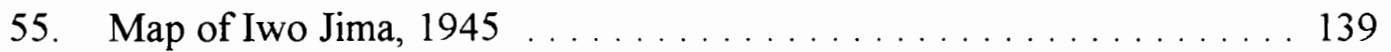

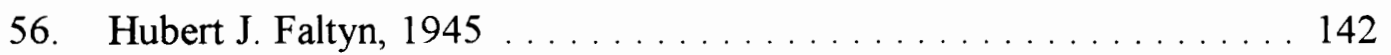

57. Howard S. Brandon Jr. . . . . . . . . . . . . . . . . . . . . . . . 145

58. Map of Okinawa, $1945 \ldots \ldots \ldots \ldots \ldots \ldots \ldots \ldots \ldots \ldots \ldots$

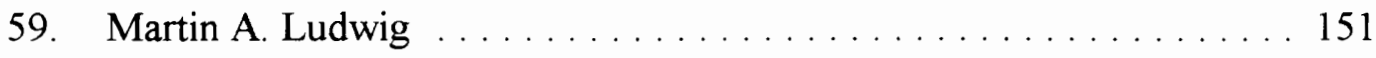


60. M.A. Ludwig, Okinawa, $1945 \ldots \ldots \ldots \ldots \ldots \ldots \ldots \ldots \ldots \ldots$

61. Robert S. Mayo, Okinawa, $1945 \ldots \ldots \ldots \ldots \ldots \ldots \ldots \ldots$

62. Nago, Okinawa Bailey Bridge $\ldots \ldots \ldots \ldots \ldots \ldots \ldots \ldots \ldots$

63. Marine Engineer, Okinawa, $1945 \ldots \ldots \ldots \ldots \ldots \ldots \ldots \ldots \ldots$

64. Frank W. Kyser, Okinawa, $1945 \ldots \ldots \ldots \ldots \ldots$

65. Marine Reserve Center, Swan Island $\ldots \ldots \ldots \ldots \ldots \ldots \ldots \ldots$

66. Portland USMC/USMCR Staffs, $1947 \ldots \ldots \ldots \ldots \ldots \ldots \ldots$

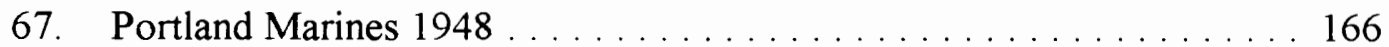

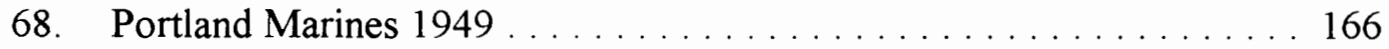

69. Sketch of Salem USMCR Center, $1948 \ldots \ldots \ldots \ldots \ldots \ldots \ldots$

70. Salem Reserve Center, 1949 . . . . . . . . . . . . . . . . 167

71. Salem Marines, $1947 \ldots \ldots \ldots \ldots \ldots \ldots \ldots \ldots \ldots \ldots$

72. Marines at Salem Train Depot $\ldots \ldots \ldots \ldots \ldots \ldots \ldots \ldots$

73. Oregon Marines: Train to Camp Pendleton . . . . . . . . . 170

74. 17th Engineers: Bridging . . . . . . . . . . . . . . . . . . . . 170

75. Portland Marines: Marksmanship, $1950 \ldots \ldots \ldots \ldots \ldots \ldots \ldots 17$

76. Marines: Korean Activation, $1950 \ldots \ldots \ldots \ldots \ldots \ldots \ldots \ldots$

77. Marine Bulldozer in Korea, $1950 \ldots \ldots$. . . . . . . . . . . . . . . 181

78. Oregon Marines, Korea, $1950 \ldots \ldots \ldots \ldots \ldots \ldots \ldots \ldots \ldots$

79. Oregon Marines, Korea, $1950 \ldots \ldots \ldots \ldots \ldots \ldots \ldots \ldots$

80. Map of Chosin Reservoir, $1950 \ldots \ldots \ldots \ldots \ldots \ldots \ldots \ldots . \ldots \ldots$ 
81. Thomas G. Green, Korea, $1950 \ldots \ldots \ldots$. . . . . . . . . . . . . 187

82. Associated Press Map, Korea . . . . . . . . . . . . . . . . . . . . . . . . . . . . 189

83. Oregon Marine 155 Howitzer, $1952 \ldots \ldots \ldots \ldots . \ldots \ldots \ldots$

84. Miss Marine Corps Reserve, 1953 . . . . . . . . . . . . . . . . . . . . 194

85. Oregon Marine BAR Qualification . . . . . . . . . . . . . 195

86. Oregon Marines, Amphibious Landing . . . . . . . . . . . . . . . . . . 196

87. Portland Marine Formation, 1955 . . . . . . . . . . . . . . . . . . . 197

88. Portland Marine Departure, $1955 \ldots \ldots \ldots$. . . . . . . . . . . . . . 197

89. Oregon Marine TD-18 Bulldozer . . . . . . . . . . . . . . . . . . . . 199

90. Oregon Marine 8230 Bulldozer . . . . . . . . . . . . . . . . . . . . . . . 199

91. Map of I Corps, Vietnam . . . . . . . . . . . . . . . . . . . . . . . . . . . 204

92. Gary W. Martini . . . . . . . . . . . . . . . . . . . . . 206

93. I Corps Tactical Zone, Vietnam, $1967 \ldots \ldots \ldots$. . . . . . . . . . 208

94. William E. O'Connor, $1967 \ldots \ldots \ldots \ldots \ldots$

95. Operation Buffalo, Vietnam, $1967 \ldots \ldots \ldots \ldots \ldots \ldots \ldots$

96. Alfredo J. Arguedas . . . . . . . . . . . . . . . . . . . . . 212

97. P.E. "Gunny" Brandon . . . . . . . . . . . . . . . . . . . . . . . . . 215

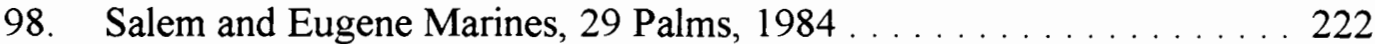

99. Salem and Eugene Marines, Yakima, $1986 \ldots \ldots \ldots \ldots . \ldots \ldots 23$

100. A.J. Arguedas and Author, $1987 \ldots \ldots \ldots \ldots \ldots \ldots$

101. Marine EA-6B over Kuwait City, $1991 \ldots \ldots \ldots \ldots$ 


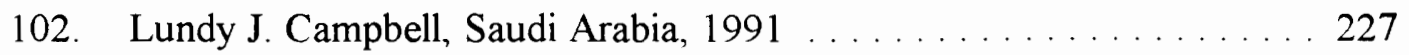

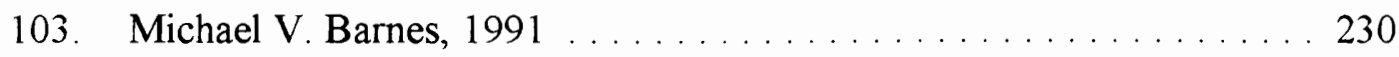

104. Oregonian, 30 November $1990 \ldots \ldots \ldots \ldots \ldots \ldots \ldots$

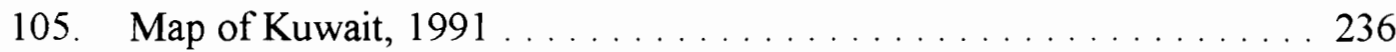

106. Marine Bunker, Saudi Arabia, $1991 \ldots \ldots \ldots \ldots \ldots \ldots$

107. Marine D-7 Bulldozer, Kuwait, $1991 \ldots \ldots \ldots \ldots \ldots \ldots$

108. Oregon Marine with Iraqi Mine . . . . . . . . . . . . . . . . . 240

109. Portland Marines in Kuwait, $1991 \ldots \ldots \ldots \ldots$. . . . . . . . . . . . 240

110. Demolitions in Kuwait, $1991 \ldots \ldots \ldots$. . . . . . . . . . . . . . . . 247

111. Iraqi T-72 Tank, $1991 \ldots \ldots \ldots \ldots \ldots \ldots \ldots \ldots \ldots$

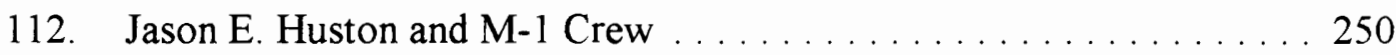

113. J.E. Huston with $\mathrm{T}-55 \ldots \ldots \ldots \ldots \ldots \ldots \ldots \ldots \ldots$

114. Marine Ground Offensive, Kuwait . . . . . . . . . . . . . . . 252

115. Oregon Marines with Bulldozers, $1991 \ldots \ldots \ldots \ldots \ldots \ldots$

116. Desert Sapper, 29 Palms, $1991 \ldots \ldots \ldots \ldots \ldots \ldots \ldots$

117. Jordan Covered Bridge, Stayton _. . . . . . . . . . . . . . . . 257

118. Oregon Marines, Camp Rilea, $1993 \ldots \ldots \ldots \ldots \ldots$

119. Civil War Fort Stevens, $1992-93 \ldots \ldots \ldots \ldots \ldots \ldots$

120. Oregon Marines at Fort Stevens . . . . . . . . . . . . . . . 258

121. Oregon Marine Amphibious Landing . . . . . . . . . . . . . . . . . 259

122. Oregon Marine Helicopter Operations . . . . . . . . . . . . . . . 259 


\title{
CHAPTER I
}

\section{INTRODUCTION: THE OREGON MARINE LEGACY}

\author{
"Those Marines of whom I soe oft have wrote you, \\ behaved themselves stoutly. "1
}

Aide to Lord Arlington, Battle of Solebay, 1672

First use of english word: "Marines"

"The Marines' service is amphibious; they must know how to behave by sea as well as by land. ${ }^{2}$

Sir William Yonge, British Parliament Debate, 27-28 November 1739

"Resolved, that two Battalions of Marines be raised . . that they be distinguished by the names of the first and second battalions of American Marines. ${ }^{13}$

Continental Congress Resolution of 10 November 1775

'J. L. Moulton, The Royal Marines, (Eastney, Great Britain, 1981), p. 3.

${ }^{2}$ Alfred J. Marini, "Parliament and the Marine Regiments, 1739" in Assault From The Sea, by Merrill L. Bartlett (Annapolis, 1983), p. 45.

${ }^{3} J$. Robert Moskin, The U.S. Marine Corps Story, (New York, 1977), p. 11 . 
The United States Marine Corps serves as America's amphibious force-inreadiness. This mission stems from America's position as a maritime nation with worldwide interests. The United States had Marines serving in her defense even before her birth as a nation. With the formal establishment of the Marines by the Continental Congress on 10 November 1775 , the leaders of the emerging country acknowledged an important fact: that as a maritime nation dependent upon commercial trade on the high seas, protection of property necessitated both a Navy and a Marine Corps. This had been accepted years prior when many of the colonies formed their own naval forces.

Throughout the years, the United States has continued to be well served by her Marines. Throughout the world, whether on land, at sea, or in the air, Marine readiness and versatility have been appreciated by Congress and the public. History and geography are by tradition and mission important to Marines and the state of Oregon comprises a little known part of this tradition. The primary objective of this work is to tell a story. There are many Marines who as native born or transplanted Oregonians know parts of this story, but few if any know just how old and rich a history it is. The Oregon public knows almost nothing of it.

Most historians of the American Northwest readily acknowledge that the initial European exploration of Oregon and the surrounding region was maritime in nature. The United States was a relatively late starter in the international game of discovery and acquisition, but made up for in enthusiasm and luck for what was lacking in power and experience. Ability, common sense, and determination on the part of political, 
commercial, and military leaders, coupled with a relentlessly growing and westward moving population, were the essential factors in securing the Pacific Northwest for the young nation.

In May 1792, after it had been bypassed by several Europeans, American merchant captain Robert Gray discovered the Columbia River and charted its entrance for the first time. The United States staked its claim to Oregon with this event. Little more than a decade later, in December 1805, at the direction of President Jefferson, United States Army officers Captain Meriwether Lewis and Second Lieutenant William Clark completed the first half of their famous transcontinental trip. They established their winter headquarters at Fort Clatsop, just south of the mouth of the Columbia River. In March 1811, men of John Jacob Astor's Pacific Fur Trading Company, under Duncan McDougall, founded a trading post and fort near the mouth of the Columbia River. They named the settlement Astoria.

Thirty years later, in July 1841 , Lieutenant Charles Wilkes, United States Navy, led his remarkable exploration and scientific expedition of 1838-1842 to the Pacific Northwest. This further provided the United States with a strategic link to the area. Accompanying Wilkes aboard his flagship, the USS Vincennes, was Quartermaster Sergeant Marion Albert Stearns of the United States Marine Corps ${ }^{4}$. Under his command and responsibility were the squadron's detachment of thirty-three United States

${ }^{4}$ Robert Debs Heinl, Jr., Soldiers of the Sea, (Annapolis, 1962), p. 43. 


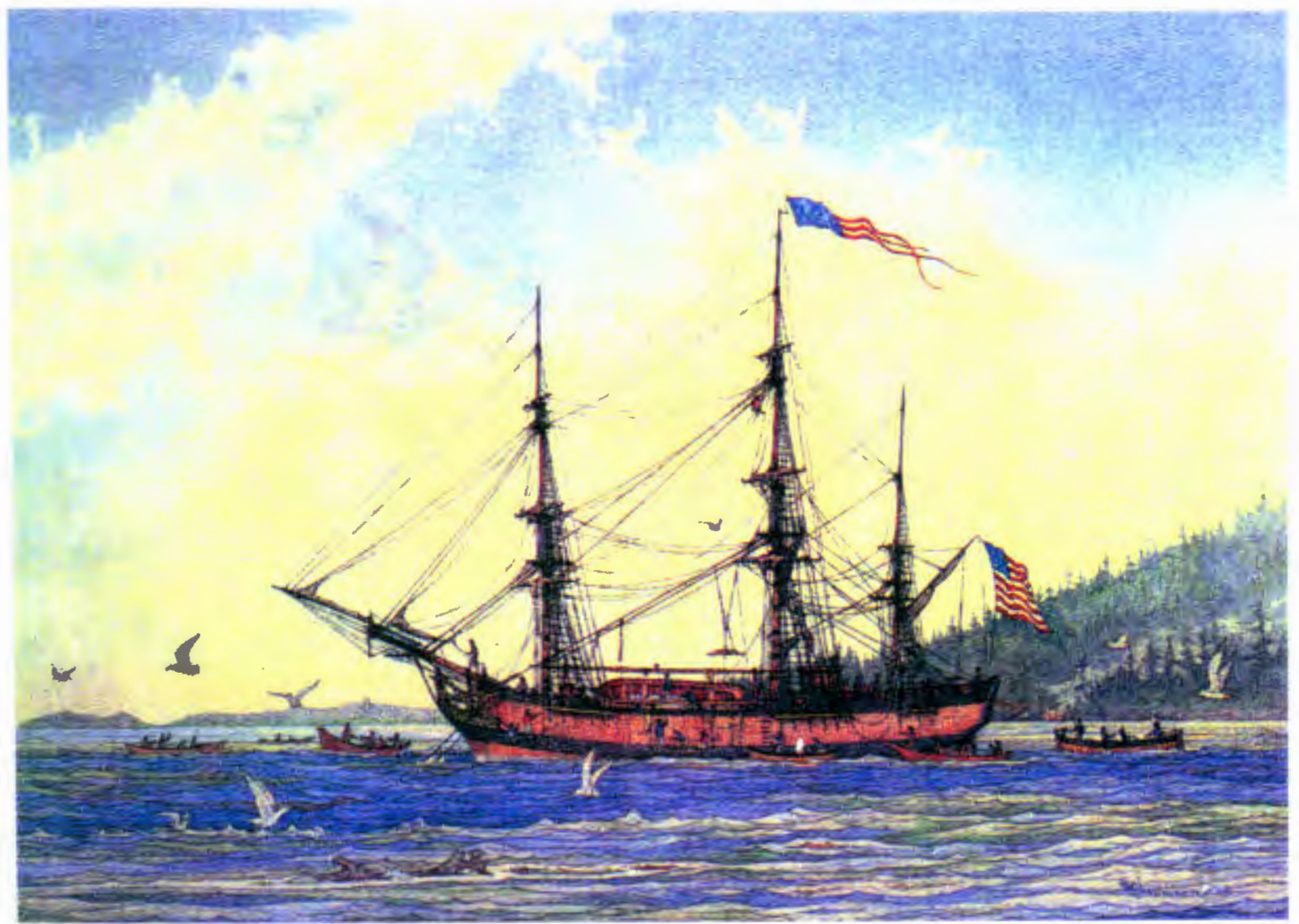

Figure 1: "Ship Columbia Rediviva of Boston, Capt.

Robt. Gray, anchors off Chinook on the Columbia River, 19 May 1792" by Hewitt Jackson (1965)

Edmund Hayes, Sr., Collection, Oregon Historical Society 
Marines ${ }^{5}$. These were the first Marines not only to visit Oregon, but to also land on Tarawa, Wake, and Makin Islands, exactly a century before the Japanese attack on Pearl Harbor. On this rather minor Marine and Oregon historical note, an important tradition began: the start of a special bond between a land and a unique group of men. Oregon had begun her unique military heritage with respect to United States Marines.

Sergeant Stearns, in the best Marine tradition, set a positive example during the Wilkes Expedition for those men and women who would later serve as Marines in and from Oregon. This tradition experienced slow but steady growth. It culminated over a century later during World War II and the Vietnam War, when two Marines from Oregon earned America's highest honor for heroism under fire: the Congressional Medal of Honor. One was killed in action while saving the lives of his fellow Marines. Examples of other Oregon Marines providing valiant service to their nation are reflected in the award of such medals as the Navy Cross, Silver Star, and the Purple Heart. These Oregon Marine sacrifices represent some of the most honored geographical names in American and Marine Corps history: Belleau Wood, Guadalcanal, Tarawa, Saipan, Peleliu, Iwo Jima, Okinawa, Inchon, and the Chosin Reservoir. These sacrifices are also represented by obscure names such as Binh Son and Dai Do from America's most unpopular war in Vietnam, in addition to the recent Gulf War in Saudi Arabia, Kuwait, and Iraq.

${ }^{5}$ Moskin, The U. S. Marine Corps Story, p. 60. 
This is the story of Marines in Oregon from the Wilkes Expedition of 1841, to Operation Desert Storm in the Gulf War of 1991. It encompasses the years of development with a young nation and a young state; years of routine ship visits, governmental apathy and neglect, funding and manpower shortages; years of widespread duties, national responsibilities and challenges; lessons in readiness learned by some from the Civil War and Spanish-American War; struggles in doctrine, direction, and dollars; the establishment of a recruiting presence and Reserve; World War I and the "come as you are" effort; maintaining during the depression; explosive growth; World War II and the triumph of doctrine in the face of a determined enemy; downscaling and the crisis of Korea; vindication of the Marine Reserve program in the Korean War; the painful experience of Vietnam; more Cold War years of widespread duty, followed by the triumph of Desert Storm and the further validation of the Marine Corps Reserve program

Throughout all of this, Marines in general and those serving in Oregon in particular, continued in the long established Corps tradition to "take care of their own." Their story includes the history of what is currently the largest battalion in the Marine Corps: the 6th Engineer Support Battalion, which is headquartered in Portland, and also represented by a combat engineer line company in Salem, and a bridge company in Eugene. No other United States Marine Corps unit has enjoyed such a long and rich history in Oregon. This story also includes the story of the Marine Corps Recruiting Station, Portland, and spreads throughout the state to cover its many substations. The 
story also includes the World War II barracks and detachments at Astoria, Klamath Falls, and Tillamook, and the Marine Corps Air Facility at Corvallis. It is also at times, a story of Oregon's individual Marines from across the state. Whether native born or transplant, they considered "home" to be Oregon. 


\section{CHAPTER II}

\section{MARINE ORIGINS AND THEIR LANDING IN OREGON}

"There shall be raised and organized a Corps of Marines. . . "6

Reestablishment of USMC, Act of Congress, 11 July 1798

"I felt that the land belonged to my country, that we were not strangers on the soil. It is very probable that the countrywill become united with Oregon, with which it will perhaps form a state that is destined to control the destinies of the Pacific. "'

Lt. Charles Wilkes USN Journal, 1841

". . . and the invaluable Sergeant of Marines, the black-eyed, bright-faced (Marion) Albert Stearns, once a fancy dyer in Massachusetts, now a master of both keel and saddle. ${ }^{18}$

William Stanton

Chronicler, Wilkes Expedition

${ }^{6}$ James C. Flanigan, The Oregonian, February 9, 1986, p. 17.

${ }^{7}$ William Stanton, The Great United States Exploring Expedition of 18381842, (Berkeley, California, 1975), p. 259.

${ }^{8}$ Robert Debs Heinl, Jr., Soldiers of the Sea, (Annapolis, Maryland, 1962), p. 3. 
This is the story of a special breed of men who are as old as war at sea. The exact origin of marines as seagoing soldiers or naval infantry has been lost in antiquity. Since the dawn of naval warfare however, there have been roughly two distinct types of men who have gone to sea: the rowers and the warriors. Though the names and terminologies have changed, these two diverse groups of naval personnel translate now into the categories of sailors and marines. The word "marine" itself stems from the Latin "marinus," meaning "related to the sea." The Marine mission associated with amphibious capability is based on the Greek word "amphibion," which literally means, "living a double life." 9

In the epic Iliad, Homer spoke of Greek warriors in armor, who, distinct from the loin clad sailors, positioned themselves on the forward decks so as to seize a beachhead on the Trojan shore ${ }^{10}$. At least as far back as a thousand years before the birth of Christ, the Egyptian fleet of Ramses III was divided into sailors and warriors who successfully repelled hordes of Philistine naval invaders from the north ${ }^{11}$. When Themistocles mobilized Athens, one of his first decrees was to enlist twenty "ephibatae" or "heavily armed sea soldiers," per ship ${ }^{12}$. At the battle of Salamas in $480 \mathrm{BC}$ the combined Athenian and Corinthian navies defeated the mighty Persian fleet with the vital help of

${ }^{9}$ A. Lukeman, Guidebook for Marines, (Quantico, Virginia, 1990), p. 1.

${ }^{10}$ Moskin, The U.S. Marine Corps Story, p. 11.

${ }^{11}$ Ibid., p. 12.

${ }^{12}$ Heinl, Soldiers of the Sea, p. 3. 
these warriors ${ }^{13}$. In $260 \mathrm{BC}$, at the Battle of Mylae, Rome was able to triumph over the superior naval power of Carthage through the tactic of placing a powerful 120 man force of "milites classiarii" or "soldiers of the fleet," together with their specialized boarding ramp, aboard each of her warships ${ }^{14}$. This ensured Roman supremacy in the Mediterranean for centuries to come.

Though these early warriors shared many of the same occupational characteristics of both sailors and soldiers, they were called upon to perform a unique mission. In this they were neither sailors nor soldiers. They were "soldiers of the sea" or marines. Those who failed to understand this unique mission and persisted in simply placing regular infantry aboard ships for a prolonged period, as in the case of Spain and her Armada in 1588 , learned a nasty lesson. ${ }^{15}$ It took a good deal more to make a marine than a soldier immune to seasickness. Nor could sailors historically be reliably counted upon to perform their regular duties and also demonstrate proficiency in close combat or assault landing operations. This was a bitter lesson learned by the British at Gibraltar in 1704 , where despite the success of their "Queen Anne's Marines" in capturing the fortress, sailors serving in the landing force suffered a disproportionately high casualty rate ${ }^{16}$.

${ }^{13}$ Charles R. Smith, Marines in the Revolution, (Washington, D.C., 1975), p. 1.

${ }^{14}$ Ibid., p. 1.

${ }^{15}$ David Eggenberger, An Encyclopedia of Battles, (New York, 1967), p. 414.

${ }^{16}$ Bartlett, Assault from the Sea, p. 43. 
On occasion, even into the 19th century, many a ship's captain was thankful to have loyal marines aboard who could put down a mutinous crew. Within the "pressed" crews of Britain's Royal Navy, the ratio of marines to sailors was standardized at approximately one marine for every four sailors ${ }^{17}$, which also worked out to roughly a marine for each cannon carried aboard ship. ${ }^{18}$ This same approximate ratio would later be adopted by the United States.

The origin of Britain's Marines, who were given the title "Royal" from King George III in 1802, traces its founding back to 28 October 1664, during the Dutch Wars. They would later set the example in both mission and organization for America's first Continental Marines.

On 13 October 1775, the Continental Congress established the Continental Navy. Within days, on 10 November 1775, John Adams sponsored a resolution, enacted by Congress, which also established the Continental Marines. At the height of the Revolutionary War, in 1779 , a peak of 124 officers and some 3,000 men were serving as United States Marines. The story of United States Marines in the American Revolution was one of both heroism and amateurism. American Marines, whether Continental or United States, Colonial or State, privateer or ad hoc recruits, came from a seafaring, coastal people eager to fight for the cause of liberty in the manner they knew

${ }^{17}$ Anthony Preston, Navies of the American Revolution, (Englewood Cliffs, New Jersey), p. 414.

${ }^{18}$ Mark Mayo Boatner III., Encyclopedia of the American Revolution, (New York, 1974), p. 674. 
best. These first Marines had no established traditions, no cherished esprit de corps, no formal schools, organization or doctrine, yet they made up for in enthusiasm and perseverance for what they lacked in formal training and experience.

The original resolution of Congress embodied the proper idea of a corps of Marines from which battalions could be formed for both expeditionary service and ship's detachments. This central focus was lost as the young nation struggled for survival, and insufficient resources, lack of coordination, extreme distances, and slow communications all took their toll. By the end of the Revolutionary War, the mere existence of active American naval forces in the face of the world's most powerful navy was a victory in itself.

In 1783, the Treaty of Paris brought the American Revolutionary War to a close. Almost all of the country's military forces were rapidly disbanded. By September of 1783, the last Marine officer had been discharged, and in June of 1785 , Congress authorized the sale of the last of America's warships. The real glory of the United States Marine Corps was yet to come, but the Marine reputation for service, sacrifice, and honor were there from the start.

Meanwhile, America pushed west from birth, in a drive that would eventually lead to the western coast of the continent. Oregon was to be a part of this conquest. It began when the young United States of America first staked a claim to the Pacific Northwest region. This was based on the May 1792 discovery by Captain Robert Gray, master of the Boston merchant vessel Columbia Rediviva, of the North American continent's 
second largest river. Gray named the mighty river "Columbia's River" after his ship. Europeans such as Spain's Bruno de Hezeta in August 1775, England's Captain James Cook in March 1778, France's Compte de La Perouse in June 1786 and England's Captain George Vancouver in April 1792, had all passed near the mouth of the Columbia. Gray however, on 11 May 1792, actually entered and crossed the dangerous river's bar, sailing inland some thirty miles to the vicinity of Tongue Point. His charts and soundings were soon passed on to the Spanish and British, who had no recourse but to acknowledge the American's accomplishment ${ }^{19}$. This became an early basis for America's claim to Oregon Country, the word "Ouragon" being an Indian name for the River of the West $^{20}$.

Meanwhile, the need to protect American commerce against maritime threats such as French privateers and Barbary pirates confronted Congress. In 1794, a Naval Act in response to French captures of U.S. ships, provided for six frigates and crews to include 6 Marine officers and 306 enlisted men. On 27 April 1798, the Navy Department was formally established as a U.S. response to the undeclared naval war with France. On 11 July 1798, Congress sent to President John Adams "An Act for Establishing and Organizing a Marine Corps."21 The United States Marine Corps was here to stay.

${ }^{19}$ Thomas Vaughan, "River of the West" in American History Illustrated, Volume XXVII, \#2, May/June 1992, p. 43.

${ }^{20}$ Gordon B. Dodds, The American Northwest, (Arlington Heights, Illinois, 1986), p. 18.

\footnotetext{
${ }^{21}$ Heinl, Soldiers of the Sea, p. 10.
} 
The American historical connection to Oregon Territory continued when Captain Meriwether Lewis and Lieutenant William Clark, sharing command of President Thomas Jefferson's government sponsored expedition, completed the first half of their heroic trip across the continent. They left St. Louis, Missouri, on 14 May 1804, and following first the Missouri and then the Columbia River, reached the Pacific Ocean on 15 November 1805. In December 1805, they set up winter headquarters at the mouth of the Columbia River, at Fort Clatsop, where they remained until 23 March $1806^{22}$. Roughly retracing their western path, the expedition returned east to St. Louis on 28 September 1806.

The American stake in this region continued in March 1811, when the settlement of Astoria was founded by New York merchant John Jacob Astor's Pacific Fur Trading Company. Led by Duncan McDougall, these first thirty-three American settlers landed from the merchant vessel Tonquin, and constructed a trading post and fort. Thus was established Oregon's oldest town.

In April 1841, in what would further give the United States a strategic link to the Pacific Rim, Lieutenant Charles Wilkes, of the USS Vincennes, arrived at the mouth of the Columbia River. Authorized a decade earlier during the administration of President John Quincy Adams, Wilkes commanded the crew members and scientists of the great United States Exploring Expedition of 1838-1842. This remarkable 1,392-day voyage and scientific expedition set many a precedent. Under the strong-willed, no-nonsense, daring and drive of the young Wilkes, this far-flung sea and land odyssey heralded the

${ }^{22}$ Gordon Speck, Northwest Explorations, (Portland, Oregon, 1954), p. 255. 


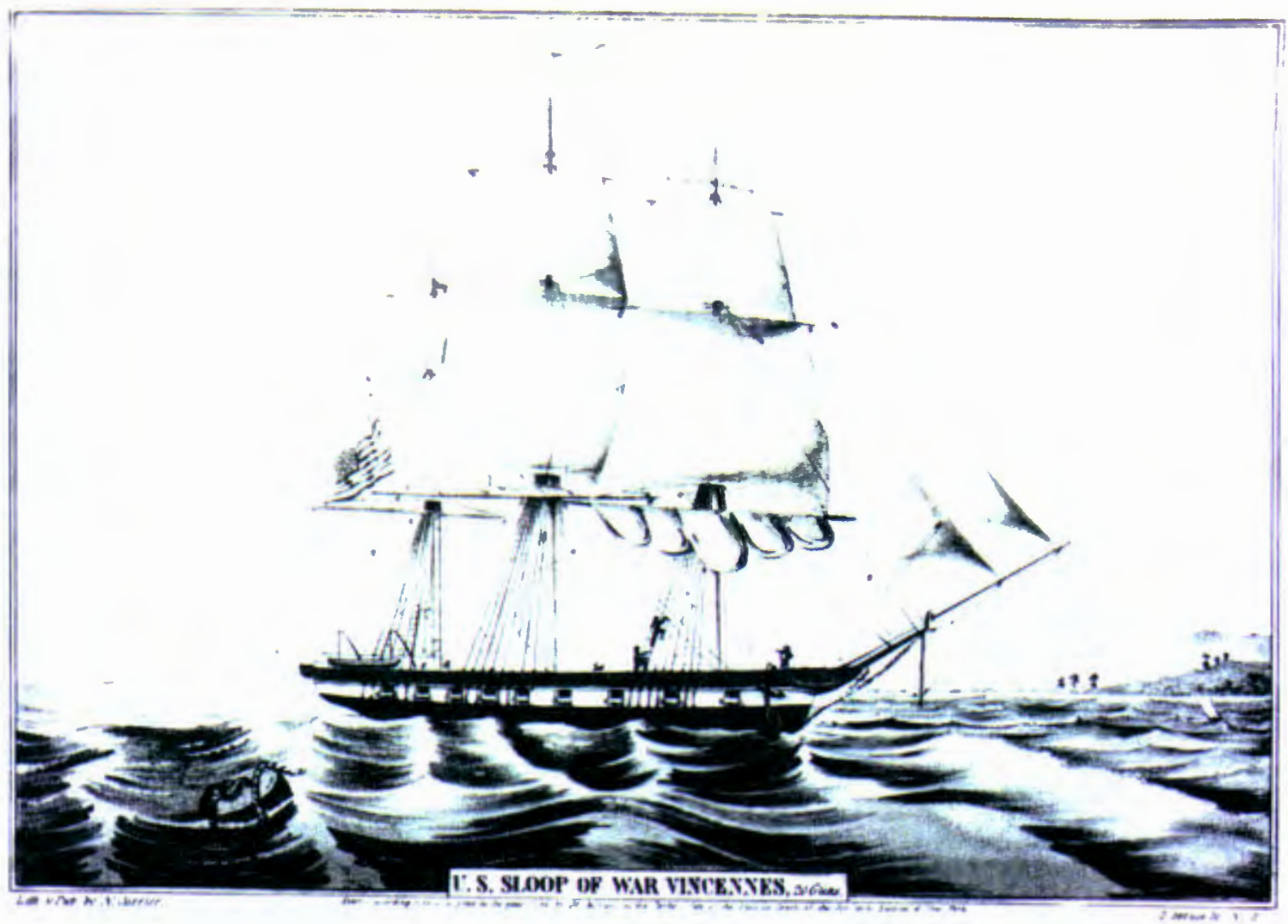

Figure 2: USS Vincennes sloop of war and flagship of the Wilkes Expedition, 1838-1842. Launched in 1826, this 700 ton ship had dimensions of $127^{\prime} \times 33^{\prime} 9^{\prime \prime} \times 16^{\prime} 6^{\prime \prime}$. Rated at 20 guns, she actually had an armament of (4) 8 inch guns, and (14) 32 pounders. She enjoyed a long and highly successful carreer, finally being sold after the Civil War in 1867. Quartermaster Sergeant Marion A. Stearns, senior Marine with the expedition's 33 man Marine detachment, was stationed aboard the USS Vincennes

United States Naval Institute photo service library 
settlement of the Oregon Territory under the American Flag. Among the milestones were the detailed and highly accurate surveys of the area, which when combined with new charts of the western region by pathfinder Captain John C. Fremont, provided the first complete map of what was to become the continental United States. Wilkes also provided official documentation of the important political efforts by settlers to form a government, firmly establishing an American presence on the eve of the great United States westward pioneer movement into the British-dominated Pacific Northwest. ${ }^{23}$

These events provided the United States with its primary claim and means by which it would later secure this region known as Oregon Territory.

For Sergeant Stearns and his Marine detachment, this was simply doing one's duty. For well over four decades, Marines had been routinely stationed aboard American warships, serving those varied duties which they had always done as "soldiers of the sea." Under the 1834 authorized reorganization, the Marine Corps stood at 59 officers and 1,224 enlisted Marines. In the case of the six ship Wilkes Expedition squadron, this involved exploring and charting Antarctica, the Fiji Islands, Samoa, the Gilbert Islands (where ironically, maps made of Tarawa by Wilkes would be consulted just over 100 years later prior to the epic Marine assault), portions of the Philippines, the Hawaiian Islands, and the Pacific Northwest.

On the morning of 28 April 1841, following passage from Oahu, Hawaii (then known as the Sandwich Islands), Wilkes, aboard the USS Vincennes, together with the

${ }^{23}$ Flanigan, The Oregonian, p. 16. 
USS Porpoise, bypassed the dangers of the Columbia River bar. Wilkes proceeded north to chart the Straits of Juan de Fuca and Vancouver Island and by 11 May 1841, the Vincennes and Porpoise arrived at Fort Nisqually, near present day Olympia. From Fort Nisqually, Wilkes launched a land expedition eastward on 19 May 1841. With it, was Sergeant Stearns of Marines. This overland party of seven conducted an extensive exploration. They crossed the Cascade Range north of Mount Rainier, proceeded eastward through Flathead country to Fort Colville at the junction of the Columbia and Clark Rivers. From here they pressed south to Fort Walla Walla, returning along the Yakima River and back across the Cascades to the Willamette Valley ${ }^{24}$. Meanwhile, Wilkes also departed Fort Nisqually on 19 May 1841, and proceeded south to Fort Astoria, with a second party. Here, he looked into the possibility of establishing coastal defenses in the Astoria area. Following this, Wilkes headed east to visit the Hudson Bay Company settlement of Fort Vancouver. From Fort Vancouver, Wilkes again sent Sergeant Stearns with a nine-man party south, overland to San Francisco. Following a route almost parallel to present day Interstate 5, they would later link up with the USS Vincennes and the rest of the squadron. Following visits to the Willamette Valley, Wilkes returned to Fort Nisqually, on Puget Sound, where he and the majority of the squadron's Marines celebrated the 4 th of July $1841^{25}$. On 17 July 1841 , Wilkes departed 46.

${ }^{24}$ Frances B. Barkan, The Wilkes Expedition, (Olympia, Washington, 1987), p.

${ }^{25}$ Ibid, p. 67. 


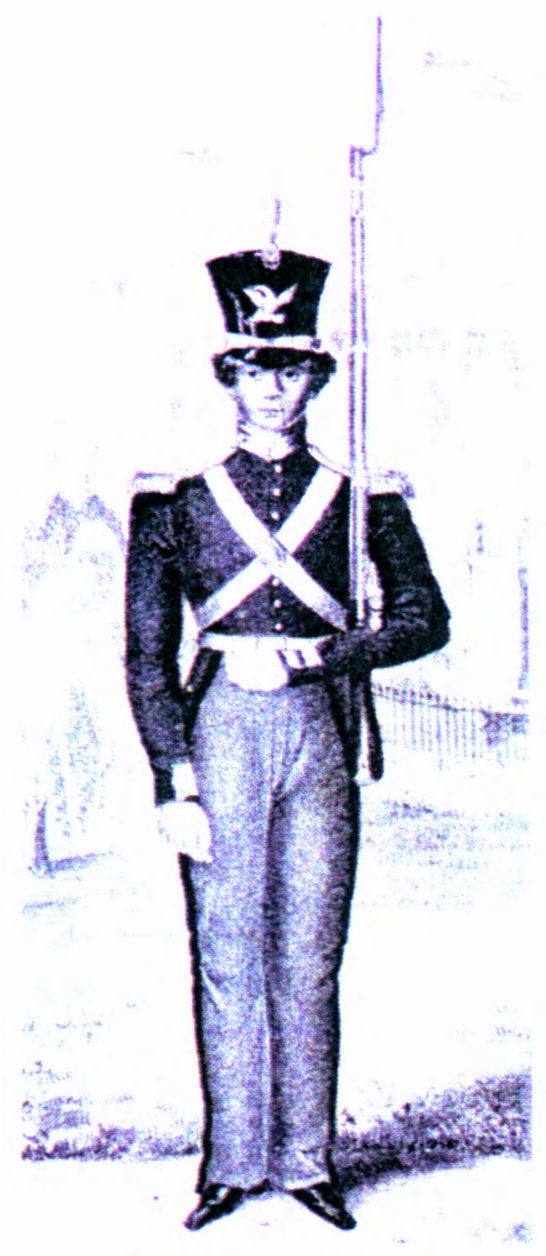

Figure 3: An enlisted United States Marine in the full dress uniform of the late 1830s to early 1840 s period. This is most probably what Quartermaster Sergeant Marion A. Stearns and his detachment of 33 Marines of the Wilkes Expedition looked like at their best.

Soldiers of the Sea by R.D. Heinl, Jr, U.S. Naval Institute, Annapolis, 1962, p. 47. 
Fort Nisqually and sailed out of Puget Sound with both the USS Vincennes and USS Porpoise. On 27 July 1841 , he received word that at approximately 1305 hours on Sunday, 18 July 1841, the USS Peacock (the first American naval vessel to make such an attempt) had been wrecked on the bar at the mouth of the Columbia River, near Cape Disappointment. All of her crew, to include Marines, had been rescued by the USS Flying Fish, which successfully crossed the bar and anchored in Bakers Bay, thus becoming the first U.S. Navy warship to enter the Columbia River. Wilkes arrived in Astoria on 7 August 1841, and soon made arrangements with Dr. John McLoughlin, chief factor of the Hudson's Bay Company, to purchase another vessel. By early September 1841 , following an extensive survey of the Columbia River, the expedition assembled in Astoria and departed for San Francisco (then known as Yerba Buena).

From San Francisco, in mid October 1841, Wilkes and his expedition conducted their homeward passage westward. On 19 December 1841, Wilkes' squadron visited Wake Island. Exactly 100 years later, a Marine battalion would be desperately defending this atoll from the Japanese, with the last Marines to surrender doing so on the atoll's Wilkes Island. From Wake, the Wilkes expedition proceeded to Manila, past Corregidor in the Philippines, to Singapore, across the Indian Ocean, around Africa's Cape of Good Hope, and north up the Atlantic. Having originally departed from Hampton Roads, Virginia, in August 1838, Lieutenant Charles Wilkes and his expedition had circumnavigated the globe (the first Americans to do so), and returned home to New York, in June 1842 . The 180 detailed maps and charts alone were deemed by the 
Secretary of the Navy as having been worth the total cost of the expedition. ${ }^{26}$ Quartermaster Sergeant Marion Albert Stearns, United States Marine Corps, had set an excellent example. In almost four years, he rounded Cape Horn, explored 1,500 miles of Antarctic coast (where "Wilkes Land" received its name), battled Fijian, Samoan, and other hostile islanders, helped chart and survey some 280 Pacific islands, endured diseases and poor food, helped map 800 miles of Pacific Northwest coast, crossed the snowy Cascades twice, traveled southward the length of the Willamette Valley, on to San Francisco Bay, and circumnavigated the globe for a total of approximately 90,000 miles traveled. Due largely to Sergeant Stearn's outstanding leadership, only four Marines lost their lives on this historic expedition.

The Wilkes Expedition, quite literally, helped put the Pacific Northwest on the United States map. The Oregon Treaty of 1846 , between the United States and Great Britain, established the 49th parallel as the common border, with Oregon becoming first a United States Territory in 1848 , and finally a state in 1859 . Due in part to the dedicated service of men such as Sergeant Stearns and his detachment of Marines, the first generation of American settlers were assisted in their westward trek to Oregon and the Pacific Northwest.

${ }^{26}$ Ross Anderson and Keith Benson, "They Put the Northwest on the Map" in The Seattle Times/Seattle Post Intelligencer, September 20, 1987, p. 4-5. 


\section{CHAPTER III}

\section{SEA DUTY, RECRUITING, AND ESTABLISHMENT OF THE RESERVE}

"I should not deem a man-of-war complete without a body of Marines . . imbued with that esprit that has so long characterized the 'old Corps'. ${ }^{27}$

Commodore Joshua R. Sands, USN:

Letter to Brigadier General Archibald Henderson, USMC, 1852

"The Marines . . will never disappoint the most sanguine expectations of their country - never! I have never known one who would not readily advance in battle. ${ }^{28}$

Captain C. W. Morgan, USN:

Letter to Brigadier General Archibald Henderson, USMC, 1852

"A ship without Marines is like a garment without buttons. ${ }^{129}$

Admiral David D. Porter, USN:

Letter to Colonel John Harris,

USMC, 1863

${ }^{27}$ Heinl, Robert, Debs, Jr., Dictionary of Military and Naval Quotations, (Annapolis, Maryland, 1966), p. 183.

${ }^{28}$ Ibid., p. 183.

${ }^{29}$ Ibid., p. 183. 
American westward settlement continued as word spread that there was plenty of bountiful land in the Pacific Northwest. Official reports and maps from explorations such as the Wilkes Expedition only served to fuel this migration

Joint occupation treaties between Great Britain and the United States were established in 1818 and 1827. An estimated 800 American pioneers crossed the Oregon Trail in 1843 , to settle in Oregon. ${ }^{30}$ This number greatly increased later as an indirect result of the California Gold Rush in 1849.

These American settlers were a vigorous, productive, and conservative group who built upon the traditions of their past and that of the national heritage. The powerful American ideology known as Manifest Destiny held that God, Nature, and Fate combined to bring into focus the right of the United States to expand westward to the Pacific. This was based upon the natural superiority of American democracy, religious freedom, economic opportunity, and social mobility.

By far the most numerous and politically influential group of these American settlers to Oregon were the farmers and businessmen. The region was the closest source of lumber, grain, and meat for the support of events in California. Borrowing from the American political tradition which had arisen from the Mayflower Compact of 1620 , these Oregon settlers created their own local government. This assured the protection

${ }^{30}$ Dodds, Gordon. B., The American Northwest, (Arlington Heights, Illinois, 1986), p. 62. 
of life, property, and law and order in areas where there was either no government, or no effective government. This resulted in the creation of the successful Oregon Provisional Government.

Despite occasional tensions with the British Hudson's Bay Company, and more serious confrontations regarding Indian relations, this provisional government kept the peace until the organization of Oregon Territory in August 1848. This traditional structure of government successfully led to Oregon being admitted to the Union as the thirty-third state on 14 February 1859.

Meanwhile, the United States Marine Corps continued its service principally by providing detachments aboard US Navy warships. This type of service undoubtedly resulted in many routine ship visits by Marines to Oregon. Marine Corps strength in 1847 stood at 71 officers and 2,319 enlisted Marines.

The first key event in United States Marine Corps history during these times was the Mexican War of 1846-48, when as a result of their valor in leading the American assault into Mexico City, Marines acquired the first line of their hymn: "From the Halls of Montezuma." It was here at the National Palace that Marine 2nd Lieutenant A. S. Nicholson, cut down the Mexican colors and hoisted up the Stars and Stripes ${ }^{31}$ Back in Oregon Territory, a little known event involving Marine First Lieutenant Archibald H. Gillespie took place deep in Indian country at Klamath Lake, on 9 May 1846. Gillespie was serving as a diplomatic agent for President James K. Polk. Originally an enlisted

${ }^{31}$ Heinl, Soldiers of the Sea, p. 52. 
Marine, the redheaded Gillespie was described as "an elegant, precise man with a stiff pointed beard, and a temper of the same description. ${ }^{32}$ Late in 1845 , Gillespie received secret memorized orders concerning the possible outbreak of war from the President. He was instructed to make his way overland from Washington through Mexico, to Commodore John D. Sloat, commanding the United States Navy Pacific Squadron. Gillespie then proceeded to deliver related instructions to two of the President's trusted agents in the west: Consul Thomas Larkin in Monterey, and Captain John C. Fremont, US Army, who was heading a "scientific expedition" then exploring and mapping northern California and Oregon. Both of these regions were at the same time, also coveted by Britain. Gillespie successfully completed his unusual mission at Klamath Lake, Oregon (which would by strange coincidence become the site of a World War II Marine Barracks exactly one hundred years later)

Aside from the occasional ship visits to Oregon by United States Navy and Marine personnel, the first American military forces to be stationed in Oregon Territory were assigned in 1849 . These army units consisted of two companies of the 1st U.S. Artillery. On 13 May 1849, they arrived by sea at the mouth of the Columbia River, from New York. While one company was soon located north to the Puget Sound area, the other was based at Fort Vancouver, just across the Columbia River from Portland. These army units, and the majority of those which later followed, were based in Oregon territory for the primary purpose of supervising and enforcing the peace between

$$
{ }^{32} \text { Ibid., p. } 45 .
$$


American settlers arriving from the east, and the original native American Indians who inhabited the region. Later, Army units would also be assigned to Oregon from the Civil War period through World War II for the coastal defense mission. There is no record of Marine units being employed in Oregon territory for either Indian pacification or coastal defense purposes.

By 31 December 1860, there were 26 regular U.S. Army infantry and field artillery units stationed at nine forts and two camps in Oregon and Washington territory. This deployment changed dramatically within the next year because of the demand for Union troops in the eastern United States at the outbreak of the Civil War. United States naval ship activity in the area did see an increase due to the effectiveness of Confederate raiders on the high seas. Led by such well-known Confederate cruisers as the Alabama. Florida, and Shenandoah, over 200 United States vessels valued at approximately $\$ 25,000,000$ were destroyed by the end of the war. The CSS Shenandoah brought the Civil War directly to the Pacific Northwest when she captured 24 United States vessels on 16 June 1865, in the Bering Sea off Alaska. The Confederate raider burned 20 of these, which belonged to the New England whaling fleet. ${ }^{33}$ This raider threat was the prime motivation for the federal government authorizing construction of Fort Stevens at the mouth of the Columbia River in $1862 .{ }^{34}$

${ }^{33}$ Silverstone, Paul H., Warships of the Civil War Navies, (Annapolis, Maryland, 1989), p. 214.

${ }^{34} \mathrm{Hanft}$, Marshall, Fort Stevens, Oregon's Defender at the River of the West, (Hammond \& Portland, Oregon, 1980), p. 9. 
Marine Corps strength was increased by executive order in 1861 from a total of 1,892 to 4,167 officers and Marines. With the increase of United States warship escort and patrol visitation to Astoria and Portland during the Civil War, it is known that many United States Marines from these ships' detachments also visited Oregon. Aside from an occasional mention of such an Oregon port visit in a local paper, the specific history of these Marines has been lost. It can only be assumed that their routine was much like that of other Marine detachments: long hours of routine shipboard duty, maintenance on ship's guns, personal weapons and equipment, drill, classes, landing party duty, color guards, security duty, and a much appreciated port call with its liberty period. No record was found of Marines committing any serious infractions while enjoying liberty in Astoria or Portland.

Portland had rapidly surpassed Astoria as the main commercial center in Oregon. It had been determined by the majority of merchant ship captains to be the easternmost reliable head of navigation on the Columbia and Willamette Rivers. Almost all produce from the fertile Willamette Valley wound its way northward to Portland. The city had also built a wagon road over its western hills to open up the wheat trade in the Tualatin Valley. By 1851, San Francisco became the first reliable export market for several sailing and steamship lines in Portland. By the 1860 's, the foundation of regional industry in Oregon had been created by other mining operations in southern and eastern Oregon, eastern Washington, Idaho, and Montana. As always, the primary benefactors on the 

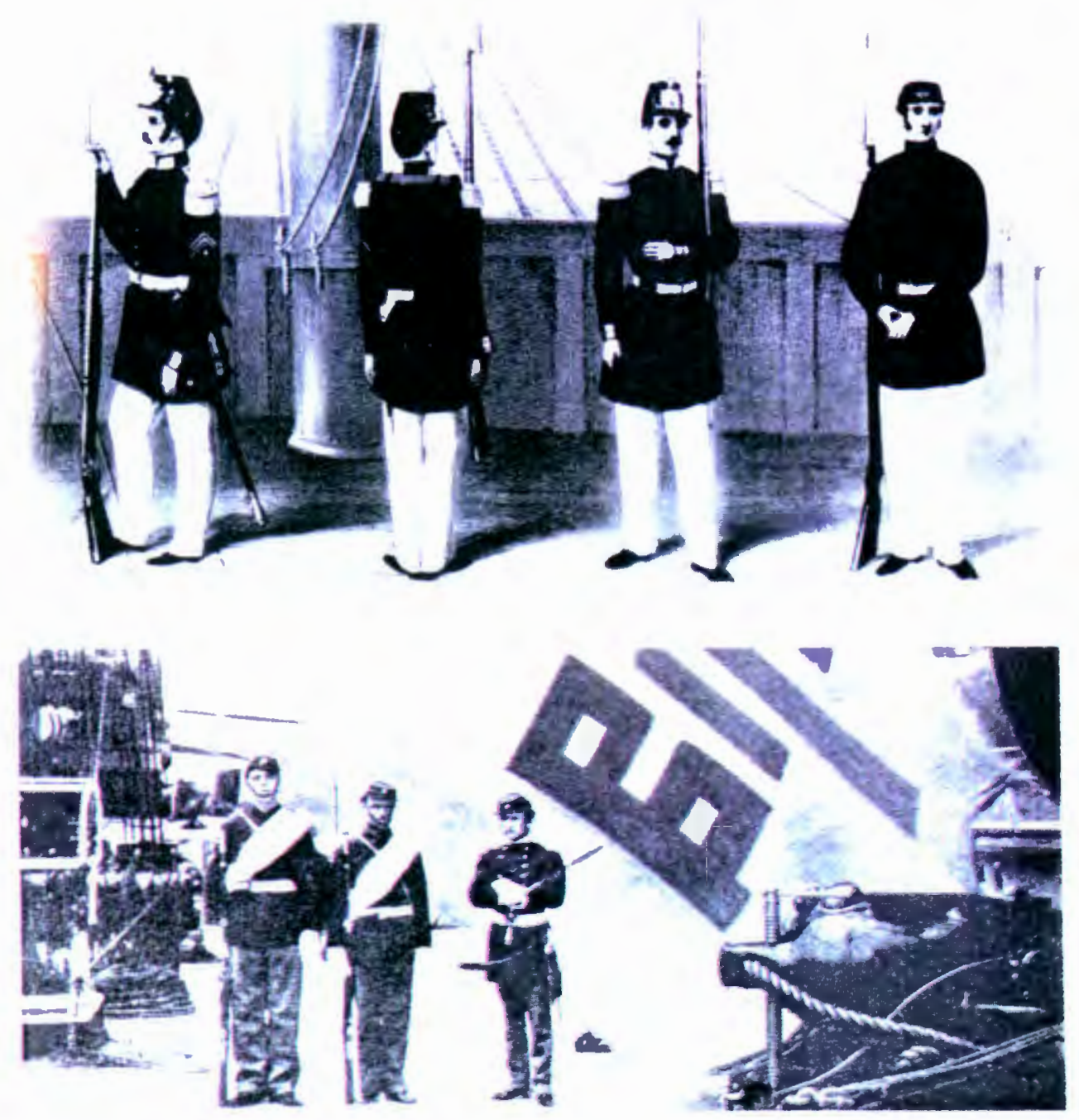

Figure 4 (Top): Shipboard Marines in 1859, immediately prior to the Civil War. Left to right: first sergeant, corporal and private (full dress), and a private (undress). All wear white summer trousers and light infantry hunting-horn cap device.

Figure 5 (Bottom): Shipboard Marines in 1871, aboard the USS Colorado following landings on Kangwha-Do, Korea. Here, Corporal Brown and Private Purvis both won Medals of Honor. They pose with their Commanding Officer, Captain Tilton USMC, before captured flag.

Soldiers of the Sea by Heinl, p. $62 \& 78$. 
mining frontier were the farmers, merchants, and transport men.

By the 1880 's, Oregon was awaiting the transcontinental railroad. This represented significant progress and wealth, for it ushered in considerable economic growth and cultural change through World War I well into the 1920's.

Marine Corps strength in 1876 was 75 officers and 2,074 enlisted Marines. Though some have described the latter half of the 19th century as a transition period in which the United States Marine Corps was simply "marking time" this is far from the actual case. Aside from the endless routine of shipboard life, dozens of examples exist of combat ready Marines from one ship's detachment after another making landings to protect and enforce American interests ashore. In the fine tradition of Sergeant Stearns and the Marines of the 1838-1842 Wilkes Expedition, landings were conducted in: Formosa (1867), Japan (1867 and 1868), Uruguay (1868), the west coast of Mexico (1870), Colombia (1873), the Hawaiian Islands (1874 and 1889), Egypt (1882), Korea (1888 and 1894), Haiti (1888), Samoa (1888), Argentina (1890), Chile (1891), Navassa Island (1891), Nicaragua (1894 and 1896), North China (1894-95), and Panama $(1895) .{ }^{35}$ Some of these landings, particularly Korea and Panama, were significantly large by the standards of the day. The 12 April 1885 landing in Panama saw the employment of the first United States Marine brigade (comprised of three battalions) ever organized. It is of further interest to note that at the height of excitement during this peacekeeping mission, when informed that a brigade of United States Marines was

${ }^{35}$ Heinl, Soldiers of the Sea, p. 88. 
ashore, the captain of a neighboring British warship exclaimed: "Tranquility is then assured. ${ }^{136}$ American correspondent Richard Harding Davis coined a more well-known phrase when he reported simply: "The Marines have landed and have the situation well in hand." ${ }^{37}$

In 1898, on the eve of the Spanish-American War, Marine Corps strength had grown to 119 officers and 4,713 enlisted Marines. Within a year, this had further increased to 201 officers and 6,062 enlisted Marines.

Up to this point in Oregon history, United States Marines had visited the Pacific Northwest only aboard United States Navy warships. This was soon to change. With America's full rise to power toward the turn of the century, the increasing responsibility of being a growing maritime power took on a much more significant meaning. The conquest of former Spanish territories in the Philippines and Guam meant the expanded need for naval assets in the western Pacific. American naval expansion resulted in the growth of the United States Marine Corps. At the same time, growing tensions in Europe and the corresponding military buildup made Americans aware of the need for a strong military. The global reality and need to maintain a balance of power made America much more aware of the need for readiness, especially when the war in Europe broke out in 1914 and soon progressed into a global war.

${ }^{36}$ Ibid., p. 94.
${ }^{37}$ Ibid., p. 94. 
World War I had a significant impact upon both the United States and the Marine Corps. The nation had finally learned the significance of the advice rendered by its first president, for as George Washington had once said: "To be prepared for war is one of the most effectual means of preserving peace." In 1916, the United States Congress first authorized a Marine Corps Reserve ${ }^{38}$ The inception of this was greatly assisted by a long struggle and sequence of events that had transpired within the United States Navy over several decades. This act would lead directly to the establishment of a Marine Corps Reserve organization in Oregon.

As early as the Civil War period, both Congressional and Naval leaders had recognized the need for a Naval Reserve. One of these men was Admiral J. G. Walker, Chief of the Bureau of Navigation of the Navy Department. He wrote to the Secretary of the Navy on 15 October 1889 :

" . . the subject of speedily establishing a system of naval reserves, to meet the demands of the country, for rapidly manning and increasing its fleet upon the outbreak of war, is vitally important. ${ }^{139}$

In a comprehensive report, Admiral Walker shared insights which were later incorporated into a Congressional bill by Senator Whitthorne of Tennessee. These ideas

\footnotetext{
${ }^{38}$ Public Affairs Unit 4-1, The Marine Corps Reserve, A History, (Washington, D.C., 1966), p. V.

${ }^{39}$ Ibid., p. 1.
} 
became nationally known as the "Whitthorne Bill," and in it, Walker directly addressed his main concern:

"At present, no means exist for providing the fleet with a single trained man, beyond the number prescribed by law for the peace establishment, and it would seem that no argument should be necessary to secure the required legislative authority.

The study and energy of maritime nations is being devoted to placing the reserves of men, as well as materials, in such a state of training readiness as to make them available for effective service on 24-hour notice.

Rapid mobilization may be said to be the leading naval question of the day, and the recent naval maneuvers aboard have given occasion for the frequent statement of the opinion that to readiness of ships and guns must be joined an equal readiness of men, to make any system of mobilization complete and effective." 40

Unfortunately, the politics and economics of the next thirty years dictated that a reserve under the operational control of the Navy was not yet to be. Instead, emphasis was placed on State-controlled naval militia organizations, which were supplied and assisted by the Navy Department. Accordingly, on 23 August 1892, Secretary of the Navy B. F. Tracy reported that the naval Appropriation act of 19 July 1892, had the following provision:

"For arms and equipment connected therewith for naval militia of various States, under such regulations as the Secretary of the Navy may prescribe, $\$ 25,000.00 \ldots$. ."41 Following passage of this act, seven states were able to muster into their Naval Militias a total of only 1,794 officers and men. As evidenced by this low number, the

${ }^{40}$ Ibid., p. 1.

${ }^{41}$ Ibid., p. 2. 
state Naval Militias clearly could not fill the need for a second line of defense. It should be noted, however, that Marines did participate within the Naval Militia of some individual states. Of specific interest, dating almost from the inception of the Naval Militia program of 1892, was the spirited 1st Marine Corps Reserve Company of the New York State Naval Militia. Established in 1893, many members of this unit would later distinguish themselves in World War I. The early state Naval Militias of Massachusetts and Louisiana also had active Marine branches. ${ }^{42}$

Though it did not have a Marine unit, Oregon did in 1898, upon the outbreak of war with Spain, form its own "Naval Militia" as part of the Oregon National Guard. ${ }^{43}$ The governor was petitioned to form a naval battalion by a number of prominent Portland citizens in April 1898, with the result that two companies were formed in Portland and one in Astoria. Each unit consisted of approximately four officers and 39 enlisted men, with state funds being allocated to purchase uniforms, equipment, and weapons. Four boats. were loaned to the battalion by the Navy and annual training cruises aboard warships were established.

The Oregon Naval Militia was not activated into federal service during the brief Spanish-American War. This had a negative impact on morale, and when the battalion was reorganized into three divisions in May 1899, unit strength dropped to 69 men.

${ }^{42} \underline{\text { Ibid., p. } 3-4 .}$

${ }^{43}$ Mewha, John, "The Oregon Guard's 'Navy'" and Columbia River Maritime Museum, Quarterdeck Review, Vol. 12, No. 4, (Astoria, Oregon, Fall 1985), p. 2-4. 


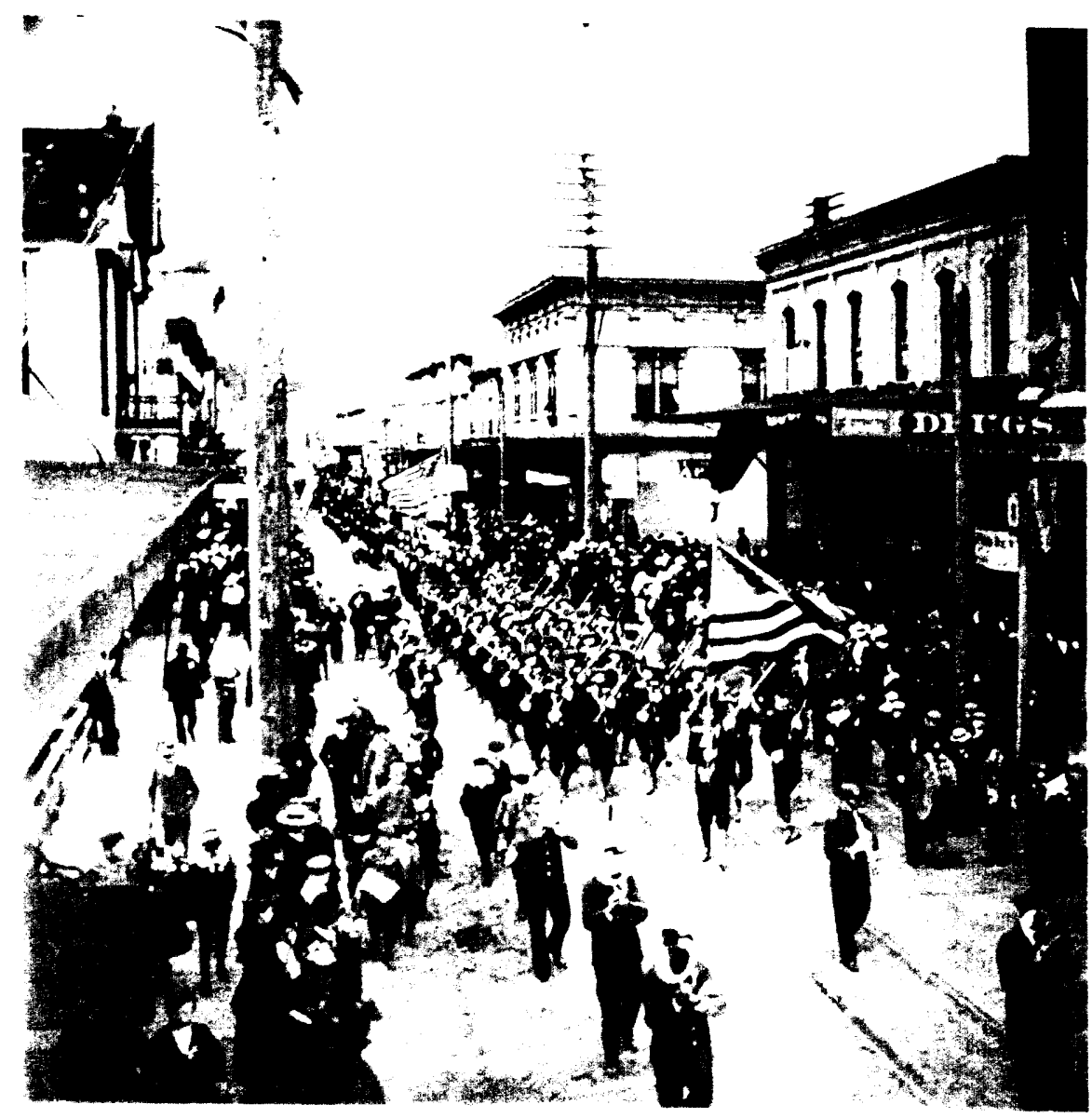

Figure 6: Units of the Oregon Naval Militia, which was formed in 1898, marching in Astoria. Two companies were in Portland and one was in Astoria. Each unit consisted of approximately 4 officers and 39 enlisted men. These units were disbanded in 1902 , and the personnel transferred into the Oregon National Guard. This was the first reserve "Naval Militia" in Oregon. The United States Marine Corps Reserve was formed in 1916 and came to Oregon in 1930.

Photo courtesy of Clatsop County Historical Society 
Inspections also revealed that weapons were not being properly maintained. Based upon these negative factors, in 1902, the officers were discharged and the enlisted men were transferred over to the Oregon National Guard. ${ }^{44}$

While the Department of the Navy and Congress struggled to transition from state Naval Militias to a national naval reserve, another story was unfolding on the West Coast and in Oregon. This involved the legend passed down at the headquarters of what is today the 12th Marine Corps District, San Diego, California. This unit is now, geographically, the largest of the Marine Corps recruiting districts, encompassing Oregon, five other continental states, Alaska, Hawaii, and Micronesia.

The actual legend is that of the first Marine recruiter sent into the vast area beyond the Rocky Mountains in the late 1800's. His mission was to comb this area for the raw human material from which Marines are made: strong, lean, honorable men with physical courage and moral commitment. This was the kind of man that America's expanding world interests needed in her Marines. As the legend has it, an old Marine gunnery sergeant was given a horse and enough spending money to last a month, and he was told to send such suitable young men to San Diego, California, where the Marine Corps had just established a recruit training depot. The "gunny" was never heard from again, but a steady stream of select young men from the mountains, valleys, and coastal areas of the West continued to show up in San Diego. Obviously, some of these stout physical specimens came from the logging camps, farms, canneries, and towns of

\footnotetext{
${ }^{44}$ Ibid., p. 3
} 
Oregon. The actual name of the first native born Marine from Oregon has been lost. We can only speculate whether a native son or resident of Oregon ever served the Marine Corps in the Civil War, or in the few decades that followed.

It is known that on 1 May 1898 , at the Battle of Manila Bay, in the SpanishAmerican War, Marine Private Charles C. Schroeder, was serving a five-year enlistment aboard Admiral George Dewey's flagship, the protected cruiser USS Olympia. Born in Chicago in 1877 , Schroeder had migrated as a youth west with his German immigrant parents to make a home in Oak Grove, Oregon. Schroeder would one day, in 1950, track on a map in his parlor the Korean War combat trail of his Marine grandson, Private First Class Clyde T. Henderson, of Portland, serving with Weapons Company, 2nd Battalion, 1st Marine Regiment, 1st Marine Division, from the Inchon Landing to the Battle of the Chosin Reservoir. ${ }^{45}$

On 6 September 1899, Captain Albert S. McLemore, United States Marine Corps, arrived in San Francisco to head the West Coast recruiting effort. Though he was not the first Marine to recruit on the West Coast, his appearance signified the establishment of a separate recruiting office. Prior to this, all enlistments had been processed by personnel from the Marine Barracks, Mare Island, California. Previous recruiting efforts had changed little from those used since the Revolutionary War, and

\footnotetext{
${ }^{45}$ Personal Interview between Clyde T. Henderson and author, Portland, Oregon, 7 March 1994.
} 


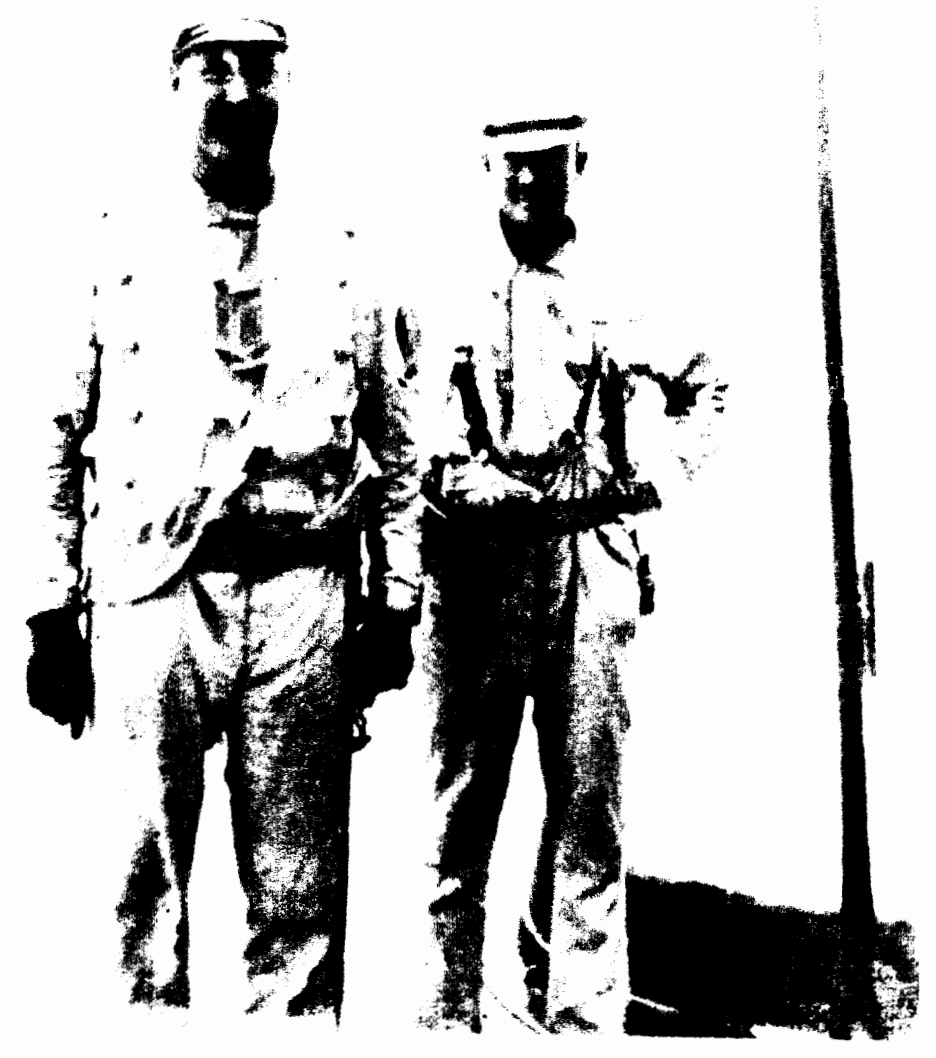

Figure 7: Marines of the battleship USS Oregen detachment immediately following the 3 July 1898 Battle of Santiago Bay, Cuba. Captain Randolph Dickins is on the left, 2nd Lieutenant Austin R. Davis is on the right.

Photo courtesy of Oregon Historical Society 
most often consisted of a sergeant, one or more corporals, and a bugler conducting a mobile series of what was known as a "recruiting rendezvous" within areas where prospective recruits might be found. Captain McLemore's 1899 San Francisco office marked the first attempt at systematic Marine Corps recruiting on the West Coast. ${ }^{46}$

Unfortunately, due to a scarcity of qualified applicants from the region, this West Coast office was temporarily halted on 31 December 1903 . The main drawing area for Marine recruits continued to be in the larger cities east of the Mississippi River.

On 15 March 1905, the Marine Corps reopened recruiting activities on the West Coast when Captain Leaf M. Harding began operations again in San Francisco. This second effort was in operation for a mere fourteen months when disaster struck in the form of the famous San Francisco earthquake of 18 April 1906. The recruiting station building was leveled and activities were resumed from Oakland on 16 May 1906. During this period, Marines from the recruiting station were commended by the officials and citizens of San Francisco for their "valuable assistance" during the earthquake and subsequent fire.

On 30 September 1906, West Coast recruiting efforts were again suspended. This time, the failure to procure qualified recruits was due primarily to the wave of economic prosperity which had come to America. Few men were attracted by a private's monthly pay of $\$ 13.00$, which even the Commandant of the Marine Corps characterized 1957, p. 1.

${ }^{46}$ History of the 12th Marine Corps District, San Francisco, California, 19 April 
as a sum: "so small in comparison with the wages easily obtained in civil life, that enlistments may be said to be in spite of the pay rather than for it. ${ }^{47}$

On 9 April 1909, a third attempt to recruit Marines on the West Coast was undertaken by First Lieutenant Harold Calvocoresses. Again, this effort was focused on the main population center of San Francisco. With the number of recruits rising in May 1909 , to nineteen, it was now clear that the Marine Corps had a sound base upon which to commence a West Coast recruiting effort. Further evidence of this success was in March 1910, when the official title of the Recruiting District of California was changed to the Pacific Coast Recruiting District. This was reflected by the growing chain of substations which began to branch out from San Francisco.

On 1 March 1910, the United States Marine Corps established a permanent presence in Oregon when it opened twin recruiting substations in Portland and Eugene. ${ }^{48}$ The United States Marine Corps Recruiting Office was first listed in the 1911 Portland City Directory as being at $2531 / 2$ Washington Street. The first Portland Marine Recruiter was listed in 1912 as being Sergeant Thomas W. Dench, with the first Marine officer, Captain H. H. Minard, being assigned to Portland in 1914, when the Marine Recruiting Office moved to 21-2nd North, in Portland.

${ }^{47}$ Ibid., p. 1

${ }^{48}$ Ibid., p. 2. 


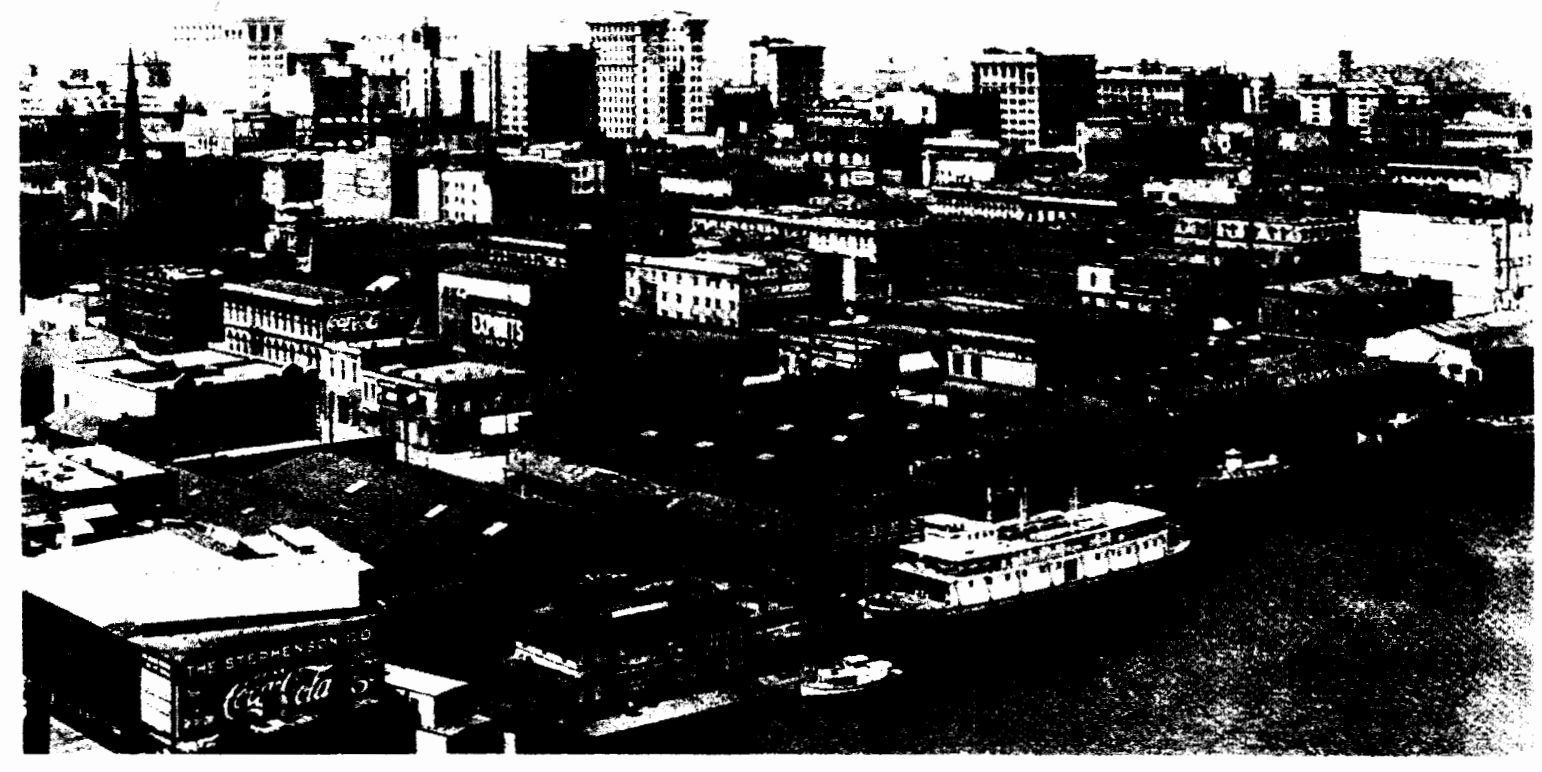

Figure 8: The United States Marine Corps made its permanent presence in Portland known when it opened a recruiting office at 253 1/2 Washington Street. The first recruiter was listed in the 1912 city directory as Sergeant Thomas W. Dench, while the first officer, Captain H.H. Minard, arrived in 1914. This is what the waterfront looked like that year. World War I was on the horizon.

Photo courtesy of Oregon Historical Society ( \#12732) 
Later, to assist in the 1917 World War I and 1941 World War II recruiting efforts, Women Marines were assigned to the Recruiting Station in Portland. The first was Elizabeth "Bessie" Welke in 1917, while the first assigned to Portland in WWII was Staff Sergeant Catherine "Kay" Wilson Haedinger in 1943.

There would be many innovative triumphs exemplified by the Marine Corps recruiting effort in Oregon, ranging from physical acts of prowess such as the annual Mt. Hood to Coast Run participation, to the area of grace and beauty, such as the 1953 "drafting" of Dorothy Johnson, a future "Miss Oregon" as "Miss Marine Corps Reserve." ${ }^{49}$ But undoubtedly the most interesting was at Portland's Civic Stadium, when on 16 June 1964, between games of a Portland Beaver baseball game double header, 56 Oregonians took the oath to become Marines and reported to bootcamp, in San Diego, as "the Beaver Platoon."

The Portland Marine Corps Recruiting Office would continue to grow until Portland's location became by April 1986, one of the seven main Recruiting Stations serving as a prime nerve center for over one hundred 12th Marine Corps District recruiting substations. In Oregon alone, these substations were represented by Eugene, Salem, Beaverton, Gresham, Albany, East Portland, The Dalles, Medford, Pendleton, and the Officer Selection Office at Oregon State University in Corvallis.

Meanwhile, back in Washington D.C., the turn of the century debate and struggle continued to transform the state Naval Militias into a full fledged United States Navy

${ }^{49}$ Leatherneck, Magazine of the Marines, October 1955, p. 48-49. 
Reserve and United States Marine Corps Reserve. This process would eventually have considerable impact on events in Oregon.

By 1 November 1900, in light of mobilization lessons learned during the SpanishAmerican War, the continued weakness of the state Naval Militia was thoroughly examined and reported upon by Lieutenant Commander William H. Southerland. As Officer in Charge of the Naval Militia Office, he reported:

"I call your attention to these facts to show the absolute necessity for the creation, in addition to the naval militia organizations, of a government or national reserve force, which should be organized entirely under the control of the Navy Department." 50

Within six years, the Secretary of the Navy, George V. L. Meyer would heartily concur and further press this same issue by stating:

"In every foreign country possessing a first-class navy, provision is made for a large reserve of trained men, to be added to the enlisted personnel of the navy at the outbreak of war. Our provision for this contingency is inadequate." 51

Meanwhile, California and Washington state had both continued Naval Militia programs, and the Navy hoped to encourage a renewed effort in Oregon. The offer of the loan by the Navy of a fully equipped warship for training purposes was made to the state. In 1910, Acting Governor Bowerman created the Oregon Naval Reserve as an

\footnotetext{
${ }^{50}$ Public Affairs Unit 4-1, The Marine Corps Reserve, A History, p. 2.

${ }^{51}$ Ibid., p. 2.
} 
adjunct of the state National Guard. ${ }^{52}$ True to its word, the Navy assigned the oldprotected cruiser USS Boston as a training ship to the Oregon Naval Reserve in June of 1911.

On 1 December 1911, fully one year and nine months after the first regular Marine Corps presence had been established in Oregon by recruiters, Secretary of the Navy Meyer reported:

"The department submitted to the 61 st Congress a draft of a bill embodying its ideas for the legal establishment of a national reserve of officers and men (introduced as Senate 7644 and House of Representatives 24942) entitled: A bill to provide for a reserve of personnel for the U.S. Navy and Marine Corps and for its enrollment. 1153

This was passed, and within 1912, an Office of Naval Reserve was established under the Bureau of Navigation. However, on 4 October 1913, the Chief of the Bureau of Navigation, Admiral Victor Blue, reported to the Secretary of the Navy concerning problems in increasing reserve manpower levels, which were a mere 2,600 volunteer officers and men. Admiral Blue stated:

"The importance of having a regularly enrolled and organized Naval Reserve for service in time of war cannot be too forcibly impressed upon the country. ... No doubt if Congress should authorize the formation of a national reserve in a manner that would make the proposition attractive, there would be no difficulty in recruiting the full quota in a very short time. ${ }^{154}$

${ }^{52}$ Mewha, The Oregon Guard's Navy, p. 3.

${ }^{53}$ Ibid., p. 4.

${ }^{54}$ Ibid., p. 2. 
As a result of this need to improve both the organization and the manpower level within the Naval Militia, on 12 April 1914, the Navy Department published General Order Number 93. This firmly established a Division of Naval Militia Affairs within the Navy Department.

Though several Marine detachments had been organized within a number of the state Naval Militias dating back as far as 19 July 1892 , their actual status as official United States Marine Corps units was obscure. Following almost twenty-three years of such ambiguity, events now transpired which clearly defined the role of Marines within the new federal Naval Militia.

On 16 February 1914, as Europe teetered on the edge of world war, passage of the Naval Militia Act finally gave the Navy Department virtual control of the Naval Militia. ${ }^{5 s}$ Commencing with this date, the colorful Secretary of the Navy, Josephus Daniels, centered his efforts on expanding the Navy and creating a credible Naval Reserve. Working on a similar goal at the same time, the Commandant of the Marine Corps, Major General George Barnett, focused on strengthening the Marine Corps and forming a capable Marine Corps Reserve.

Following a series of conferences between Secretary of the Navy Daniels and Commandant Barnett, a coordinated plan was agreed upon: the Navy would request a Reserve in 1914, to be formally brought into law in 1915, while the Marine Corps would seek a Reserve in 1915, to be actually authorized in 1916. Given the ominous string of

\footnotetext{
${ }^{55}$ Ibid., p. 4.
} 
events which were transpiring in Europe and throughout the world, this joint NavyMarine Corps strategy was given considerable impetus. It's success was indicated on 3 March 1915, when the 63rd Congress passed an act providing for a larger Navy and creating a Naval Reserve. ${ }^{56}$ Within seven months, in his Annual Report for Fiscal Year 1915, the Commandant of the Marine Corps made the following statement:

"The Marine Corps has no reserves. During the last session of Congress, a Naval Reserve, consisting of men who have seen service in the Navy, was created. The adoption of a similar proviso for the Marine Corps is recommended." 57

While Congress addressed the Commandant's recommendation, on 10 July 1915, Navy Department General Order Number 153 made some significant provisions and assumptions, stating that members of the Marine Corps Branch, Naval Militia, would be organized as follows:

"Officers - Marine Companies,

For each Marine company of 60 or less enlisted men, there will be allowed the following officers:

1 Captain.

1 First Lieutenant.

1 Second Lieutenant.

For a Marine company of more than 60 enlisted men, there will be allowed an additional second lieutenant.

Noncommissioned Officers and other Enlisted Men.

For each Marine company of 48 enlisted men, there will be allowed noncommissioned officers and other enlisted men as follows:

(a) 1 First Sergeant, 1 Gunnery Sergeant, 4 Sergeants, 5 Corporals, 1 Drummer, 1 Trumpeter.

(b) 35 Privates.

${ }^{56}$ Ibid., p. 4.

${ }^{57}$ Ibid., p. 4. 
For each additional 8 privates over 35 , an additional corporal may be appointed; and for each additional 16 privates over 35, an additional sergeant may be appointed.

In Marine sections, the following officers will be allowed:

1 First Lieutenant, and the following officers and other enlisted men:

1 First Sergeant.

2 Sergeants.

1 Trumpeter

17 Privates.

Whenever a Marine company increases in size to 12 squads, it will be divided into 2 companies. ${ }^{158}$

In an additional effort to acquire sound experience, and men of proven character, former enlisted men of both the regular Navy and Marine Corps were encouraged to enter the Naval Militia. General Order Number 153 thus provided that:

"Any former enlisted man of the U.S. Navy or Marine Corps who is in good standing in the community and who was honorably discharged will be allowed to enter the Naval Militia without professional examination in any unit of organization or headquarters of a brigade or of a battalion, with such rate or rank as he last held in the U.S. Navy or Marine Corps. . . ."59

Thus was addressed within the Navy Department, the planned formation of Marine Corps units up to and including both the battalion and brigade level. This was of course governed by both the availability of Marines and the necessary funding to support them.

Everything was now in place, awaiting only the proper timing and official authorization of Congress.

${ }^{58}$ Ibid., p. 3.

${ }^{59}$ Ibid., p. 3. 


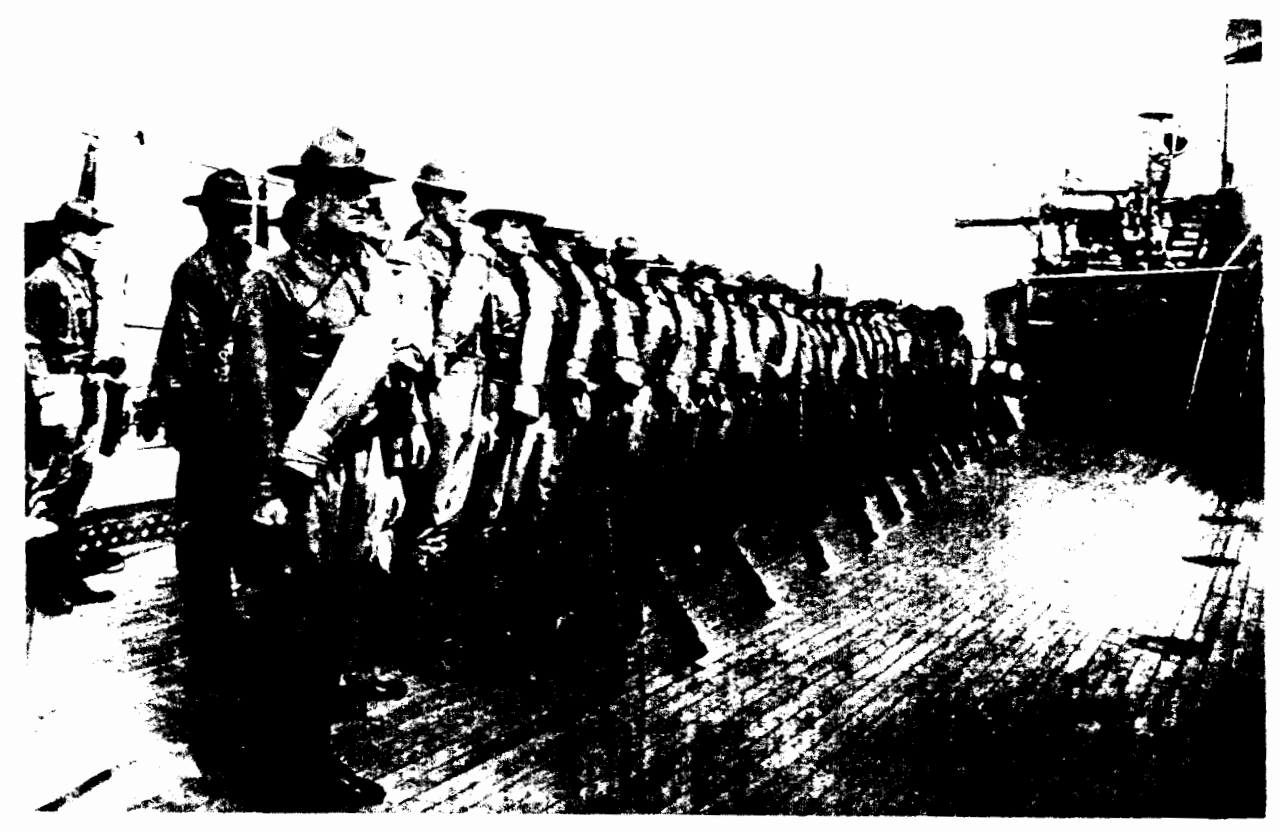

Figure 9: Marine battleship detachment in 1915, fully prepared to make a landing. These experienced regulars typified the expeditionary years leading up to World War I, and they provided the backbone for the Marine regiments which fought in France.

Photo courtesy of United States Naval Institute 
The actual birth of the United States Marine Corps Reserve took place on 29 August 1916. On this date, Congress passed the naval appropriations act for the first half of fiscal year 1917, which included the establishment of the Marine Corps Reserve. Two days later, under this statutory authority, the Navy Department issued General Order Number 231, which stated:

"A U.S. Marine Corps Reserve, to be a constituent part of the Marine Corps and in addition to the authorized strength thereof, is hereby established. 1160

It was now only a matter of time until Oregon had its own Marine Corps Reserve organization.

${ }^{60}$ Ibid., p. 4 


\section{CHAPTER IV}

\section{WORLD WAR I AND THE OREGON RESERVE}

"When war was declared, I tendered, ready and equipped, two regiments of Marines to be incorporated in the Army.

Some Army officers were not keen to accept them. ${ }^{161}$

Josephus Daniel, Secretary of the Navy April 1917

"Retreat, hell!' We just got here!'62

Captain Lloyd Williams USMC, 5th Marine Regiment, Battle of Belleau Wood, 5 June 1918

"They never failed me. I look back on my service with the Marine Brigade with more pride and satisfaction than on any other equal period in my long Army career. ${ }^{163}$

Major General James G. Harbord, United States Army, General Pershing's Chief of Staff \& Commander, 4th Marine Brigade

${ }^{61}$ Heinl, Soldiers of the Sea, p. 194.

${ }^{62}$ Murray, Regina Waldron, "Retreat, Hell . . " Proceedings, (Annapolis, Maryland, January 1985), p. 48.

${ }^{63}$ Heinl, Soldiers of the Sea, p. 191. 
The August 1914 outbreak of World War I threatened the possibility of American involvement. In Oregon, the training of the 200 man Naval Militia intensified. After first having assigned the protected cruiser USS Boston to the Oregon Naval Reserve in June of 1911, the Navy then added the torpedo boat USS Goldsborough, which had been built and launched in Portland by Wolff and Zwicker in $1899 .^{64}$

In 1915, the Oregon Naval Reserve deployed for a gunnery training cruise aboard the USS Albany and in 1916, the aging USS Boston was replaced by the cruiser USS Marblehead, which included in its crew a detachment of 25 "marines" assigned from the National Guard. With the American declaration of war against Germany on 6 April 1917, all Navy warships were recalled from the Oregon Naval Reserve, and all personnel were directed to report to the Puget Sound Navy Yard for active duty. Later, a second Oregon naval battalion was raised and sent north to Washington.

American entry into World War I eventually meant the end of the Oregon Naval Reserve. Following the war, after having trained 750 of the 3,000 Oregonians who served in the Navy during the war, it was officially disbanded on 8 December $1921 .^{65}$

For the United States Marine Corps and the new Marine Corps Reserve, a different story awaited. Though the Reserve had been established in 1916, the population base in Oregon did not yet justify the founding of an actual reserve unit in

${ }^{64}$ Quarterdeck Review, Vol. 12, No. 4, Columbia Maritime Museum, Fall 1985, p. 3.

${ }^{65}$ Quarterdeck Review, Columbia Maritime Museum, p. 4. 
Portland. The Portland Recruiting Station had been from 1 March 1910, the heart of Marine Corps activities in Oregon, and it would continue to be so until the founding of the first Oregon Marine Reserve unit in Portland, in 1930

By April 1917, Major Albert S. McLemore, who had originally opened up the first West Coast recruiting office in San Francisco on 6 September 1899, and was now in charge of all Marine Corps recruiting, selected the motto: "First to Fight." McLemore was soon almost overwhelmed by his own success. Active duty recruiting had moved into such high gear that additional administrative personnel were needed. This need was aided by the formation at Marine Corps headquarters, in Washington, D.C. of the Women Marine Reserves. Of the 305 Women Marines (or "Marinettes" as they were then known) who served during World War I, it is known that several served in Portland, Oregon, assisting the recruiting effort. ${ }^{66}$ One of these was Private First Class Elizabeth "Bessie" Welke, an administrative clerk who later married a male Marine from the Portland recruiting staff. To her goes the distinction of being Oregon's first Women Marine. ${ }^{67}$ Age limit for the women Reserves was stated as being between 18 and 40, with all women being advised that they were subject to the same rules and regulations, and received the same pay and allowances as their enlisted male counterparts. Their

${ }^{66}$ Public Affairs Unit 4-1, The Marine Corps Reserve Story, p. 19.

${ }^{67}$ Personal Interview between Ms. Irma Price and author, Portland, Oregon, 15 March 1994. 
service during World War I was characterized as "capable and industrious. ${ }^{168}$ Following the end of World War I, on 30 July 1919, Major General Commandant George Barnett would call for the discharge of all "female reservists," stating:

"It is a pleasure, but not by any means an unexpected one, to be able to state that the service rendered by the reservists (female) has been uniformly excellent. It has, in fact, been exactly what the intelligence and goodness of our countrywomen would lead one to expect."

Women Marines would again return to service in World War II, and continue to serve as a permanent part of the Marine Corps through the 1991 Gulf War, to the present.

Meanwhile, back in 1916, the Naval Personnel Bill had enlarged the Marine Corps by almost 50\%. The Recruit Depots at Parris Island, South Carolina, and Mare Island, California, were functioning well with regard to the increased inflow from the aggressive Marine recruiting campaigns. A new base at San Diego had also been established. By initiative, organization, thrift and wise management, the Marine Corps in early 1917 found itself better led, larger, more trained and combat ready than at any time in its prior history. The real benefits of the years from 1898 to 1917 were the combat leadership experience gained in the series of global, fighting expeditions in which Marines of all ranks had become tough, proficient, and adaptable. Nowhere was this better represented than in the capable leadership of men such as George Barnett, John Archer Lejeune, Joseph H. Pendleton, and Smedley D. Butler.

\footnotetext{
${ }^{68}$ Public Affairs Unit 4-1, The Marine Corps Reserve Story, p. 18.

${ }^{69}$ Ibid., p. 19.
} 
President Wilson, on 26 March 1917, officially enlarged the Marine Corps to 693 officers and 17,400 enlisted men. ${ }^{70}$ On 16 April 1917, the newly established Marine Corps Reserve of three officers and 33 enlisted men, was activated nationally. There was virtually no other reserve activity for the balance of the duration, with all recruiting and manpower efforts being focused on active duty mobilization.

The first new 3,600 man regiment to be raised for war service was the 5 th Marines. It consisted of three 1,100 man battalions and a machine gun company. Other regiments rapidly followed, most being organized and staged at the new Marine Corps base in Quantico, Virginia. Because of the reluctance of the Secretaries of War and of the Army to accept Marines for the newly forming American Expeditionary Force, President Wilson took matters into his own hands. On 29 May 1917, the Commander in Chief directed Secretary of the Navy Daniels to have the 5th Marine Regiment ready to proceed with the first convoy sailing for France. On 14 June 1917, the 5th Marines set sail upon the Navy transports Henderson,_Hancock and DeKalb, arriving at St. Nazaire, France on 27 June 1917. Ready and anxious to get on with the war, the Marines were "Over There" and ready to prove themselves. By late 1917, the 6th Marine Regiment had also shipped out for France, combining with the 5th MarineRegiment in early 1918, to form the 4th Marine Brigade of the 2nd Division,

${ }^{70}$ Heinl, Soldiers of the Sea, p. 192. 
Regiment in early 1918 , to form the 4th Marine Brigade of the 2nd Division, American Expeditionary Force. ${ }^{71}$

Among these Marines serving in France, were four known Oregonians. First Sergeant John Albert Page, of Portland, joined the Marine Corps in 1911 and would later retire in 1941 as a Sergeant Major. He was most likely the first Oregonian to arrive in France, serving with the 54th Company, 1st Battalion, 5th Marine Regiment. Of interest is the fact that his company commander was 1st Lieutenant Lemuel Cornick Shepherd Jr., the future 20th Commandant of the Marine Corps (In a 1955 interview, the late General Shepherd spoke highly of Sergeant Major Page). 'The 54th Company, 1st Battalion, 5th Marine Regiment was ordered to France in June 1917, and fought through the battles of Belleau Wood (June 1918), Aisne-Marne (July-August 1918), Saint-Mihiel (September 1918), and Meuse-Argonne (September-November 1918). Described as tall, ramrod straight, and a no-nonsense Marine of the old school who kept his men alive in combat, First Sergeant John Page received the Silver Star and the Purple Heart at Belleau Wood. Following the war, he continued to serve in the Portland Reserve unit up through its activation for World War II (his son, Commander Donald Paige USN, a torpedo bomber pilot, would later receive a Navy Cross for his 1945 participation in the sinking of the Japanese battleship Yamato, off of Okinawa) ${ }^{72}$

${ }^{71}$ Ibid, , p. 195.

${ }^{72}$ Personal Interview between Don N. Dackins and author, Portland, Oregon, 21 March 1994. 
Second Lieutenant Albert Gordon Skelton deployed aboard the U.S.S.Von Steuben on 24 October 1917 from Philadelphia with the 97th Company of the 6th Marine Regiment and arrived in Brest, France on 12 November 1917. He was born in Corvallis, Oregon, on 10 February 1897, and graduated in 1917 from Oregon State University with a degree in civil engineering. Following a brief stint with the Oregon National Guard, he transferred to and was commissioned in the Marine Corps on 27 August 1917 at Quantico, Virginia. For action in France against German forces with the 97th Company, 6th Marine Regiment, he was awarded the Silver Star and Purple Heart medals and the French Croix de Guerre and Fourragere for combat operations at Aisne-Marne (Chateau Thierry), St. Mihiel and the Meuse-Argonne in 1918. Following his temporary promotion to Captain, USMC, on 2 July 1918, he eventually commanded the 97th Company during German occupation duty in Leutesdorf and upon return to Quantico, was discharged on 20 August 1919. Albert Skelton's Croix de Guerre and Silver Star citations recount the following:

"From the 3rd to the 9th of October 1918, near St. Etienne-a-Arnes, his (97th) Company commander having been killed, he has been put in command due to his courage. His bravery and his qualities of leadership has kept up the morale of his men, displayed wonderful leadership in leading their men forward in the attack near St. Etienne, and arriving at their objective, organizing the position and tenaciously clung to it in spite of the utmost the enemy could do to dislodge them. Their resolute courage and cheerfulness contributed in large part to the final success." ${ }^{73}$

${ }^{73}$ Official Military Record of A. G. Skelton, courtesy of National Archives. 
Later, he helped organize the first Marine Corps Reserve unit in 1930, aboard the battleship USS Oregon in Portland and received his permanent promotion to Captain in the USMCR on 13 March 1935. In command of Company F, 11th Battalion, he was still with this unit when it was redesignated 20th Battalion in 1940. Promoted to major, on 13 March 1940, he became the battalion commander. Activated for World War II on 1 November 1940, Major Skelton proceeded with the majority of the Oregon Marine Reserve unit on 7 November 1940 to Marine Barracks, Puget Sound Navy Yard, Bremerton, Washington where the unit later was transferred to San Diego, California for augmentation into regular Fleet Marine Force units. From January 1941 to October 1941, he served as the Executive Officer and Operations Officer (S-3) of the 2nd Engineer Battalion, 2nd Marine Division. Promoted first to Lieutenant Colonel on 8 May 1942 and to Colonel on 5 November 1943, he organized and served throughout the Pacific in charge of the V Amphibious Corps Division of Fleet Marine Force Pacific at Kwajalein, Saipan, Tinian, and Peleliu in 1944 and at Iwo Jima and Okinawa in 1945. He received the Bronze Star Medal for this 1944-1945 service period. He left active duty on 1 March 1946. During the Korean War, Colonel Skelton completed the Amphibious Warfare Course and served on both the Naval Examining and Reserve Policy Boards. Following completion of the Naval War College in Newport, Rhode Island, in 1954 he was eventually promoted to Brigadier General on 14 February 1957. He retired with over thirty years of active and reserve service on 2 March 1957. He was described by those who served with him as a quiet professional who took care of his 
Marines. Having set quite a leadership example as Oregon's first Marine reserve unit commander, infantry officer, combat engineer, and general, he served his nation through World War I, World War II, and the Korean War. He spent his civilian career with the Oregon State Highway Department. General Skelton died on 12 July 1962 in Portland, and was buried in Independence, Oregon. ${ }^{74}$

Sergeant John Corwin Machamer, of Portland, served both with the Marine Detachment aboard the USS North Dakota and in France during World War I. Following the establishment of the Oregon Marine Reserve, he served as the 2 nd platoon commander, in Company F, 11 th Battalion under Major Skelton. Later, when the unit was expanded and redesignated as 20th Battalion, Machamer was promoted to captain and became the commander of Company B. Following the unit's activation and movement to Bremerton, Washington, he served with 2nd Marine Division throughout the Pacific in World War II. Described by those who served with him as an outgoing, dedicated officer, Lieutenant Colonel Machamer later retired from the Marine Corps reserve with 32 years of active and reserve service. His civilian occupation was as a Portland Police Patrolman. ${ }^{75}$

${ }^{74}$ Oregonian, Obituary, Portland, Oregon, 14 July, 1962; Personal Interview between Harry Niehoff, Don Dackins and the author, Portland, Oregon, 21 March 1994.

${ }^{75}$ Oregon Journal, Portland, Oregon, 6 December 1953; Portland Police Department Employment Questionnaire, 15 September 1930. 
One of the most fascinating Marine veterans of World War I is Private First Class Cecil Key, who as of the time of this writing, still lives in Forest Grove, Oregon. Cecil was born on 27 May 1900, and joined the Marine Corps on 17 April 1917. He arrived at Marine Barracks Mare Island, California, for Boot Camp on 7 May 1917 (where he qualified expert on the 1903 Springfield service rifle), and was shipped 7 July 1917 to Quantico, Virginia. While in transit to Quantico, Private Key survived the derailment of his troop train in Cypress, Louisiana. Bivouacked in tents in Quantico (the new barracks were under construction), he also survived an outbreak of dysentery which was traced to flies in the messhall. Prior to going overseas, Private Key remembered meeting Brigadier General John Archer Lejeune, commander of the new Quantico Marine Barracks, who shook his hand and stated: "I hope to see you in France." would General Lejeune soon be serving as his brigade commander in France, but he would also be the first Marine to command an Army division (the 2nd Division), and would further, in June of 1920, become the 13th Commandant of the Marine Corps.

Private Key was assigned as the youngest Marine in the battalion to the 78th Company, 2nd Battalion, 6th Marine Regiment, and his unit sailed on 20 January 1918, from Brooklyn, New York, aboard the USS Henderson. Following debarkation at St. Nazaire, France, on 5 February 1918, he and the 6th Marine Regiment became a part of the 4th Marine Brigade, 2nd Division, American Expeditionary Force. The 2nd Division

${ }^{76}$ Personal Interview between Cecil Key and author, Forest Grove, Oregon, 19 November and 6 December 1993. 
was unique in that as a part of the American Expeditionary Force, it was an "Army" division comprised of the 4th Marine Brigade, the 9th Infantry Regiment, and the 12th Field Artillery Regiment (US Army personnel equipped with French artillery pieces) Despite the "come as you are" appearance of the division, Key stated that "whether Marine or Army, we were all good friends, and no division was ever closer." ${ }^{17}$ Special pride was taken in their "Indianhead" patch. The 4th Marine Brigade, originally called the 4th "Infantry" Brigade by Army officers at AEF headquarters, was with its 280 officers and 9,164 enlisted men, the largest formation of Marines ever fielded up to this time. It was as large as a French division.

The 2nd Battalion, 6th Marine Regiment, like other Marine battalions of World War I, consisted of four 250 man companies. The 78th Company was comprised largely of men from Minnesota, with the rest, like Private Key, coming from the West Coast. The company commander of the 78th was Captain Julius Messersmith, who Key described as a "strict German Jew from Minnesota who knew his job and took care of his Marines. ${ }^{178}$

On the morning of 6 June 1918, at a place called Belleau Wood, the 4th Marine Brigade launched the first major American counterattack of World War I. Private Key moved forward through oats and wheat under both heavy German machine gun and artillery fire. It was here that former Medal of Honor winner, Gunnery Sergeant Daniel

${ }^{77}$ Ibid, 19 November and 6 December 1993.

${ }^{78}$ Ibid., 19 November and 6 December 1993. 
Daly, yelled at his men: "Come on, you sons-of-bitches. Do you want to live forever?"79 By the end of the day, the main German position had been taken. Fighting in the area would continue until 26 June 1918. Clemenceau stated that the Battle of Belleau Wood "saved Paris." 80 The Marine Corps had suffered 1,497 casualties in a single day, the greatest loss in it history. It was a loss not to be matched by Marines in a single day's assault until 20 November 1943, on the beaches of Tarawa.

On 14 June 1918, at Belleau Wood, in the Chateau Thierry sector, Key was blinded and wounded in both legs by shrapnel following a four-hour mustard gas and artillery barrage. Later, two other 78th Company Marines, Corporal John Henry Pruitt and Private John Joseph Kelly (both "good buddies" of Key), received the Congressional Medal of Honor at the Battle of Blanc Mont Ridge. Pruitt was killed by German shellfire. Key regained his sight after three months, but remained hospitalized until the second week of November, when he rejoined the 78th Company in the Argonne Forest of northeast France. This was in time to observe the 11 th hour of the 11 th day of the 11 th month: the armistice and end of World War I. Of the 250 original Marines in Key's 78th Company, only 59 returned home. Throughout 1918, an additional 680 Marine replacements had been augmented into the 78th to maintain its combat capability.

${ }^{79}$ Heinl, Soldiers of the Sea, p. 201.

${ }^{80}$ Ibid., p. 202. 

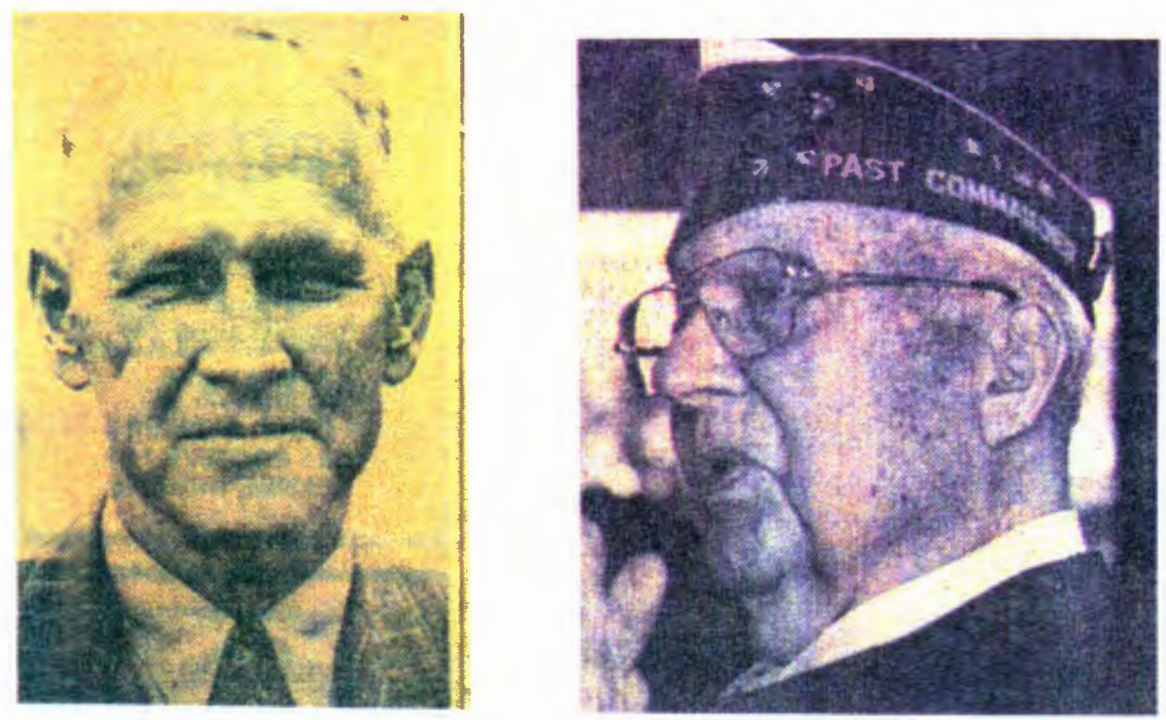

Figure 10 (left): Albert G. Skelton, United States Marine Corps Reserve, was born in Corvallis, Oregon, on 10 February 1897 and died in Portland on 12 July 1962. An engineering major and graduate of Oregon State University, he fought in France in World War I, where he earned a Silver Star, a Purple Heart and the French Croix de Guerre with the 97th Company, 6th Marine Regiment. He played a crucial role in organizing in 1930, and later commanding, the first Marine Corps Reserve unit in Oregon: Company F, 11 th Battalion, which drilled aboard the USS Oregon. He also served during World War II, where he earned a Bronze Star, and the Korean War. He retired as a Brigadier General in 1957.

\section{Photo courtesy of Harry H.W Niehoff Collection}

Figure 11 (right): Cecil Key, of Forest Grove, was born on 27 May 1900. He served with the 78th Company, 2nd Battalion, 6th Marine Regiment at Belleau Wood, where he eamed a Purple Heart in a German gas attack. He left the Marine Corps as a Private First Class following the war and is now Oregon's last surviving Belleau Wood veteran.

Photo courtesy of Cecil Key Collection 
All told, Key served in France, Belgium, Luxembourg, and Germany, from Verdun (15 March to 14 May 1918), to the Aisne Defensive (31 May to 5 June 1918), to Chateau Thierry and Belleau Wood (6 June to 8 July 1918), the March to the Rhine (17 November to 12 December 1918), to Army of Occupation duty in Germany (13 December 1918 to 4 July 1919). Given the distinguished combat record of the 2nd Division and the hope that they would be among the first sent home, extended occupation duty in Germany was his most bitter memory. Aside from the comraderie and friendship that he developed with his fellow Marines, one of his best Marine memories was returning to New York on the USS George Washington with some 200 Army nurses on board. Private First Class Cecil Key was Honorably Discharged from the Marine Corps back in Quantico, Virginia, on 13 August $1919 .{ }^{81}$ He would spend the next 51 years working for the Northern and Union Pacific Railroads, and then enjoy his well-deserved retirement in Forest Grove, speaking to Oregon school children and fellow Marines on history.

Belleau Wood was more than just a personal experience for men such as Lieutenant Albert Skelton and Private Cecil Key, for it constituted a real turning point in Marine Corps history. For most of its previous 142 years, Marines had spent most of their time focused on small expeditions and actions against second rate or native enemies. Belleau Wood represented large scale formations of Marines confronting an experienced,

${ }^{81}$ Military Record, Discharge Papers, PFC Cecil Key, Forest Grove, Oregon, 19 November and 6 December 1993. 


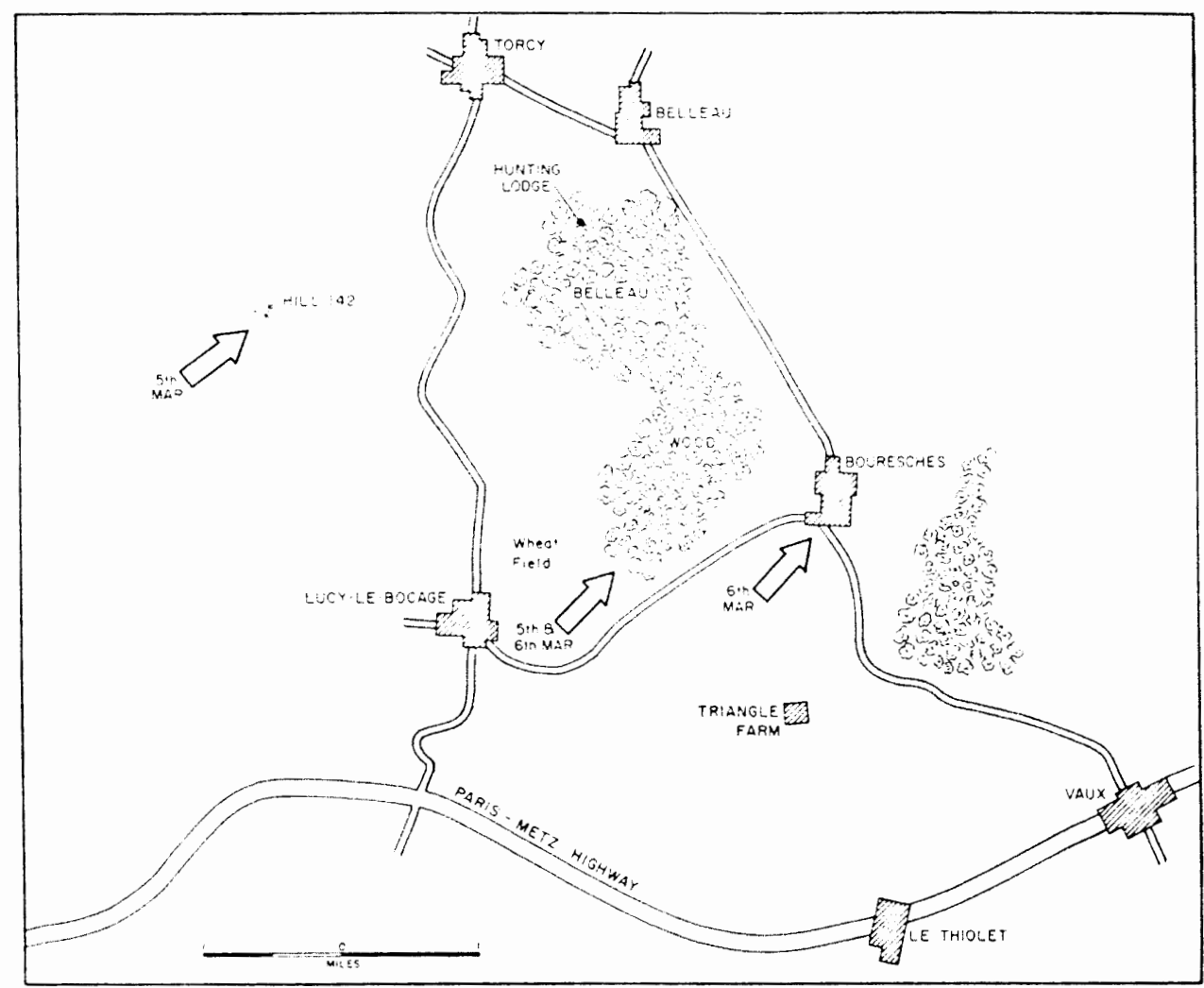

Battle of Belleau Wood, 6-26 June 1918.

Figure 12: Large scale map of Belleau Wood, France, June 1918.

Soldiers of the Sea by Heinl, p. 200. 


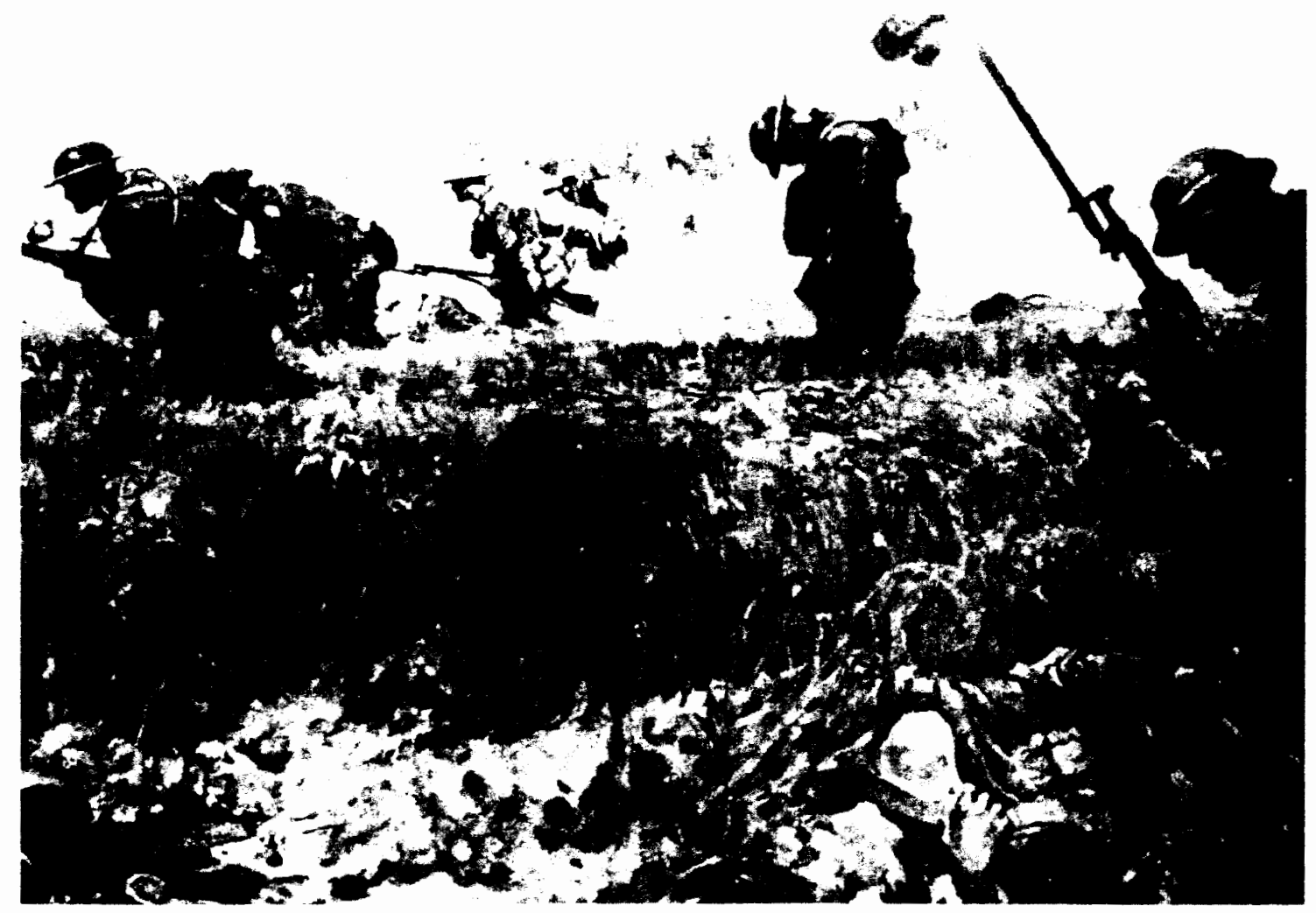

Figure 13: On 6 June 1918, following the blunting of the last German offensive on Paris, the 5th and 6th Marine Regiments attacked heavily defended German positions at Belleau Wood. Despite 1,087 casualties (a 50\% attrition rate), the Marines carried the day. It would be 20 November 1943, on the beaches of Tarawa, before Marines again sustained such heavy casualties in a single day's assault.

Soldiers of the Sea by Heinl, p. 206. 


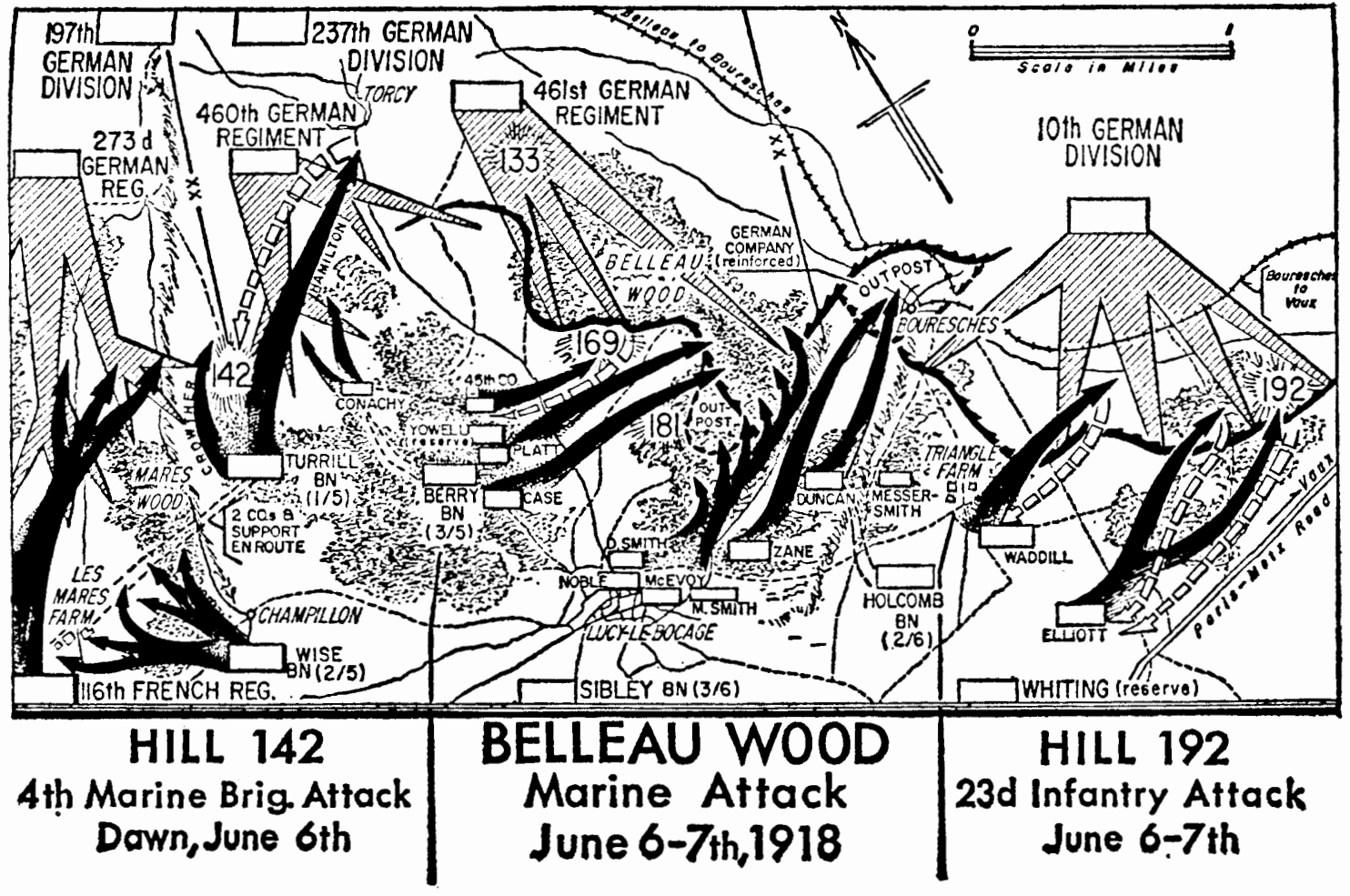

Figure 14: Detailed map of Battle of Belleau Wood, which shows actual positions of small units such as Private First Class Cecil Key's 78th Company, 2nd Battalion, 6th Marine Regiment, which was commanded by Captian Julius Messersmith. Key, of Forest Grove, Oregon, is Oregon's last surviving World War I Marine veteran.

At Belleau Wood by Robert B. Asprey, G.P. Putnam's Sons, New York, 1965, p. 163. 


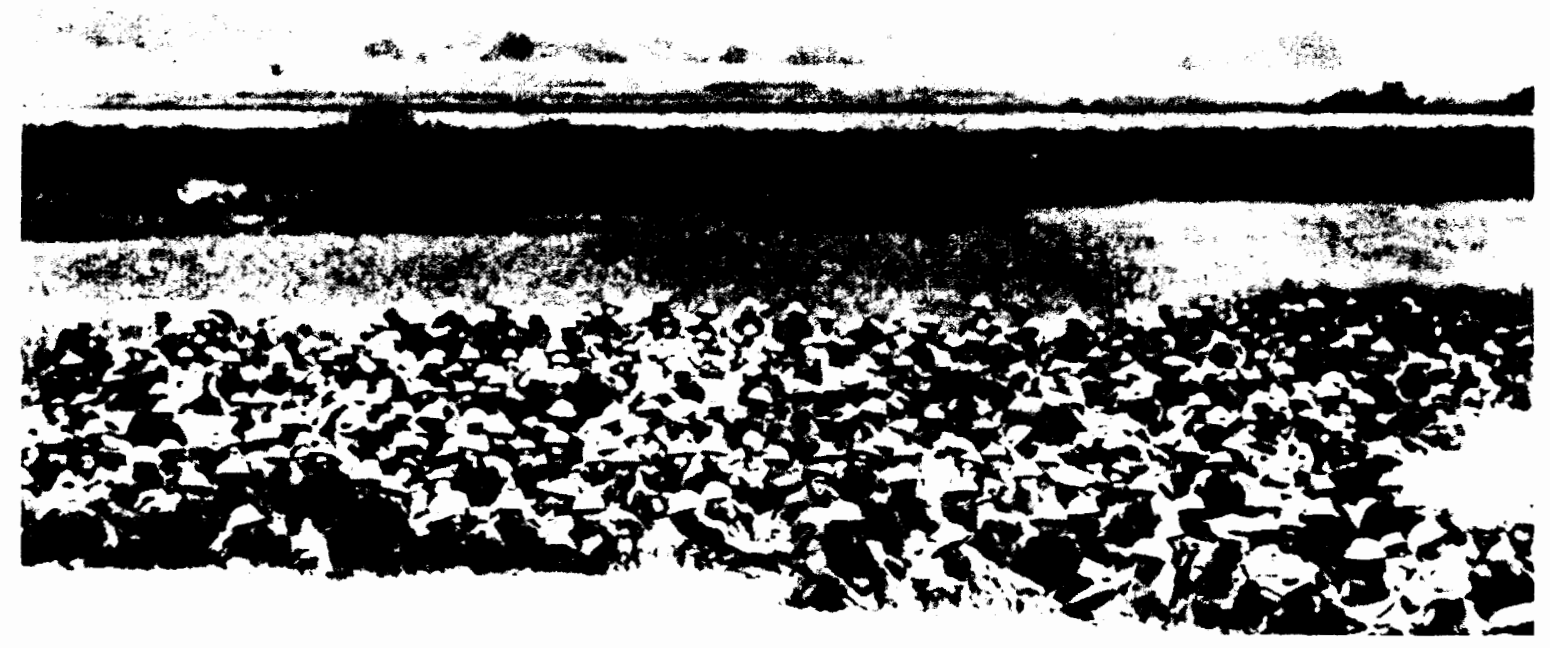

Figure 15: Remnants of Major Thomas Holcomb's 2nd Battalion, 6th Marine Regiment, of which Private First Class Cecil Key's 78th Company was a part. This photo was taken during a break while the unit moved to the rear following Belleau Wood. The battalion originally numbered 1,100 Marines. The 4th Marine Brigade (5th and 6th Marine Regiments) as a whole suffered $55 \%$ casualties at Belleau Wood.

Soldiers of the Sea by Heinl, p. 206. 
determined German army equipped and supported with an extensive array of modern weapons. Between 6 and 26 June 1918, 4,677 Marines had been killed and wounded. But with a solid tradition behind them of leadership by example, courage, discipline, and small unit initiative, Marines had defeated their most challenging enemy. German intelligence had its own verdict, stating that:

"The 2nd American Division must be considered a very good one, and may perhaps even be reckoned as storm troops. The different attacks on Belleau Wood were carried out with bravery and dash. The moral effect of our gunfire cannot seriously impede the advance of the American riflemen." 82

Belleau Wood and the battles that followed reinforced these basic Marine Corps leadership values. Many Marine officers and men learned a lot in a hurry about a new kind of war. This was to influence and shape the thinking, training, organization, and spirit of the Marine Corps in the years ahead.

At the end of World War I, the Marine Corps had grown to a strength of 79,524, of which 32,366 had served in France. Total casualties were 11,366, of which 2,459 were killed or missing in action. Twelve Medals of Honor had been earned. By 1919, the Marine Corps had been reduced to 17,400 men, which was approximately its prewar strength. In Oregon, the main focus of Marine Corps activity remained the Recruiting Station in downtown Portland. Marine veterans such as Albert Skelton, John Machamer, John Page, and Cecil Key settled back down into civilian life.

\footnotetext{
${ }^{82}$ Heinl, Soldiers of the Sea, p. 204.
} 
The 1920's were a period of drastic reductions in defense spending, and the Marine Corps was hard pressed to maintain its three new major bases (Quantico, Virginia, Parris Island, South Carolina, and San Diego, California) and its manpower level, on a limited budget. These factors, coupled with concerns over the availability of regional manpower, further delayed the establishment of an Oregon reserve program. As a result of this near fiscal starvation, the Marine Corps Reserve almost died in the early 1920's. It would again be practically broke in the depression years of 1929 to 1933 . During these lean years, many Marine Reserve units drilled and trained without pay. ${ }^{83}$

The decade of the 1920's did involve two interesting events which involved and impacted Marines in Oregon. The first occurred on 11 November 1921, when Secretary of the Navy Edwin Denby (World War I Marine veteran), issued an unusual order based upon the direction of President Harding. The country was in the grip of a crime wave which focused on armed robberies of the U.S. Mail. The President instructed the Marine Corps to "protect the mails from depredations by robbers and bandits. " ${ }^{84}$ The Marine Corps deployed 53 officers and 2,200 fully armed enlisted men across the country (to include Oregon) in post offices, railway mail cars, and postal trucks. Their orders from Secretary Denby, who needed no ghost writer, explicitly directed that " . . if attacked, shoot and shoot to kill." 85 Across America, mail robberies came to an abrupt halt. Not

${ }^{83} \underline{\text { Ibid., p. }} 298$.

${ }^{84}$ Ibid., p. 252.

${ }^{85}$ Ibid., p. 251. 
one confrontation took place involving Marines, and not one piece of mail was lost during this four-month period. Later, in October of 1926, a replay of this event took place with the same prompt results. This time, the problem did not recur.

Meanwhile, in 1925, the state of Oregon officially petitioned the United States Government and the Department of the Navy with an unusual request. This was to have the Spanish-American War era battleship USS Oregon berthed in Portland as a memorial and preserved from planned scrapping under the terms of the 1921-22 Washington Naval Treaty. On 3 July 1925, the anniversary of the 1898 Battle of Santiago, the governor of Oregon officially accepted the ship from the Navy Department upon her arrival at the annual Portland Rose Festival. Anchored first at the northeast end of the Broadway Bridge, the USS Oregon was later towed and moored at the southwest end of the Hawthorne Bridge ${ }^{86}$ Here, in 1930, at the foot of Columbia Street, the veteran battleship appropriately became the home of Oregon's first United States Marine Corps Reserve unit.

Designated as a Marine infantry unit with the name Company F, 11th Battalion, it was only appropriate that the first commander be the individual who had worked hardest at establishing this 125 man unit: Captain Albert G. Skelton USMCR, distinguished veteran of World War I. The state of Oregon now had an official Marine Corps Reserve unit, a program actively supported by the local Marine Recruiters, and a 1977), p. 132.

${ }^{86}$ Sternlicht, Sanford McKinley's Bulldog: The Battleship Oregon, (Chicago, 


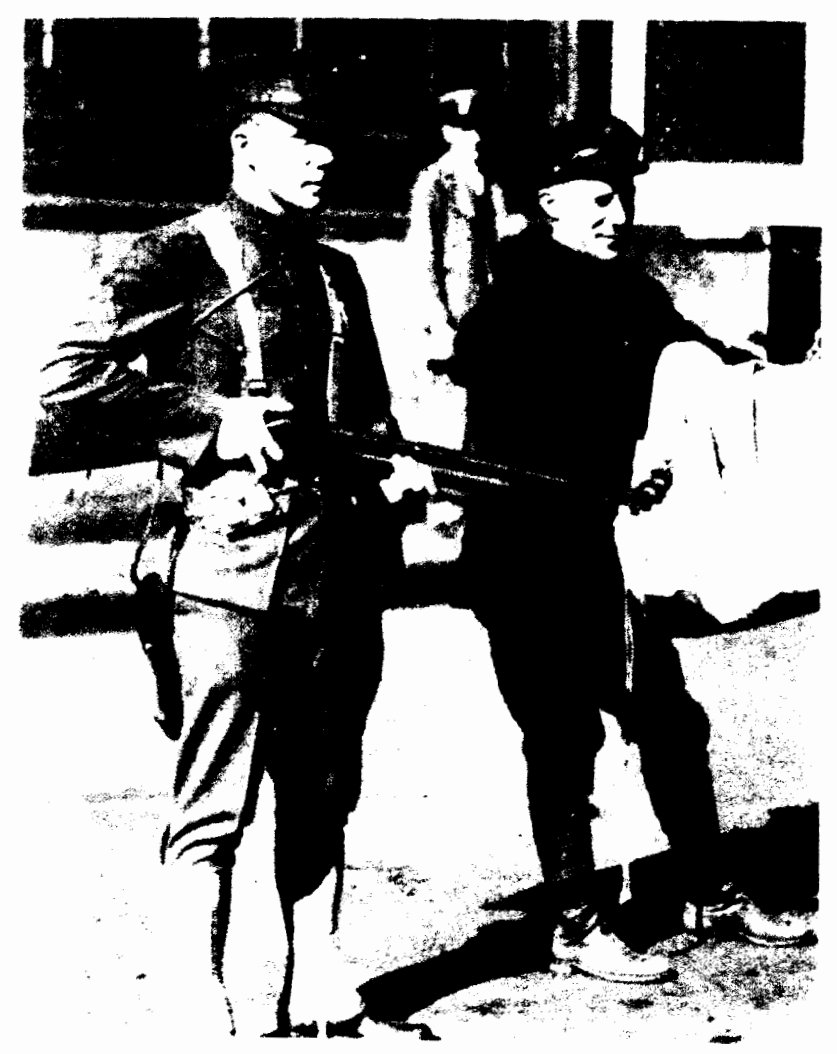

Figure 16: United States Marines guarded the U.S. Mail from banditry in 1921 and 1926. Their area included Oregon. Secretary of the Navy Denby ordered that: "If attacked, shoot, and shoot to kill." It was reported that not a piece of mail was lost while Marines stood watch.

Soldiers of the Sea by Heinl, p. 270. 


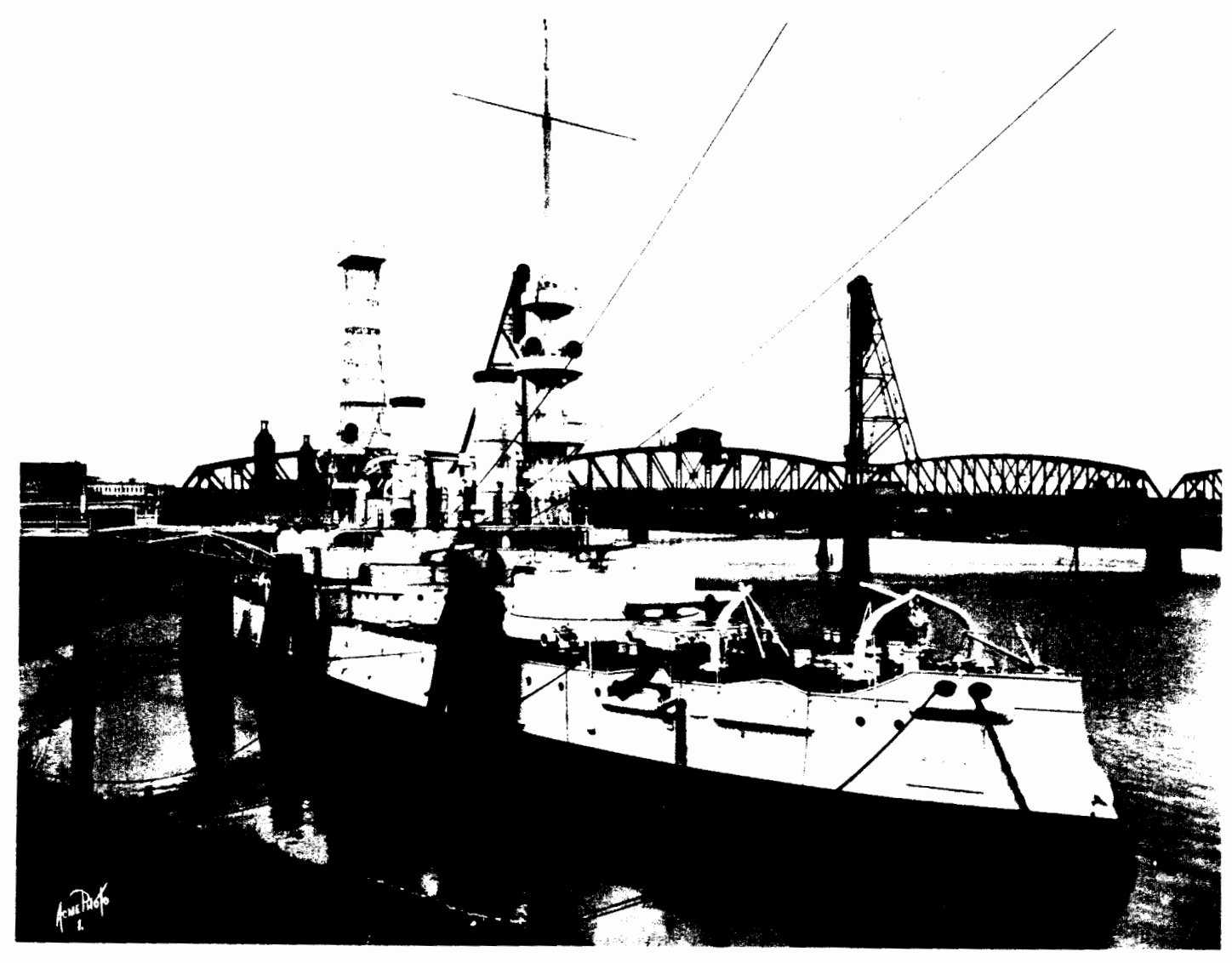

Figure 17: Spanish-American War era battleship LSS Oregon berthed as a memorial at the foot of Columbia Street in Portland. On 3 July 1925, the Governor of Oregon accepted her on loan from the United States Navy. Here, in 1930, the first organized Marine Corps Reserve unit in Oregon was established: Company F, 11th Battalion (Marine Infantry)

Photo courtesy of Oregon Historical Society (\#1459) 


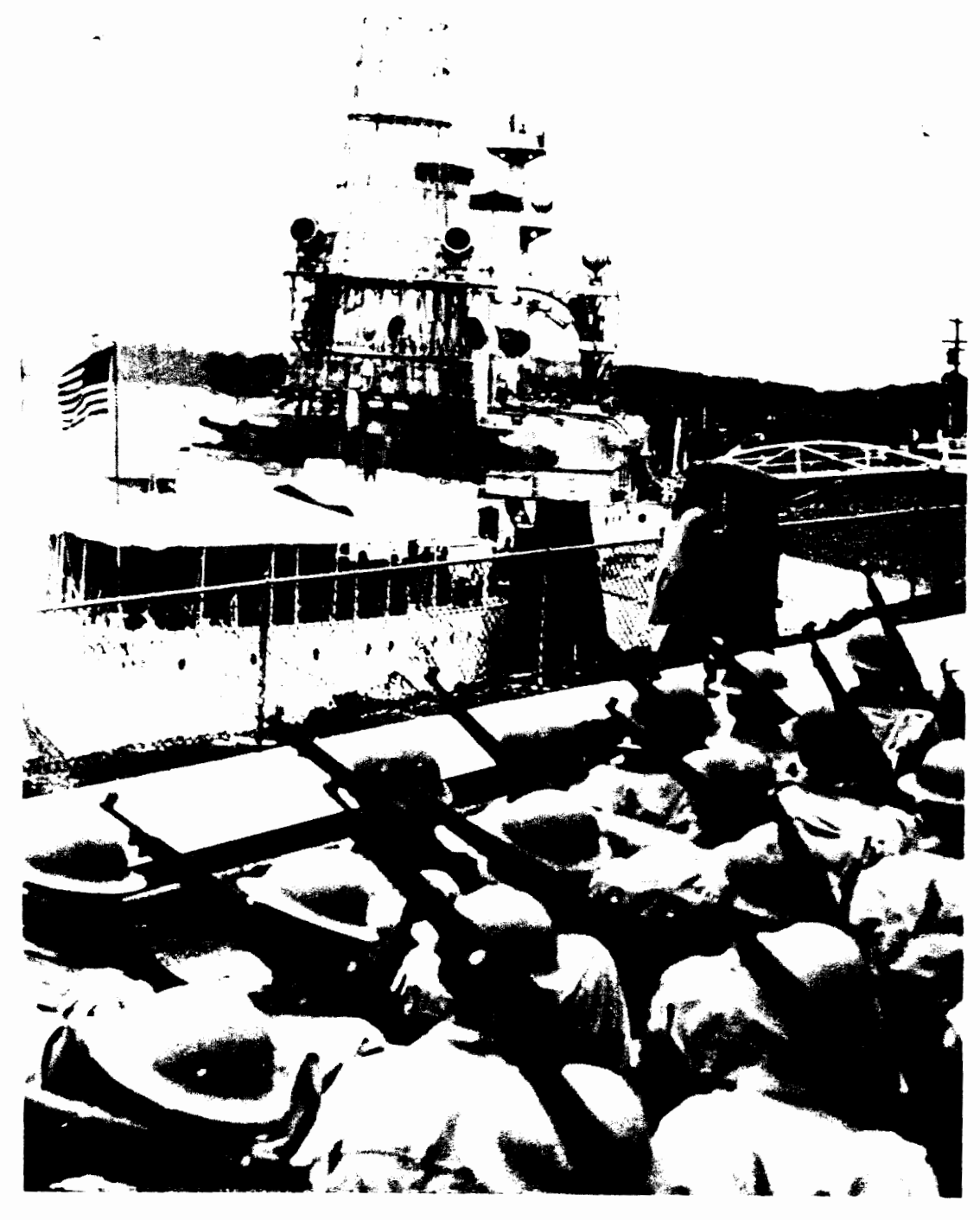

Figure 18: Marine Reserve infantry of Company F, 11 th Battalion, drill just north of the battleship USS Oregon in 1939. Here they march south between the ship and the base of Columbia Street with their 1903 Springfield rifles and World War I helmets. In 1940, the unit expanded and was redesignated as the 20th Battalion. The unit was activated for World War II in November 1940. Tragically, the USS Oregon was sold for war scrap in December 1942.

Photo courtesy of Qregen Historical Society (\#12095) 
valid mission of augmenting and reinforcing the regular Fleet Marine Force. Formally established in 1933, the FMF constitutes the bulk of Marines assigned to the operating forces of the Navy.

Despite the establishment of Company F, 11 th Battalion, in Portland, and the continued success of Marine expeditionary forces throughout far-flung areas of the globe, these were tough economic times for both the nation and the Marine Corps. In 1931, the enlisted strength of the Marine Corps stood at 18,000 men. By 1933, this was cut to 15,343

Much of the credit for the continued existence of the Marine Corps in the face of repeated Army attempts to have it disbanded, goes to General Lejeune. Not only was he an outstanding combat commander and beloved leader, but he was also a man of superb intelligence and vision. Despite the triumphs of World War I and the popularity of the Marine Corps with the general public and Congress, Lejeune and those who followed him realized that the perennial mission of the Marine Corps was readiness. This attribute, coupled with the standard Marine emphasis on leadership, esprit, and initiative, was the single most important common denominator throughout Marine Corps history. Readiness was certainly a unique mission, as America had rarely had a standing army. Historically, the accepted missions of the Army had been those of routine garrison and of maintaining a cadre for mobilization in times of conflict.

Lejeune understood that readiness meant not lapsing into a resumption of the prewar role of Marines as lightly armed forces of occupation and pacification. This role 
as "European colonial infantry" could not continue for time was running out. By 1920 , America was a powerful maritime nation which faced several potential challenges for mastery of the seas. In naval warfare, readiness meant one thing in particular to Lejeune's Marines: the ability to project expeditions overseas to seize and secure advance bases. The Marine Corps, despite its small size, focused throughout the 1920's and 1930's on amphibious warfare readiness and capability. This was the central reason for the existence of a Corps which had in the 140 years leading up to World War II, made 180 armed Marine landings in 37 countries.

With basic sound tactical doctrines in place, the importance of a capable Marine Corps Reserve grew. By 1935, the firm financial footing of the organized and volunteer Reserve had resulted in a total of 9,061 officers and men. The entire Reserve organization consisted of 13 battalions spread out over key cities.

The Marine Corps and its Reserve would soon be girding for war. 


\section{CHAPTER V}

\section{WORLD WAR II: THE SUPREME TEST}

"The Japanese attacked little Wake the day of Pearl Harbor, first with devastating bombing and subsequently with substantial naval and ground forces. Immediately, this obscure atoll became a symbol of national tragedy and individual glory. The pathetically small garrison, by holding out for fourteen historic days, and in inflicting tremendous losses on the enemy, gave to the American spirit the kick that it needed. Our people gained the will to fight and the confidence in our ability to fight, and this was done, literally 'with the help of God and a few Marines.. ${ }^{187}$

Robert E. Sherwood

Preface: The Story of Wake Island, 1947

"The Marines' Hymn bit so deep into my memory that I could not get it out. ${ }^{\text {'88 }}$

Winston Churchill

Taking the salute from the 1st Marine

Brigade, Iceland, 16 August 1941

"The raising of that flag on Suribachi means a Marine Corps for the next 500 years. ${ }^{189}$

James Forrestal, Secretary of the Navy, to LtGen H. M. Smith USMC, as Marines raised Colors over Iwo Jima, 23 February 1945

${ }^{87}$ James P. S. Devereux, The Story of Wake Island, (New York, 1947), p. 12.

${ }^{88}$ Heinl, Soldiers of the Sea, p. 366, photo \#1.

${ }^{89}$ Robert Debs Heinl, Jr., Dictionary of Military and Naval Quotations, (Annapolis, 1966), p. 184. 
"Uncommon valor was a common virtue. ${ }^{100}$

Fleet Admiral C. W. Nimitz, Communique \#300, Subject: Marines on Iwo Jima 14 March 1945

On 1 September 1939, the German Army overran Poland and initiated World War II. Two days later, United States Marine Corps strength was reported at 1,354 officers and 18,052 enlisted Marines. A week later, President Roosevelt proclaimed a state of limited national emergency, increasing the strength of the Marine Corps to $25,0000^{91}$

The initial 1939 expansion included the first volunteer reservists for mobilization. These were 114 junior officers, who represented the first dividends of the new Platoon Leaders' Class program at Quantico, Virginia. This highly successful program, which allows officer candidates to attend the college of their choice, exists to this day.

Meanwhile, the Portland Marines of Company F, 11 th Battalion, continued to meet one night a week aboard the battleship USS Qregon. The 1939 to 1940 personnel roster lists 105 Marines in the unit. Still under the command of now Major Albert G. Skelton, an engineer with the Oregon Highway Department in Portland, the first platoon was commanded by Captain Lloyd E. Wagner, a Portland attorney, while the second platoon was lead by Captain John C. Machamer, a Portland policeman. As experienced

${ }^{90}$ Ibid., p. 492.

${ }^{91}$ Heinl, Soldiers of the Sea, p. 661. 
World War I veterans, Skelton and Machamer understood the importance of readiness. They complemented each other and strengthened the unit with their different leadership styles. Skelton was the quiet, focused professional who emphasized attention to detail; Machamer, the outgoing, involved enthusiast who easily identified with and nurtured junior Marines.

During the summer of 1940 , the unit expanded and was redesignated as the 20 th Battalion. Major Skeiton became the battalion commander, while Captains Wagner and Machamer became the company commanders for Companies A and B. The unit made use of additional space at the Marine Corps Reserve Armory at the Portland Public Market. The final two week annual training period for 1940 took place from 16 to 30 June at Marine Barracks, Puget Sound Navy Yard, Bremerton, Washington. With war on the horizon, the planned review of basic infantry skills was a sound training goal for all Marines.

On 15 October 1940, general mobilization orders followed for the entire Organized Marine Reserve, which stood at 236 officers and 5,009 enlisted men. On 7 November 1940, Portland's 20th Battalion was mobilized, being given orders to proceed to Marine Barracks, Puget Sound Naval Yard. The muster roll for Company A showed a strength of 1 officer and 49 Marines, Company B of 1 officer and 51 Marines, and Company $\mathrm{C}$ of 1 officer and 36 Marines. In March 1941, most of these Oregon Marines boarded the USS Heywood in Puget Sound, and headed south for San Diego. They 
arrived on 1 April 1941, where on the following day, the individual companies which had comprised Portland's 20th Battalion were disbanded and integrated into regular units. ${ }^{92}$

The Marine Corps was experiencing explosive growth. On 1 February 1941, aboard the battleship USS Texas off of Guantanamo Bay, Cuba, the 1st Marine Division was created. The unit was placed under the very able and capable command of Major General Holland McTyeire "Howlin Mad" Smith. A 5th Marine Regiment veteran of World War I, Smith would later work closely with Admiral Chester W. Nimitz in planning every Marine assault operation in the central Pacific, and he would personally lead Marines ashore at Tarawa, Saipan, and Iwo Jima. On the same day, in San Diego, California, the 2nd Marine Division was also established. By mid-1941, there were 53,886 Marines in uniform.

On 7 December 1941, Marine Reservists, combined with their active duty counterparts, gave the Marine Corps a total strength of 66,319 officers and men. By the end of December 1941, strength was at 70,425 or just 4,000 short of the previous World War I all-time peak.

It should be noted that no Marine Reserve unit was ever mobilized and put intact on active service. Though confusing at first, the wisdom of this Marine Corps policy became readily apparent as units rapidly became integrated into stronger, more diversified teams. To the Commandant of the Marine Corps, Lieutenant General Thomas Holcomb, it was important to emphasize that there was room in the Marine Corps for

${ }^{92}$ Oregonian, (Portland, 4 May 1941.) 


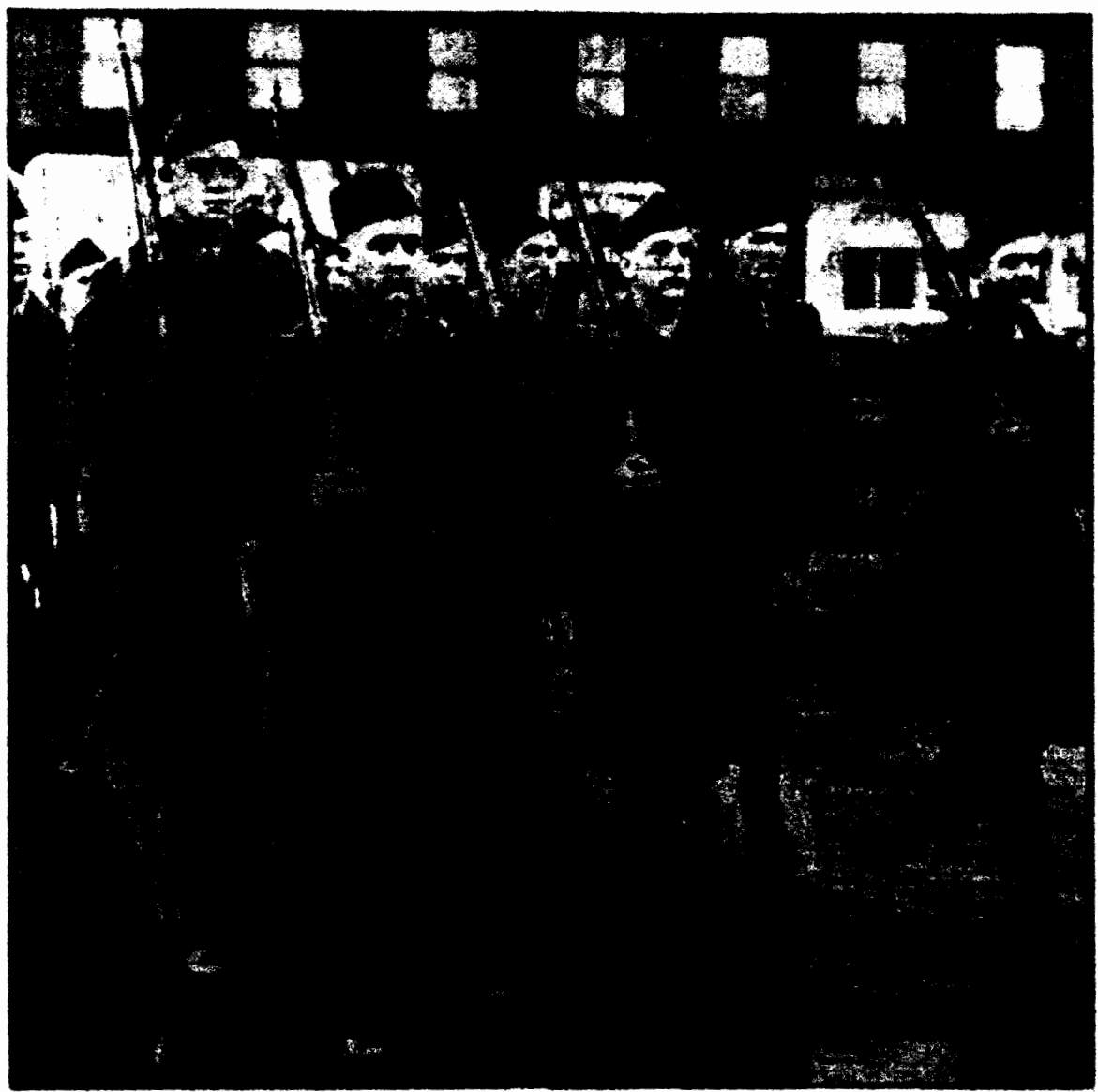

Figure 19: In November 1940, the Marine Reserve infantry of 20th Battalion were activated and deployed to the Navy Yard in Bremerton. Washington. From here, the unit sailed to San Diego, California, where 20th Battalion was disbanded. Many of these Marines joined the newly formed 2nd Marine Division, and fought against the Japanese in the Pacific.

Photo courtesy of Harry $\mathrm{HW}$ Niehoff Collection 
only one kind of Marine. Once mobilization was completed, he directed that the " $\mathrm{R}$ " be dropped from reservists' designations so that all hands were USMC ${ }^{93}$

By the fall of 1940, as Reserve Battalions lost their identity in augmenting larger regular units, the history of the Marine Corps Reserve passed into a state of hibernation until after World War II. In Portland, following the departure of the 20th Battalion on 7 November 1940, Major James B. Hardie of the Portland Recruiting Station became the primary Marine Corps representative in Oregon.

No one individual Marine story better represents the contribution Oregon made to the Second World War effort than Private First Class Harry H. W. Niehoff, of Portland. His story is in a way the story of the Pacific war itself.

Originally having joined Company F, 11 th Battalion, aboard the USS Oregen on 3 April 1940, Niehoff was transferred to 2nd Platoon, Company A, 2nd Engineer Battalion of the newly formed 2nd Marine Division. On 29 October 1941, following training at Camp Elliott, San Diego, as a combat engineer, Niehoff and 2nd Engineer Battalion were deployed to Pearl Harbor, Hawaii, aboard the USS Wharton to construct Camp Salt Lake. Later renamed Camp Catlin, this project was just northwest of Honolulu, and relatively close to the Marine Barracks, Pearl Harbor, where Niehoff and his unit were billeted on the parade deck in tents. During the 7 December 1941 attack, Niehoff expended three magazines of 30 calibre Browning Automatic Rifle (BAR) fire at various Japanese planes which were strafing Hickam Airfield. Following deployments

\footnotetext{
${ }^{93}$ Heinl, Soldiers of the Sea, p. 307.
} 


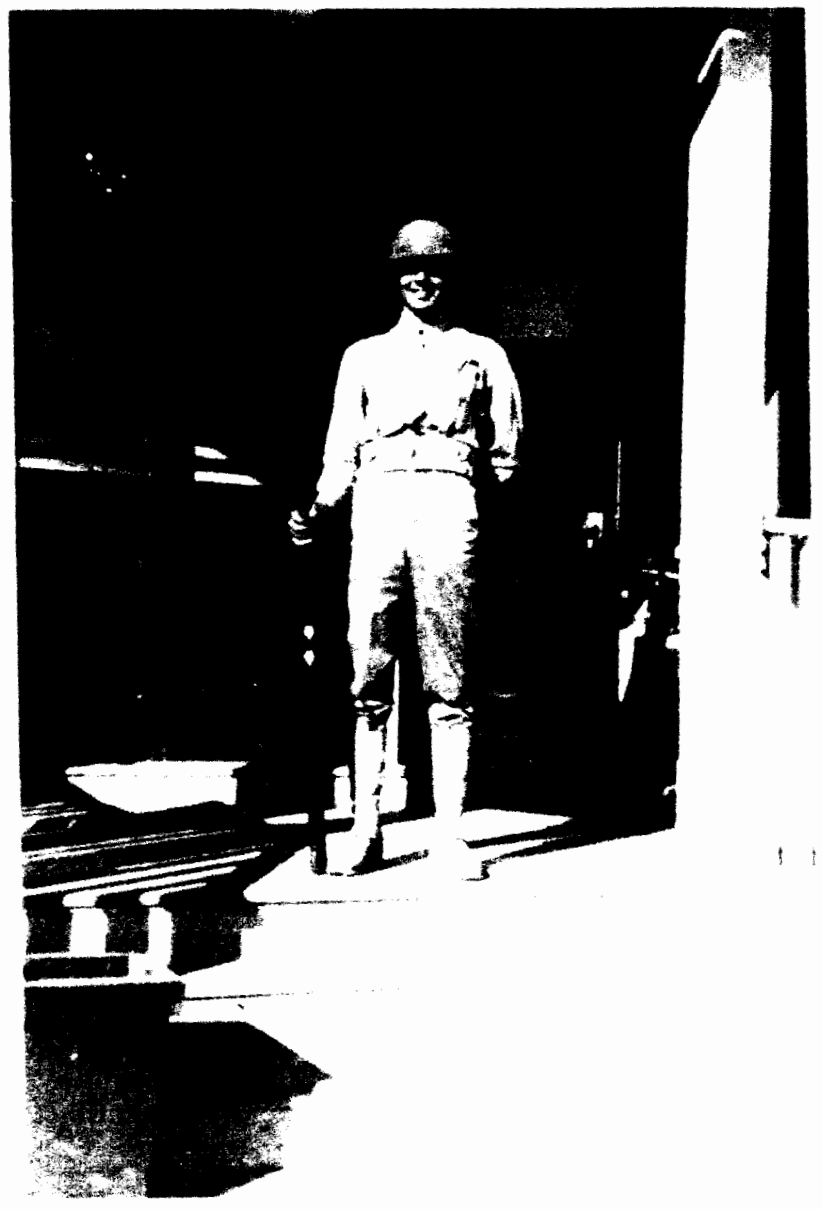

Figure 20: Private Harry H.W. Niehoff, of Portland, who joined the "Oregon Marines" of Company F, 11 th Battalion in 1939. Here he poses at the Navy Yard in Bremerton, Washington, following the 1940 activation. He was soon assigned in San Diego to Company A, 2nd Engineer Battalion, 2nd Marine Divison.

Photo courtesy of Harry H.W. Niehoff Collection 

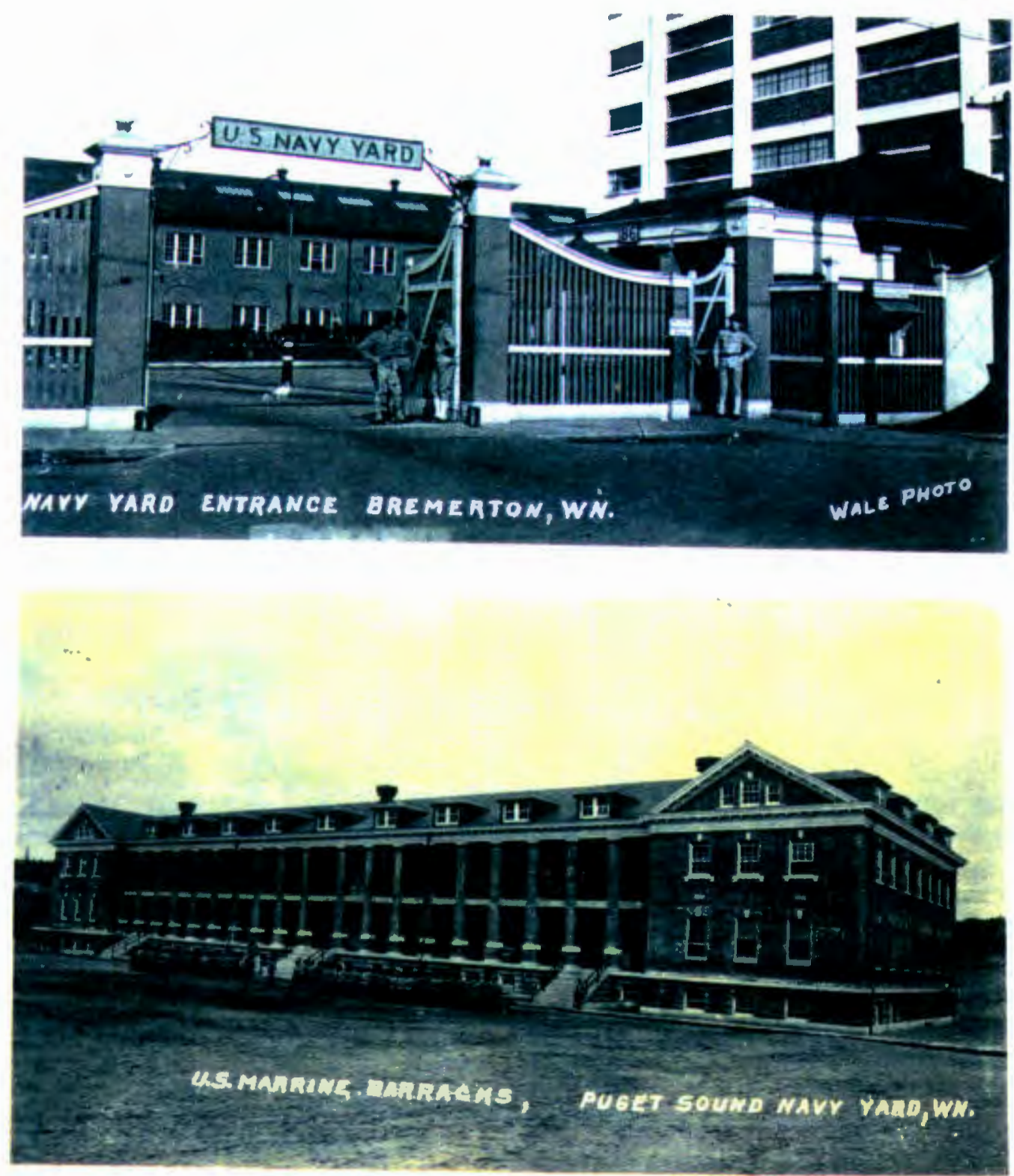

Figure 21 (top): Marines on duty, Navy Yard, Bremerton, Washington. This is where Oregon Reserve Marines were initially sent following activation.

Figure 22 (bottom): Marine Barracks, Puget Sound Navy Yard, Washington.

Photos courtesy of Harry $\mathrm{H} . \mathrm{W}$. Niehoff Collection 
to Espirito Santos and Wellington, New Zealand, Niehoff landed with his same unit from the USS Heywood, on 20 November 1943, on Red Beach 3 of Tarawa. They were in support of the hard pressed 2nd Battalion, 8th Marine Regiment, of 2nd Marine Division. Fighting alongside 1st Lieutenant Alexander Bonnyman Jr., who was killed in action and earned a Medal of Honor, Niehoff operated for the next 76 hours straight with a 11-man engineer squad, divided into two five-man teams. Each engineer team was comprised of three demolition men, and a two-man crew with a flamethrower (the assistant flame thrower man carried extra fuel and a shotgun). As a demolition man, Niehoff utilized charges consisting of four $1 / 4$ pound blocks of TNT, and when this was expended by the third day, employed sensitive commercial dynamite to blast apart Japanese bunkers. Standard fusing was for a mere 4-5 seconds, otherwise, the Japanese would "return" the explosives. "Blind 'em, burn 'em, blast 'em" was the technique and engineer order of the day of first obscuring the enemy with smoke, then keeping him pinned down by the flame thrower, and then manually tossing the demolition charge into his bunker. It was a desperate battle of attrition in which Marine teamwork and courage painstakingly eliminated the stubborn Japanese defense. Infantry covering fire was crucial in supporting these combat engineer assaults. For his "conspicuous gallantry and intrepidity" in repeatedly destroying Japanese bunkers with his demolition charges, while all the time under intense enemy fire, Corporal Niehoff was awarded the Silver Star. In the summer of 1944, he received a Bronze Star for similar exploits on Saipan and Tinian in the Mariana Islands, where plastic explosive now replaced the TNT charges. Speaking 

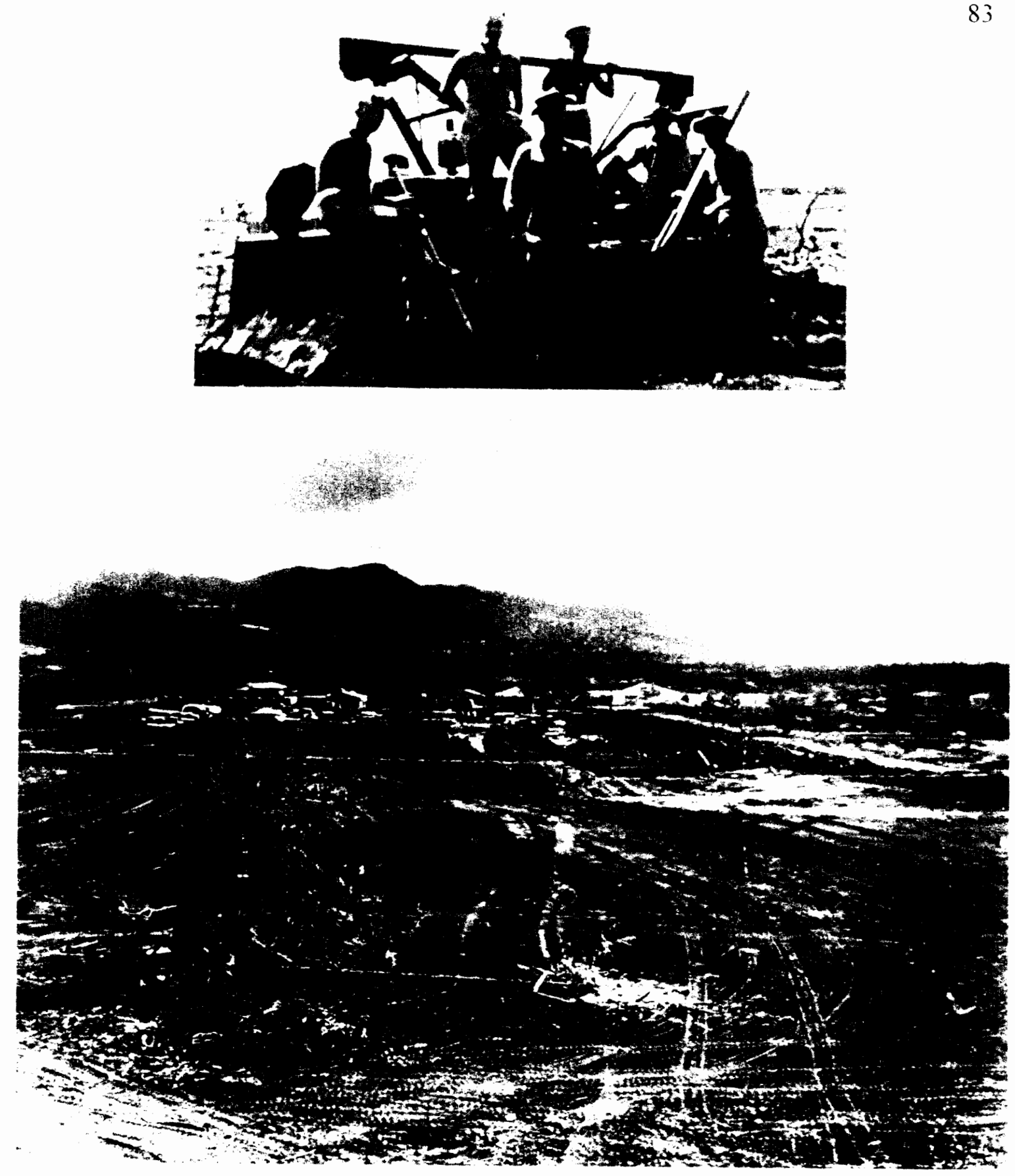

Figure 23 \& 24: Sergeant Harry H.W. Niehoff, of Portland, and Marines of 2nd Engineer Battalion at work on Camp Salt Lake (later Camp Catlin), Oahu, two weeks prior to attack on Pearl Harbor.

Photos courtesy of Harry H.W. Niehoff Collection 


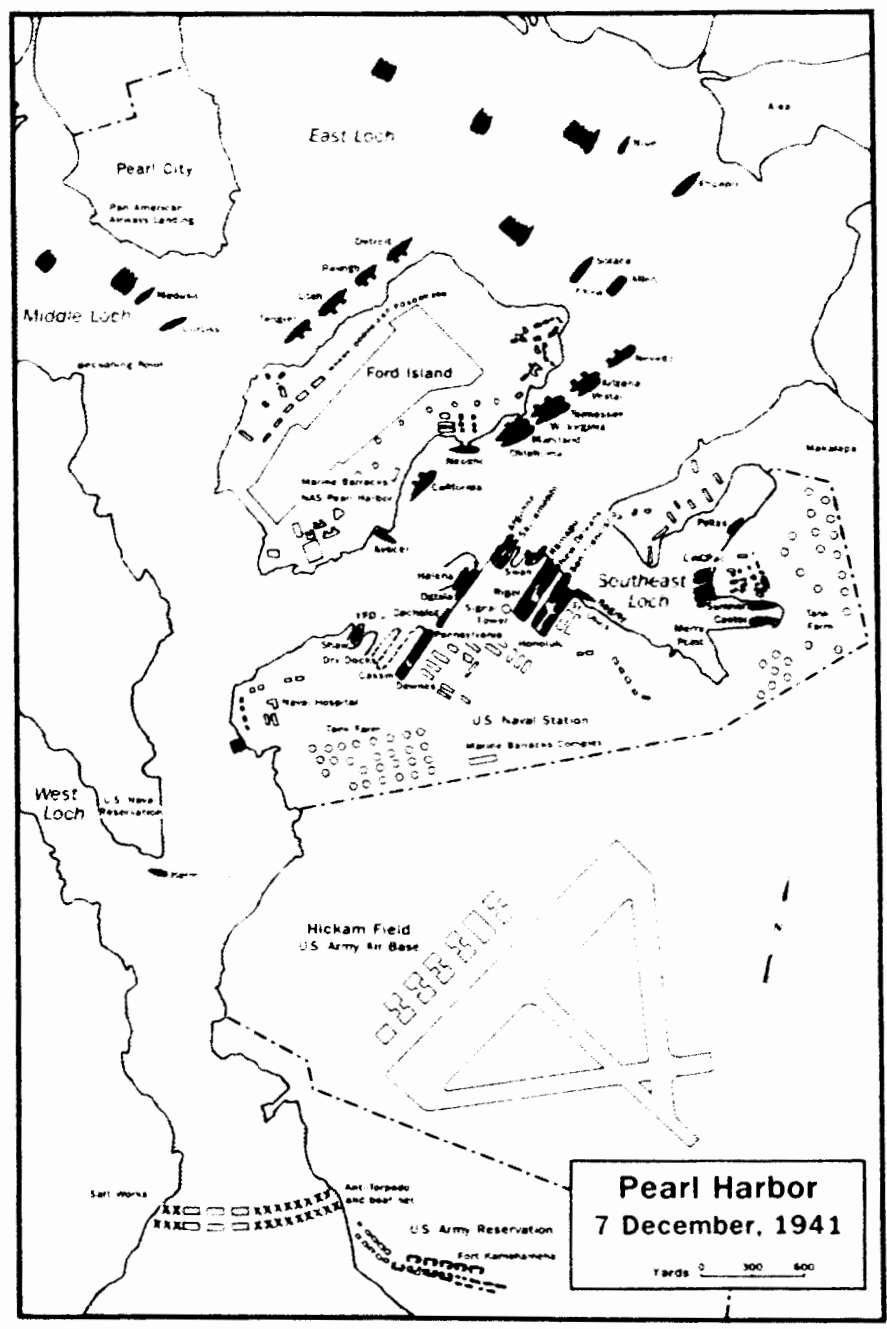

Figure 25: Map of Pearl Harbor, Hawaii, 7 December 1941, showing location of Marine Barracks, where Harry H.W. Niehoff of Portland was billeted. Also location of USS Honolulu where Carl V. Larsen of Lebanon was on duty at time of attack.

Photo courtesy of United States Naval Institute 


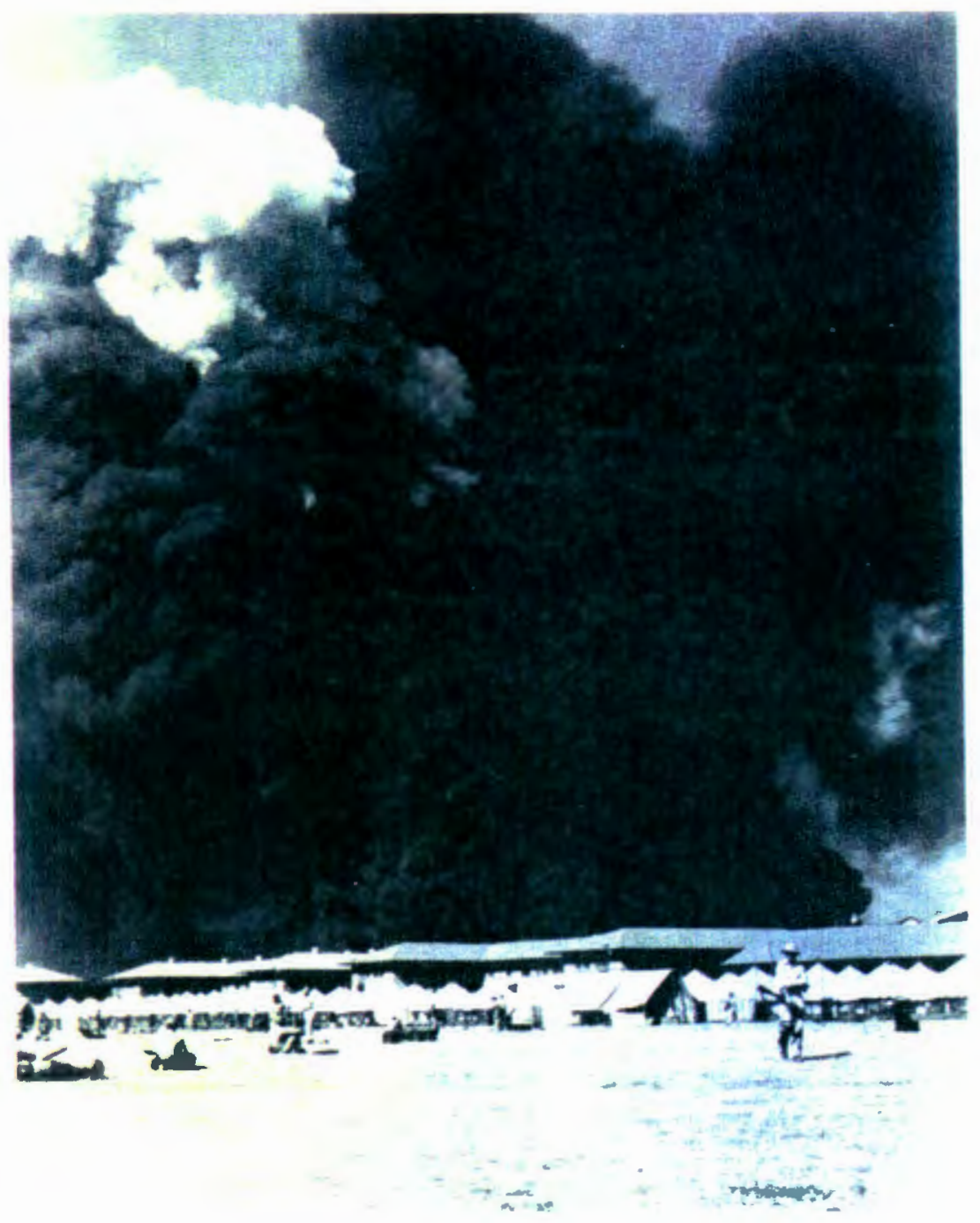

Figure 26: The Marine Barracks and additional billeting tents on the parade ground at Pearl Harbor, Hawaii during the Japanese attack. Note smoke from burning ships and harbor facilities. Harry H.W. Niehoff of Portland, was billeted among these tents with Company A, 2nd Engineer Battalion.

Photo courtesy of United States Naval Institute 
German, Niehoff was later transferred back to Camp Lejeune, North Carolina, where he became an instructor for Dutch Marines. On 7 October 1945, he was discharged there, and hitchhiked back to Portland. Later rejoining the Portland Marine Reserve, he was activated again in 1950 for the Korean War, but was medically discharged based upon complications from a World War II field surgical operation.

Another Portland Reserve Marine who was not so fortunate, was Captain Lloyd Wagner, the former commander of Company A, 20th Battalion. Upon their April 1941 arrival in San Diego, he was transferred first to 6th Marine Regiment and later to Battery C, 3rd Battalion, 4th Marine Regiment in China. Captured by the Japanese on Bataan, in the Philippines, on 9 April 1942, he was later killed when his prison ship was torpedoed inadvertently by an American submarine. Ironically, his Marine Mameluke sword was recovered in 1945. It was taken from a Japanese prisoner by Captain Knapp, who had served as an enlisted man before the war in Company F, 11th Battalion.

The Japanese attack on Pearl Harbor was also witnessed firsthand by Second Lieutenant Carl Viggo "Swede" Larsen of Lebanon, Oregon, who was on watch aboard the cruiser USS Honolulu. A Japanese dive bomber hit the ship near his position at skyforward (the light anti-aircraft battery), but fortunately the bomb passed through the hull and imbedded in the pier before exploding. A graduate of Oregon State University with a degree in mechanical engineering, Larsen was later recommended in the Solomon Islands for the Navy Cross in attempting to salvage an unexploded Japanese "Long Lance" torpedo from the ship's stern. He had joined the Marine Corps in June of 1940, 
and had been aboard the USS Honolulu since June of 1941 as the executive officer of the 47 man Marine detachment. After serving throughout the Pacific, he attended Chinese language school and served in Tsingtao, China, as the intelligence officer for 6th Marine Division until March 1946. He later brought his command (1st Battalion, 1st Marine Regiment, 1st Marine Division) back to the United States in the summer of 1955 as the last Marine battalion out of Korea. Colonel Larsen retired from the Marine Corps in $1962 .{ }^{94}$

Another Pacific Northwest native to experience the Japanese attack on Pearl Harbor was Claude Arthur Larkin, of New Era, Oregon. ${ }^{95}$ As the commanding officer of Marine Air Group-21, at Ewa, Oahu, Lieutenant Colonel "Sheriff" Larkin was the highest ranking Marine flyer west of San Diego. Having enlisted in the Marine Corps in December 1915, he was commissioned in July 1917 . Following service in Cuba, he was designated a naval aviator in 1940, and served in Haiti, China, and the Virgin Islands. Prior to World War II, Larkin served as assistant naval attache for air in London and Cairo, where he closely observed Royal Air Force operations. During the Pearl Harbor attack, all but one of MAG-21's 48 aircraft were destroyed. Continuing to serve throughout the Pacific War (where he commanded both the 1st and 3rd Marine Aircraft

\footnotetext{
${ }^{94}$ Personal Interview between C. V. Larsen and author, Lebanon, Oregon, 13 January 1994.

${ }^{95}$ Marion E. Carl, Pushing the Envelope, selection from Marine Corps Gazette (Quantico, February 1994), p. 77.
} 
Wings), Major General Larkin retired from the Marine Corps in 1946 with both a Bronze Star and two Legions of Merit.

Corporal Elmer Sidney Drake Jr, of Portland, had joined Company F, 11th Battalion in November of 1939, and then later transferred to active duty in January 1940. He soon found himseif assigned to the 1 st Defense Battalion on Wake Island $(2,300$ miles west of Pearl Harbor) with a fellow Portlander, Private First Class William Frank Bostick. Drake was noted as a quiet, level headed 5' Battery B crewman, while the outspoken Bostick manned a water cooled .50 calibre machine gun. Both fondly recalled their Wake Island commander, Major James P. S. Devereux initially addressing them as a First Lieutenant in the spring of 1940 by stating: "I'm going to make Marines of you if it kills every damned horse in my stable." ${ }^{96}$ Drake, a graduate of Roosevelt High School in St. John, was later cited by his battery commander for his steady work at his gun in scoring repeated hits against Japanese warships. Bostick had joined the Marine Corps right out of Hood River High School. In June 1939, he hitchhiked to Portland on a Pacific Produce truck, walked up to the 4th floor of the old Federal Building (just off of what is today Pioneer Square) and enlisted. As Bostick was only 17 years old, he required a signed release from his mother. He celebrated his 20 th birthday on Wake Island on 2 November 1941. Bostwick was also later cited for bravery in manning his position against repeated Japanese attacks. These close friends spent the next four years

\footnotetext{
${ }^{96}$ Personal Interview between W. F. Bostick, E. S. Drake, and author, Portland, Oregon, 28 February and 4 April 1994.
} 

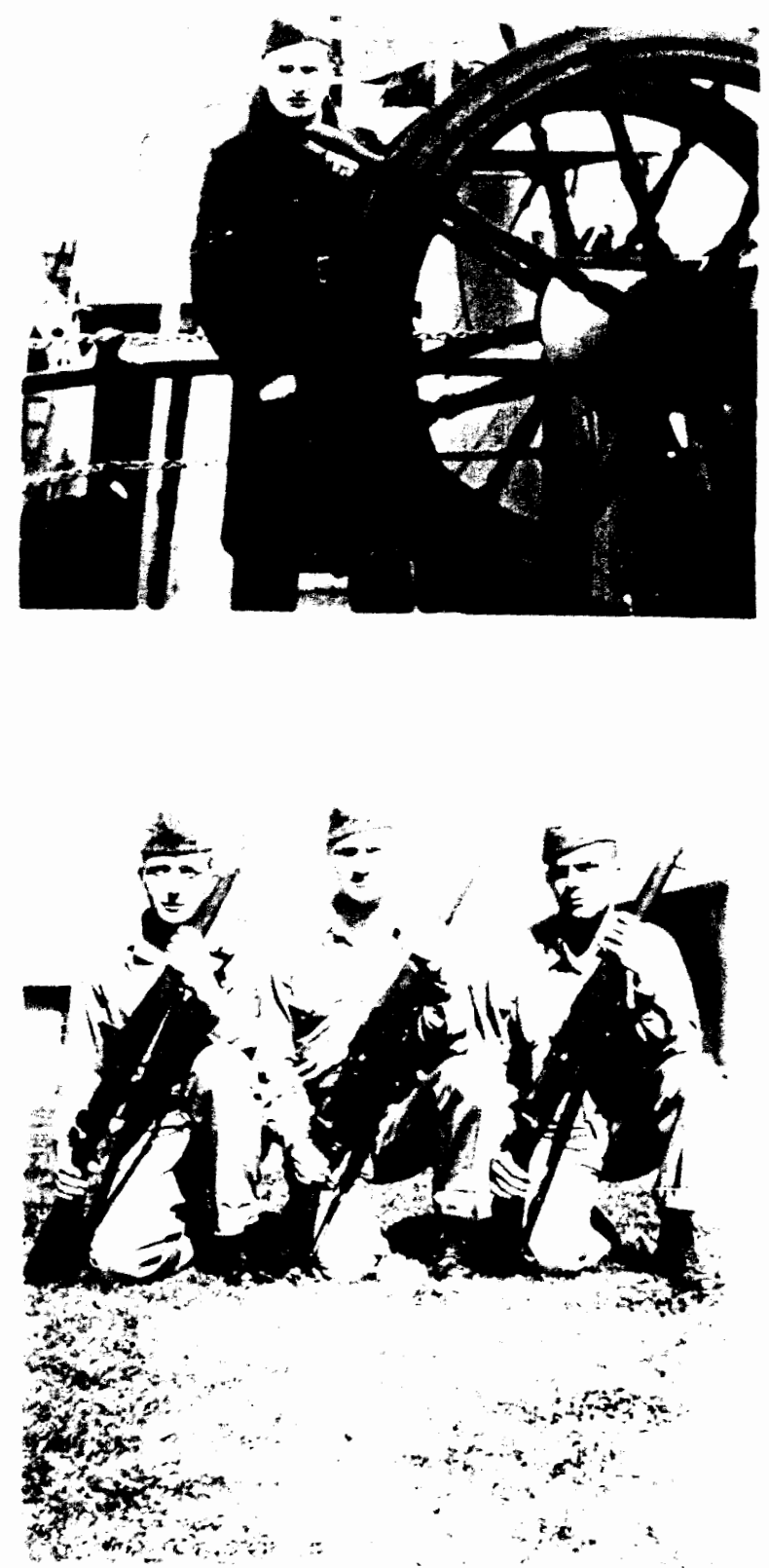

Figure 27: Elmer S. Drake Jr., of Company F, 11 th Battalion, aboard the USS Oregon in Portland, 1939

Figure 28: Elmer S. Drake Jr. (center) and two Marine buddies with their 1903 Springfield rifles, just prior to his deployment to Wake Island, 1941.

Photos courtesy of Elmer $S$ Drake Ir Collection 
in various Japanese prisoner of war camps ranging from Woosung, China, to Nowitsu, in Hokkaido, Japan. They were eventually liberated on 5 September 1945, evacuated by train via Yokohama, and brought to San Francisco on U.S. Navy shipping via Guam. Bostick stated that he went from 130 to 190 pounds in 30 days. A total of 11 Marines from Oregon served in the 16-day epic defense of Wake, which lasted from 8 to 23 December 1941. The 477 Marine defenders were the only force to successfully repel an amphibious landing in World War II, when on 11 December 1941, they outgunned the larger Japanese 4th Fleet, sinking two destroyers, and damaging three cruisers, three other destroyers, and two troop transports. Four Marine fighters shot down a total of 21 Japanese aircraft. The invasion was postponed for another twelve days until 23 December 1941, when the Wake defenders were overwhelmed by a carrier task force and 2,000 Japanese Special Naval Landing Force personnel. Wake's tenacious defense blunted Japanese momentum and raised American home front morale in what President Roosevelt called: "This great fight." A Japanese commander who participated in the initial invasion attempt stated that Wake was "one of the most humiliating defeats our Navy ever suffered." ${ }^{97}$ All eleven of the Oregon Marines from Wake Island were fortunate enough to survive both the battle and the harsh imprisonment. ${ }^{98}$ Drake attributed this to the Oregonians all being so "mean and ugly." He was discharged as a

\footnotetext{
${ }^{97}$ Veterans of Foreign Wars (VFW) 50th Anniversary of WWII Magazine, December 1991, p. 18.

${ }^{98}$ James P. S. Devereux, The Story of Wake Island, (New York, 1947), p. 245246.
} 

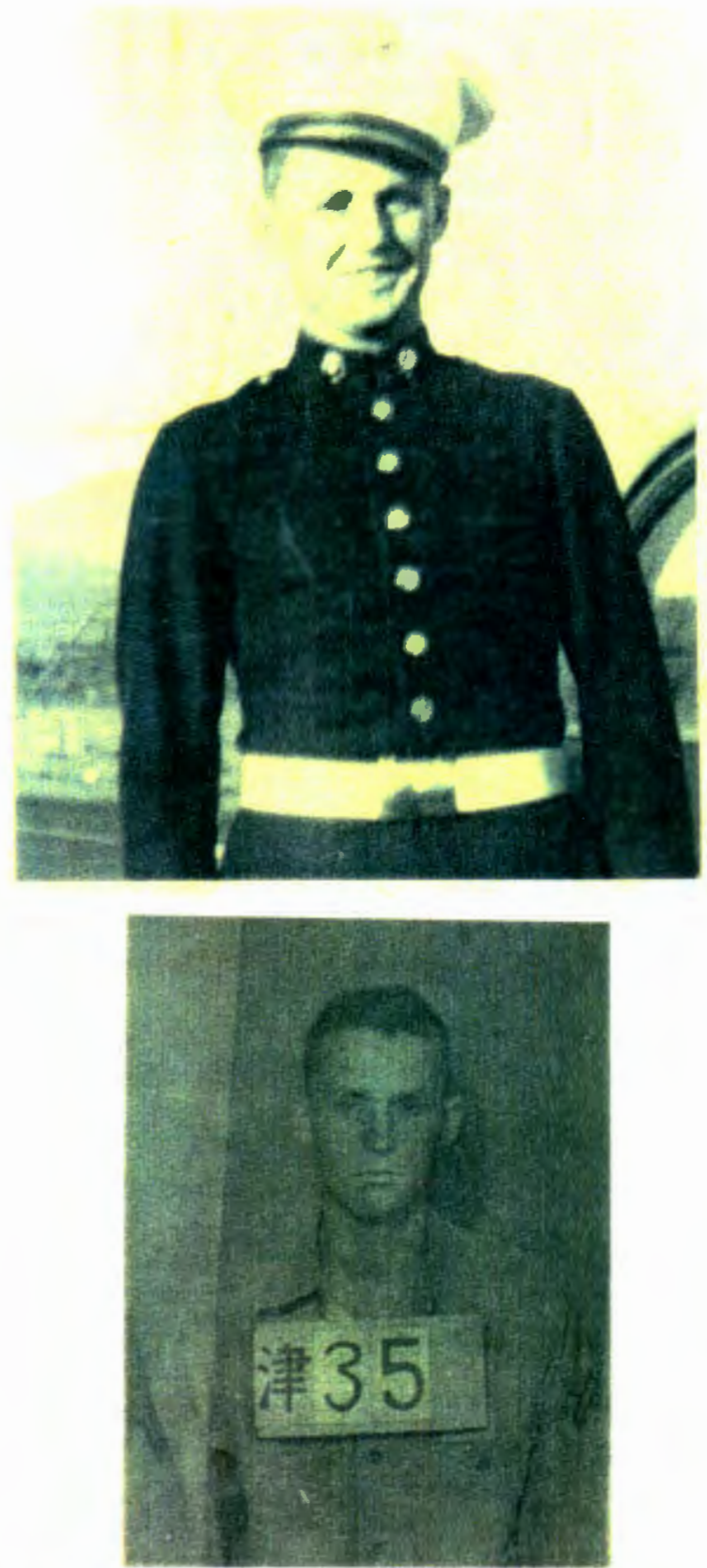

Figure 29: William F. Bostick, of Portland, immediately prior to his deployment to Wake Island.

Figure 30: Japanese Prisoner Of War identification card photo of William F. Bostick taken following the fall of Wake Island in December 1941.

Photos courtesy of William E Bostick Collection 
sergeant on 6 April 1946, while Bostick retired on 19 September 1951 as a staff sergeant. Together, they later formed a "Barbed Wire Club" in Portland after the war.

For six months, the Japanese offensive in the Pacific proceeded almost unchecked. American and Allied forces were overwhelmed and driven back. The last major resistance on Corregidor in the Philippines ended on 6-7 May 1942. Here, the exhausted 4th Marine Regiment, originally stationed in China, burned its colors and surrendered alongside its US Army comrades. One of those "China Marine" veterans was Private First Class Robert Dale Henderson, of Portland, Oregon. He joined the Marine Corps in November of 1940, and volunteered for duty in China. Arriving in Tsingtao, China, aboard the USS Chaumont, on a freezing day in early 1941, he was assigned to Company A, 1st Battalion, 4th Marines. His battalion commander, Lieutenant Colonel Curtis Beecher, was fondly remembered as a real professional. Beecher was also an Oregonian, from Roseburg. Henderson enjoyed China duty, but came down with typhoid fever in October 1941 and was sent to Cavite Naval Yard, Philippines, aboard the USS Archibald Henderson. Upon the outbreak of war, he served on Corregidor as a guard for the communications center and later as a company runner. His company commander, Captain Lang, was killed on Corregidor shortly before the surrender. Henderson recalls their primary diet during the siege consisting of biscuits and canned tomatoes, which was much better than the rice, sweet potato sprouts and occasional fish that Japanese prisoner of war camps offered over the next three years. Weighing 148 pounds when he joined the Marine Corps, Henderson weighed 108 pounds 
upon liberation. During their imprisonment, the Americans, New Zealanders, and Koreans were forced to work in coal mines near the Omuta Mitsubishi zero factory on Kyushu, Japan. The B-29 and carrier plane raids later in the war were a tremendous motivator, as were the $\mathrm{C}-47$ fruit cocktail drops following the surrender of Japan. Corporal Henderson was discharged from the Marine Corps in the summer of 1946.

Meanwhile, just as American forces were forced to surrender on Corregidor, the United States Navy blunted a Japanese southward drive toward Australia at the Battle of the Coral Sea on 7-8 May 1942. A significantly more powerful Japanese eastward drive toward Hawaii was crushed on 4 June 1942, at the Battle of Midway. By virtually destroying Japan's offensive carrier air capability, the United States Navy had provided a rapidly mobilizing America with a magnificent opportunity to turn the tide in the Pacific. No one better understood this than Admiral Ernest Joseph King, Chief of Naval Operations and Commander in Chief of the United States Fleet. As naval advisor to President Roosevelt, and with the approval of the Joint Chiefs of Staff, an American offensive campaign was set for August 1942. To accomplish this task, the tools, and the only tools, were the victorious carriers of the United States Navy and the men of the 1st Marine Division. To quote "the" historian of the Marine Corps, the later Colonel Robert Debs Heinl Jr.,: "The long road back had commenced." 99

Code named Operation Watchtower, the first American offensive of World War II commenced on 7 August 1942, on Guadalcanal, in the Solomon Islands. Now under

${ }^{99}$ Heinl, Soldiers of the Sea, p. 347 
the command of Major General Alexander Archer Vandegrift, the 19,000 men of the 1st Marine Division secured a jungle beachhead in what was to become one of the toughest campaigns of the war. For the next five months, an arduous battle of attrition focused on Guadalcanal. United States naval support and supplies were briefly withdrawn because of strong Japanese naval activity. The US Navy controlled the waters around Guadalcanal by day, while the Japanese Navy controlled this same area at night.

Among those Marines from Oregon at Guadalcanal was Marion Eugene Carl. Born in Hubbard, Oregon, on 1 November 1915, Carl (like "Swede" Larsen) had a degree from Oregon State University in mechanical engineering. Commissioned a Second Lieutenant on 1 December 1939, and having received his Naval Aviators Wings, Marion Carl was destined to become a Marine legend. Aside from seeing his first combat flying at the Battle of Midway, his career was firmly established at Guadalcanal, where he became the first Marine Corps ace with five Japanese aircraft shot down on 26 August 1942. It was also during this period that he was forced to bail out of an F4F Wildcat at $20,000 \mathrm{ft}$. He would eventually have $18 \frac{1}{2}$ destroyed enemy aircraft to his credit, having seen combat duty through World War II, Korea, photo-reconnaissance flights over China, and Vietnam. When he retired from the Marine Corps on 1 June 1973, Major General Carl had earned 2 Navy Crosses, 5 Distinguished Flying Crosses, 4 Legions of Merit, and 14 Air Medals, among other awards. As to his other accomplishments, Carl accumulated over 14,000 flight hours, was the first Marine designated as a helicopter pilot (July 1946), the first Marine to land a jet on an aircraft carrier (1 November 1946), 


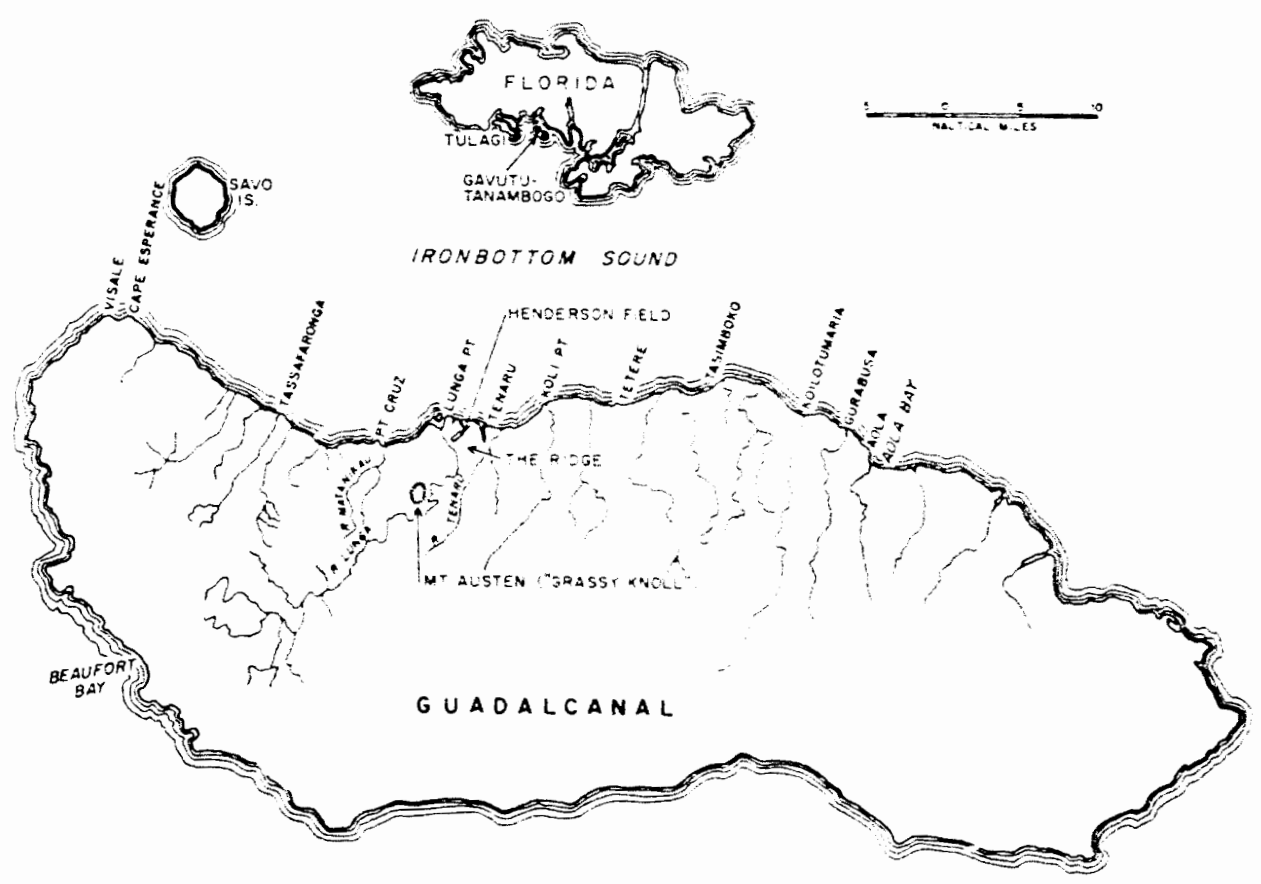

Battle of Guadalcanal, 10 August 1942 to 8 February 1943.

Figure 31: Map of Guadalcanal Island, the Solomon Islands, 1942.

Soldiers of the Sea by Heinl, p. 351 
the first pilot in the world to be catapulted in a jet from an aircraft carrier (P-80 Shooting Star, 1 November 1946), set a world speed record (650.7 mph in a Douglas Skystreak, 25 August 1947), set a world altitude record $(83,235 \mathrm{ft}$ in a Douglas Skyrocket, 21 August 1953), commanded two different fighter squadrons (including the first jet squadron), an aircraft group, an aircraft wing, and a Marine brigade. He flew 260 different types of aircraft (to include 30 various experimental and captured enemy aircraft). In addition to the incident of bailing out of his aircraft over Guadalcanal, Carl was also forced to bail out of a test aircraft over Chesapeake Bay and survived two crash landings. He fractured his back in this last incident. In 1973, Major General Carl retired to his family farm in Roseburg, Oregon, where in 1994, he completed his autobiography. ${ }^{100}$

Still another noted Marine aviator who made a name for himself during the Solomon Island campaign, was John Daniel Harshberger of Leaburg, Oregon. Graduating from California Technical Institute, Pasadena, California, with a degree in electrical engineering, Harshberger joined the Marine Corps in 1936, was commissioned, and earned his wings at Pensacola, Florida.

Later described by General Marion Carl as "the best instrument pilot the United States ever had," Harshberger was "bitten early by the night-fighter bug." 101 By late

${ }^{100}$ Marion E. Carl, Pushing the Envelope, (Annapolis, 1994), selected.

${ }^{101}$ Robert Sherrod, History of Marine Corps Aviation in World War II, (San Rafael, 1952), p. 160. 

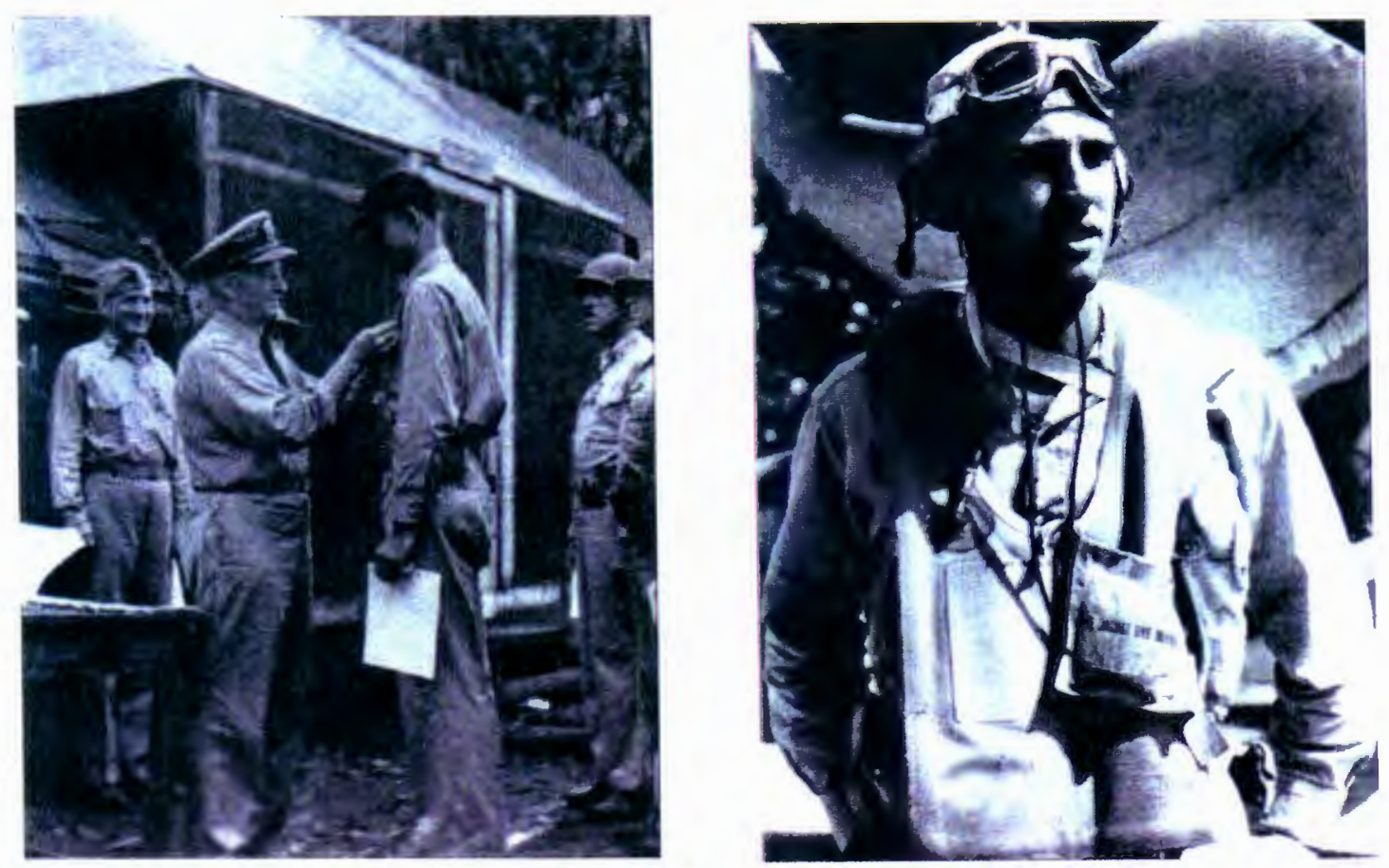

Figure 32: Marion E. Carl, of Hubbard, being awarded Navy Cross by Admiral Nimitz, Guadalcanal, 1 October 1942.

Figure 33: Marion E. Carl circa 1943.

Photos courtesy of Marine Corps Gazette 
1942, Japanese aviation tactics had switched from day to night bombardment, which Admiral Halsey referred to as a sleep-killing "nuisance." Based on British tactics, the first Marine night-fighter squadron, $\operatorname{VMF}(\mathrm{N})-531$ was formed on 16 November 1942 at MCAS Cherry Point, North Carolina. With Major Harshberger serving as executive officer, and later as commanding officer, the squadron was outfitted with fifteen twinengined, three man crew Vega Ventura PV-1's, which were equipped with an additional six . 50 caliber guns in the nose, a Mark IV radar, and other new electronic equipment. VMF(N)-531's, 26 pilots and 322 enlisted men, despite a shortage of proper aircraft, parts, personnel and training, were operating in combat over the Solomon Islands from Vella Lavella Island by 18 October 1943, largely due to "Iron John" Harshberger's leadership, determination, and innovation. Harshberger shot down the squadron's first enemy aircraft on 6 December 1943 over Bougainville. When the squadron was relieved in June 1944, Harshberger had a total of four Japanese kills to his credit, two of which he got on the same night, for which he was awarded the Distinguished Flying Cross. A pioneer in Marine night-fighter intercept doctrine, Brigadier General Harshberger retired from the Marine Corps to his Oregon home in 1959.

There is a saying in the Marine Corps that every Marine is a rifleman, and whether a combat engineer, artilleryman, tanker, administrator, logistician, or pilot, all Marines would readily acknowledge that without the primary "0311 Infantryman," every other Marine military occupation speciality is unemployed. Despite all the Marine aviation accomplishments which are so well represented by Major General Carl, he 

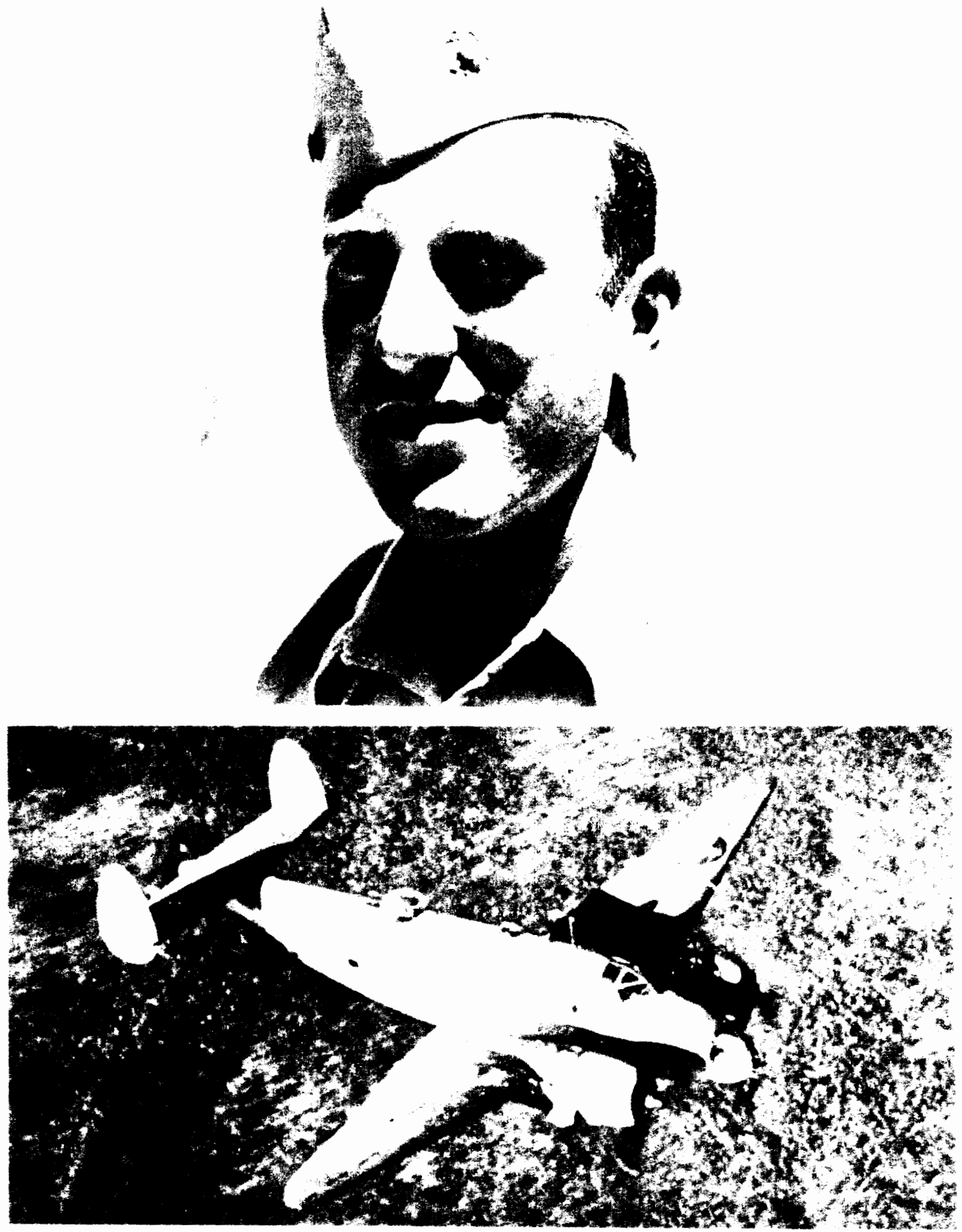

Figure 34 John D Harshberger, of Leaburg, Oregon, circa 1942-1943.

Figure 35: A Marine PV-1 Ventura night fighter of Harshberger's VMF(N)-531 over Guadalcanal.

Photos courtesy of John D and Mary "Lisey" Harshberger Collection 
repeatedly emphasized that the vast majority of contributions to the war effort on islands such as Guadaicanal were by infantrymen on the front line.

Such is the story of Marine infantryman Corporal Gordon William Morgan, of Portland. Born in Alberta, Canada, he joined the Marine Corps on 8 December 1941. Following boot camp in February of 1942 , Morgan was initially assigned to Company D, 1st Battalion, 1st Marine Regiment, but was later reassigned to Company G, 2nd Battalion, 7th Marine Regiment of the 1st Marine Division. Deployed first in May 1942, to garrison Savai'i in British Samoa, he landed at Guadalcanal from the USS Hayes on the overcast morning of 18 September 1942. On 25-26 October 1942, Japanese General Masao Maruyama committed his crack Sendai Division, backed by a regiment of $150 \mathrm{~mm}$ howitzers and tank support, to the sole objective of overrunning 1st Marine Division and taking Henderson Airfield. To do this, he launched 5,600 men (8 Japanese battalions) against Vandegrift's southern perimeter while also sending another 2,900 men backed by the Japanese armor against the western Marine positions on the Matanikau River. Desperate fighting ensued in which Marines managed to beat off repeated Japanese attacks. On Hanneken's Ridge (named after Lieutenant Colonel Herman H. Hanneken, commanding officer of 2nd Battalion, 7th Marines), to the west of Henderson overlooking the Matanikau, the better part of a Japanese regiment hit Company F, 2nd Battalion, 7th Marines. The Japanese assault actually overran the Marine position, but the battalion executive officer, Major Odell M. Conoley, rallied cooks, messman, communicators, and runners and retook the ridge in a desperate counterattack. 
Vandegrift's Marines had held against the enemy's strongest attack. Before the thin Marine lines, were strewn over 3,500 Japanese dead, including at least one general and two regimental commanders. Two Marines earned Medals of Honor during this engagement: Sergeant John "Manila John" Basilone of Company D, 1/7 (whose machine gun section had expended 26,000 rounds before daybreak on the 26 th) would later be killed on Iwo Jima in February 1945 with 5th Marine Division. Sergeant Mitchell Paige of Company $\mathrm{H}, 2 / 7$ earned both the award and a battlefield commission for also leading his machine gun section against overwhelming odds in the predawn hours of the 26th. Paige would later be stationed at Marine Barracks Klamath Falls, Oregon, for treatment of recurring malaria in 1944. At dawn on 26 October 1942, Gordon Morgan was moving forward with his squad from Company F, 2/7 to reinforce Paige's right flank on Hanneken's Ridge. Suddenly, a Japanese soldier to their direct front sprang up and opened fire with a light Nambu machine gun. Morgan took five 7.65 calibre rounds in both thighs, his buttocks, and his left hand while the enemy infantryman was killed in a hail of return Marine fire. The following day, he was evacuated by air to the New Hebrides and later to New Zealand. By January 1943, Morgan returned to limited duty and was assigned to Naval Air Station Alameda, California. In February 1945, he was transferred to Marine Barracks, Naval Air Station, Astoria, Oregon, where his primary duty was providing armed security for the ammunition bunkers, and assembly and repair shops at Tongue Point (three miles due east of Astoria). Following his discharge from the Marine Corps, on 20 August 1945, Gordon Morgan spent the next thirty years with 


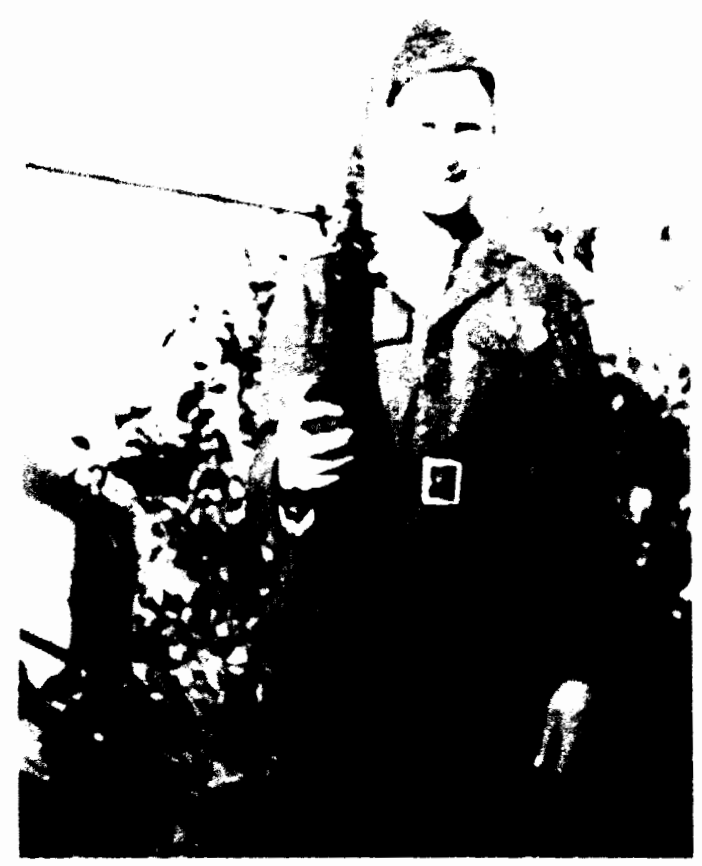

Figure 36: Gordon W. Morgan, of Portland, immediately prior to deployment with Company G, 2nd Battalion, 7th Marines, 1st Marine Division to Guadalcanal, 1942. He was severely wounded on "Hannikan's Ridge" at the height of the Guadalcanal campaign and was eventually transferred to Marine Barracks Astoria, Naval Air Station Tongue Point, Oregon. Morgan later retired after thirty years with the Portland Police Bureau and founded the Oregon - Columbia River Chapter of the 1st Marine Division.

Photo courtesy of Gordon W Morgan Collection 
the Portland Police Bureau, where he retired as a Sergeant on 3 September 1975. In 1984, Morgan was able to track down and call the Florida home of his former machine gun section head on Guadalcanal, "Private First Class" Winiford "Winkie" Mason Owens. Explaining to Owens' wife who he was, she relayed this information to her husband who was watching a football game on TV. Over the phone in the background, Morgan heard the response of: "Can't be him ... he's dead." Morgan was soon able to assure "Winkie" that he had indeed survived Guadalcanal. Gordon Morgan was also later instrumental in founding the Oregon/Columbia River Chapter of the 1st Marine Division Association. ${ }^{102}$

Another interesting aspect of the war in the Pacific is that of the development of heavy engineer equipment and tank support for the Marine infantryman. On 1 Dec 1942, Private Emil "Ernie" E. Huxel, of The Dalles, enlisted in the Marine Corps and because of his civilian bulldozer experience, was assigned following boot camp to the new Marine Tank School at Jacques Farm, Camp Elliott., near San Diego. Huxel then joined the 1st Tank Battalion, which had just received its new medium M-4 Sherman tanks at Oceanside, California. Here, during the spring and summer of 1943 , he became an extra in the Hollywood production of the film Guadalcanal Diary, filmed at Aliso Canyon, Camp Pendleton. Receiving $\$ 10.00$ a day as an extra (which had to be donated to the Red Cross), Huxel enjoyed the opportunity of eating meals with actors William Bendix

${ }^{102}$ Personal Interview between Gordon Morgan and author, Portland, Oregon, 29 November 1993. 

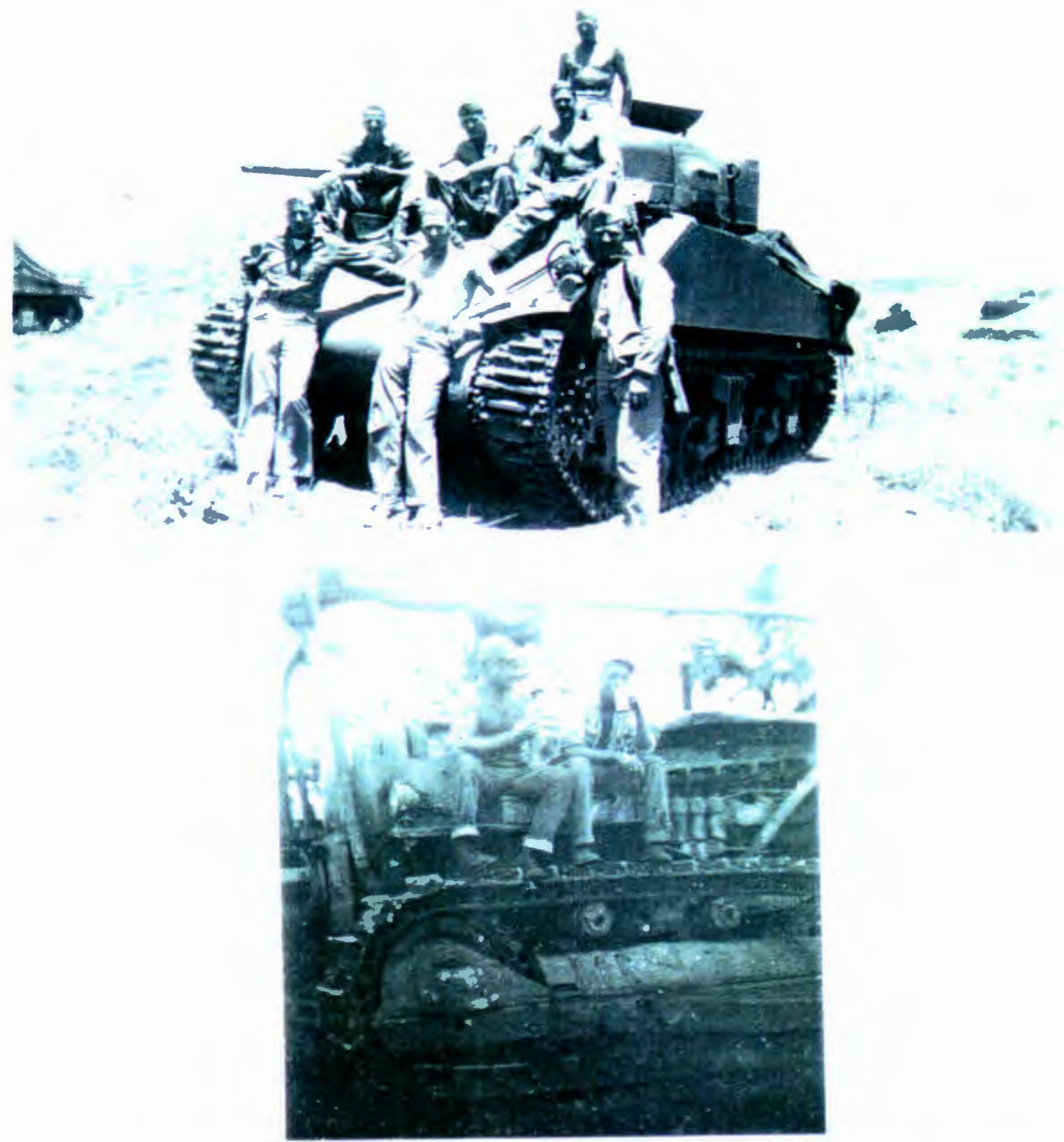

Figure 37: Emil E. Huxel, of The Dalles, with first new Marine medium M-4 Sherman tanks north of Oceanside, California, 15 June 1943.

Figure 38: Emil E. Huxel taking a break while operating a bulldozer during the retaking of Guam, July 1944.

Photos courtesy of Emil E. Huxel Collection 
and Anthony Quinn. Later deployed to the Pacific, he saw serious action at Peleliu with the 1st Marine Division.. On 15 September 1944, while serving as a mortarman with Company M, 3rd Battalion, 1st Marine Regiment, he earned a Purple Heart on White Beach when wounded in the left leg by Japanese mortar shrapnel. Corporal Huxel ended the war with 1st Marine Division on garrison duty in Tientsin, China. He was discharged in San Diego in January 1946 and, as of this writing, continues to work as a bulldozer and heavy equipment operator out of The Dalles. ${ }^{103}$

While Marines were focused on their primary mission of "closing with and destroying the enemy" in the central Pacific, interesting events involving Marines were transpiring back in Oregon. Aside from the traditional Marine Corps recruiting stations and substations in major Oregon Cities such as Portland, Salem, and Eugene, three new Oregon geographical sites became bases for Marines. These were: the Marine Barracks, Naval Air Station Astoria, at Tongue Point (where veterans such as Gordon Morgan were stationed), the Marine Barracks, Naval Air Station Tillamook, and lastly, the unique Marine Barracks Klamath Falls, which was essentially a malaria recovery base for returning Pacific veterans.

The history of Marine Barracks Astoria dates back to 30 August 1939, when the United States Navy began construction of its Naval Air Station at Tongue Point. Originally charted by American Captain Robert Gray from the Columbia Rediviva in May

${ }^{103}$ Personal Interview between Emil Huxel and author, Portland, Oregon, 7 August 1994. 
of 1792, Tongue Point received its descriptive name from British Lieutenant William Broughton of HMS Chatham in October of 1792. In November 1805, Lewis and Clark had spent several days camped here. On 29 August 1940, the first 21 Marines of what would eventually become a company size detachment of approximately 120 Marines reported in from Marine Barracks, Bremerton Navy Yard, in Washington. This original group was under Platoon Sergeant Samuel A. Johnstone, Jr., with the first commanding officer arriving in early 1941, an old World War I thirty year veteran named Captain Bernard "Barney" Watchman. ${ }^{104}$ Marine duty was to provide security for both the facility at Tongue Point and for the Naval Air Facility, Astoria, located at the Clatsop County Airport southwest of Astoria. The base consisted of a number of ammunition bunkers and nearly eight dozen small high-explosive magazines built into the hillsides on the northern tip of the point. The main base complex was on the east side, where most business focused on the two large hangars, 1,350,000 square feet of aprons (enough to accommodate 48 PBY amphibious patrol bombers), storage for 700,000 gallons of aviation gasoline, the pier, and the assembly and repair shops. The main role played by the base in World War II was as the pre-commissioning and commissioning site for escort aircraft carriers. Better known as "jeep" or "baby" "flattops," these were built by the Kaiser Shipyards in the Portland-Vancouver area. Tongue Point averaged a military

${ }^{104}$ Personal Interview between Master Sergeant Wayne Warren Huskey USMC (Ret) and author, Stayton, Oregon, 3 April 1994. 

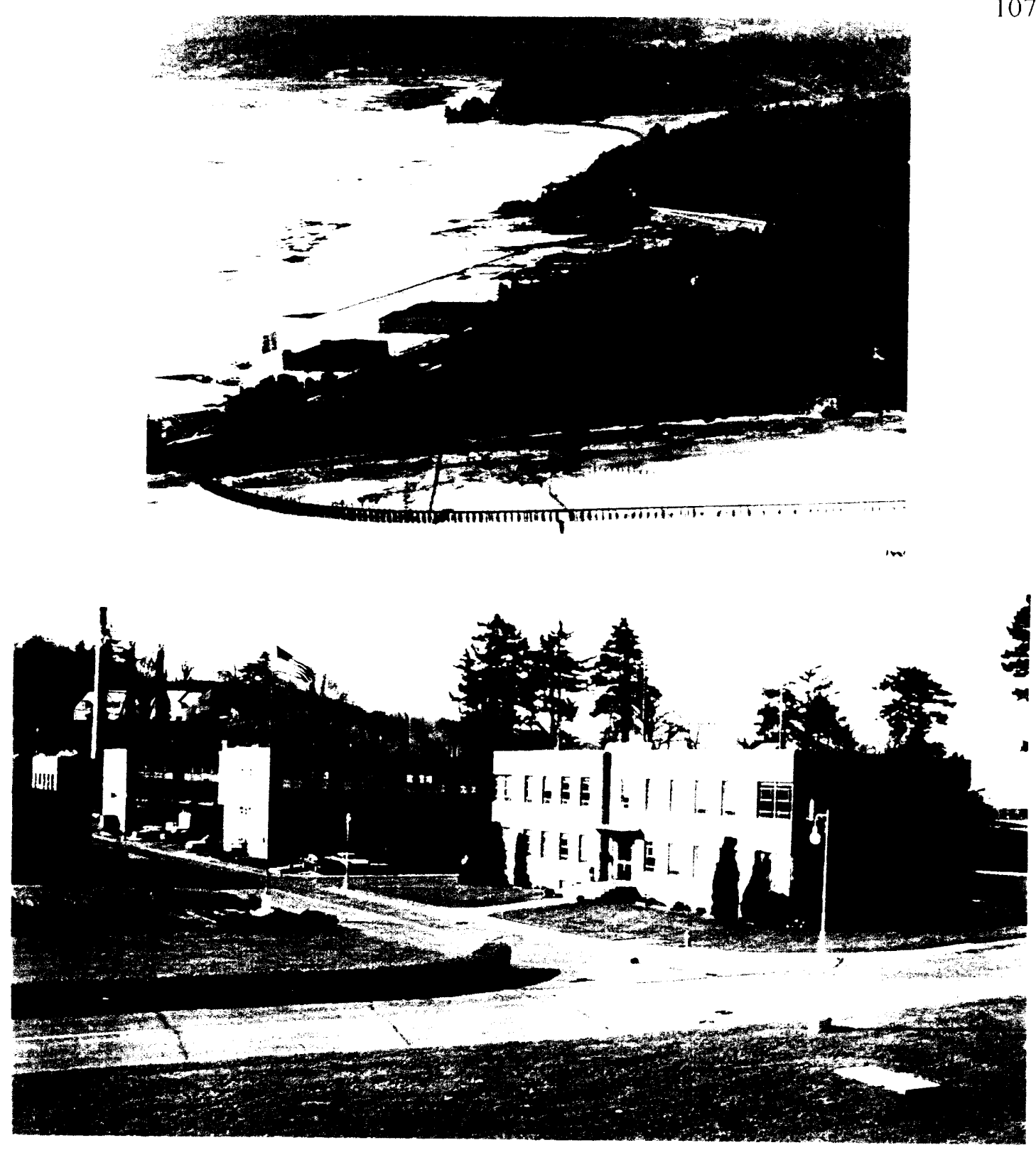

Figure 39: Naval Air Station Tongue Point, Astoria. View is looking southeast from Columbia River. Note huge aircraft hangars and two Navy amphibious patrol aircraft near northern ramp.

Figure 40: Marine Barracks, Naval Air Station Tongue Point. Headquarters building is on right while actual Marine barracks facility is left of center.

Photos courtesy of Clatsop County Historical Society 
population of 3,000 during this period ${ }^{105}$ and in all, it is estimated that approximately 20,000 Navy, Army, and Marine personnel served in the Astoria area during World War II. ${ }^{106}$ Marines had their own barracks next to the headquarters building, and their main duties focused on security. Guard posts were established at the main gate, the bunker complex, the brig (in the basement of the barracks), to include perimeter patrols, and a daily detail sent out to provide security at the Astoria airport. Despite Tongue Point possibly being considered a backwater to the war in the Pacific, it was not ignored by organizations such as the USO (United Services Organizations) and Hollywood celebrities such as actress Shirley Temple, who visited the area in the spring of 1945 (Corporal Gordon Morgan of Portland, remembers following her in the chow line at the Astoria Naval Hospital). By April 1945, the official Muster Roll for Marines at Tongue Point listed one Captain, and 127 enlisted Marines on station. Marines continued their diverse security duties here until shortly after the war, when the Marine Barracks, under the command of Captain Robert A. McCabe, is believed to have been shut down in May of 1946. The Navy departed Tongue Point in 1962.

The Marine Barracks Tillamook, at the Naval Air Station Tillamook, was established on 2 March 1943, when Captain John W. Sherman reported in from the Marine Barracks, Bremerton Navy Yard, with a platoon size detachment of 32 Marines,

${ }^{105}$ Lucille Perkins, Old Salts, 1983 Tongue Point Reunion Publication, Warren, Oregon, p. 2.

${ }^{106}$ Columbia River Maritime Museum, The Quarterdeck, Vol. 19, \#2, Winter 1993, p. 5. 

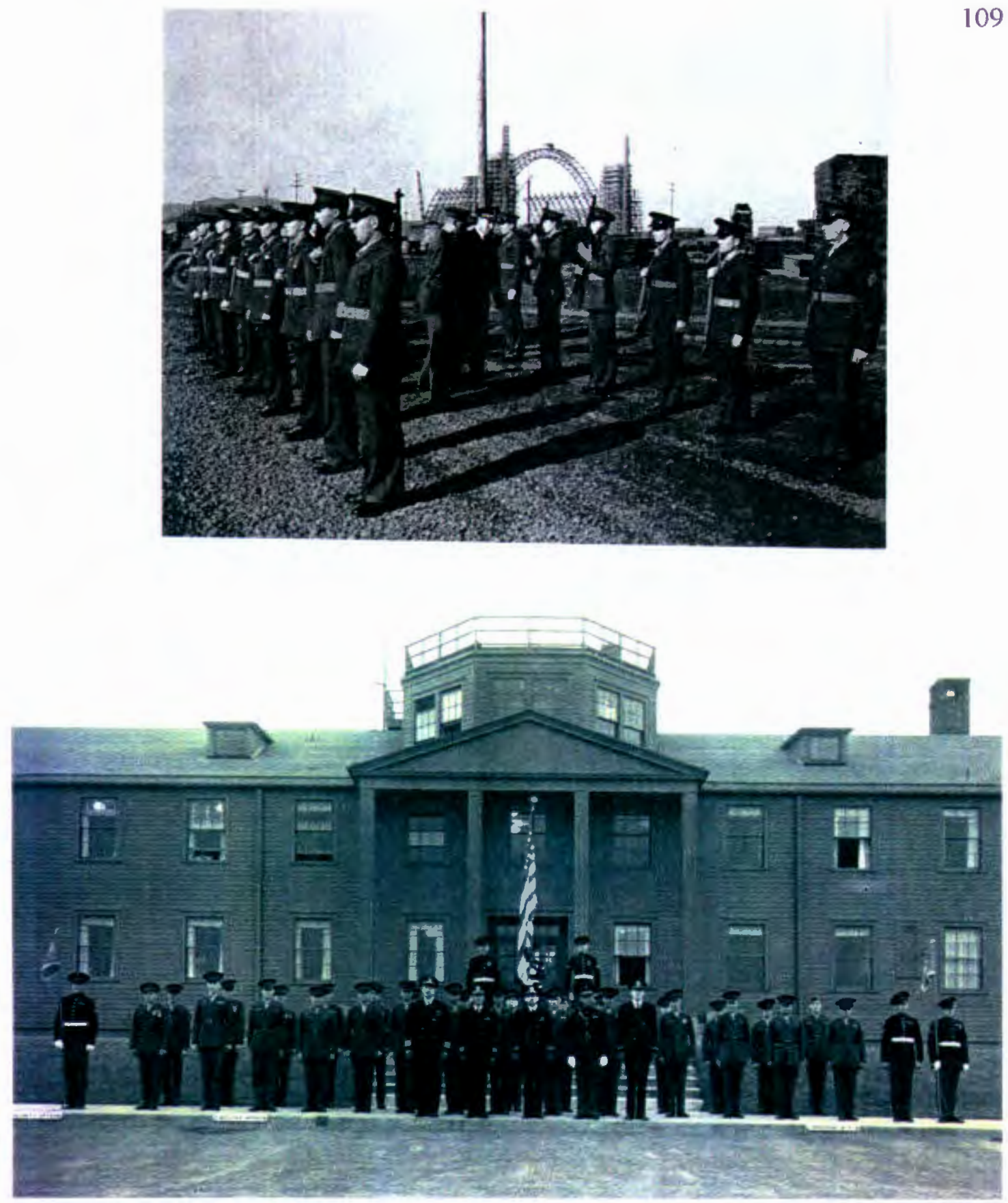

Figure 41: Marines arrive at Naval Air Station Tillamook in March 1943, while Lighter Than Air (LTA) Squadron ZP-33 hangars are still under construction.

Figure 42: 10 November 1943 Marine Corps birthday formation in front of Headquarters with senior Navy staff of Naval Air Station Tillamook.

Photos courtesy John W. Sherman Collection 
which moved into "Barracks One." The purpose of the Marine detachment was stated as being twofold: primary was to enforce security measures on the station; secondarily, these combat veterans returning from the Pacific were to take a well-earned rest. Typical of those Marines assigned here were Platoon Sergeant W. W. Easterling and Corporal J. D. Hartley, who had won Bronze and Silver Stars respectively at the Battles of Iwo Jima and Okinawa. Though far from the front lines, the Tillamook Marines were far from forgotten, as was proved by a visit on 11 July 1945 by Major General Julian J. Smith (Commanding General of the Department of the Pacific). Like the Astoria/Tongue Point Marines, a high percentage of Tillamook Marines had earned Purple Hearts in the Pacific. As stated, their role now was to provide security for ZP-33, the Navy LTA "lighter than air" squadron of eight blimps. These "K" type blimps were approximately 250 feet in length, capable of remaining aloft 48 hours at speeds up to 50 knots per hour. Built at a cost of $\$ 7,000,000.00$, the base occupied 1,500 acres south of Tillamook. The mission of this squadron was to provide convoy escort and patrol against Japanese submarines along the Pacific northwest coast from Alaska to the California border. The two blimp hangars at Tillamook were (and the one surviving still is) the largest all wood clear span buildings in the world: 1,000 feet long, 296 feet wide, and 195 feet tall. Alone, each covered over seven acres of floor space, with enough area to handle six football games at the same time. Started in October 1942, both hangars were completed in August 1943. The first blimp (K-31) landed on 15 February 1943, with operations continuing until 24 October 1945, when the last blimp (K-97) departed. On 10 

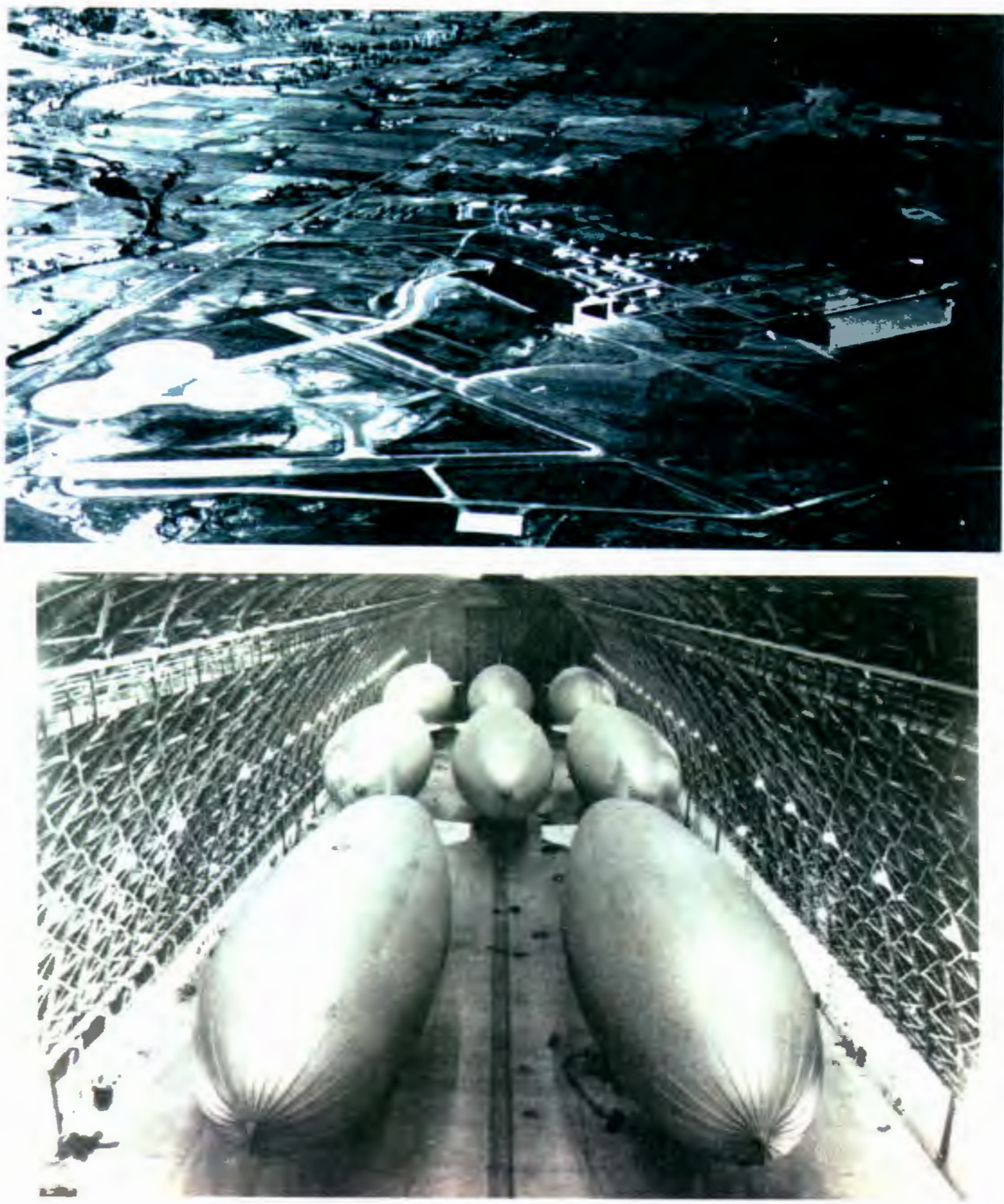

Figure 43: Naval Air Station Tillamook, 1944.

Figure 44: Blimps of Lighter Than Air Squadron ZP-33 in hangar, which is the largest all wood clear span structure in the world (1,000' long, 296' wide, 195' high; equal to area of six football fields), 1944.

Photos courtesy of Tillamook County Pioneer Museum 
November 1945, Squadron ZP-33 was decommissioned. The Marine Barracks, under the command of Captain Earl P. Norberg, was deactivitated on 31 January 1946. The final entry concerning Marines at Tillamook was this: "The leaving of the Marines may be taken as a sign that the time is growing near when we will all be leaving; going home we hope. At any rate we wish them a happy future."107 Naval Air Station Tillamook was finally vacated by the Navy in 1948 .

Another brief but interesting aspect of Marine Corps history in Oregon is that of the story of Marine Air Group-35. With the rapid buildup of Marine aviation units during World War II, MAG-35 was formed on 1 April 1943 at Cherry Point, North Carolina, and consisted of Headquarters Squadron-35, Service Squadron-35, VMJ-352 (Photo Recon), and VMO-351 (Observation). It departed 20 April 1944 for Miramar, California, but its destination was changed en route and MAG-35 arrived 27 April 1944 at Army Air Facility (AAF) Corvallis, Oregon, which was redesignated Marine Corps Air Facility (MCAF) on 5 May 1944. ${ }^{108}$ The mission of MAG-35 was to organize and train Marine aviation personnel in all phases of transport aircraft, and furnished replacement aircraft and crews for overseas duty. The unit consisted of approximately 1,600

\footnotetext{
${ }^{107}$ NAST (Naval Air Station Tillamook) Newsletter, Volume III, \#7, 1 February 1946.

${ }^{108}$ Robert Sherrod, History of Marine Corps Aviation in World War II, (San Rafael, California, 1952), p. 446.
} 
Marines. ${ }^{109}$ Unfortunately, due to Oregon's prevailing poor flying weather, MAG-35 relocated to El Centro, California, in October 1944 where it continued to operate until the end of the war. MAG-35's supporting Navy Hospital in Corvallis continued to operate in processing Navy and Marine casualties from the Pacific until closed in April of 1946.

The Marine Barracks Klamath Falls had an entirely different mission from those concerned with security duties at Astoria and Tillamook and aviation operations in Corvallis. It was a unique experimental therapy and research facility focused on the treatment of Marine veterans suffering from both combat fatigue and two tropical diseases: malaria and filariasis. ${ }^{110}$ Another aspect which made Klamath Falls unique was that due to the 600 plus Marine veterans who chose to remain or return after the war, it is still known today as a "Marine Town."

Due to the large number of American personnel who were deployed to the central and south Pacific, exposure rates to malaria and its companion disease, filariasis (an infection caused by a microscopic worm transmitted by mosquitos), soared by late 1943 . Surveys showed that upwards of $70 \%$ of the Samoan population were infected, with the complication of elephantiasis (swelling of limbs and organs) being common. As Navy medical personnel were unfamiliar with the disease among Caucasians, it was determined

\footnotetext{
${ }^{109}$ Camp Adair Sentry, Volume III, \#2 of 5 May 1944 and Volume III, \#8 of 9 June 1944.

${ }^{110}$ Richard P. Matthews, "Taking Care of Their Own: The Marine Barracks at Klamath Falls, Oregon," Oregon Historical Quarterly, Winter 1992-93, p. 343.
} 

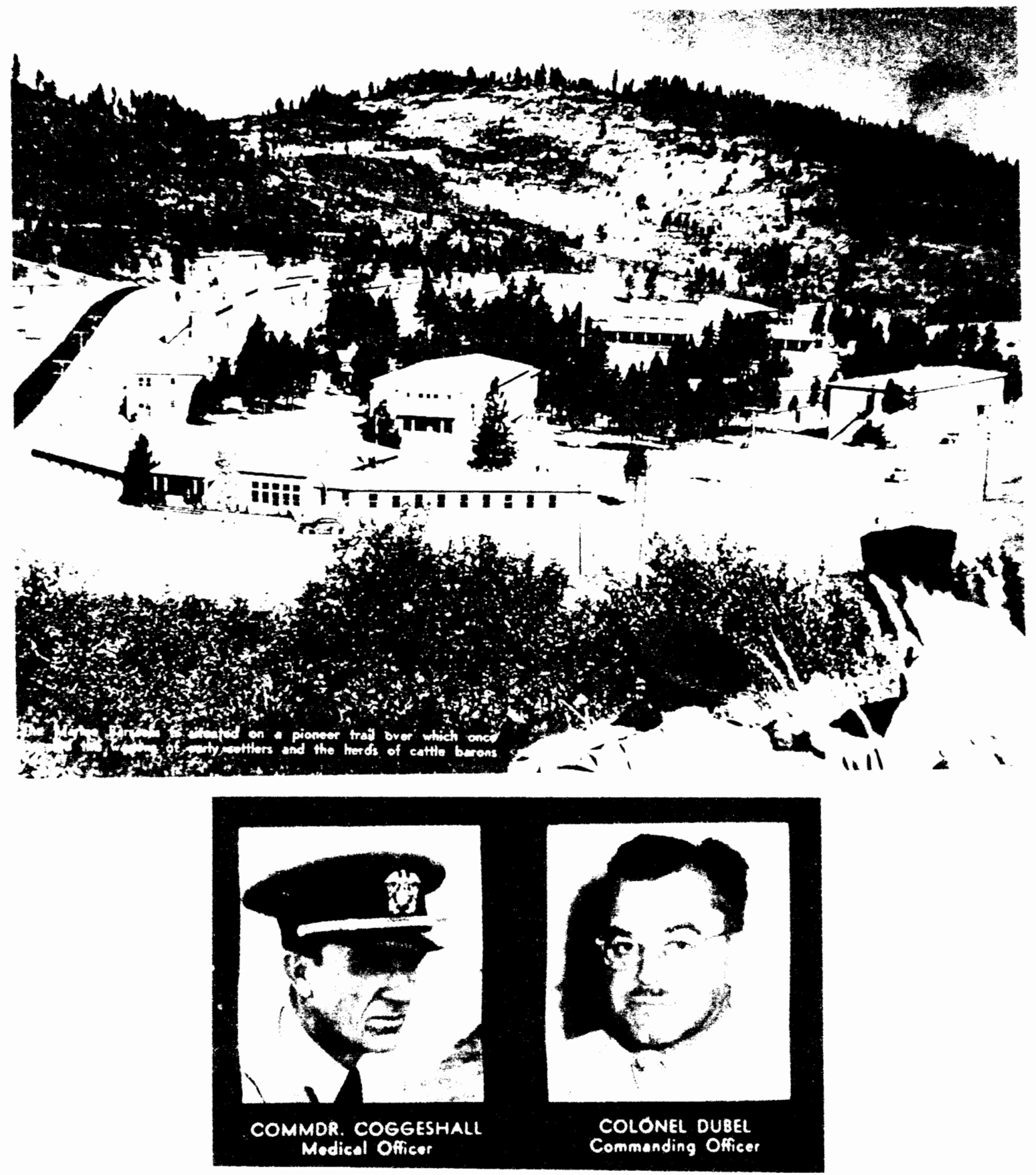

Figure 45 Marine Barracks Klamath Falls, 1944

Figure 46: Commander Coggeshall, senior Navy medical officer and Colonel Dubel. Marine commanding officer, Klamath Falls

Photos courtesy Marine Corps Historical Center 
that a special site for both the study and treatment of these Pacific diseases be established. The logging town of Klamath Falls, Oregon, with a population of 12,000, was chosen due to its 5,000-foot elevation, ideal climate, proximity to a fair size city, and good transportation lines. The Navy was also already familiar with the town through its neighboring Naval Air Training Facility, which had been established in $1943 .{ }^{111}$

Following the approval of the Secretary of the Navy on 27 November 1943, construction of the Marine Barracks Klamath Falls began on 27 January 1944. Located three miles northeast of town with some 80 buildings on 800 acres, its capacity eventually reached 5,000 personnel. Its cost was $\$ 3,500,000.00$. A series of two story barracks, a dispensary, laboratories, mess hall, exchange, chapel, and base quarters were among the main facilities constructed. It also boasted a large gymnasium, bowling alleys, a rifle range, theater, the largest indoor swimming pool in Oregon, and a fine officers' club. On 18 March 1944, Colonel Bernard Dubel USMC, arrived as the first commanding officer. Activation of the facility took place on 5 April 1944 with there being a garrison of 77 Marines and 15 Navy medical personnel there by the end of the month. By 26 May 1944, Commander Lowell T. Coggeshall, US Navy medical corps, had arrived on site as senior medical officer, a position he would retain until deactivation of the base in 1946. Already possessing considerable experience in malaria based upon

${ }^{111} \underline{\text { Ibid. }}$, p. 346. 
his studies at the University of Chicago and field work for Pan American Airlines in China, he soon became the leading Navy expert on tropical diseases. ${ }^{112}$

The first contingent of Marine patients arrived on 27 May 1944. They were very warmly received by the patriotic and hospitable citizens of Klamath Falls, who worked with the staff in dispelling any suggestion that these Marines were convalescents or invalids. This was reinforced officially by Colonel Dubel with his strong practical emphasis on Klamath Falls being an official Marine Barracks. A wide range of challenging Marine physical conditioning, construction, maintenance, security, training, educational, and vocational programs made this clearly evident. This was backed up by a full, wide range of diet, athletics, liberty, and plenty of rest.

By 22 September 1944, Marine Barracks Klamath Falls was officially activated. The average number of Marines stationed here was 2,110 (between April 1944 and November 1945), with the high being 3,410 . The average length of stay was 6-7 months. ${ }^{113}$ By 1944 , the majority of fighting in the Pacific had shifted north, away from the more infected islands, with the result that there were lower numbers of infected Marines. Effective drugs and treatment had been established, resulting in an improved malaria relapse average of $20 \%$. It had also become apparent that filariasis was a minor problem, with only a $3 \%$ reactivation rate. No evidence of elephantiasis was found. The

$$
\begin{aligned}
& { }^{112} \text { Ibid, p. } 347 . \\
& { }^{113} \underline{\text { Ibid., p. } 354 .}
\end{aligned}
$$


latter had had significant psychological impact but a combined program of counseling, examinations, therapy, and supervision eventually cleared up existing misconceptions. A liberal dose of liberty in a very hospitable Klamath Falls on Wednesday and Saturday afternoons, and all day Sunday, was the final cure. Particularly when it was backed by the full participation of the Klamath Falls Commandos, consisting of local high school and college women, who participated in social gatherings hosted by the Home Hospitality Committee of the League of Women Voters. Marine high school completion programs and welding classes were established at Klamath Union High School. Community projects such as fire fighting trail construction, agricultural harvesting, war bond drives, fundraisers, and social events to include hikes, dances, and home visitations were also instituted with success. Marines built a combined forest service, Boy and Girl Scout facility in Winema Forest and named it Camp Govo (after their second commanding officer, Colonel George O. Van Orden, who had taken over from Colonel Dubel in November of 1944). ${ }^{114}$

By 1 September 1945, with the war over, the number of Marines who had passed through Marine Barracks Klamath Falls was 4,739, with only 171 having been medically discharged. None of these were due to malaria or filariasis. ${ }^{115}$ With its mission having been successfully completed and having won national attention for a job well done,

${ }^{114}$ Personal Interview between Thelma Johnson, Associate Life Member Crater Lake Marine Corps Detachment, Chairman 50th Reunion, Former Manager of Leatherneck Club, and author, 4 April 1994.

${ }^{115}$ Matthews, Taking Care of Their Own, p. 361 
Marine Barracks Klamath Falls was no longer needed. Under its third and final commanding officer, Colonel Charles T. Brooks, it was officially deactivated on 28 February 1946. Today, its large and vibrant Crater Lake Detachment of the Marine Corps League are living testimony of the uniqueness and special aspects of this episode of Oregon Marine history.

While these events at Astoria, Tillamook, Corvallis, and Klamath Falls were taking place in Oregon, events in the Pacific had transitioned following Guadalcanal to the point where General Vandegrift stated: "The Japanese never again advanced."116 The Guadalcanal campaign ended on 9 February 1943, when U.S. Army troops secured Cape Esperance. Thus ended a desperate six-month battle of attrition in which 1,504 Marines had been killed and 2,619 wounded. Despite often having had numerical superiority, the Japanese had launched too many piecemeal frontal attacks. They had skillfully been able to extricate 13,000 of their men from Guadalcanal using destroyers at night, but more than 24,000 were killed on the island or died of disease. Marine aviation had lost 118 planes, but shot down 427 Japanese. Each side had lost 24 warships, not to mention dozens of transports, in the long series of primarily night engagements. Almost a quarter of all US Navy ship losses in World War II were in the Solomons, but as Vandegrift stated: "If the surface Navy continues to perform as they have since Admiral Halsey took over, then this place is safe for democracy." 117 The

${ }^{116}$ Heinl, Soldiers of the Sea, p. 376.

${ }^{117}$ Ibid., p. 374. 
Japanese also recognized this in the statement of Captain Ohmae: "After Guadalcanal, I felt we could not win." ${ }^{118}$ For the United States Marine Corps, Guadalcanal had all of the significance of another Belleau Wood, for here also, the fighting qualities of the individual Marine had provided the margin of victory.

Brutal struggles lay ahead however, and the Battle of Tarawa from 20-23 November 1943 marked the next significant Marine step in the Pacific. Tarawa had first been visited by U.S. Marines of the famous Wilkes expedition one hundred years previous. At the Casablanca conference (January 1943) attended by President Roosevelt, Prime Minister Churchill, and the Combined Chiefs of Staff, Admiral King's strategic concept of an offensive in the Central Pacific was accepted. This was done in light of reservations by General Marshall and especially General MacArthur, who believed any advance on Japan except via the Philippines was sacrilegious. The Allies would now mount two mutually supporting Pacific drives to apply "unremitting pressure against Japan."119

Admiral Nimitz now created the Central Pacific Force, which comprised the Fifth Fleet headed by Vice Admiral Spruance (victor of Midway) with Rear Admiral Mitscher's carrier task force, Rear Admiral Turner's Fifth Amphibious Force (whose mission was to transport, land, and support Marines), and Major General "Howlin Mad" Smith's V Amphibious Corps. When Commandant Holcomb made his assignment of Smith to this

${ }^{118}$ Ibid., p. 376.

${ }^{119}$ Ibid., p. 405. 
position, he reportedly observed to his staff: "He's the only general I've got who can shout louder than any admiral."120

Smith launched his attack on Tarawa with 2nd Marine Division against 4,836 heavily dug in and prepared Japanese naval troops (sometimes referred to as Imperial Marines). The Japanese commander had boasted that Tarawa could not be taken by a million Americans in a hundred years ${ }^{121}$ Ferocious fighting took place over the next 76hours in which 991 Americans were killed and 2,311 were wounded. Japanese killed were almost 4,700. It was here that Corporal Harry Niehoff (mentioned earlier) won his Silver Star on Red Beach 3 with Company A, 2nd Engineer Battalion in support of 2nd Battalion, 8th Marine Regiment, with 2nd Marine Division. Behind Niehoff was his close friend and fellow engineer, Sergeant Harold $\mathrm{H}$. White, who amid enemy fire, operated an open, unarmored TD-18 bulldozer in burying Japanese bunkers. The four operators who had been hit before him were the prime motivation for the Marine Corps later having armored cab kits installed back in Hawaii on dozers intended for forward assault elements. These would later be successfully employed on Saipan, Iwo Jima, and Okinawa. It was also here that Captain Lyle E. Specht, who was born in Silverton, Oregon, also won a Silver Star as the commanding officer of Company D, 1st Battalion, 6th Marine Regiment. At 0400 on the morning of 24 November 1943, his unit was charged in the dark by 200 screaming Japanese led by sword swinging officers in a

${ }^{120}$ Ibid., p. 406.

${ }^{121}$ J. Robert Moskin, The U.S. Marine Corps Story, (Boston, 1977), p. 295. 


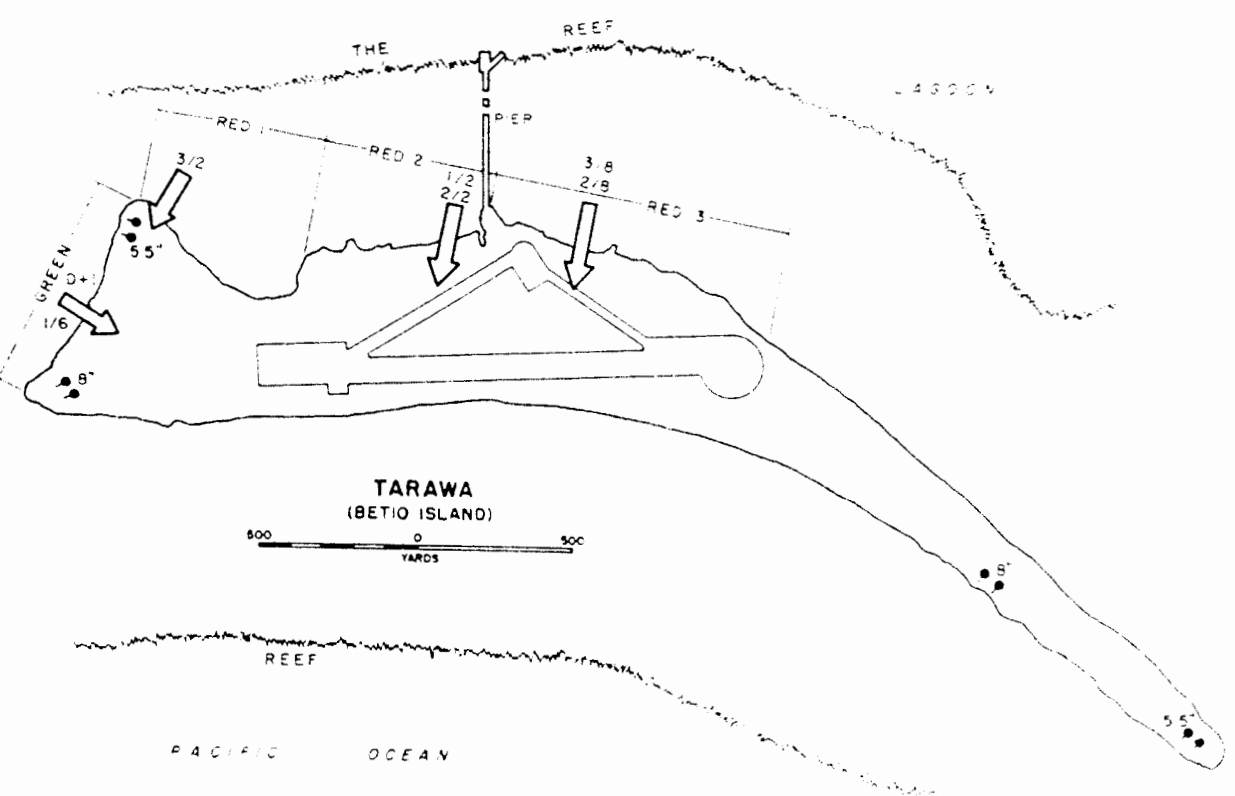

Betio Assault, Gilbert Islands, 20-21 Notember 1943.

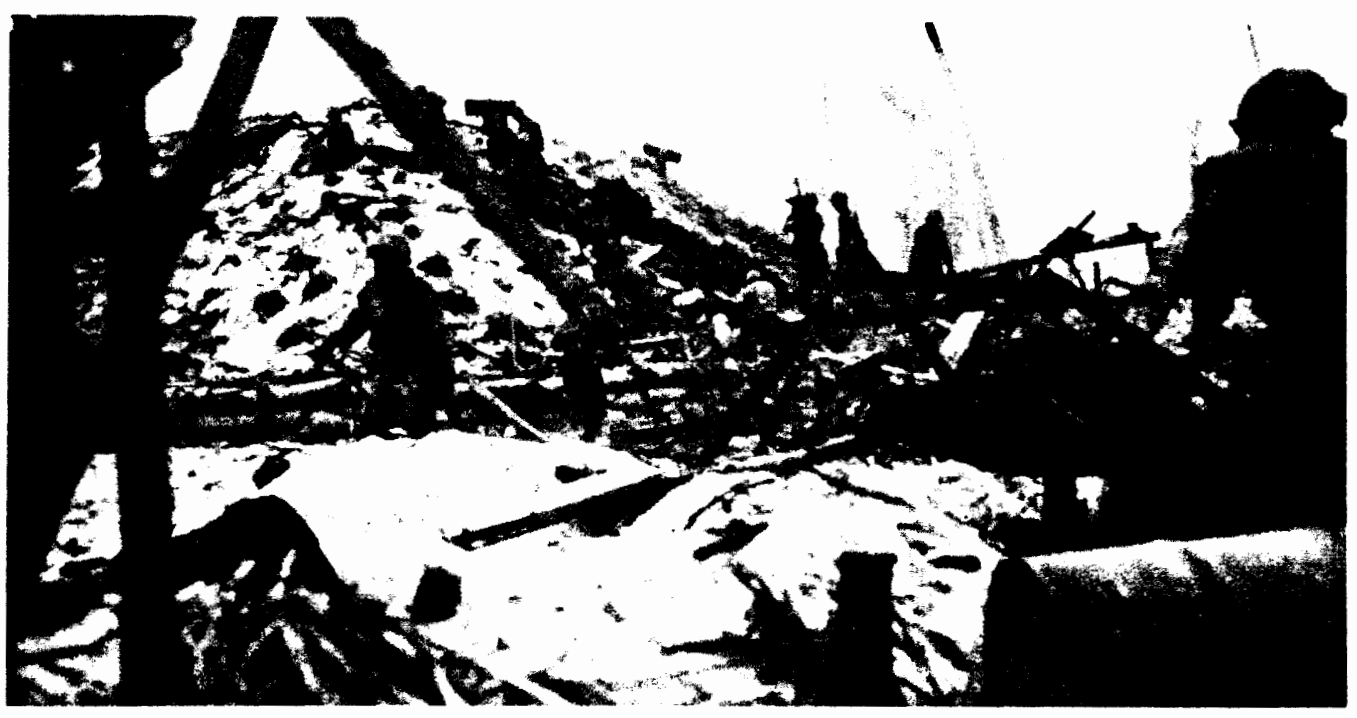

Figure 47 Map of Tarawa Island, Gilbert Islands, November 1943.

Soldiers of the Sea by Heinl, p 408

Figure 48. Harry Niehoff, of Portland (center of picture carrying more explosives forward), and other Marine combat engineers in support of 2nd Battalion, 8th Marine Regiment on Red Beach 3 of Tarawa

Tarawa The Toughest Battle in Marine Corps History by Dick Hannah, U.S Camera Publishing Co., 1944, p. 89 
desperate final banzai attack. Specht personally led his Marines in killing all of the Japanese with machine guns, grenades, and fixed bayonets.

Another Oregon veteran of the brutal assault on Tarawa was Bernard Wyman Gerber. Born in Bethany, Oregon on 24 April 1915 to Swiss immigrants who founded Bethany Baptist Church, "Bennie" Gerber was a farmer who in June 1942, entered the Old Courthouse of Portland (just off of today's Pioneer Square), went up to the 4th floor, turned left, and signed up with nine others standing in the hallway. By that same evening, Gerber had undergone his physical and was on a train bound for Camp Elliott, near San Diego. Following six weeks of bootcamp and qualification on the 1903 Springfield rifle, in August of 1942, Gerber was assigned to 3rd Platoon, Company B, 1st Battalion, 8th Marine Regiment of the 2nd Marine Division. Following a twenty-one day passage to Wellington, New Zealand, an arduous training program centered on long hikes took place. On Tuesday morning 20 November 1943, Corporal Gerber found himself with his M-1 rifle wading across a bullet swept lagoon from a Higgins Boat to the Tarawa shoreline. From here, the grueling struggle of overcoming a continuous series of Japanese fortifications took place. Gerber and 1st Battalion, 8th Marines attacked west eventually clearing that portion of the island, despite heavy casualties, by Thursday 22 November 1943, Thanksgiving Day.

His worst memory was of his buddies getting hit while crossing the lagoon in chest deep water, where planners had incorrectly judged the tides. He vividly recalls that in suppressing Japanese machine gun bunkers, the Marine "flame throwers did a pretty 
good job." Gerber also recalls the mixed feelings following the battle, when despite being safely aboard ship, being witness to the many burials at sea. Following a second landing at Tinian in June 1944, Sergeant Gerber was later honorably discharged from the Marine Corps in November $1945 .{ }^{122}$

Four hundred miles east on Bougainville beachhead at the northern end of the Solomon Island chain, Lieutenant Colonel John C. Machamer, of Portland (mentioned earlier) was also occupied in November of 1943. The Sunday Oregonian of 5 December 1943 ran an article entitled: "Marines Make Jungle Abodes" in which the Associated Press spoke of Machamer as the "Portlander in Charge" of constructing superb base camps for 3rd Marine Division and 3rd Raider Battalion. In describing the jungle here as "ripe, thick, boggy, hot, and wet" it emphasized the success of his efforts in transforming Bougainville into a descent place to live. It stated: "Where Americans go, regardless of handicap, they bring in the touch of civilization and the skill of building and after awhile you have a rough camp and then a village and finally you even get ice and beer and fairly recent newspapers."

With the conquest of Tarawa and the Gilbert Islands, the main American focus was directed toward the Mariana Islands, which Admiral King considered to be key to the western Pacific. Many lessons had been learned regarding Tarawa, and Admirals King and Nimitz approved many of the command and control innovations proposed by

\footnotetext{
June 1994.

${ }^{122}$ Personal Interview between B. W. Gerber and author, Portland, Oregon, 2
} 
General Smith. Chief among these was backing the Marine Corps in its contention that the landing force commander would land and assume full control of fighting ashore, thus curbing Admiral Turner (who Smith stated: "always had suppressed ambitions to be a general"). It also prevented a serious attempt by the US Army (who believed Marines to be "inexperienced and untrained" in corps staff duties), from assigning an Army corps headquarters to replace Smith and his V Marine Amphibious Corps staff. ${ }^{123}$ These modifications resulted in the relatively easy seizures, in February of 1944, of the important staging areas of Kwajalein, Roi-Namur, and Eniwetok atolls in the Marshall Islands. Eniwetok Atoll alone was a superb anchorage and one of the most magnificent lagoons in the world. The strategic timetable of the war had been advanced by almost half a year, and the way was now clear for the conquest of the Marianas. ${ }^{124}$ In recognition of this, Secretary of the Navy Knox promoted "Howlin Mad" Smith with a third star to Lieutenant General.

By the close of 1943, the Marine Corps had continued to evolve in its structure and grow to 391,620, serving in four Marine Divisions, four air wings, and 19 defense battalions. Among these were 13,201 Women Marines. Change is not always easy for an institution long on warrior tradition, and this did not win approval in all quarters. Commandant of the Marine Corps, General Holcomb, later related that on the day in February 1943 when he approved the Women Marine program, the picture of Archibald

\footnotetext{
${ }^{123}$ Heinl, Soldiers of the Sea, p. 419-420.

${ }^{124} \underline{\text { Ibid. }}$, p. 428.
} 
Henderson (who had been the singularly unique and stalwart Commandant from 1820 to 1859) crashed to the floor in the Commandant's House. The first African-Americans had also been accepted into the Marine Corps in 1943 (comprising the 51st and 52nd Defense Battalions), and would be fully integrated throughout the Corps within a decade. Also for the first time since 1919, the Corps included draftees, which despite no dearth of volunteers, were imposed on it. Still one other change took place, for in January 1944, General Vandegrift, who had receive the Medal of Honor for his tenacity at Guadalcanal, became the 18th Commandant of the Marine Corps. From his outstanding predecessor, General Holcomb, he inherited a fighting organization which had proven itself second to none.

In Oregon, another small but important aspect of Marine Corps support for the war effort took place. During April of 1944, a Marine Training Detachment from Southern California was temporarily stationed at Camp Adair, near Corvallis, Oregon. The mission of this unit was to provide Army-Navy joint amphibious instruction to the staff of the 96th Infantry Division. This Army unit would later apply these lessons in making landings both at Leyte in the Philippines, and at Okinawa. Along very similar lines, it is important to point out that the same detailed type of amphibious instruction by Marines was being provided to the Army under the leadership of officers such as Lieutenant Colonel R. O. Bare. This Marine not only helped plan, and coordinate amphibious doctrine for the Army, but participated in the Normandy landings. This was 
the largest amphibious landing operation in history, despite Marine veterans of countless Pacific landings referring to it as simply a "cross channel ferry operation."

In the Pacific, increasingly more pressure was being placed on Japan. At dawn on 15 June 1944, General "Howlin Mad" Smith's V Amphibious Corps, comprised of the 2nd and 4th Marine Divisions, assaulted abreast on the southwestern shore of Saipan, Japan's headquarters in the Marianas. Despite fierce resistance from 30,000 Japanese troops, the Marines fought their way a mile inland by dusk.

On 17 June 1944, Captain Lyle E. Specht, of Silverton, Oregon (already mentioned earlier for his Silver Star on Tarawa), earned the Navy Cross on Saipan. Now in command of Company B, 1st Battalion, 29th Marine Regiment, of 4th Marine Division, Specht exercised leadership, initiative, and courage in seizing a ridge to cover his battalion's exposed right flank. Despite heavy mortar and machine gun fire which drove his men to withdraw to a nearby reverse slope, he personally rallied his Marines in retaking the ridge and repelling the subsequent counterattack by a strong Japanese unit. Specht, a graduate of Oregon State University and known to his friends as "Spook," would later not be so lucky during the Battle of Okinawa, when with Company B, 1st Battalion, 29th Marine Regiment (now serving with 6th Marine Division), he was hit by Japanese machine gun fire. He would recover to eventually retire as a colonel in Tillamook, Oregon.

Another Portland Marine on Saipan was Corporal David W. Dowdakin of Company I, 3rd Battalion, 2nd Marine Regiment, 2nd Marine Division. Having joined 


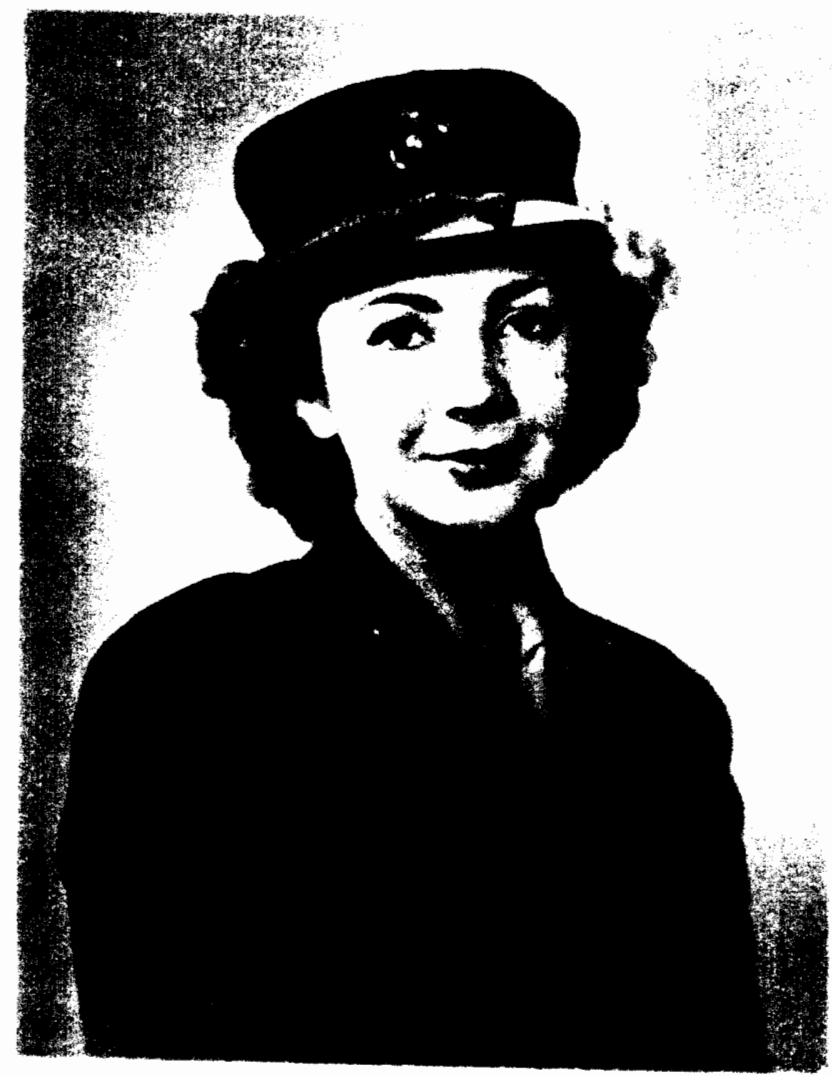

Figure 49: Corporal Dixie Turner McKendrick, who was born in Hillsboro, Oregon on 7 March 1924 and graduated from Nestucca Union High School, followed a long and proud Women Marine tradition in Portland, Oregon The first known Woman Marine or "Marinette" of the World War I period was Elizabeth "Bessie" Welke, who was transferred from the East Coast to Portland in 1917 to work as an administrator for the massive World War I recruiting effort. During World War II this tradition of Woman Marine service continued when Staff Sergeant Catherine "Kay" Wilson Haedinger was assigned to the Portland Recruiting Station from Los Angeles. Haedinger actually recruited McKendrick, who worked as a switchboard operator at Naval Air Station Tillamook and as a recruiter in Portland. McKendrick was discharged from the Marine Corps at Henderson Hall, Virginia, on 27 June 1946. She returned to Portland, married, and eventually raised a family of seven children.

Photo courtesy of Dixie Turner McKendrick Collection. 


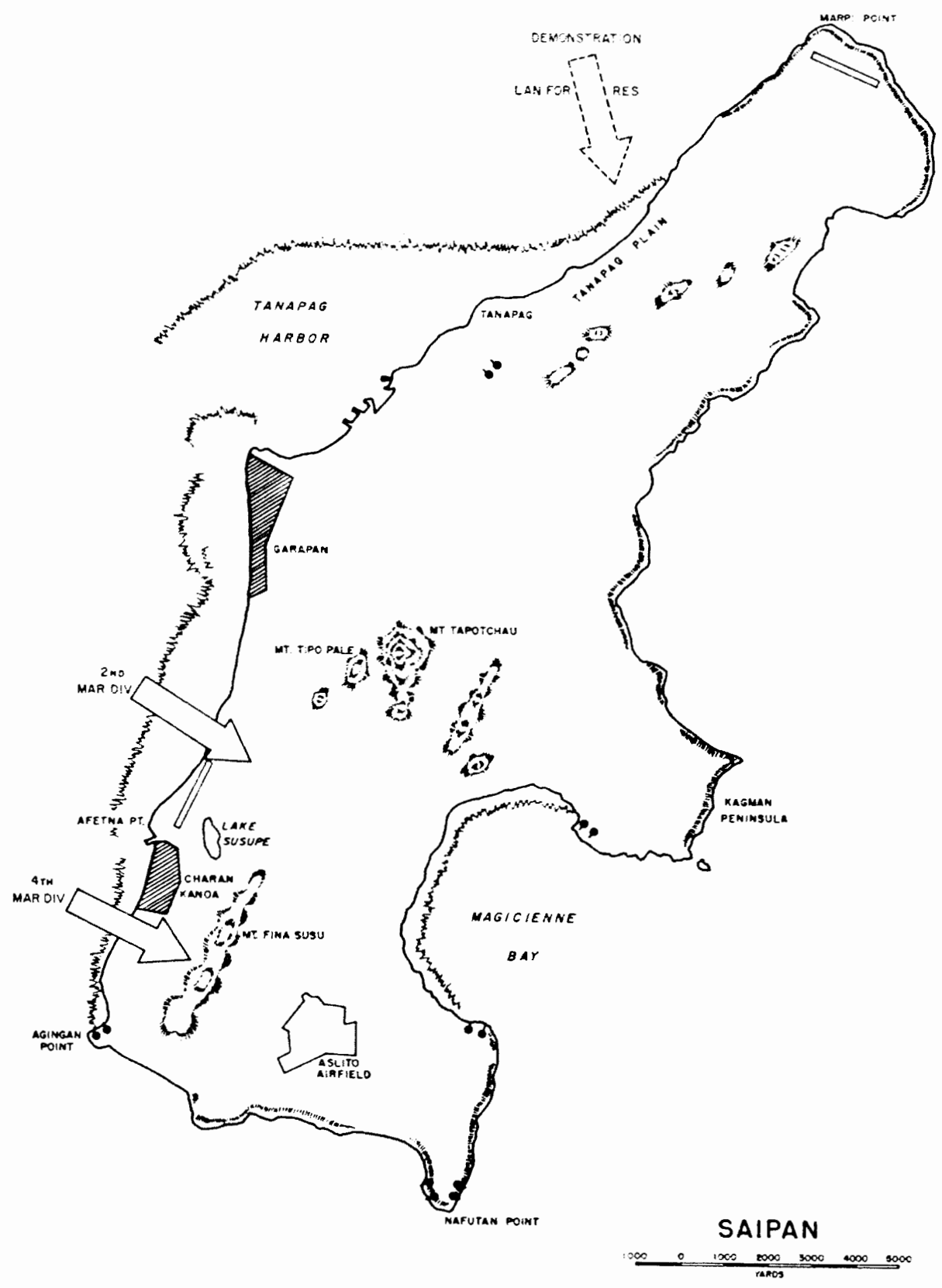

Landings on Saipan, Mariana Islands, 15 June 1944.

Figure 50: Map of Saipan, Mariana Islands, June 1944.

Soldiers of the Sea by Heinl, p. 435. 


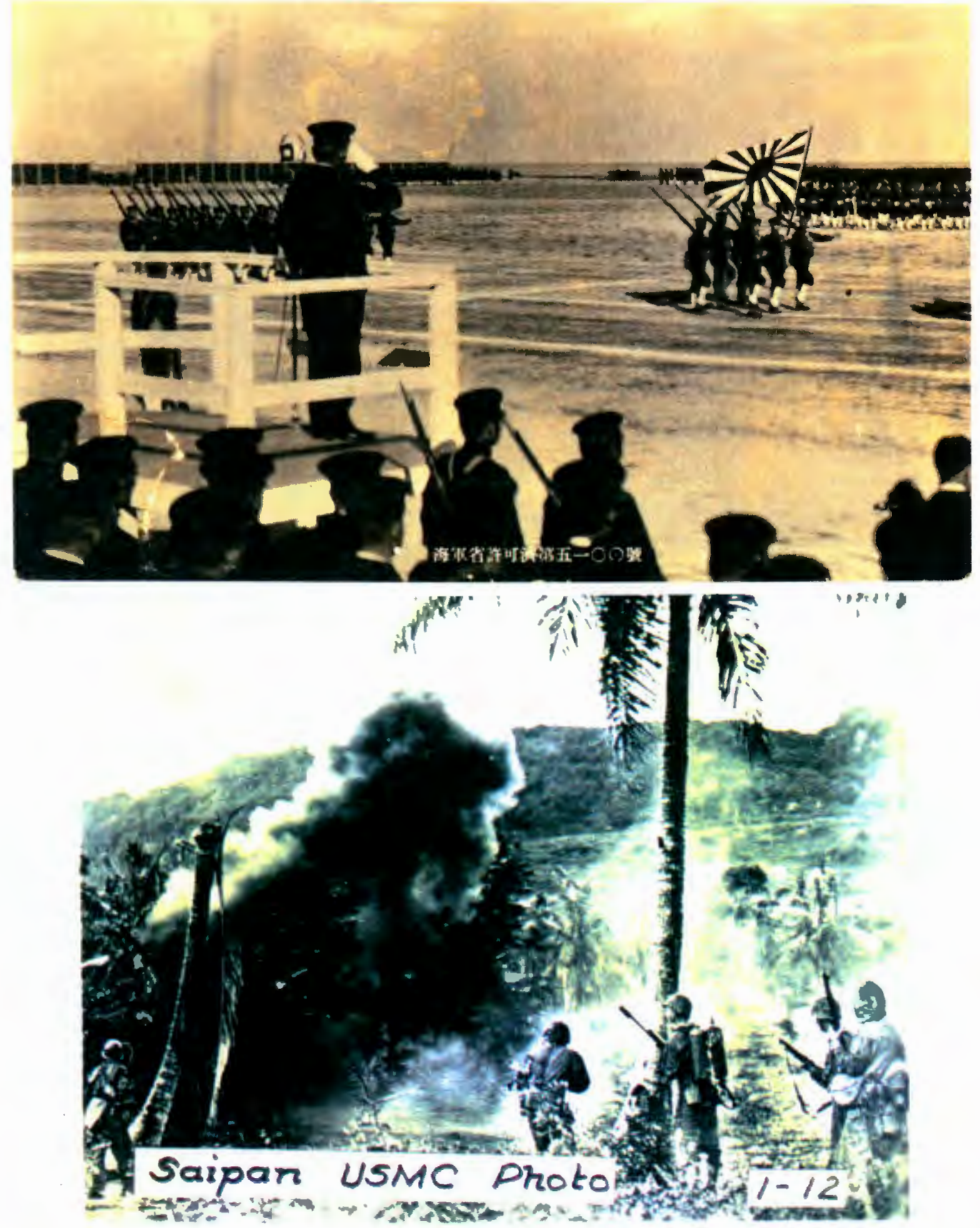

Figure 51: Liberated Japanese photo of Imperial Naval Landing Forces (Japanese Marines) on Saipan prior to American invasion.

Figure 52: Company A, 2nd Engineer Battalion, 2nd Marine Division in action on Saipan. Note demolitions man on left and flamethrower operator to right.

Photos courtesy of Harry H.W. Niehoff Collection 
the Marine Corps on 30 September 1942, he was a veteran of bloody Tarawa (H\&S Co. 2nd Marines). Dowdakin earned a Purple Heart Medal on Saipan when his unit fought from the Red Beach to Garapan where he was wounded by a booby trap. At the end of the operation, Company I had had its commander, three platoon leaders, its platoon sergeant and 36 other Marines all killed in action. Dowdakin would be present for the 1 April 1945 2nd Marine Division demonstration off of Okinawa, where his ship, LST 884 , was destroyed by a kamikaze, resulting in 25 Marines being killed. Dowdakin was discharged as a Sergeant on 29 September 1945 in San Diego, but would later see service in Korea. ${ }^{125}$

Saipan was the first of the Japanese held Mariana Islands to be captured by American forces. In a bitter campaign lasting from 15 June to 9 July 1944, Japanese resistance was crushed, and American B-29 bombers were now within range of mainland Japan. 29,000 Japanese troops were killed on Saipan, together with 3,426 Americans, mostly Marines. On 21 July 1944, 3rd Marine Division and 77th Infantry Division landed on Guam against 19,000 Japanese troops. By 10 August 1945, all Japanese resistance was eliminated at the cost of 1,023 Americans dead. Meanwhile, on 24 July 1944, 4th Marine Division landed on the northwest shore of Tinian, while 2nd Marine Division made a successful feint off of the southwest coast and later came in behind 4th Marine Division to assume the advance down the east coast. By 31 July, Tinian was secured

\footnotetext{
${ }^{125}$ Personal Interview between D.W. Dowdakin and author, Portland, Oregon, 3 October 1994.
} 
with virtually the entire 9,000 man Japanese garrison having been eliminated, at the cost of 327 Marines killed, 1,771 wounded.

The conquest of the Marianas resulted in the death of over 40,000 Japanese troops, a disastrous Japanese navy counterattack in the Philippine Sea to the west, and the fall of the Japanese government of Prime Minister and General Hideki Tojo. On 24 November 1944, the first American B-29 raid on mainland Japan was launched from Saipan. By 1945, Tinian would be the largest American airbase in the world, regularly launching B-29 raids against Japan. It would also launch America's first nuclear strike. Of additional note should be "Howlin Mad" Smith's strident accolade for the US Navy submarine service, which made a significant contribution toward the saving of Marine lives through the sinking of considerable Japanese supplies of barbed wire, concrete, and vast amounts of other construction materials.

15 September 1944 marked the start of a controversial Marine campaign which is still debated: the invasion of Peleliu by the 1 st Marine Division. The main question is whether or not Peleliu was necessary to secure MacArthur's right (eastern) flank for his upcoming invasion of the Philippines. Admiral Halsey had strongly urged that it be called off. Peleliu was 550 miles to the east, in the Caroline Islands, and it was stoutly defended by 10,000 Japanese troops entrenched in over 500 fortified caves and interconnecting strong points. Despite the usual heavy air and naval bombardment (one of the cruisers providing fire support was the USS Portland), 1st Marine Division, upon landing on the southwest shore, was immediately slowed by savage Japanese resistance. 
Peleliu cost the highest casualty rate (almost $40 \%$ ) of any amphibious attack in American history, with 1st Marine Division suffering 1,252 killed among 6,526 total casualties. Japanese casualties, which included reinforcements from nearby islands, stood at 13,600 killed and 400 captured. Among the later was the able General Sadae Inoue, the capture of whom was an unprecedented occurrence in Pacific fighting.

It was here on Peleliu that the first Marine from Oregon received the Congressional Medal of Honor. Private First Class Arthur J. Jackson, of Portland, Oregon, was a rifleman with Company I, 3rd Battalion, 7th Marine Regiment of the 1st Marine Division. He had attended Grant High School in Portland, and joined the Marine Corps on 11 January 1943. He had been with his unit during the Cape Gloucester, New Britain campaign, where he received a Letter of Commendation for carrying a wounded Marine to safety while under heavy fire. Now on Peleliu, Jackson was confronted 18 September 1944, with his platoon's left flank being help up by an extensive series of Japanese fortified positions. First, he boldly assaulted a large bunker containing 35 Japanese troops, and hurled white phosphorous grenades and explosive charges into it, killing all the occupants. He then continued to advance alone against two other neighboring enemy fortifications, which he eliminated through similar efforts. Determined to crush the entire defensive network, Private First Class Jackson, while under fire from three sides, employed additional explosives to wipe out a total of 12 fortifications and kill over 50 Japanese. Wounded in the neck on 21 September 1944, he recovered in time to rejoin his unit as a corporal for the Battle of Okinawa. Here he 


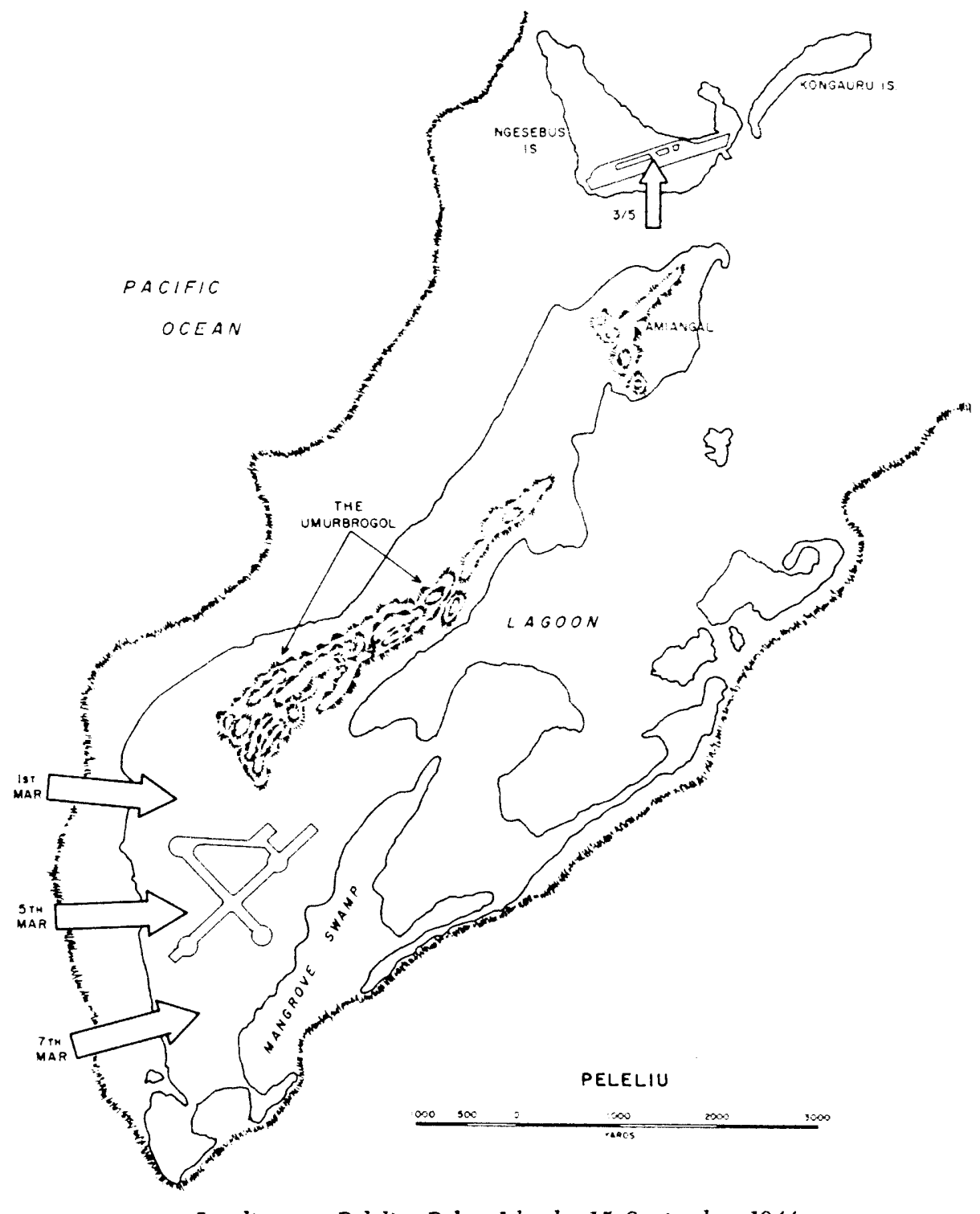

Landings at Peleliu, Palau Islands, 15 September 1944.

Figure 53. Map of Peleliu, Palau Islands, September 1944

Soldiers of the Sea by Heinl, p 467 
was promoted to sergeant and promptly received his second Purple Heart when shot in the neck a second time on 18 May 1945 . Recovering enough to receive a field commission, he was evacuated on 21 May 1945. He later received his Medal of Honor personally from President Truman. In August and September of 1945, he was stationed at Marine Barracks Klamath Falls, Oregon for participation in the malaria research program. Captain Jackson later ended his Marine Corps career on 17 March 1962, in Camp Lejeune, North Carolina. Jackson later stated that: "Despite the hell and hardship, the comraderie, esprit de corps, and determination to win while protecting and defending one another is my fondest Marine memory." 126

On 1 November 1944, an event took place back on Guadalcanal, which would later have a significant historical and traditional impact on future Reserve Marines in Oregon. This was the activation of the 6th Engineer Battalion. It was formed as a part of the new 6th Marine Division, which was placed under the able command of a distinguished Belleau Wood veteran, now Major General Lemuel C. Shepherd Jr. Destined to later become the future 20th Commandant of the Marine Corps, he had as a First Lieutenant in France, shared the 54th Company, 1st Battalion, 5th Marines, with First Sergeant John Page of Portland, who had retired in 1941 as Oregon's First Marine Sergeant Major. Still another interesting twist to this circle is that General Shepherd, a native of Norfolk, Virginia, graduated from Virginia Military Institute with a degree in

\footnotetext{
${ }^{126}$ Personal Interview between A.J. Jackson and author, Portland, 14 January 1994.
} 
civil engineering. He would later choose an officer from 6th Engineer Battalion, First Lieutenant Daniel Thornton, as his aide. It is indeed a small world, and an even smaller Marine Corps.

Meanwhile, the frequent B-29 bombing runs against Japan from the Marianas had focused attention on the eight square mile, volcanic island of Iwo Jima. Lying only 660 miles, midway between the two, the capture of Iwo Jima would not only eliminate it as a menace to these strikes, but allow American fighters to escort the B-29's to and from Japan. It would also serve as an emergency landing field for damaged aircraft.

Japan also appreciated the importance of Iwo Jima. One of her finest officers, General Tadamichi Kuribayashi, was given command of its 21,000 man garrison. Having served before the war in both the United States and Canada as a defense attache, Kuribayashi had a sound appreciation for American capabilities, firepower, and tactics. On Iwo Jima, an island $43 / 4$ miles long by $21 / 2$ miles wide, he constructed the most formidable defenses ever to be encountered in World War II. His defenses consisted of 1,500 fortified caves, hundreds of concrete bunkers, blockhouses, and pillboxes, connected by over 16 miles of tunnels. All Japanese on Iwo Jima were forbidden to launch sacrificial banzai charges, which had up to this point in the war, merely played into the hands of superior American firepower. Kuribayashi's planned strategy was confirmed by a German general staff study done at the request of Japan. Iwo Jima was painstakingly planned to be as prolonged and arduous a battle of attrition as possible. 


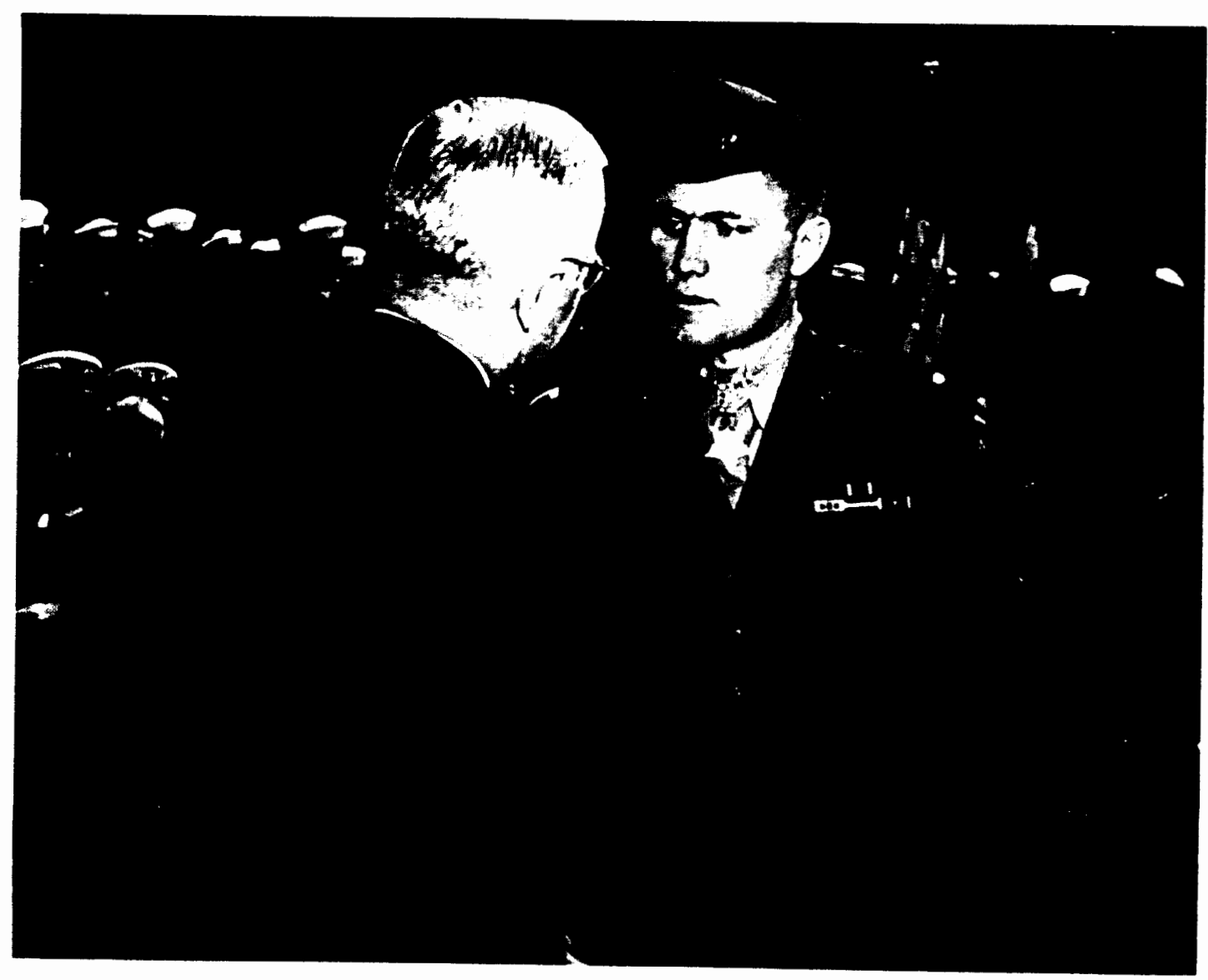

Figure 54. Arthur J Jackson, of Portland, receiving the Medal of Honor for his actions at Peleliu from President Truman

Photo courtesy of Arthur J Jackson Collection 
For the Marine Corps, Iwo Jima would be the supreme test of leadership, courage, amphibious doctrine, tactics, and equipment. It would also be the most costly.

On 19 February 1945, the largest Marine Corps force ever assembled, landed on the southeast beaches of Iwo Jima. The next 36 days would be the bitterest struggle ever faced by Marines. General "Howlin Mad" Smith had with him over 60,000 Marines comprising the 3rd, 4th, and 5th Marine Divisions. Months of frequent aerial bombardment and three continuous days of heavy naval gunfire ("Howlin Mad" had asked for eight, but lost out due to the upcoming Okinawa campaign), had preceded the landing. Despite this, the two lead divisions (4th Marine Division on the right, 5th Marine Division on the left) were soon met by a constant hail of Japanese artillery, mortar, and machine gun fire. On the first day alone, frightful losses were suffered of 600 Marines killed and 1,800 wounded. Both divisions pushed forward against heavy opposition. Basilone was killed on the first day. 5th Marine Division cut across the narrow southern neck of the island, sending one regiment to the left (toward 550-foot Mount Suribachi), while the other two regiments turned right. 4th Marine Division battled across Airfield \#1 and turned right toward the northeastern 382-foot plateau.

Corporal Harrell George Sellers of Portland was serving as a forward observer with the Reconnaissance Platoon of Headquarters Battalion, 27th Marine Regiment of 5th Marine Division. He landed on Iwo Jima 19 February 1945 and moved across the island until being wounded in the back by mortar shrapnel on 5 March near Airfield \#1. He was evacuated to Mobile Hospital 5 on Guam. Recovered, Sellars rejoined his old 
outfit for garrison duty at Sasebo, Japan and was discharged in San Diego, 14 December 1945. ${ }^{127}$ Daily battalion progress was often measured in hundreds of yards, as preregistered Japanese direct and indirect fire continued to rain down on Marine positions. At approximately 1015 on the morning of 23 February 1945, First Lieutenant Harold G. Schrier, the executive officer of Company E, 2nd Battalion, 28th Marine Regiment of the 5th Marine Division, led a 40-man combat patrol to the top of Suribachi. A small flag $\left(41 / 2^{\prime} \times 21 / 3^{\prime}\right)$ was raised at about 1020 in which Marines posed for a picture by Sergeant Louis R. Lowery of Leatherneck Magazine. At about 1430 in the afternoon, a much larger flag $\left(8^{\prime} \times 41 / 2^{\prime}\right)$ was prepared for raising as the first was brought down. As five Marines and one Navy corpsman struggled to raise the second flag, Joe Rosenthal of the Associated Press took an unposed picture. This soon became the most famous and dramatic photograph in American history. Three of the five Marines would later be killed on Iwo Jima.

One Marine struggling to accomplish his unit's mission on Iwo Jima was Captain Harold C. Montgomery, of Portland, Oregon. Commissioned in Quantico, Virginia, on 18 July 1942, he was a veteran of the Marshall Islands fighting in the Kwajalein and RoiNamur campaign. Coming ashore on Iwo Jima with the 4th 155 Howitzer Battalion, 1st Provisional Field Artillery Group, Montgomery struggled amid heavy artillery and mortar fire to get his guns, ammunition, and supplies up the sandy, rugged beaches. His skill

${ }^{127}$ Personal Interview between H. G. Sellers and author, Portland, Oregon, 5 October 1994. 


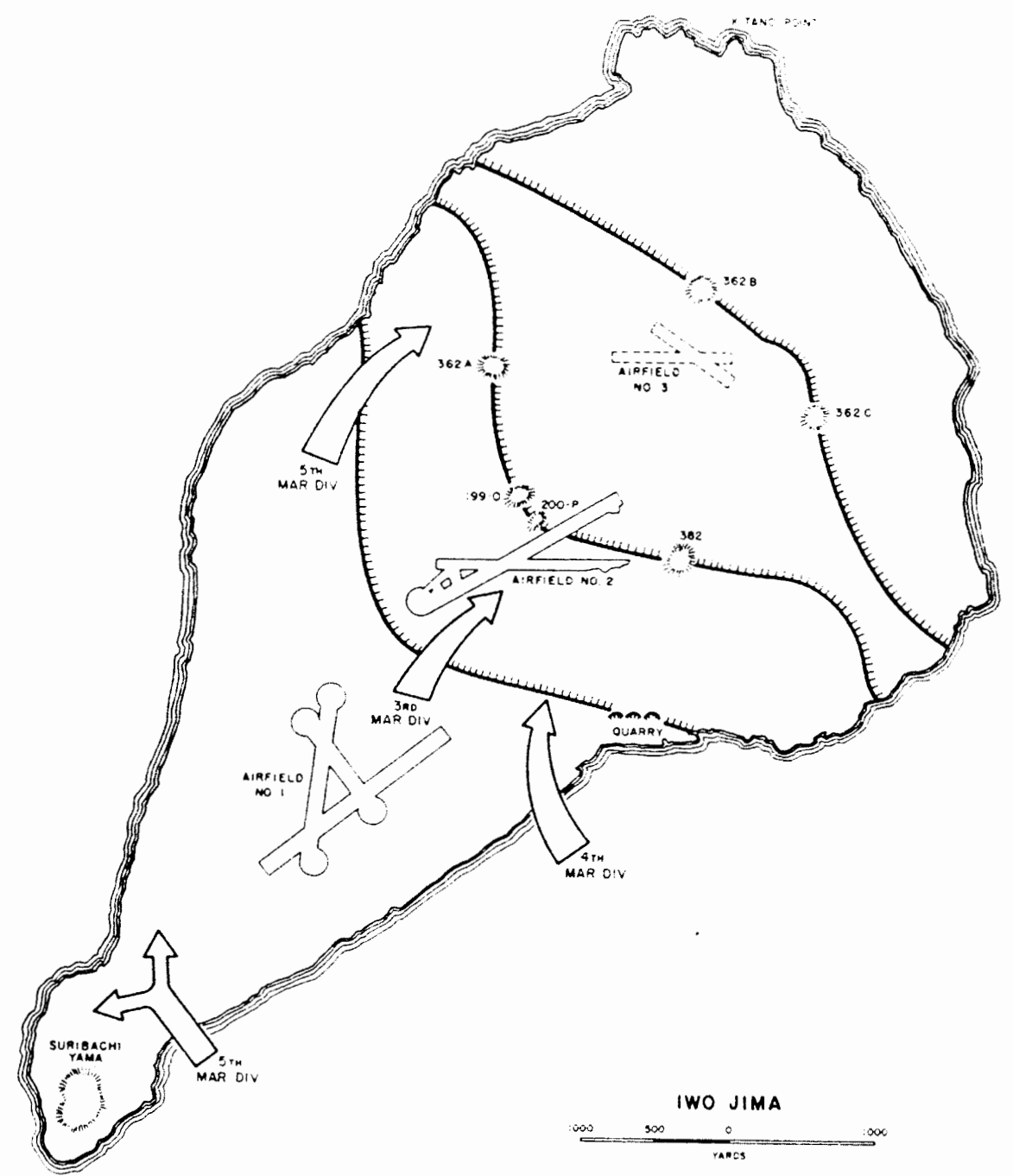

Battle for Iuo Jima, Volcano Islands, 19 February to 15 March 1945.

Figure 55. Map of Iwo Jima, Volcano Islands, February 1945

Soldier of the Sea by Heinl. p. 479 
and devotion in helping to mount effective counterbattery fire against Japanese artillery positions resulted in him receiving the Bronze Star. He would in April 1947, be the first Marine officer assigned to Inspector-Instructor (advisory) duty with the Marine Corps Reserve in Portland, Oregon. He retired and returned to Portland as a Lieutenant Colonel on 18 November 1979.

Everywhere, the Japanese conducted an intelligent and dogged defense from their well disposed and deeply entrenched positions. Marine advances bogged down. As an example, 2nd Platoon, Company B, 1st Battalion, 28th Marine Regiment of 5th Marine Division, a unit originally of 41 Marines, commanded by one officer (a second lieutenant), went through 12 such platoon commanders by the end of the fighting. 2 nd Battalion, 28th Marine Regiment suffered 750 casualties out of a battalion of 900 Marines. Five rifle battalion commanders were killed leading their men. By 0700 on the morning of 25 February 1945, "Howlin Mad" committed 3rd Marine Division to landing and driving up in support between 5th Marine Division on the left flank (north) and 4th Marine Division on the right (south). All three now pushed northeast toward Kuribayashi's headquarters near Kitano Point.

Another of those leading his Marines forward on Iwo Jima, was Sergeant Hubert Joseph "Bert" Faltyn, of Salem, Oregon. Having joined the Marine Corps as a private in October 1940, Faltyn was a veteran of Company D, 2nd Marine Raider Battalion (known as "Carlson's Raiders"), commanded by Lieutenant Colonel Evans Fordyce Carlson of Brightwood, Oregon. The executive officer of "Carlson's Raiders" (not to be 
confused with the 1st Marine Raider Battalion or "Edson's Raiders") happened to be Major James Roosevelt the President's son. Corporal Faltyn served with this unit at the battles of Midway, Guadalcanal, and Bougainville. When the Marine Raider battalions were disbanded and reorganized, his unit became Company D, 2nd Battalion, 26th Marine Regiment of the 5th Marine Division. On Iwo Jima, he assumed command of the company as a sergeant from 13 to 16 March 1945, when all company officers had become casualties. While under intense enemy fire, he moved among his three platoons, giving orders and encouraging his men in their advance on a series of fortified Japanese positions. He reorganized the depleted unit and led it in seizing the difficult objective. Still, under enemy fire, he then directed a dozer tank in the building of a combat trail toward Japanese lines. Although shot through the left shoulder on 14 March 1945, he remained in command and directed flamethrower tank support in leading his Marines in a long advance against another series of enemy caves and pillboxes. Sustaining grenade wounds on 15 March 1945, he remained in command. Sergeant Faltyn then led his company through mortar and rifle fire up a rocky hill overlooking the ocean to their left. Gaining the objective, he organized a hasty defense until his unit was relieved 24 hours later. Faltyn later stated: "Those boys at Iwo were ones I was with in Carlson's Raiders. I just didn't want to leave them." ${ }^{128}$ For his "courageous leadership, indomitable fighting spirit and gallant devotion to duty," Sergeant Faltyn was awarded the Navy Cross, two

${ }^{128}$ Personal Interview between H. J. Faltyn and Author, Salem Oregon, 29 November and 7 December 1993. 


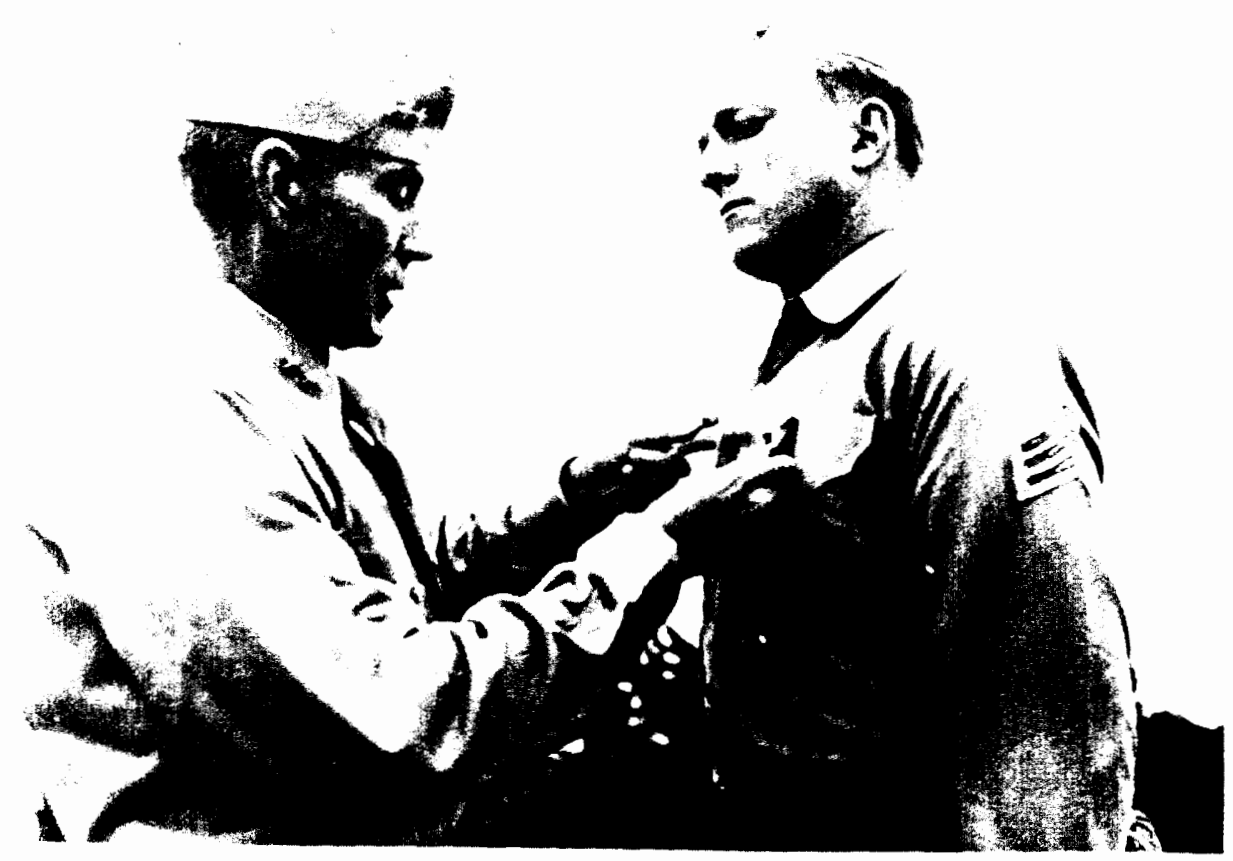

Figure 56: Hubert J. Faltyn receiving the Navy Cross for his actions on Iwo Jima from Major General Rockey the commanding general of 5 th Marine Division at Iwo.

Photo courtesy of Hubert L Faltyn Collection 
purple hearts, and a battlefield commission. He would later be one of the original officers serving after the war in the Salem Reserve unit (Battery C, 4th 105th Howitzer Battalion). Activated in 1950 for the Korean War, he returned in 1953, serving through the lean manpower years and commanding the "Salem Marines" (redesignated following Korea as 3rd 155 Gun Battery) from 1954 to 1958. Lieutenant Colonel Faltyn retired from the Marine Corps reserve in 1966 and remained an active supporter of the Marine Corps. He served on the steering committee and helped establish the Marine Corps Coordinating Council of Greater Oregon in 1994. A devout and honorable man, Bert Faltyn died on 8 June 1994. The Marine Corps League Chapter in Salem is now named in his honor.

Fighting continued to be bitter and costly, but under the command of General Graves "Big E" Erskine, another Belleau Wood veteran and General Smith's former Chief of Staff, 3rd Marine Division overran Airfield \#2 and its commanding terrain, which was fanatically defended. It then broke through to the sea on 9 March 1945 and began flanking the final Japanese defenses to the north. It is believed that Kuribayashi committed suicide in his headquarters on 23 March 1945. By 26 March, all enemy opposition was reported eliminated.

The price of Iwo Jima was staggering: 6,821 Marines killed in action, with 25,851 wounded. Among these was Marine Private Howard Spencer Brandon, Jr., a Sioux Indian whose family was from Grande Ronde, Oregon. Brandon, an All Marine Boxer, was KIA on 9 March 1945 while serving with Co. D, 2/28, 5th MarDiv. He was 
shot by a sniper while carrying a wounded buddy back to an aid station. In addition to these Marine losses, 176 US Navy personnel were killed in action and 1,100 wounded. Almost every Japanese defender had been killed. Combat efficiency of the 3rd, 4th, and 5th Marine Divisions was estimated to be no more than 30\% ( $70 \%$ casualty rate). As General "Howlin Mad" Smith said: "This was the toughest fight." ${ }^{129}$ On Iwo Jima, 550 Marines were killed and 2,500 were wounded for every square mile of the island. This was as one US Navy Seabee officer stated: "The most expensive real estate the United States ever purchased. ${ }^{130}$ Of the 80 Medals of Honor given to Marines in World War II, 22 were earned on Iwo Jima (12 of them posthumously). Two additional Medals of Honor were earned from among the 738 dedicated Navy doctors and hospital corpsmen who struggled alongside their Marine comrades. But the conquest of Iwo Jima started paying dividends even as fighting was going on, for on 4 March 1945, the damaged B-29 "Dinah Might" made the first forced landing on Airfield \#1. By summer, an average of 20 damaged B-29's per day were thankful to be able to land on Iwo Jima. Graphically, the official Army Air Corps history stated that by the end of the war, 2,251 bombers carrying 24,761 American crewmen were saved because of Iwo Jima being available as a safe emergency airfield.

${ }^{129}$ Moskin, The US Marine Corps Story, p. 373.

${ }^{130}$ Colonel A. C. Zinni, Commander 9th Marine Regiment, to Author at Battlefield Study of Iwo Jima, January-February 1989. 


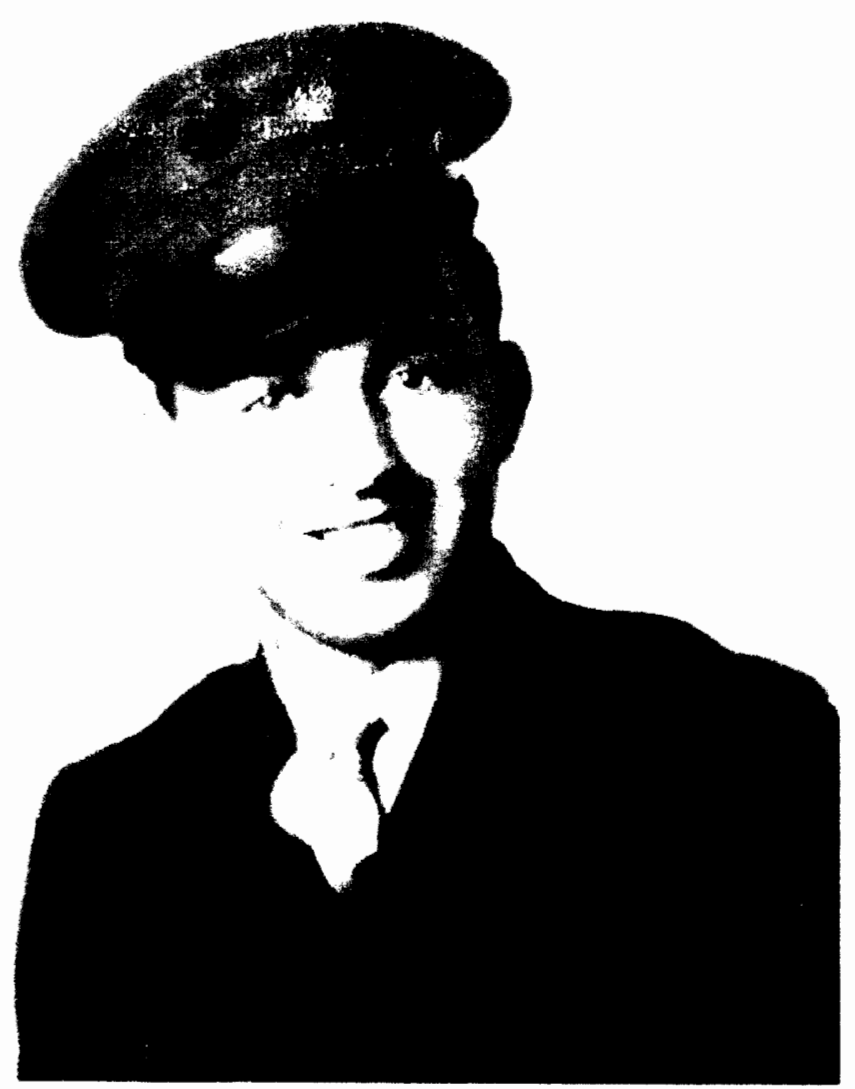

Figure 57: Howard Spencer "Stubby" Brandon Jr., a Sioux Indian of Grande Ronde, killed in action on Iwo Jima, 9 March 1945. His younger brother would later serve in Vietnam and make the Marine Corps a career.

Photo courtesy of P.E. "Gunny" Brandon Collection 
With the noose ever tightening around what remained of the Imperial Japanese Empire, America and her Allies prepared for the final stages of the war. The long United States advance from both the Central and Southwest Pacific was about to converge on one island.

Okinawa was to be the last and largest land battle of the Pacific War. The largest island in the Ryukyu chain, it was just 400 miles south of the Japanese mainland. At 794 square miles, Okinawa presented a considerable challenge due to its size and large population of 400,000 civilians. It was also well within range of Japanese airbases on mainland Kyushu.

American forces were under the overall command of Admiral Nimitz. Altogether, there were over 1,200 Navy vessels. The joint Army and Marine landing force was designated as the 10th Army, under the command of General Simon Bolivar Buckner Jr., US Army (son of the last surviving Confederate lieutenant general of the Civil War). The 10th Army consisted of the US Army XXIV Corps and the Marine III Amphibious Corps, under General Roy Geiger. The latter consisted of the 1st, 2nd, and 6th Marine Divisions (the other half of the Marine Corps was just beginning to rebuild following Iwo Jima). The plan was to land on the western Hagushi beaches and seize the Yontan and Kadena airfields to the east. The 1st and 6th Marine Divisions would land as the left (northern) flank, while the Army 7th and 96th Infantry Divisions covered the right (southern) flank of the landing beaches. The 2 nd Marine Division would make an amphibious feint off of the extreme southeastern shore. The 27 th and 77 th Infantry 


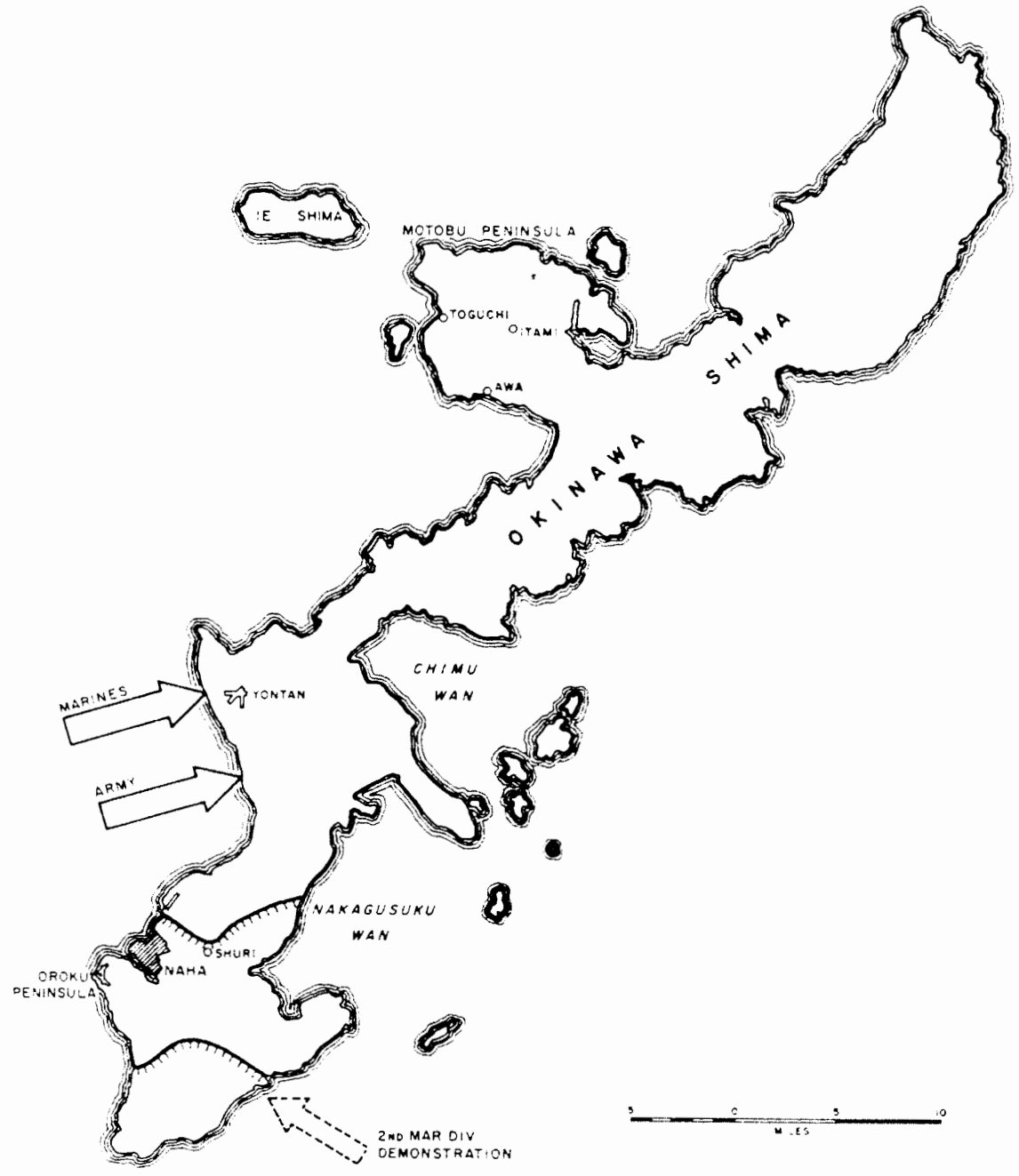

Battle for Okinawa, 1 April to 21 June 1945.

Figure 58 Map of Okinawa, Ryukyu Islands, April 1945

Soldiers of the Sea by Heinl. p. 493 
Divisions would follow in reserve. The Marines were to cut the island in half and turn north, while the Army would land and push south.

One Marine preparing to make the landing on Okinawa was Corporal Frank Wilford Kyser, of Milwaukie, Oregon. He had graduated from Union High School and joined the Marine Corps in Portland on 28 November 1942. Now serving as a forward observer with Company I, 3rd Battalion, 4th Marine Regiment of the newly formed 6th Marine Division, Kyser had made such landings before. He had originally served with the 3rd Raider Battalion, and had participated in the landing on Guam (24 July 1944). Kyser would land with his unit on 1 April 1945, and participate in the conquest of the northern half of Okinawa. On 21 May 1945, he would be wounded by shrapnel in the attack on Sugarloaf, just north of the Okinawan capital of Naha. This prominent hill had to be taken seven times by Marines (of the 22 nd \& 29th Regiments) before finally being held. Kyser's wounds were wrapped by a Navy corpsman and he continued with his unit. He would eventually be one of eight of the original 40 Marines of his platoon who had landed on Okinawa (32 of their fellow Marines were casualties evacuated during the battle).. ${ }^{131}$

Holding Okinawa against the American typhoon of steel, was General Mitsuru Ushijima and his 100,000 Japanese troops of the 32nd Army. Most of these were deployed in heavily fortified positions at the southern end of the island, near the capital

${ }^{131}$ Personal Interview between F. W. Kyser and author, Portland, Oregon, 7 October 1994. 
of Naha and the military headquarters beneath Shuri Castle (the center of the main Japanese defense line). Like Iwo Jima, Japanese tactics now focused on preserving defensive strength and forcing the Americans into a costly attrition warfare scenario involving a series of fortifications in depth. To meet the Americans on the beach in force would only invite rapid Japanese manpower destruction under vastly superior aerial and naval firepower. Ushijima would sit, wait, and play for time. He also knew that a new weapon from the mainland would be used against the American fleet: Japanese suicide planes known as Kamikazes.

On Easter Sunday, 1 April 1945, American forces hit the Okinawa beaches and moved rapidly ashore against light opposition. By nightfall, 50,000 troops were ashore in an area eight miles long and four miles deep. Two days later, the 1st Marine Division had successfully cut the island in half. At 1000 on the morning of 5 April 1945 Martin Albert Ludwig of Roseburg, while serving as a 30 calibre machine gunner with 3rd Battalion, 11th Marine Regiment, took a .25 caliber Japanese rifle slug in the chest, which exited his left hip. Ludwig was a veteran of both the Cape Gloucester and Peleliu campaigns where he had managed to avoid earning a Purple Heart. He survived on Okinawa, despite being paralyzed for two months from the waist down, was evacuated eventually to Camp Adair, Oregon, and was discharged as a corporal on 15 Jan 1946 from Mare Island, California. He returned home to become a mechanic and later join the 
1st Marine Division Association in Oregon. ${ }^{132}$ The 6th Marine Division on their left swung north and despite some heavy opposition on the northwestern Motobu Peninsula, 6th Marine Division secured the northern four-fifths of Okinawa by 20 April 1945.

It was during the latter phase that the 6th Engineer Battalion, later to become "Oregon's Marine Own" (located in Portland, Salem, and Eugene from 2 October 1971 to the present) began to distinguish itself in combat engineering. On 11 April 1945, 6th Engineer Battalion, under the command of Major Paul F. Sackett, had established its command post just north of Nago, where General Shepherd's headquarters for 6th Marine Division was located. Of the 6th Engineer Battalion line companies, Company A, was attached to the 4th Marine Regiment, Company B to the 22nd Marine Regiment, and Company $\mathrm{C}$ to the 29th Marine Regiment. To the west of Nago, the Japanese had attempted to destroy a 120 -foot concrete arch bridge, but it was still intact and strong enough to allow the lead assault battalion of infantry to cross, followed by a few supply trucks, ambulances, and even two bulldozers. But while in the process of being inspected for methods of repair, it suddenly collapsed. This caused quite a dilemma as Marines were engaged with the enemy on the enemy side of the bridge with no way of being supplied, reinforced, or having wounded evacuated. The Bailey bridge, which was once referred to as "that glorious, precision made, British built bridge which is the envy

${ }^{132}$ Personal Interview between M. A. Ludwig and author, Portland, Oregon, 4 October 1993. 

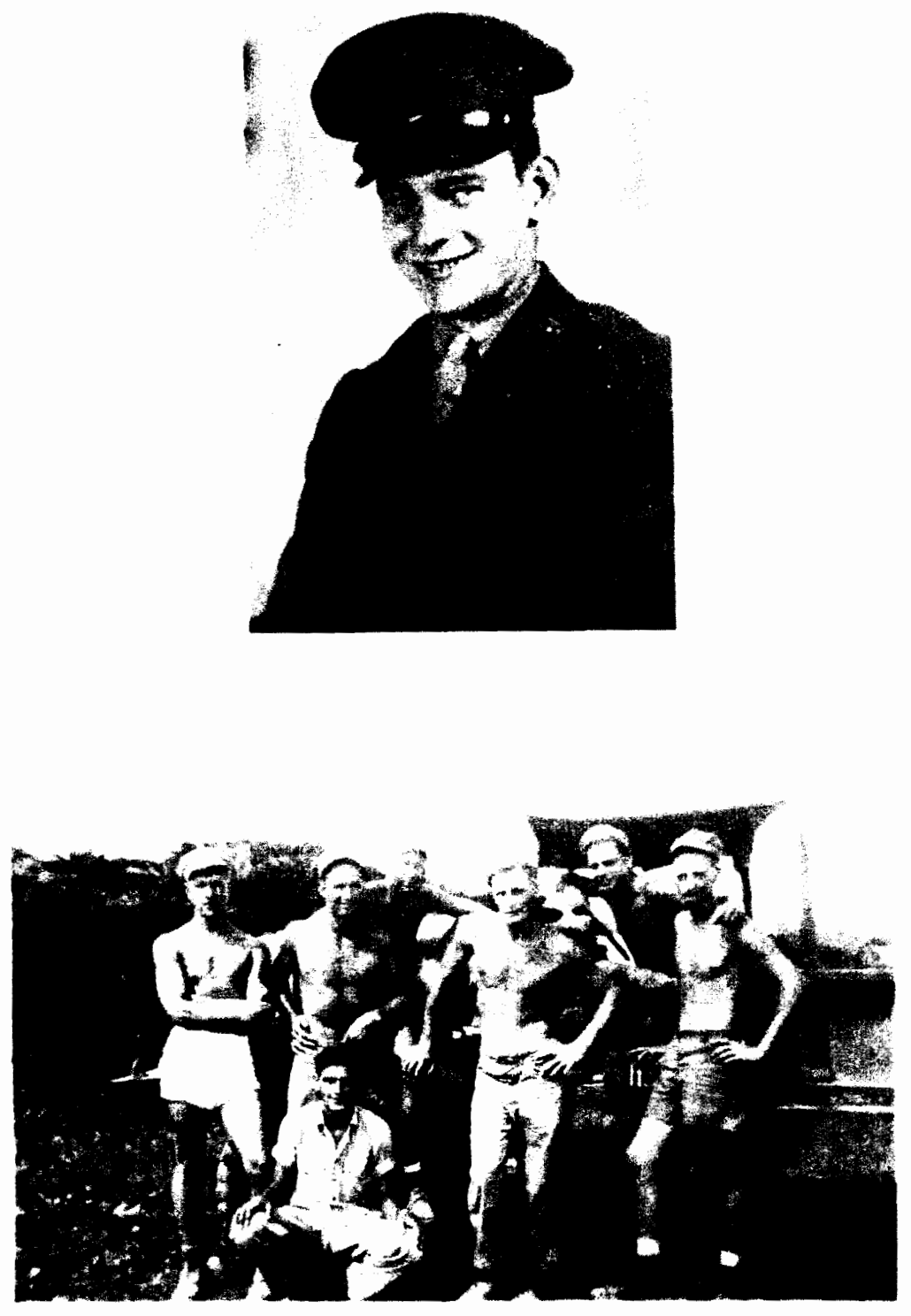

Figure 59: Martin A. Ludwig of Roseburg, 1942.

Figure 60: Martin A. Ludwig with Marine buddies from 3rd Battalion, Il th Marine Artillery Regiment, 1st Marine Division, on Okinawa, just prior to being wounded in action 5 April 1945.

Photos courtesy of Martin A. Ludwig Collection 
of the civilized world, "133 had only recently been adopted by the Marine Corps and 6th Engineer Battalion had not yet received one. A Bailey was quickly obtained from an Army depot and erected, despite the lack of experience and the difficulty in launching due to the difficult terrain. The actual 130 -foot bridge was completed by the next morning and duly christened as tanks crossed to support the advance. This bridge west of Nago was the first Bailey erected by Marines in combat, and a tribute to the initiative, innovativeness, and ingenuity of 6th Engineer Battalion. ${ }^{134}$

The Marines of the 6th Engineer Battalion continued throughout the Okinawa campaign to provide all engineer support to 6th Marine Division. This consisted of the following (often accomplished under enemy fire): clearing mines in front of advancing tank and infantry columns, constructing a total of 25 bridges, combat trail and road construction, airfield construction and repair, water purification, electrical support, bulk fuel support, and general construction support. As Major Sackett, the battalion commander, later stated:

"The Okinawan campaign was unusual in several respects. It involved an amphibious landing, a war of movement, wherein the division advanced daily for considerable distances, and it involved frontal assaults on prepared positions protected by water barriers and well-placed minefields. This battalion met and solved all problems as they arose and

${ }^{133}$ Cornelius Ryan, A Bridge Too Far, New York, 1974, Son Bridge film scene with Michael Caine, p. 258.

${ }^{134}$ Robert S. Mayo, With the Marines on Okinawa, Lancaster, Pennsylvania, 1946/1976, p. 9-10. 
demonstrated that its engineers are flexible enough to meet any kind of warfare." 135

Meanwhile, on the southern end of Okinawa, the US Army had run into serious problems. Having turned south upon the initial landing, it had met increasingly stronger resistance until 11 April 1945, when it was stopped cold at the main Japanese defense line. With the 7 th and 96th Infantry Divisions stalled, the Army brought in the 27th Infantry Division to regain momentum southward. But in 12 days of heavy fighting, only a two-mile gain was achieved. The 1st and 6th Marine Divisions were now brought in to reinforce the Army by forming the right (western) wing. The 77th Infantry Division, which had previously taken the Kerama and Ie Shima Islands off of Okinawa, was also brought in. Six American divisions were now formed up across the southern fifth of Okinawa, along the main Japanese defense line. On 4-5 May 1945, General Ushijima either made a mistake or lost control of his subordinate commanders. The Japanese launched a large counterattack against the US Army divisions, which was disastrous in that American aerial, naval, and artillery firepower simply obliterated large numbers of crack Japanese troops out in the open. Over 6,227 were killed, weakening their defenses. By 11 May 1945, under torrential rains, and in grim, grueling warfare, the Americans pushed slowly southward through the main defenses. On 26 May 1945, the 6th Marine Division stormed into Naha, turning the Japanese western flank. On 29 May 1945, the 1st Marine Division crushed the center of Ushijima's defenses at Shuri Castle (unlike Iwo

${ }^{135}$ P. F. Sackett, 6th Engineer Bn., After Action Report, Battle for Okinawa, Japan, 21 June 1945. 


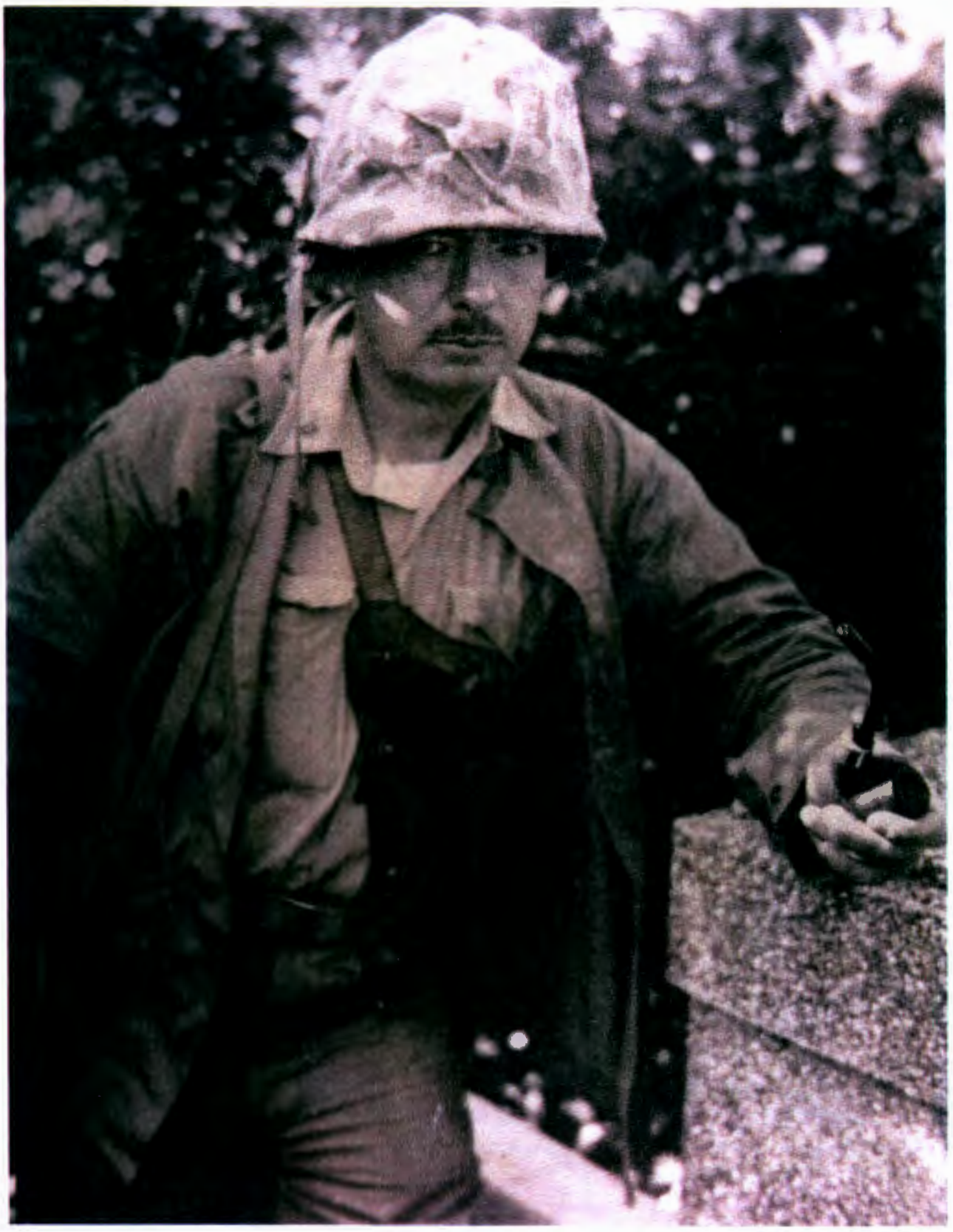

Figure 61: Robert S. Mayo, 6th Engineer Battalion executive officer and historian, Okinawa, 1945.

Photo courtesy of Mrs. Ruth Mayo Collection 

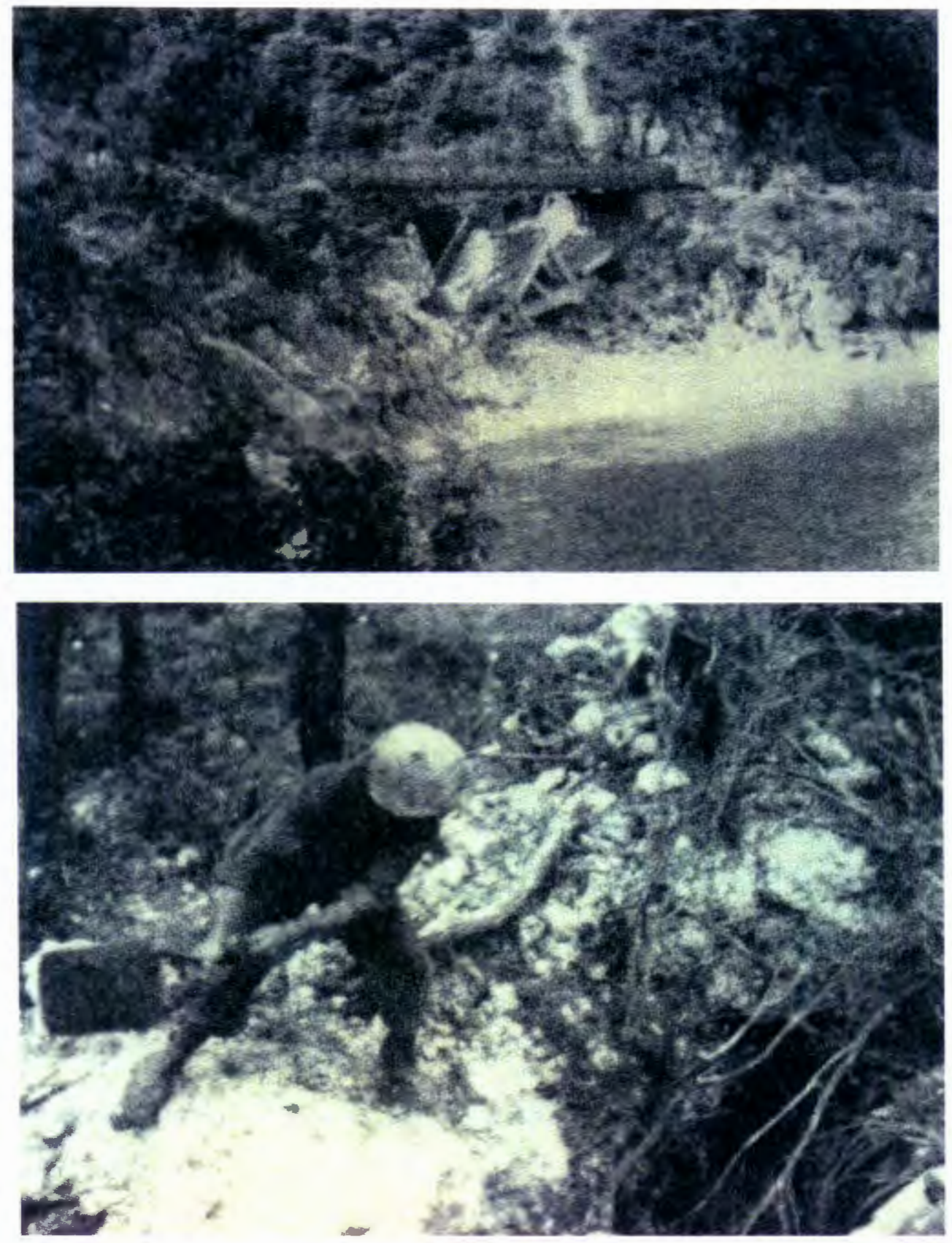

Figure 62: Blown Japanese bridge just west of Nago, Okinawa. 6th Engineer Battalion erects first Bailey Bridge in Marine Corps history so as to allow the continued advance of 6th Marine Division.

Figure 63: Marine combat engineer hurling satchel charge into Japanese defensive position on Okinawa.

Okinawa Victory in the Pacific, Marine Corps Historical Branch, 1955, p. 91 and 225. 
Jima, the first "American" flag to go up over Shuri was the Confederate flag of a young southern Marine officer). Army progress was slow but steady in the east.

In an isolated area of the Battle for Okinawa, one Portlander was affected in a manner which would touch many future generations of schoolchildren in Oregon. Private First Class James Blair Faubion Jr., was born in Portland on 24 September 1926, and joined the Marine Corps shortly after graduation from Grant High School at the age of 17. His father, James B. Faubion Sr., had served as a Marine in France during World War I, while his mother had also served in France as an Army nurse. He was president of his student body, was active in civic theater and was head of the Junior Red Cross. Upon completion of Boot Camp in San Diego, California, he was assigned to 1st Marine Division (which was rebuilding following Peleliu) in October 1944. Faubion landed across the Hagushi Beaches of Okinawa that clear Easter Sunday morning of 1 April 1945. In June, he was severely wounded when he was shot in the back by a Japanese sniper. He was evacuated and underwent surgery in which he lost both legs and was paralyzed in the waist. Returning to Portland, where he was discharged from the Marine Corps on 18 January 1947, he refused to be treated as "another invalid" and actively fought to lead a productive life. He returned to civic theater for several productions and turned to writing radio scripts. Despite his indomitable will to live, Jim Faubion, at the age of 22 , died as a result of his war wounds on 12 June 1949 . In memory of his "courageous spirit, radiant personality, cheerful disposition, and inspiration to all who knew him," and citing this action as "a daily reminder to the youth of our nation that 
great heroes exist in peace and war," the Portland Public School system in 1950, named the Faubion School in northeast Portland after him. ${ }^{136}$

On 4 June 1945, the 6th Marine Division made its second amphibious landing on Okinawa when it withdrew and landed on the Oroku Peninsula in the southwest. With additional support from 2nd Marine Division, Japanese defenses began to rapidly collapse, despite savage fighting by individual units. It was during this last main thrust to the southern tip of Okinawa, that the senior ground commander, General Simon Bolivar Buckner, Jr., US Army, was killed by Japanese artillery fire on 18 June 1945. Command was assumed by Major General Roy Stanley Geiger, the first Marine General to command an American field army. He was soon promoted to Lieutenant General of Tenth Army. By 22 June 1945, the Battle for Okinawa was over.

The Japanese 32nd Army was wiped out with more than 100,000 killed, and 10,000 wounded and captured. The civilian population of Okinawa paid a horrible price with over 100,000 (a quarter of their population) also being killed. American losses were also heavy: Marines suffered 3,440 killed and 15,487 wounded; Army with 4,675 killed and 18,099 wounded; and Navy with 4,907 killed and 4,824 wounded (kamikazes accounted for 36 ships sunk and 368 damaged). Japanese airpower virtually disappeared with 7,800 aircraft being destroyed.

${ }^{136}$ Resolution by Superintendent of Schools, James B. Faubion Primary School, (Portland, Oregon, 8 December 1949) and Eugene E. Snyder, Portland Names and Neighborhoods: Their Historic Origins, (Portland, Oregon, 1979), p. 237. 
Six weeks following the Battle for Okinawa, Japan surrendered unconditionally on 15 August 1945. American nuclear capability had precluded the planned invasion of the Japanese mainland. On 30 August 1945, Corporal Frank W. Kyser of Milwaukie, Oregon, landed with his unit for occupation duty at Yokosuka, Japan. Under the terms of surrender, all Japanese gun emplacements were to be clearly marked by white flags. Kyser and his fellow Marines couldn't help but notice the hundreds of white flags around the area where they landed. These Marines were thankful that America had the bomb and used it. ${ }^{137}$

On 2 September 1945, in Tokyo Bay, Lieutenant General Geiger stood aboard the USS Missouri as the Japanese surrender document was signed. Not only did he represent the 522,777 men and women (37,664 officers and 485,113 enlisted men) of the United States Marine Corps, ${ }^{138}$ but he stood for an unbroken series of victories in many desperate battles across the Pacific. He also represented 80 Medal of Honor winners and 86,940 United States Marine casualties.

${ }^{137}$ Personal Interview between F. W. Kyser and author, 7 October 1994.

${ }^{138} \mathrm{Heinl}$, Soldiers of the Sea, p. 611. 


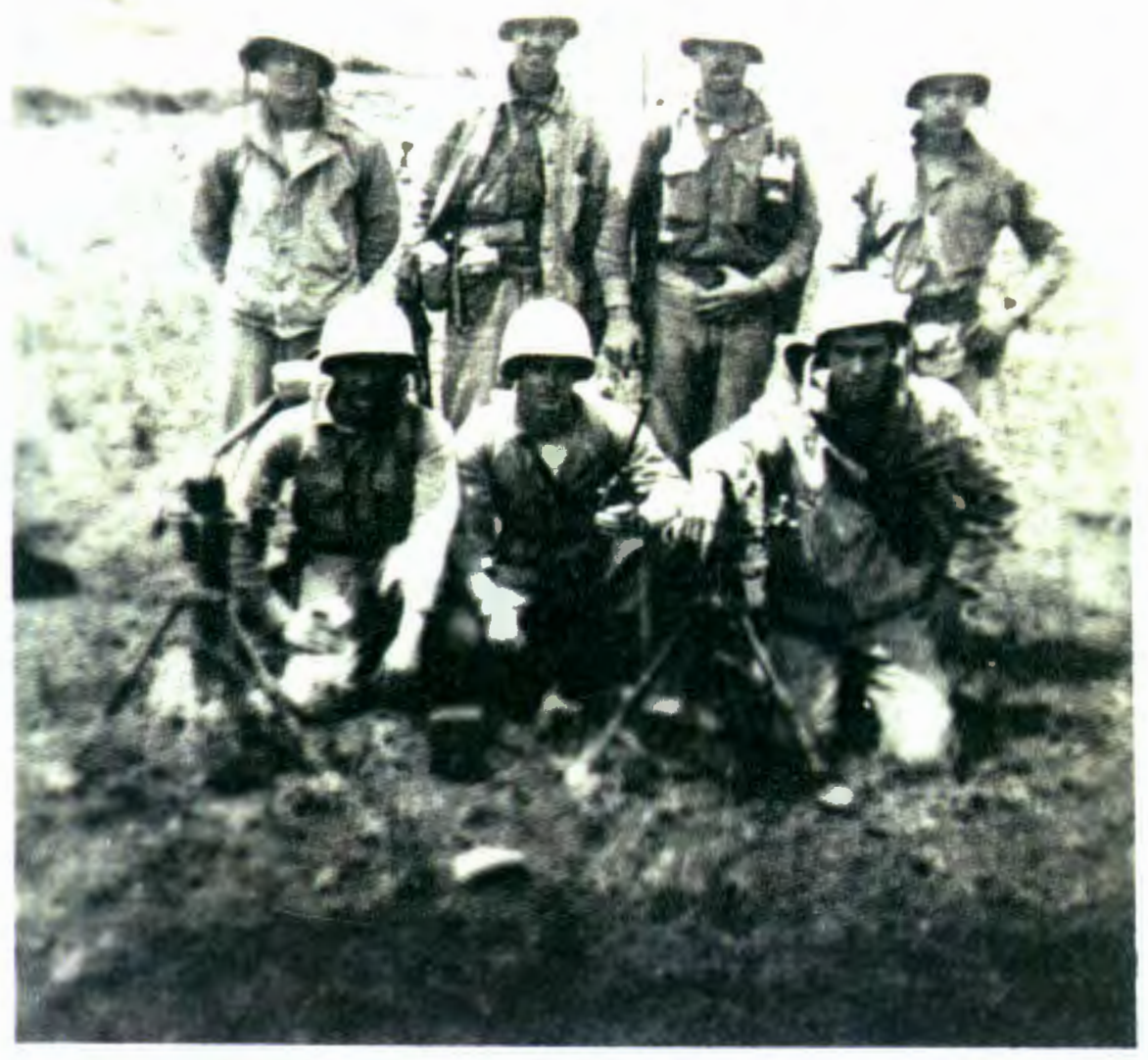

Figure 64: Frank W. Kyser, of Milwaukie with the remaining 7 members of his mortar platoon (of the original 40), Company I, 3rd Battalion, 4th Marine Regiment, 6th Marine Division, Okinawa, June 1945. Kyser earned a Purple Heart on Okinawa and would later also survive the Chosin Reservoir of Korea.

Photo courtesy of Erank W. Kyser Collection 


\section{CHAPTER VI}

\section{KOREA, THE CHOSIN FEW, COLD WAR}

"The bended knee is not a tradition of our Corps. "139
A. A. Vandegrift: To the Senate Naval Affairs Committee, 5 May 1946 (regarding US Army proposals to abolish USMC)

"I have just returned from visiting the Marines at the front, and there is not a finer fighting organization in the world. "140

Douglas MacArthur: In the outskirts of Seoul, Korea 21 September 1950

"In the vast complex of the Department of Defense, the Marine Corps plays a lonely role. "III

John Nicholas Brown: To the Senate Armed Forces Committee, 17 April 1951

${ }^{139} \mathrm{Heinl}$, Dictionary of Military and Naval Quotations, p. 184.

${ }^{140}$ Ibid., p. 184.

${ }^{141}$ Ibid., 184. 
When President Roosevelt died in 1945, the Marine Corps lost a true friend and enthusiastic supporter (the president's son had served as a Marine raider officer throughout the Pacific conflict). Roosevelt's pride in the Corps had never wavered. Others were equally appreciative. On the beach at Iwo Jima, Secretary of the Navy James Forrestal (in unmarked Marine combat utilities) had stated as the flag went up on Suribachi, that the Marine Corps had earned its future for the next 500 years. But within fifteen months, the very existence of the Corps was being questioned in the nation's capital

The primary postwar challenge which faced the Marine Corps was to demobilize, restructure, and downsize as directed by Congress, an organization of 522,777 . On the eve of the Korean War, Marine strength had dropped to 85,864 , or an overall $85 \%$ reduction. The question of how to organize and select the right people for a stated mission was a difficult one, especially in light of ill-defined defense and foreign policies.

Although the Corps enjoyed high public prestige, the years 1946 to 1949 focused on a searching examination into the mission, and even the need for the Marine Corps. In January 1946, the US Army Collins Plan and Senate Bill S. 2044 (defense unification legislation), were proposed. On 6 May 1946, General Vandegrift appeared before the Senate Naval Affairs Committee and stated that this defense unification legislation would in all probability spell extinction for the Marine Corps. Under the first phase of this Army and Air Force plan, the Marine Corps was to be reduced to no combat unit larger than a regiment, the Marine Corps Reserve was to be abolished, and all Marine air assets 
would be incorporated into the Air Force. As it had on five other occasions in Marine Corps history since 1829 , Congress and the American people rallied to the cause of preserving the Marine Corps. Though S.2044 was defeated, this was but a reprieve, for in January 1947, another similar bill reducing the Marine Corps to a nonentity was sent to Congress. This time, the Joint Chiefs of Staff prohibited the Commandant or any other active duty Marine from testifying before Congress against it. With the iron firmness and calm which had won him the Medal of Honor with his 1st Raider Battalion at Guadalcanal, General Merritt A. Edson submitted his request for immediate retirement and headed for Capital Hill. Edson, in vigorous and effective testimony, rallied congressional and public opinion to the Marine Corps. The National Security Act of 1947, in which a strongly sympathetic Congress included a charter for the Marine Corps, helped to resolve many of these Marine Corps mission's issues. Primary among these was to giving the Marine Corps a firm mission focused on amphibious operations, and assigned to the Corps another mission stemming back to 1798: "such other duties as the President may direct." Readiness would thus continue to be the Marine watchword that America could depend upon. This importance of the Marine Corps as an essential team member of the United States military establishment was further clarified in 1952, when the Douglas-Mansfield Bill afforded the Commandant of the Marine Corps coequal status on the Joint Chiefs of Staff.

In April of 1947, the Marine Corps Reserve returned to Oregon. Captain Harold C. Montgomery, who had earned a Bronze Star on Iwo Jima, was assigned on 23 April 


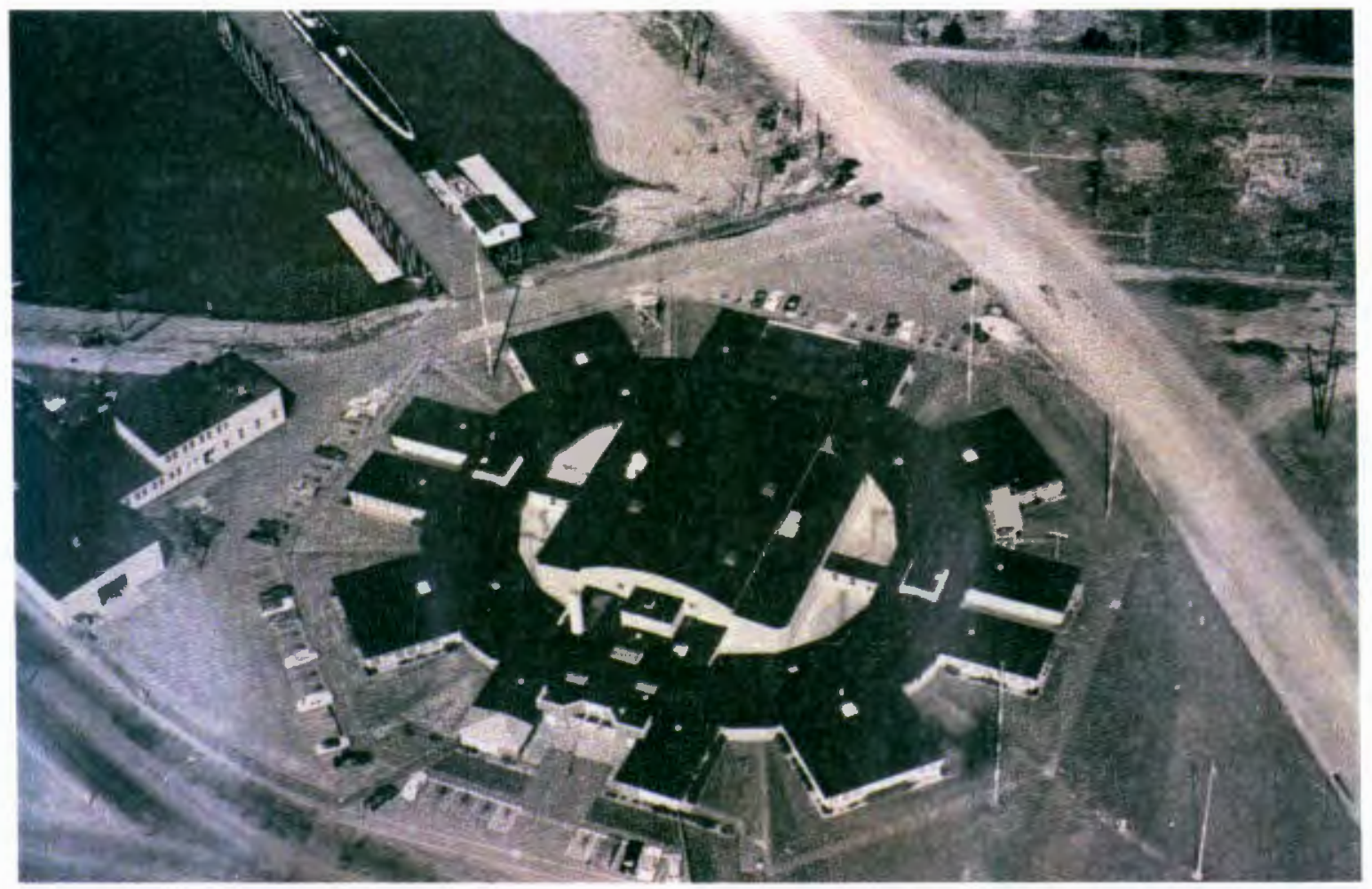

Figure 65: Marine Corps Reserve Training Center, Portland, 1947, home of 4th 105 Howitzer Battalion and 17th Engineer Company. This was formerly the World War II Kaiser Shipbuilding headquarters at Swan Island.

Photo courtesy of Navy Reserve Training Center. Portland Collection 
1947, by the Commandant of the Marine Corps, General A. A Vandegrift, to be Inspector-Instructor (active duty advisor) of the reestablished reserve unit in Portland. Here, the 4th 105 Howitzer Battalion, under the command of Major Douglas Polivka, was formed on Swan Island, in what used to be the Kaiser Shipbuilding Headquarters. It was comprised of Headquarters Battery and Battery A. In addition to 4th 105 Howitzer Battalion, the first of a long line of Portland Marine reserve engineer units was formed in June of 1947. This was the 17th Engineer Company, under the command of Major George A. Smith. Together these units represented well over 200 drilling Marine reservists, who met from 1900 to 2100 hours every Tuesday night. In Eugene, Battery B, 4th 105 Howitzer Battalion was formed, while in Salem, Battery C, 4th 105 Howitzer Battalion was established. Both Eugene and Salem consisted of approximately 100 Marines each, for a total 4th 105 Howitzer Battalion strength in Oregon of about 400 marines. The 17th Engineer Company consisted of approximately 100 Marines. These units spent two weeks of each of the next three summers conducting their annual training at either Camp Pendleton or the Marine Corps Air Ground Training Center at 29 Palms, California.

On 24 June 1950, the 127,000 man North Korean army, spearheaded by armor, crossed the 38th parallel and plunged into South Korea. Within three days, the capital of Seoul had fallen, and the North Koreans continued to press southward. President Truman ordered General MacArthur, under the auspices of the United Nations, to send help. This consisted of US Army troops of the 24th Infantry Division, from Japan, which 


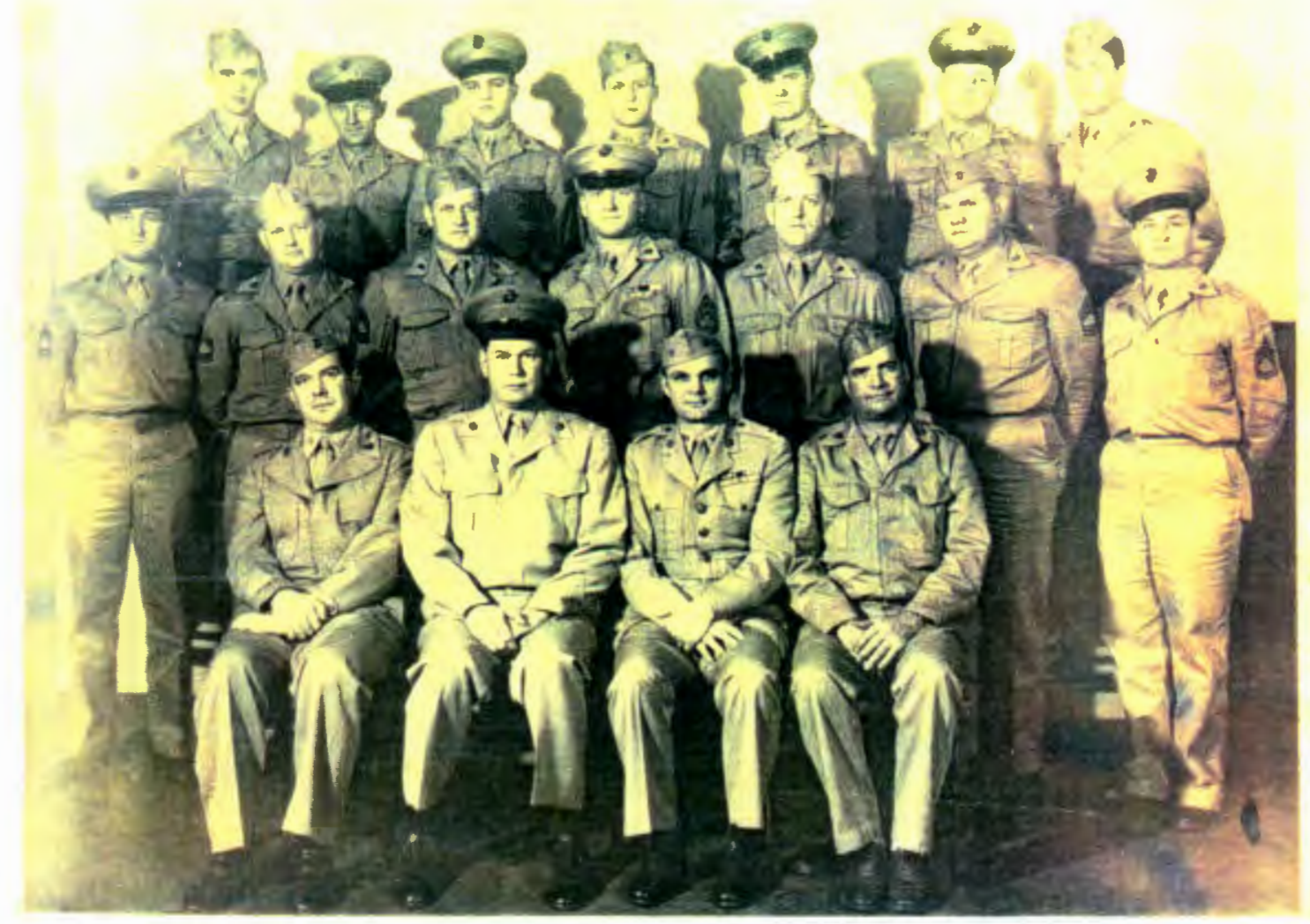

Figure 66: 4th 105 Howitzer Battalion and 17th Engineer Company Reserve and Inspector-Instructor staffs, Portland, 1947.

Photo courtesy of Lucille Montgomery Collection 

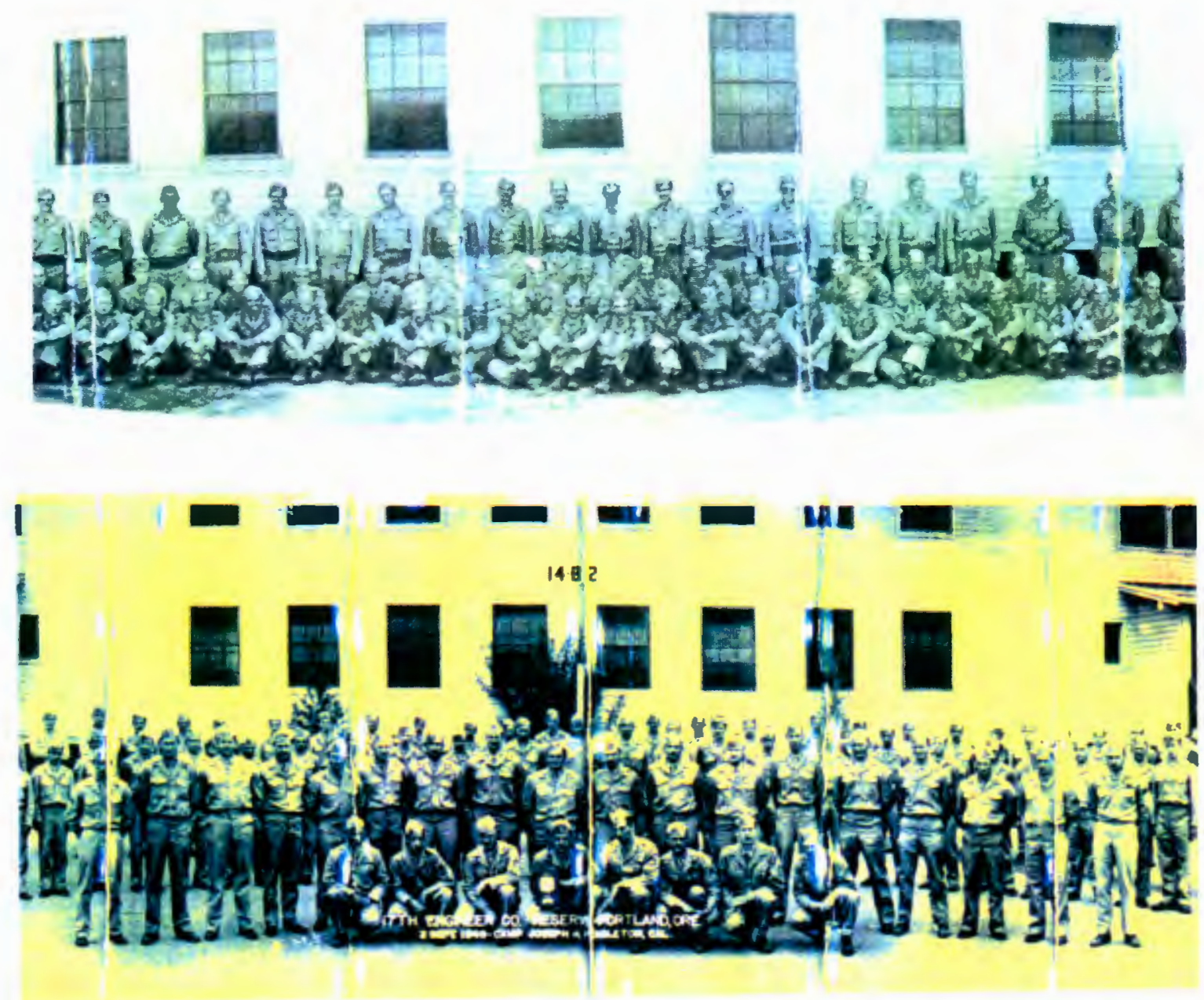

Figure 67 and 68: 17th Engineer Company Marines of Portland, at Camp Pendleton, California during their annual training periods of summer 1948 and 1949. Many of these engineers would later serve in Korea with 1st Engineer Battalion, 1st Marine Division.

Photos courtesy of Richard $\underline{R}$ Bautch Collection 


\section{Sletch of Nacal Reserte Armory Earmartiod for Salem}

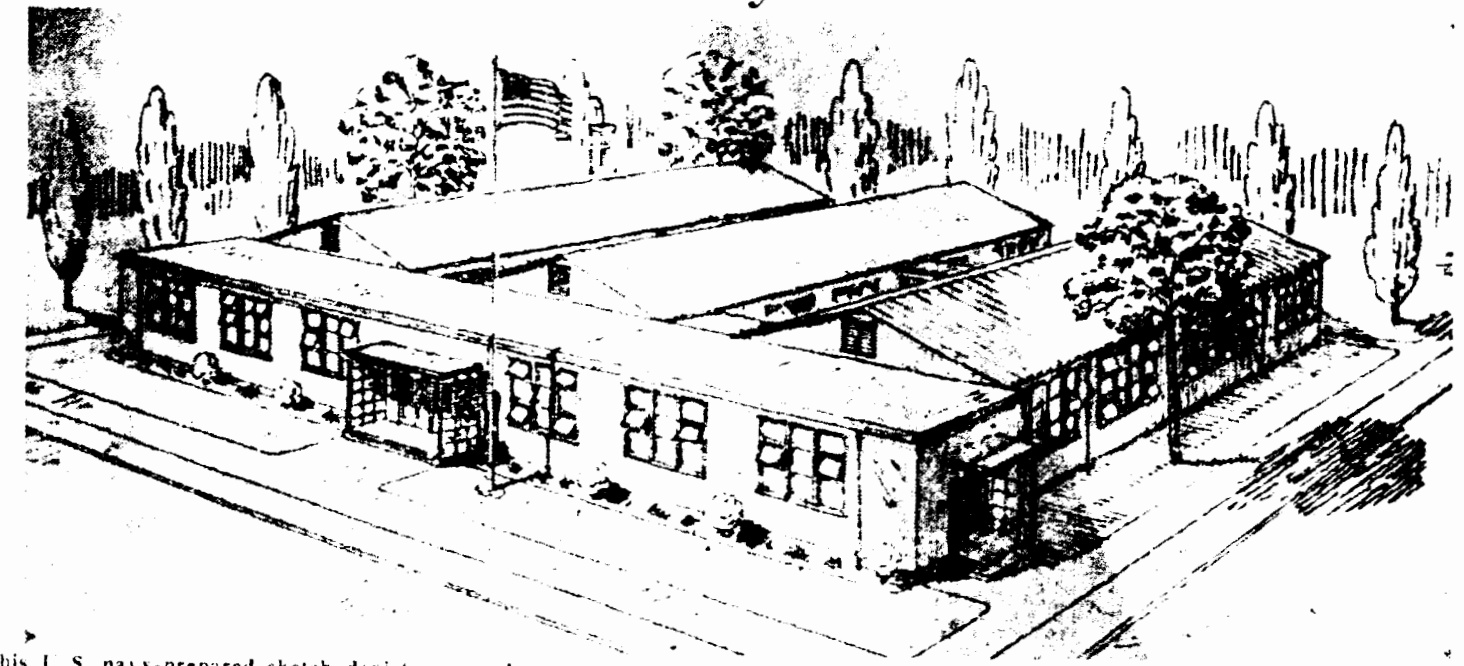

This 1 . S. natb-prepared sketch degicts a nasal reserve armury of the 13 pe to be constructed in satem. local reserve ofticials aid larger. whth the forward connecting bailding be of this dexign but ind used for aceombiy and moster purpesen. Three

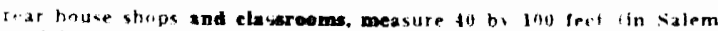

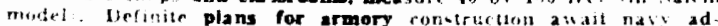
Fertisement for bidk and averdins of contract. but supplies airesds are berinning to arrive. Mftelak ald some 200 chains are experted In a shipment this weenend.

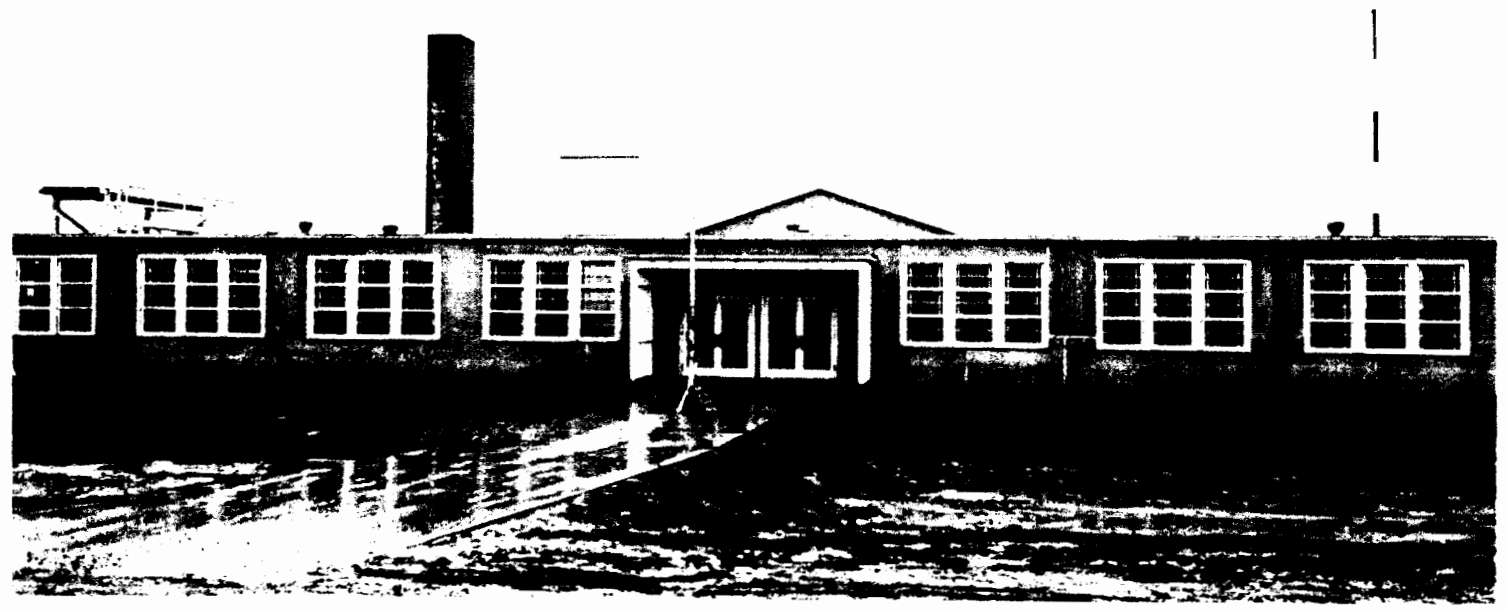

Figure 69 and 70 Initial 1948 drawing of Salem Reserve Center, followed by 26 July 1949 photo of actual facility.

Photo courtesy of Salem Marines' Command Historical Summary File 


\section{C"BATTERY 4TH 105MM HOWITER BATTALION}

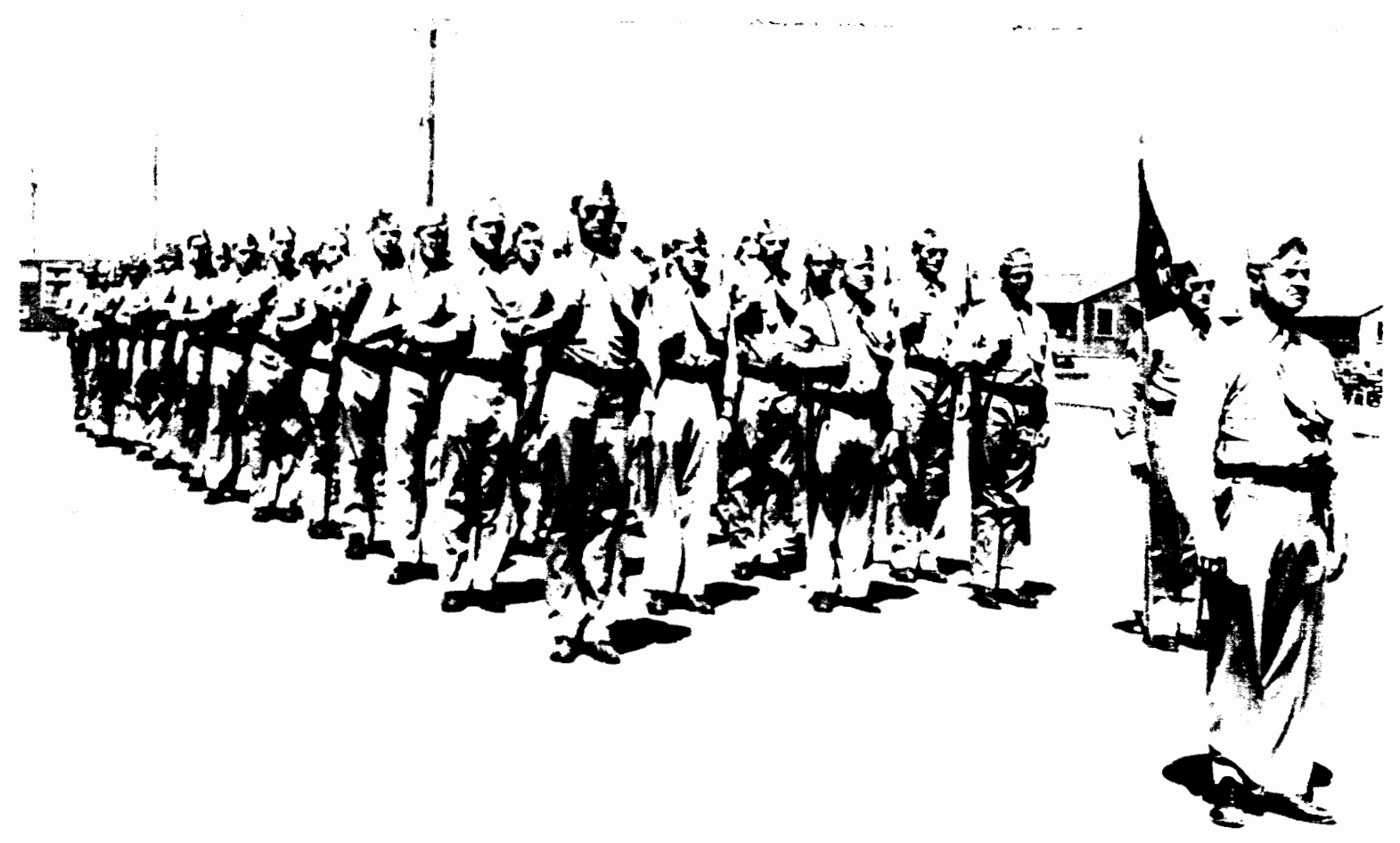

Figure 71. First Salem Marine reserve unit of Battery $C$, th 105 Howitzer Battalion, commanded by Major Leonard G Hicks 2nd Lieutenant Hubert J Faltyn ( Navy Cross winner on Iwo Jima) is officer in second row. extreme left He would later command the Salem Marines following the Korean War

Photo courtesy of Salem Marines' Command Historical Summary File 


\section{Salem Marine Reservists Off to Camp}

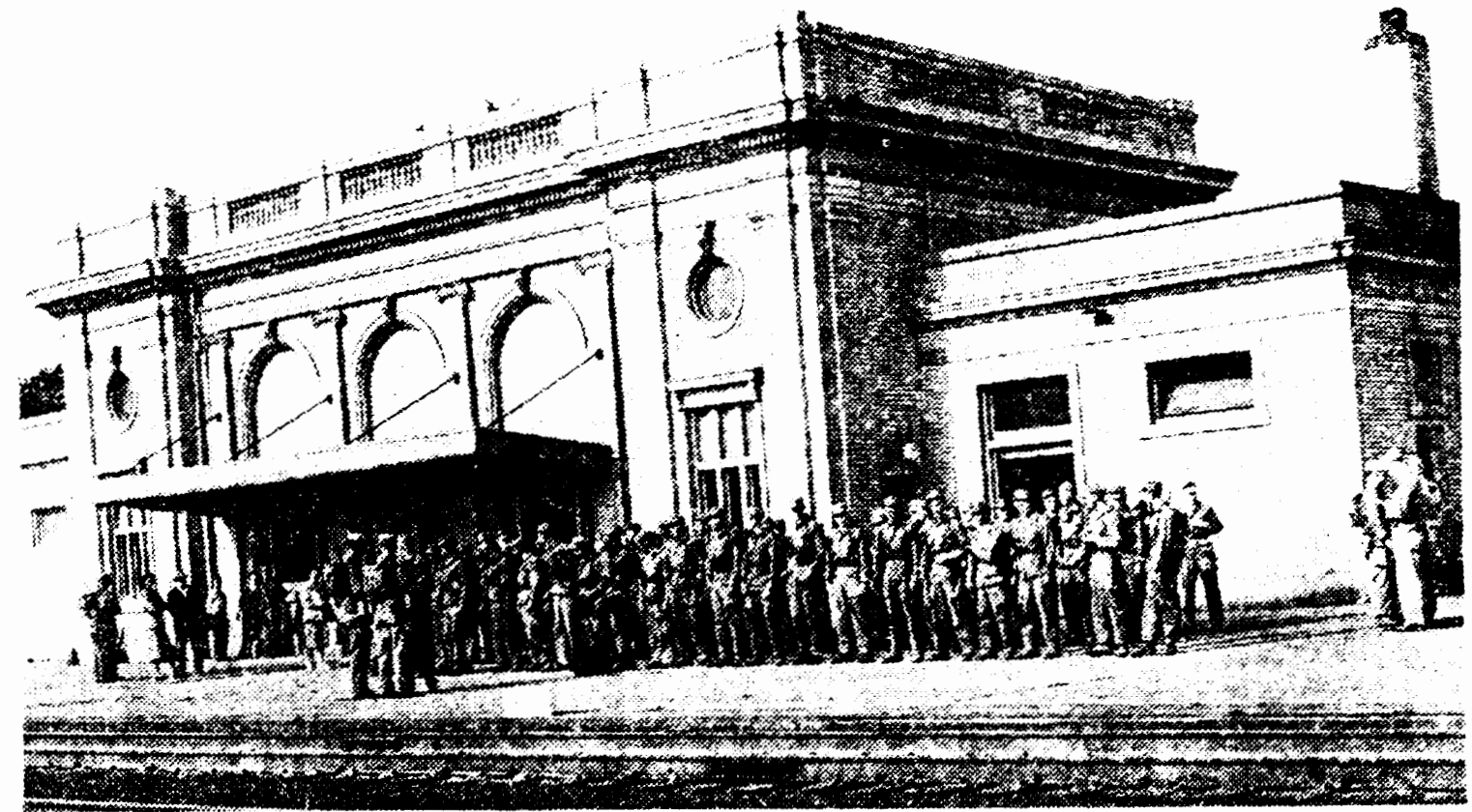

These members of $\mathrm{C}$ battery, 4th $105 \mathrm{~mm}$. howltzer battalion, Salem unit of the marine corps reserve, will begin their two-weeks training period at Camp Pendleton, Calif., today, having arrived at the USMC base vesterday. The unit Is shown above at the Salem railroad station early Saturday morning just before it boarded a special 22-car train for the trip to camp. Their activities this week vill be reperted bo Don Dill, Statesman staff photographer and writer.

Figure 72: Salem Marine unit awaiting rail transportation to Camp Pendleton, late 1940's. For summer training periods, a train first picked up the Portland Marines, proceeded to Salem, and then headed to Eugene to embark those Marines. Use of commercial air transport replaced this system in the 1950's.

Photo courtesy of Salem Marines' Command Historical Summary File 

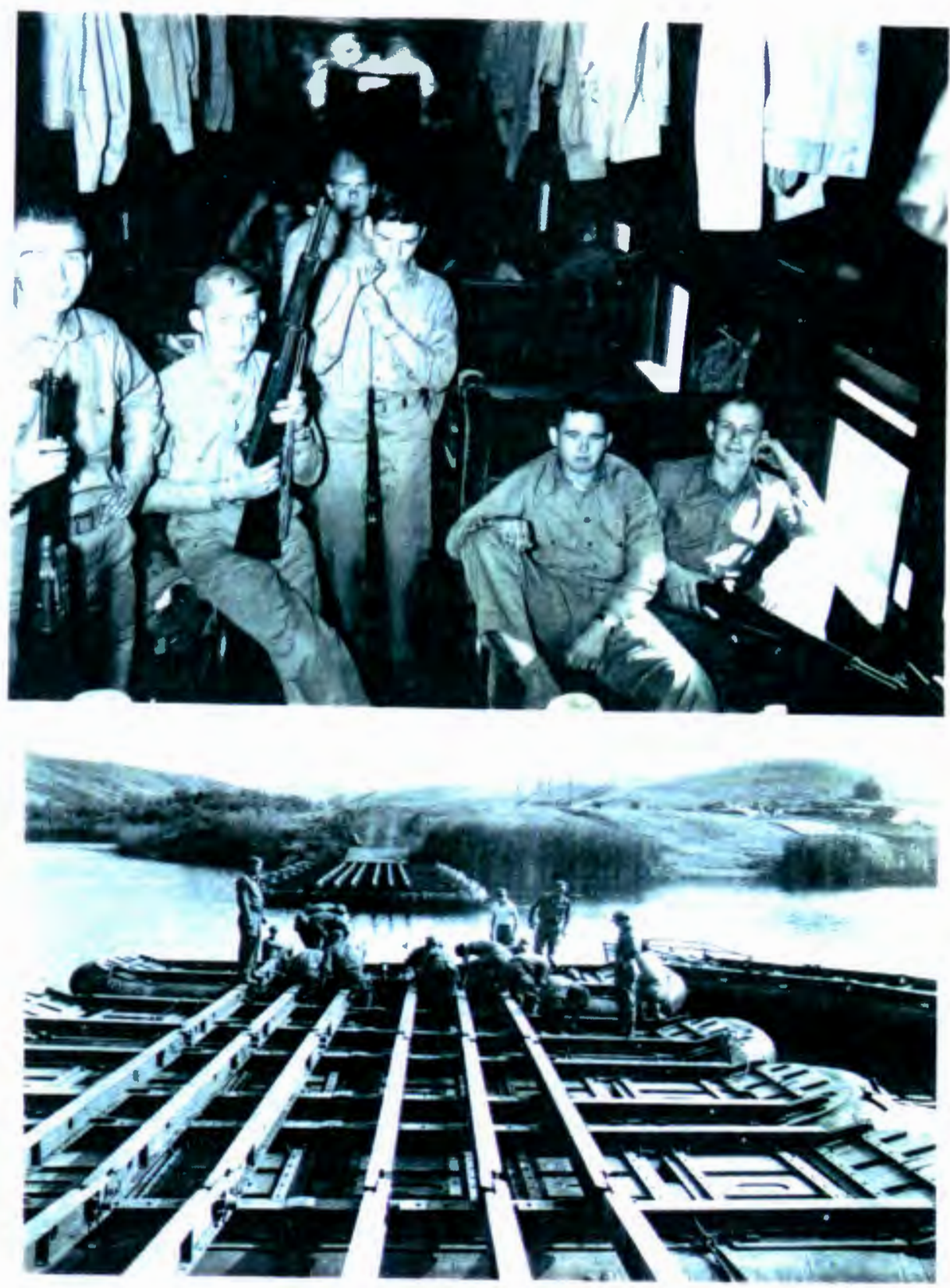

Figure 73: Oregon Marines on train bound for Camp Pendleton annual training period, late 1940 's.

Figure 74: Portland Marines of 17th Engineer Company erecting pontoon bridge at Camp Pendleton, late 1940's.

Photo courtesy of Richard R. Bautch Collection 

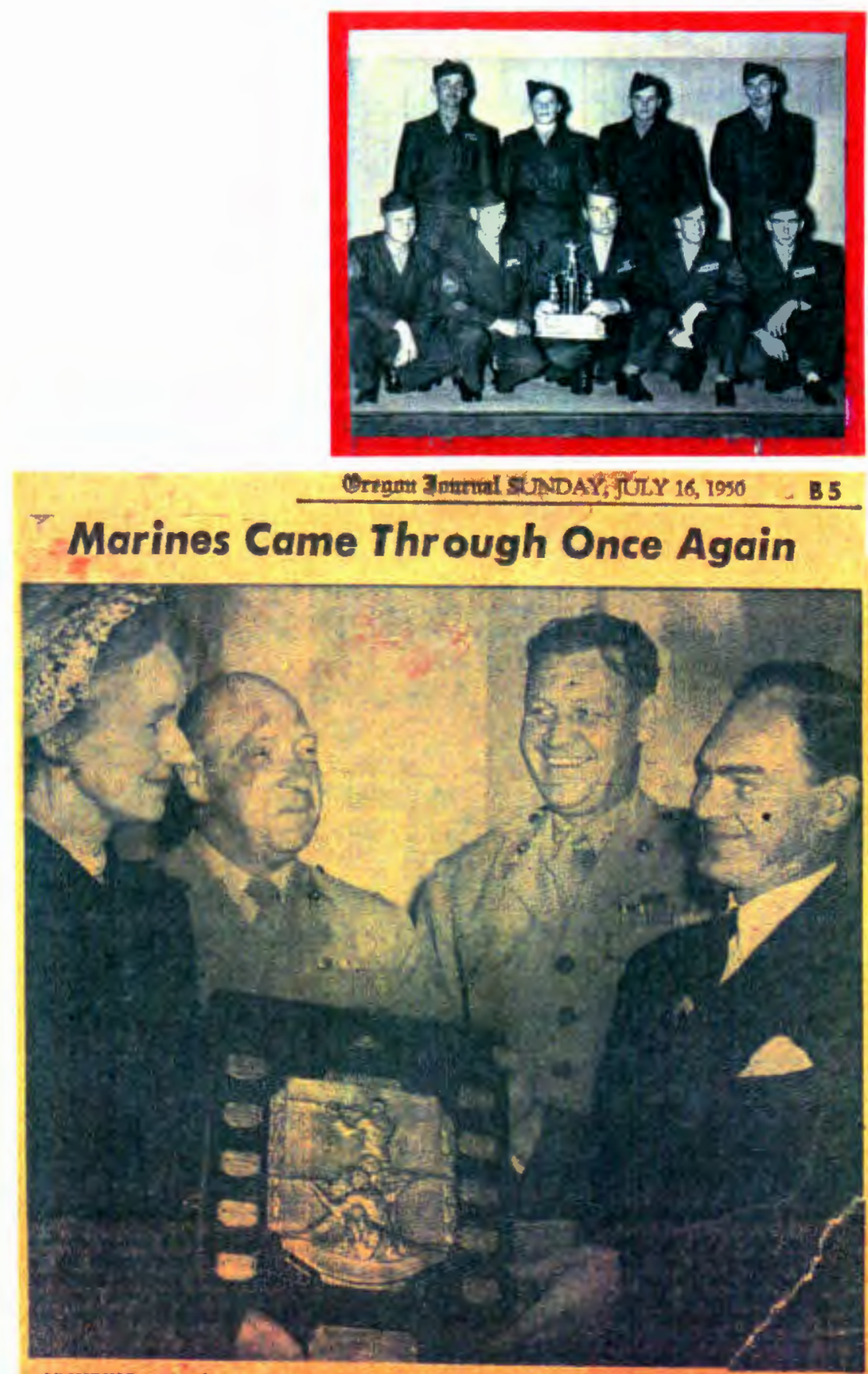

\section{Corps Gunners Nalion's BesI}

i Fhaver of the national chameloably in a recond-brealing port foriamee-that's the $17 \mathrm{ch}$ en

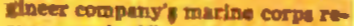
serwi cract rifle temso.

The martos rifle squad, whowe bese is at 5 wan Island, recentls rveorded the Whest score, .053 out of posibile 1000, ever shat by a reserve team. The undefeate ed Firemen, captulned bs lat IC. 7. 5 . Smith, recnried match competitian to eapture nitennt houprs.

Capt. I, C MeForrin of the 17 th sivision said that this fo the lirst time any unit ax amall is a eompeny has won the antonal tule. Thore were 84 other teams. competiag in the content.

Col. W. O. Thoingtom, directar of the 13 th marine corp restry diptrict, presented Mus. Georn A. Sthith, commmath of fleer of the 12ts engineer rompapy. with three totards: The Nattonal Rine eham. 3. anship trophy, and the west 19)ent and 2 ath district rth. 19t gaes fin plect trophiet.

10 Members of the feam are, cap

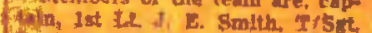

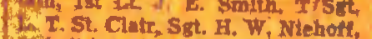
Q1. I. A Kontri, Ple. C L

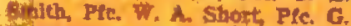
19. Stockton and Put it, J, Cama theth.

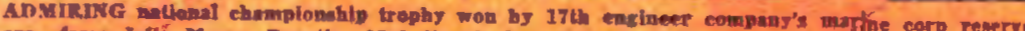

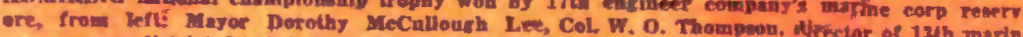

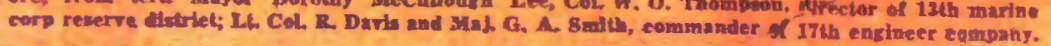

Figure 75: Portland Marines of 17th Engineer Company set the standard in rifle marksmanship, 1950.

Photo courtesy of Harry $\underline{H}$.W. Niehoff Collection 
did little to stem the tide of North Korean armor. The US Army was forced into a series of costly delaying actions as they retreated southeastward toward the main port of Pusan. Even the commander of the 24th Infantry Division was wounded and captured.

When North Korean forces invaded South Korea, the Marine Corps had a ground combat structure of two understrength divisions consisting of one regiment each. Just eight months before, the Chairman of the Joint Chiefs of Staff, General Omar Bradley, had predicted publicly that the world would never again see a large scale amphibious landing. The Marine Corps now faced another major war with but two understrength divisions, the 1st Marine Division at Camp Pendleton, California, and the 2nd Marine Division at Camp Lejeune, North Carolina. Marine aviation consisted of 11 understrength squadrons divided into two wings, one at El Toro, California, the other at Cherry Point, North Carolina.

On 2 July 1950, General MacArthur sent his first request to the Joint Chiefs of Staff for help from the Marines: a regimental combat team, plus a supporting Marine air group. South Korea was faced with mounting catastrophe. In the days that followed, MacArthur sent five more pleas culminating in a request for one war-strength Marine division and air wing. It was obvious that an 85,000 -man peacetime Marine Corps would not suffice, and ten days after the 1st Marine Provisional Marine Brigade sailed for Korea on 14 July 1950, President Truman activated the additional 138 units consisting of 33,528 Marines of the Organized Marine Reserve. 

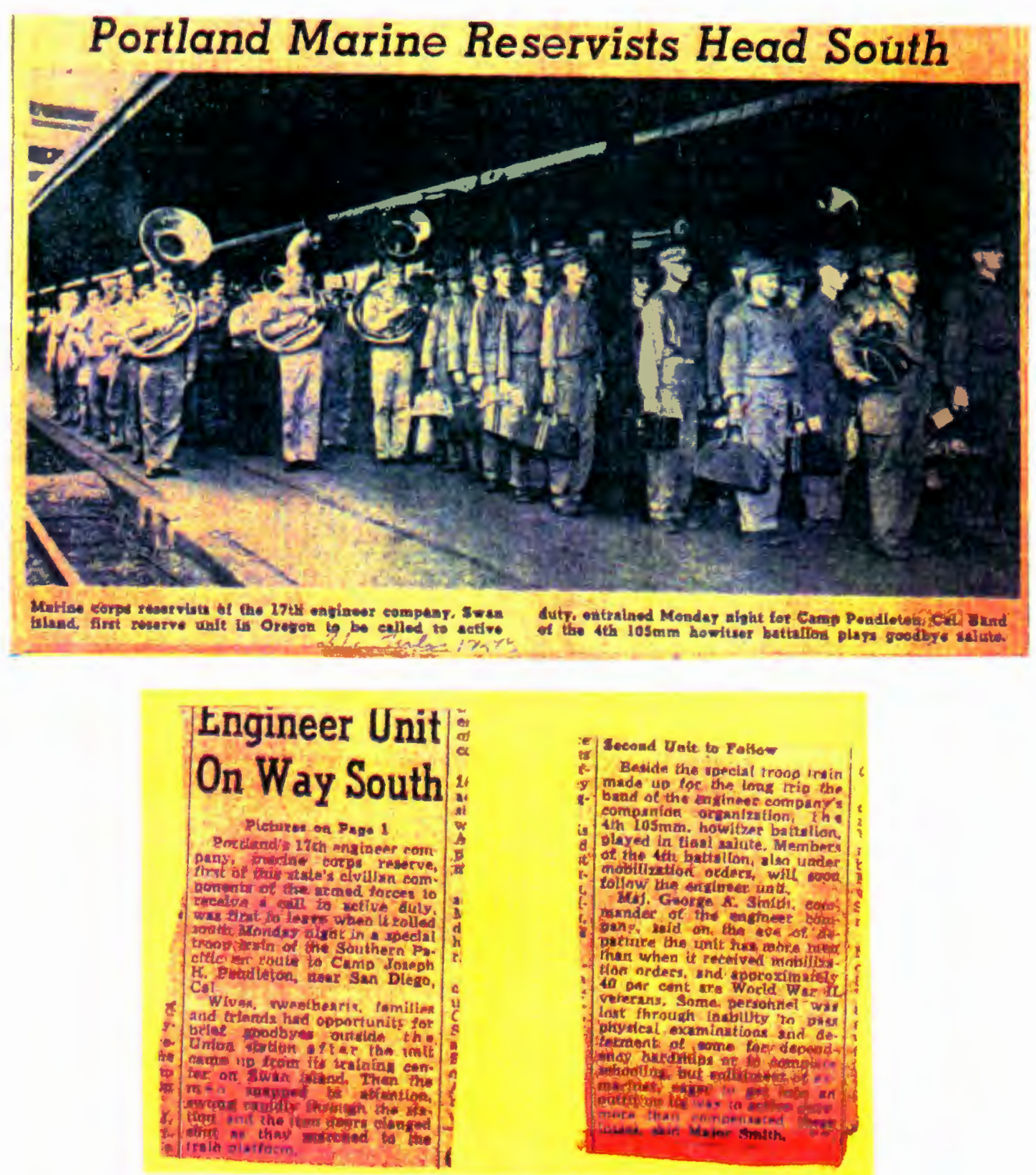

Figure 76: Portland Marines of 17th Engineer Company were activated for the Korean War on 29 July 1950. 4th 105 Howitzer Battalion followed on 8 August 1950 . Destination for both units: 1st Marine Division and Korea.

Courtesy of Oregon Chapter of Chosin Eew Collection 
On 29 July 1950, the Korean War came to Oregon when the 17th Engineer Company, still under the command of Major Smith, was activated and sent to Camp Pendleton. On 8 August 1950, the rest of Oregon's Marines were included when the entire 4th 105 Howitzer Battalion, now under the command of Major Roland Davis, was activated. A Marine troop train left Portland, stopped in Salem, and then in Eugene, before proceeding to Camp Pendleton with over 400 Oregon Marines. Upon processing in California, many of the 17th Engineer Company were assigned to the 1st Engineer Battalion, while most of 4th 105 Howitzer Battalion were augmented to the 3rd Battalion, 11th Marine Artillery Regiment.

On 3 August 1950, the 1st Marine Provisional Brigade debarked at Pusan, where it soon played a key role in being the "reaction force" within the Pusan perimeter. By 7 August 1950, eight years to the day after the landing at Guadalcanal, and 32 years since Belleau Wood, the 5th Marine Regiment (the ground combat element of the brigade) was again thrown in to turn the enemy tide. A British liaison officer watched them and reported to his headquarters in Tokyo:

"I am heartened that the Marine Brigade will move against the Naktong salient tomorrow. They are faced with impossible odds ... but these Marines have the swagger, confidence, and hardness that must have been in Stonewall Jackson's army. They remind me of the Coldstreams at Dunkerque." ${ }^{142}$

Perhaps the best tribute was by Hanson Baldwin's short sentence in the New

${ }^{142}$ Ibid, p. 542. 
York Times: "The Marines were ready." ${ }^{143}$

Meanwhile, back on 10 July 1950, in a private conference with General Shepherd (Commanding General Fleet Marine Force, Pacific), General MacArthur had pointed the stem of his corncob pipe at the port of Inchon and said:

"If I only had the 1st Marine Division under my command again (during the World War II New Britain campaign), I would land them here and cut the North Korean armies attacking the Pusan perimeter from their logistic support and cause their withdrawal and annihilation."

General Shepherd's response was: "Why don't you ask for the 1st Marine Division, General?" MacArthur shot back: "Do you think I can get it?"144

General Shepherd stated that, if approved by the Joint Chiefs of Staff in Washington, D.C., the Marine Corps would have 1st Marine Division ready by 1 September 1950. Augmented and reinforced by reserves from across the country, and by the 6th Marine Regiment of the 2nd Marine Division at Camp Lejeune, the 1st Marine Division was soon on its way to Korea. As the critical part of General MacArthur's plan to relieve Allied forces within the Pusan perimeter, the 1st Marine division was called upon to launch a major amphibious landing behind enemy lines. On 15 September 1950 , 1st Marine Division, under the command of General Oliver P. Smith, stormed the beaches at Inchon and immediately pushed eastward for Seoul. From his flagship, MacArthur sent this generous dispatch: "The Navy and Marines have never shone more

${ }^{143}$ Ibid., p. 544.

${ }^{144}$ Ibid., p. 539. 
brightly than this morning." ${ }^{145}$ North Korean resistance was crushed, and on 28 September 1950, the South Korean capital was in the hands of 1 st Marine Division.

One of those Marines landing at Inchon was Captain Robert P. Wray, who was born 21 September 1921, in Corvallis, Oregon. Commissioned a second lieutenant in the Marine Corps Reserve in June 1943, he had served in World War II as a flight instructor and later with Marine Night Fighter Squadron 542 in Yokosuka, Japan. In 1947, he received his regular commission, and following Amphibious Warfare School and service in China with Company C, 3rd Marine Regiment, he was designated as an infantry officer. Reestablished with the outbreak of the Korean War, he became the new commanding officer of Company $\mathrm{C}$, 1st Marine Regiment, 1 st Marine Division. He and his unit landed at Inchon and participated in the capture of Seoul. On 27 September 1950, Captain Wray earned the Bronze Star Medal when he voluntarily exposed himself to intense enemy fire in directing the attack of his company, supported by a platoon of tanks, against an enemy battalion reinforced with antitank guns, holding a town. Assaulting over 3,000 yards, the enemy position was taken and over 200 North Koreans were killed. He remained in command of Company $\mathrm{C}$ through the Chosin Reservoir campaign, and the Chinese counteroffensive in the spring of 1951. On 24 February 1951, Captain Wray earned his first Silver Star Medal, when he personally led a tank-infantry force through heavy enemy mortar, machine gun and small arms fire, across the Amul River into the town of Hoengsong. When his lead element was temporarily halted by

\footnotetext{
${ }^{145}$ Ibid, p. 551.
} 
withering fire from several houses, he moved forward across an open rice paddy to encourage his men to close with the enemy. This they did, resulting in the recovery of five captive friendly soldiers and the killing of an estimated 50 enemies. On 23-24 April, Captain Wray earned his second Silver Star when the right flank platoon of his company was overrun on a high hill by Chinese in a series of desperate night attacks. He repeatedly exposed himself to machine gun, mortar, and small arms fire to reestablish his defensive line. Throughout the remainder of the night, he continued to move under heavy fire from position to position, encouraging and directing his Marines, and evacuating the wounded. In this, he was later cited for his "inspiring leadership, exceptional courage and unswerving devotion to the fulfillment of his mission." Captain Wray returned to the United States in May 1951. Following a full career in the Marine Corps, which included Chief of Staff of 3rd Marine Division, in Vietnam, from 1969 to 1970, Colonel Wray retired in June 1973, as the Commanding Officer, Naval ROTC and Professor of Naval Science at Oregon State University. He is now a municipal judge in Junction City, Oregon. Of his 31 years, his most cherished Marine Corps memory is having served with Marine Lieutenant General Lewis Burwell "Chesty" Puller, when the latter was commanding officer of the 1st Marine Regiment in Korea. Colonel Wray is quick to confirm that not only was "Chesty" Puller (who rose from the rank of corporal) the Corps' most decorated Marine, but also its most colorful.

Largely as a result of the readiness and amphibious capability of the Marine Corps, the North Korean army south of the 38th parallel had been all but cut off. North 
Korea suffered 8 divisions destroyed. 1st Marine Division now linked up with the advancing 8th Army (which had broken out of the Pusan perimeter 16 September 1950). South Korean and United Nations forces now crossed into North Korea, with the strategic sequel to the Marine triumph of Seoul and Inchon being another amphibious flanking maneuver at Wonsan, on the east coast of North Korea.

By the winter of 1950 , the North Korean capital had fallen and United Nations forces approached the Yalu River, which divided North Korea from China. Spread out and in short supply, these United Nations forces were caught off guard when on 1 November 1950, Chinese Communist "volunteer" Forces of 750,000 men attacked south across the Yalu.

The Marine Corps saga of the Chosin Reservoir is remarkable, and is most often referred to proudly by the nickname of its veterans: the "Frozen Chosin." On 27 November 1950, lead elements of the 1st Marine Division had advanced over 78 miles to the northwest of the port of Hungnam, North Korea to the vicinity of the Chosin Reservoir. The temperature was 32 degrees below zero. Here, 5th and 7th Marine Regiments encountered at the town of Yudam-Ni, stiff Chinese resistance which increasingly grew. The 1st Marine Division had been assigned a 300 mile long by 50 mile wide zone of action from Wonsan to the Yalu. To advance or withdraw within this area, there was but one precipitous mountain road, upon which the Marines were deployed in column by regiment. When South Korean and US Army units on both of its flanks crumbled under the Chinese onslaught, the 1st Marine Division, in the dead of winter, 
was surrounded by 10 Chinese divisions. At Yudam-Ni, on the west side of the Chosin Reservoir, were 5th and 7th Marine Regiments, with the 11 th Marine Artillery Regiment in direct support behind them at Hagaru-Ri, at the sound end of the Chosin. Between Hagaru-Ri and Koto-Ri, where Colonel "Chesty" Puller's 1st Marine Regiment was in reserve, the Chinese cut the main road on 28 November 1950. General O. P. Smith called upon Royal Marine Lieutenant Colonel Douglas B. Drysdale and his 14 officers and 221 Royal Marines of 41 Independent Commando (who were serving again in combat with American Marines against the same enemy as in the 1900 Boxer Rebellion). Reinforcing the Royal Marines with Company G, 3rd Battalion, 1st Marine Regiment, 29 tanks from Companies B \& D, 1st Tank Battalion, an Army infantry company, and a convoy of 141 trucks, they were given orders to break through to the north to reinforce Hagaru-Ri. "Task Force Drysdale" moved north from Koto-Ri on 29 November 1950, the same day that General Smith ordered 5th and 7th Marine Regiments to move south from Yudam-Ni back to his location at Hagaru-Ri. Drysdale though wounded, broke through the Chinese lines, at a heavy cost of 141 trucks, of 922 men, 162 were KIA and 159 WIA. 75 were lost. One of those Marines with Task Force Drysdale was Private First Class Otto N. Olson of Astoria, who was serving as a Browning Automatic Rifleman (BAR) with Company G, 3rd Battalion, 1st Marine Regiment. Olson would survive Korea and return home to become a forester for the State of Oregon. ${ }^{146}$ ${ }^{146}$ Personal Interview between O. N. Olson and author, Portland, Oregon, 2
October 1994. ${ }^{146}$ Personal Interview between O. N. Olson and author, Portland, Oregon, 2 
These were desperate times as three US Army Infantry battalions of the 7 th Infantry Division disintegrated on the east side of the Chosin. Both Marine flanks were now exposed. Veteran Chinese General Sung Shih-lun massed his forces and issued the clear and simple order: "Destroy the Marine Division as you would a snake in your home." Overconfident, the Chinese chose to batter themselves against the one American division in Korea which was properly concentrated, ready, and prepared to both take and dish out the worst.

Meanwhile, Marines at the small unit level continued to do their job. Sergeant Eldon Earl Gould was born in Corbett, Oregon, on 11 April 1927. As a former member of the Portland Marines 17th Engineer Company, he now served with Company B, 1st Engineer Battalion, 1st Marine Division, as a heavy equipment detachment squad leader. With him at the Chosin were two International-Harvester TD-18 bulldozers, several trucks, and a dozen Marine operators, mechanics, and combat engineers with demolitions. Their mission was to improve (strengthen and widen) the narrow road up through the rocky passes to the Chosin Reservoir. Their main challenge was widening curves some four miles south of Koto-Ri, in which they used Composition 2 plastic explosive, military dynamite, TNT, and captured Chinese pitric acid to blast the rock hillsides. They also dug gun positions, pushed disabled vehicles and equipment from the road, and helped build, with the rest of 1 st Engineer Battalion, two airstrips. These were at Hagaru-Ri and Koto-Ri, and were used for resupply and wounded evacuation flights. At the Chosin, Sergeant Gould lost four of his-Marines to Chinese machine gun and rifle 


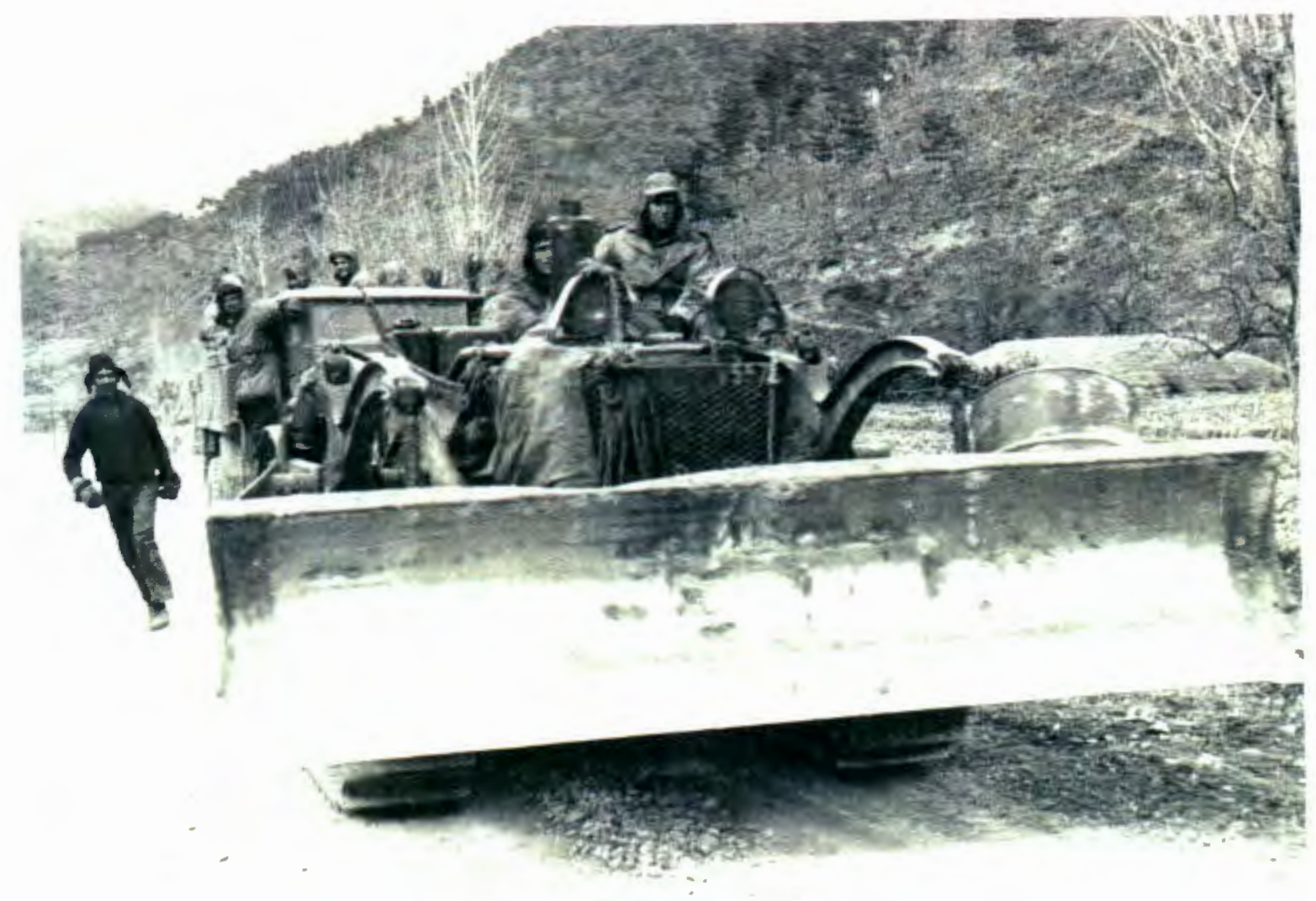

Figure 77: Oregon Marines, formerly of 17th Engineer Company, Portland, now serving with 1st Engineer Battalion, 1st Marine Division in Korea. Bulldozer is vintage World War II International Harvester TD- 18. Inchon and Seoul were behind these Marines in the fall of 1950, but the brutal Chosin Reservoir campaign lay ahead.

Photo courtesy of Oregon Chapter of Chosin Few Collection 
fire. Following the return over the difficult terrain from the Chosin to the port of Hungnam, he now states that USMC stands for: "Uncle Sam's Mountain Climbers."147 Indicative of the intense and close quarter fighting which took place in the breakout from the Chosin Reservoir, is the story of Battery H, 3rd Battalion, 11th Marine Artillery Regiment. This $105 \mathrm{~mm}$ towed howitzer battery of six guns was in the thick of the action at Chosin, and of approximately 100 Marines, it consisted of at least a dozen Oregonians. Corporal Richard A. Jackson, of Portland, was attached out to the infantry as a forward observer radioman to Company E and Company F, 2nd Battalion, 7th Marine Regiment, during the advance up to Hagaru-Ri, and was then attached to Company I, 3rd Battalion, 7th Marine Regiment during the fight back to the coast. His job was to call in artillery fire for the infantry units to which he was attached. These usually consisted of WP (white phosphorous) for adjustment, followed by mostly HE (high explosive) with some VT (variating time for air bursts), with almost all targets being large bodies of Chinese troops in the open. Though canister (shotgun type rounds) would have come in handy on 27-30 November 1950, when over 1,000 Chinese infantry were killed at close range while attempting to overrun Battery $\mathrm{H}$, none was in the ammunition allotment at the time. High explosive shells did the job and rounds were normally not expended on groups of less than eight enemy. Small arms fire was used on those Chinese that got closer. Very little counter-battery fire was done as most incoming

\footnotetext{
${ }^{147}$ Personal Interview between E. E. Gould and author, Portland, Oregon, 2
} December 1993. 

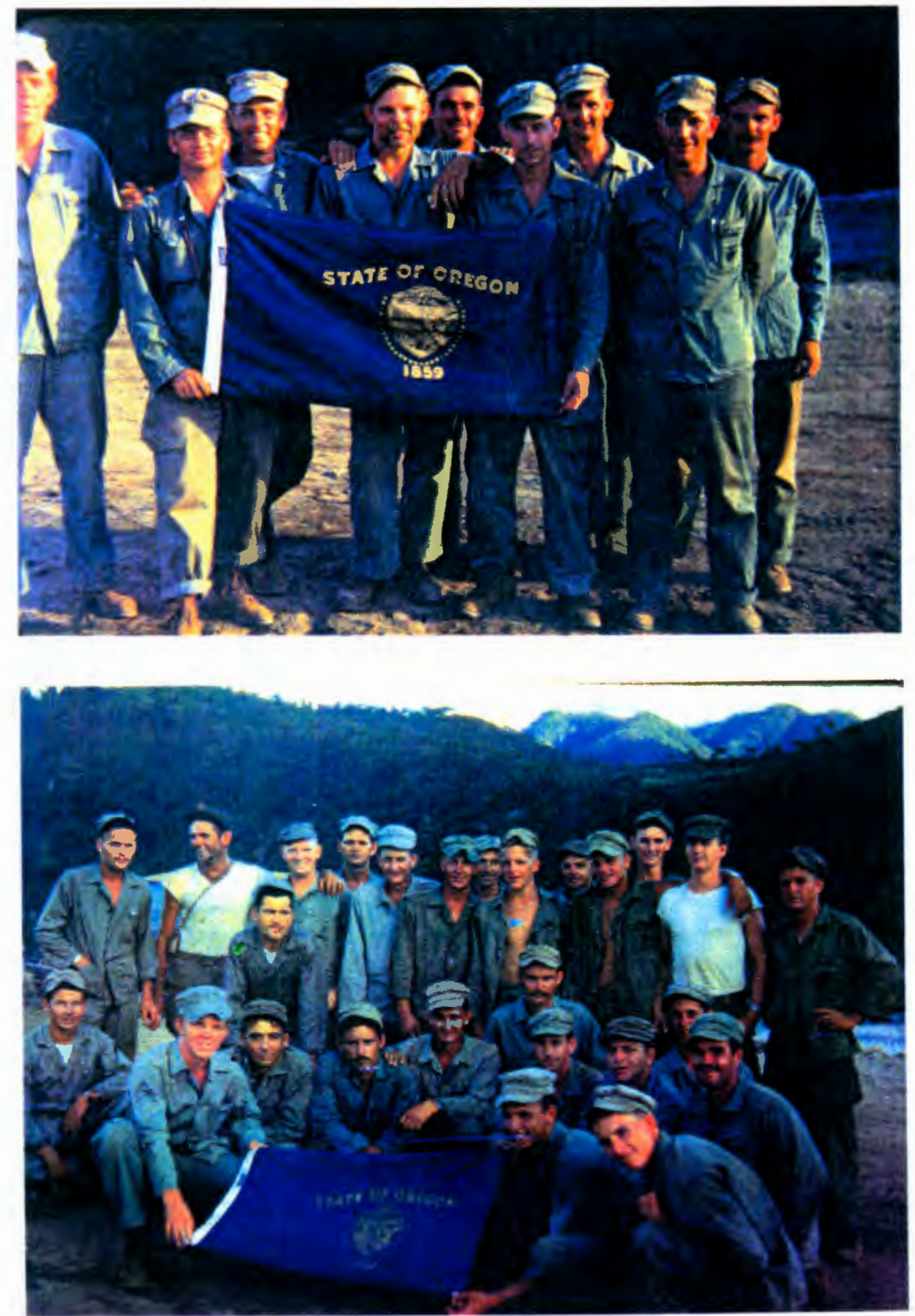

Figure 78 and 79: Oregon Marines in Korea during happier times prior to the Battle of the Chosin Reservoir, fall 1950

Photos courtesy of Oregon Chapter of Chosin Few Collection 


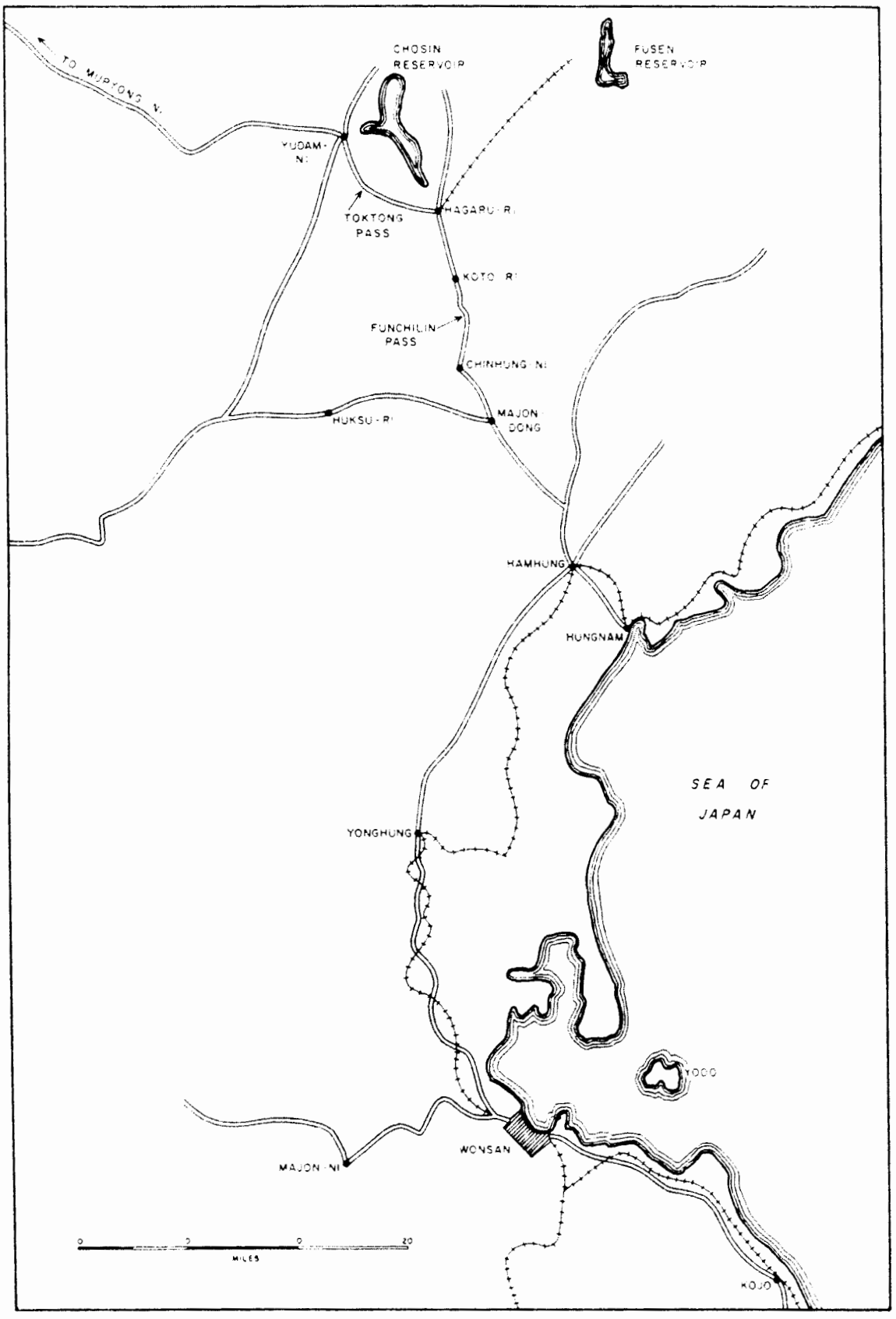

Road Net Leading to the Chosin Reservoir

Figure 80. Map of Chosin Reservoir region. Korea. November and December 1950 Soldiers of the Sea by Heinl, p 566 
Chinese rounds were mortar, machine gun, and rifle fire. Private First Class Ralph E. Newman Jr., of Eugene, reported that he had Chinese on most of his radio nets during this period. Corporal James R. Whitcomb, of Beaverton, was assigned to Gun \#6, which normally had a crew of 9 Marines, setting fuses and cutting charges for each individual $105 \mathrm{~mm}$. round. He recalls that on the occasion when Battery $\mathrm{H}$ was almost overrun by Chinese infantry outside of Hagaru-Ri, he was setting the artillery fuses as low as possible (using \#1 powder charge) so that the rounds exploded a mere 75 feet from the muzzle of his howitzer. The entire battery was in the direct fire mode on this occasion with all bore siting being done directly down the gun barrel. The ground was so frozen that the gun trails could not be dug in, so that each time the howitzer fired, the entire gun leaped dangerously backward. During this close in attack, several Marines were killed and over a dozen were wounded, (including the battery commander), by mortar, grenade, and small arms fire. Every Marine not actually manning a howitzer (officers, senior enlisted, radiomen, drivers, mechanics, and Navy corpsmen) served as infantry. This further validated, as it had been proven previously on Saipan, the essential Marine tenet that every Marine is a rifleman. Another basic trade which gained increased validity here was the crucial importance of close air support by Marine aviation. One Marine after another recalled with special meaning just how close and effective the F4U Corsairs were at bombing, rocketing, and strafing Chinese formations within 100 yards of Marine positions. Napalm was used to great physical and psychological affect. Words like 
"fearless" and "great" were repeatedly used by Marines on the ground who stated that they could clearly see the faces on the Marine pilots.

Corporal Thomas G. Green was a former member of 4th 105 Howitzer Battalion in Portland. Like the majority of the Oregonians, he had been placed in 3rd Battalion, 11 th Marine Artillery Regiment. Between the regiment's Headquarters and Services Battery, Battery G, Battery H, and Battery I, most of the Oregon Marines had gone to the latter two batteries (known as "How" and Item" batteries). In Korea, since landing at Inchon, Green had served as an ammunition-demolition technician with Headquarters and Services Battery, 3rd Battalion, 11th Marine Artillery Regiment. At Yudam-Ni, he was attached to Company D and E, 2nd Battalion, 7th Marine Regiment. Following the last Marine push north, these two infantry companies had but 44 Marines, so a dozen artillerymen had been augmented to them as infantry. On the withdrawal to Hagaru-Ri, Green was again assigned out as an infantryman. But this time to Company G, 3rd Battalion, 5th Marine Regiment. In the struggle to reach Koto-Ri, he remembers his column of Marines following a tank and a bulldozer, the latter passing the tank to fill in road craters whenever the Chinese tried to block the road with an obstacle. When the bulldozer operator was killed by a sniper, an artilleryman from Texas with a farming background took over clearing the road of obstructions and filling in craters with the dozer. The Texan later received a Silver Star Medal for his initiative and courage. The tank was the main source of covering fire for both the infantry and the bulldozer. Having struggled in the snow on his feet from Yudam-Ni to Koto-Ri, and with the temperature 


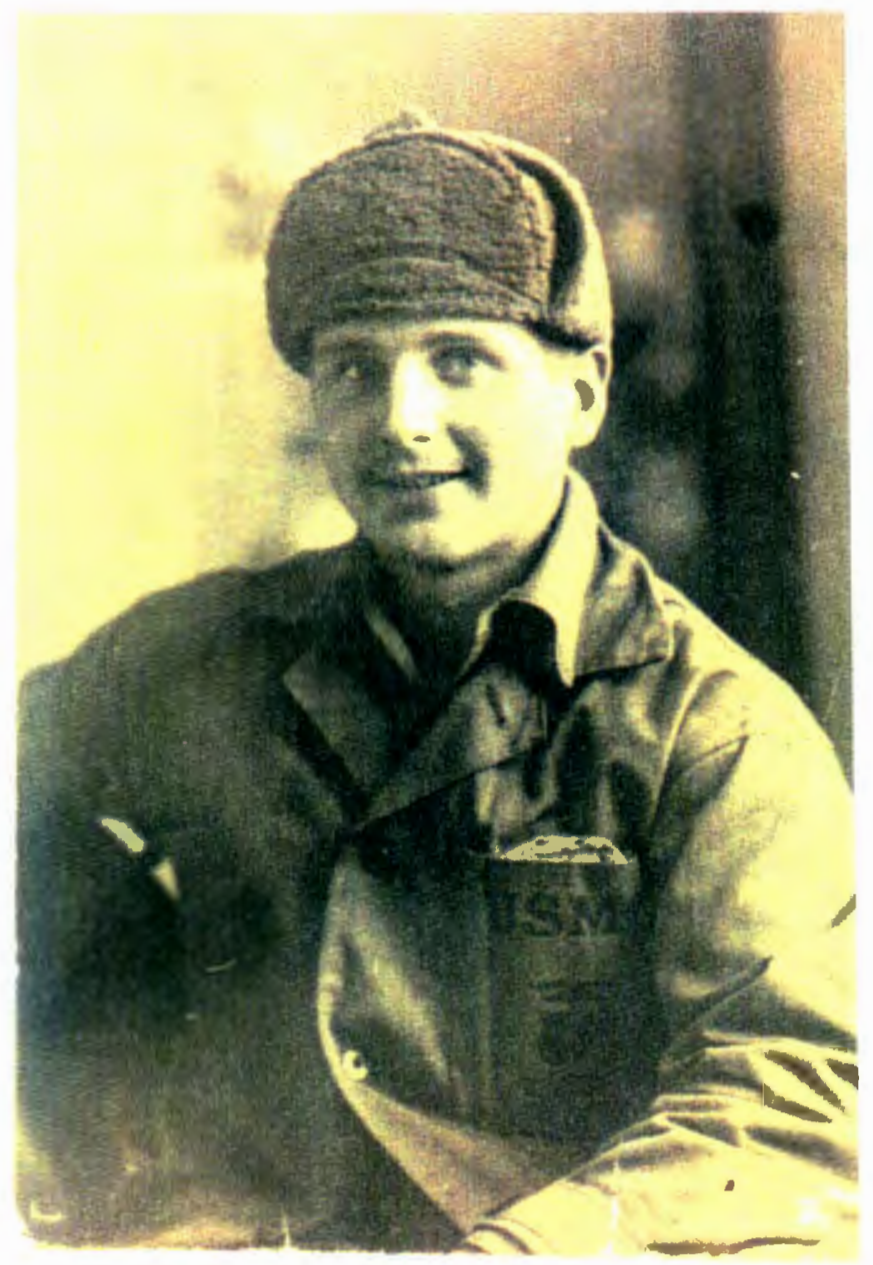

Figure 81: Thomas G. Green of Portland, Oregon, serving in Korea with 11th Marine Artillery Regiment, 1st Marine Division. A graduate of Central Catholic High School, he had previously been a member of Portland's 4th 105 Howitzer Battalion. He later founded the Oregon Chapter of the Chosin Few.

Photo courtesy of Thomas G. Green Collection 
at 21 degrees below zero, Corporal Green passed out in formation on 7 December 1950. His socks were frozen to his feet. When he came to in a Koto-Ri first aid station, he remembers a Navy corpsman leaning over him and asking "where he was hit," and his response that "he didn't remember getting hit." After a few hours of sleep in the warm tent, he was placed in the cab of an ammunition truck, where he rode shotgun all the way back to Hungnam. Corporal Green was eventually discharged from the Marine Corps in 1952. He later organized and became the first president of the Oregon Chapter of the Chosin Few. His best Marine Corps memory is marching into Hagaru-Ri on the night of 3 December 1950, with the 5th Marine Regiment, followed by the 7th Marine Regiment. ${ }^{148}$ Despite sub-zero weather, being outnumbered and cut off, they had broken through. More fighting remained, but these Marines were confident that they would endure. Both regiments were badly hurt but in good order. They had brought their wounded, their dead, and their equipment with them and were cheered by their fellow 11th Marine Artillery Regiment. Truly, "a band of brothers" the bulk of 1st Marine Division went hoarse singing the Marine Hymn upon entering Hagaru as a reunited unit. $^{149}$

David Dowdakin was another WWII veteran who was recalled to active duty on 12 September 1950 for the Korean War. As a member of Company C (squad leader),

\footnotetext{
${ }^{1+8}$ Personal Interview between T. G. Green and author, Portland, Oregon, 9 December 1993.

${ }^{149}$ Benjamin S. Read, "Our Guns Never Got Cold," The Saturday Evening Post, April 7, 1951, p. 147.
} 


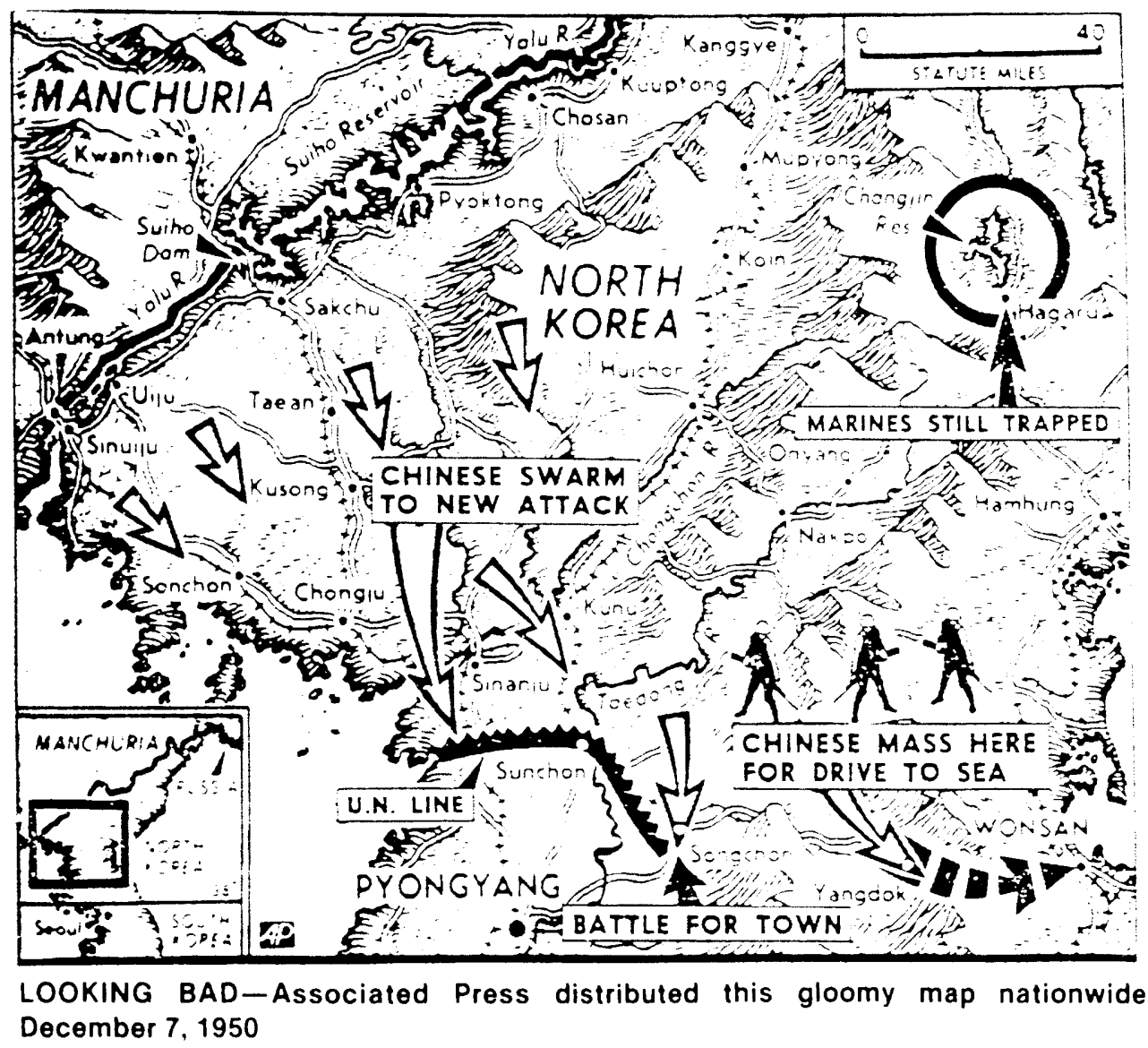

Figure 82: 1st Marine Division reported trapped and surrounded bv ten Chinese divisions. December 1950 .

Map courtesy of Chosin Few Association 
1st Battalion, 7th Marine Regiment, 1st Marine Division, he participated in and survived the ordeal of the Chosin Reservoir in November and December of 1950. Here he participated in the advance to Yudam- $\mathrm{Ni}$, and the fighting withdrawal back to Hagaru- $\mathrm{Ri}$, Koto-Ri, and the coast. Following his release from Oakland Naval Hospital, where he recovered from frostbite obtained at Yudam-Ni and Hagaru-Ri (five nights without sleeping bags, which were lost to the Chinese in an ambushed truck). Discharged from the Marine Corps on 25 May 1951, Dowdakin would volunteer again in 1993 to serve in Portland both on the steering committee and as secretary for the Marine Corps Coordinating Council of Greater Oregon. ${ }^{150}$

The 1st Marine Division reached the sea at Hungnam on 11 December 1950. It emerged from the cold, rugged mountains tired, intact, and proud. Marine losses were 730 killed and 3,670 wounded. From their own records, three Chinese armies were finished and disappeared from their order of battle. Their losses were an estimated 25,000 killed, and 12,500 wounded.

For the 1st Marine Division, an amphibious redeployment to the southeast followed. It would later spearhead the 1951 United Nations spring offensive and then stem the tide of the 1951 Chinese counteroffensive, which resulted in the initiation of armistice talks. By the spring of 1952, the 1st Marine Division was deployed astride the corridor north of Seoul, anchoring the United Nation's left flank, and overlooking the 3 October 1994.

${ }^{150}$ Personal Interview between D. W. Dowdakin and author, Portland, Oregon, 
Panmunjom truce site. Two and a half years of savage but inconclusive fighting followed the Chosin Reservoir. The Korean War armistice was finally signed on 27 July 1953.

Hostilities ended in Korea with the Marine Corps having suffered 4,262 Marines killed and 21,781 wounded. This was more than twice the casualties sustained by Marines in World War I. Marines had earned 42 Medals of Honor, 28 of them posthumously. ${ }^{151}$ The 1st Marine Division had proven itself to be the war horse of the United Nations Forces in Korea, and the Oregon Marines of 4th 105 Howitzer Battalion, the 17th Engineer Company, and many other active duty units, had maintained the highest standards and traditions of the Corps.

One singular story from this general period of Oregon Marine Corps history is that of the Martinez family, better known as "a Marine recruiter's dream come true." Residing in what may best be described as the Portland, Beaverton, and Madras areas, this is the story of nine brothers, eight of whom joined the Marine Corps and served their country through World War II, Korea, and Vietnam. Sons of Nelse and Della Martinez, all joined at the age of 17 . Ernest Martinez (\#1) was the first to join and establish a proud tradition by serving in World War II; John Frederick Martinez (\#2) and Ralph James Martinez (\#3) joined together and later served in Korea with their brother Robert Nelse Martinez (\#4); Raymond Leroy Martinez (\#5), Joseph Anthony Martinez (\#6), and Lawrence Dennis Martinez (\#7) all served during the Cold War interim between Korea and Vietnam; and Frank William Martinez ( $\# 8$ ) rounded out a fine tradition by serving

${ }^{151}$ Heinl, Soldiers of the Sea, p. 589. 
in Vietnam. For some unexplained reason, Daniel Benjamin Martinez (\#9) never joined the Corps. Sergeant Ralph James Martinez (\#3) continues to serve as the Vice-president of the 1st Marine Division Association of Oregon. He states that his best Marine memory is from 1953, when he was serving with Company F, 2nd Battalion, 5th Marine Regiment, on the western front in Korea. Here, in the middle of a war, he was able to link up with and spend some precious time with his brothers John (\#2), who was serving with 1st Amtrac (Amphibious Tractor) Battalion, and Robert (\#4), who was with 11 th Marine Artillery Regiment. All three were members of 1st Marine Division. The Martinez brothers were predominantly infantrymen, with the artillery, armor, and aviation fields also being represented. At present, one of the major challenges for Marines attending the annual 10 November Marine Corps Birthday Ball, in Portland, is simply to remember each Martinez brother's nickname.

Even while the Korean War was still being waged, the Marine Corps Reserve in Portland, Salem, and Eugene was being reestablished. On 20 November 1951, the 8th Engineer Company was formed on Swan Island, followed on 4 December 1951 by a second engineer unit, the 2nd Engineer Field Maintenance Company. In Salem, the 3rd $155 \mathrm{~mm}$ Gun Battery was formed in November 1951, while the 1st $155 \mathrm{~mm}$ Gun Battery was established in Eugene. These were the extremely lean years, for as Lieutenant Colonel Faltyn of Salem later recalled: "Most Marine veterans in the area had already 


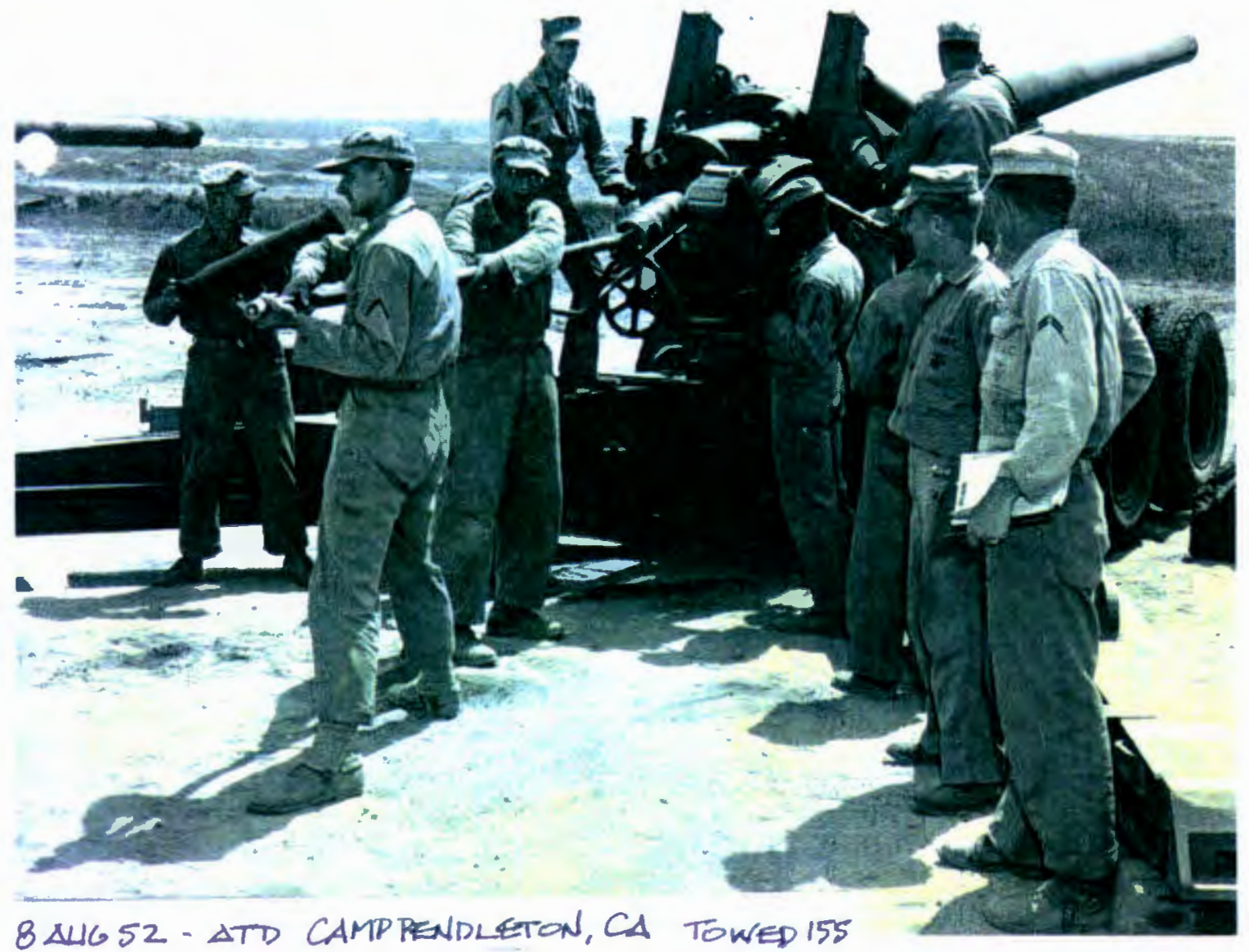

Figure 83: Oregon's Marines returned from the Korean War and were reestablished in 1951. Salem and Eugene traded their $105 \mathrm{~mm}$ howitzers for $155 \mathrm{~mm}$ howitzers, while Portland converted entirely to engineer units. Here, Marine reserve artillerymen of 2 nd 155 Gun Battery, Eugene and 3rd 155 Gun Battery, Salem train at Camp Pendleton, California, August 1952.

Photo courtesy of Salem Marines' Command Historical Summary File 


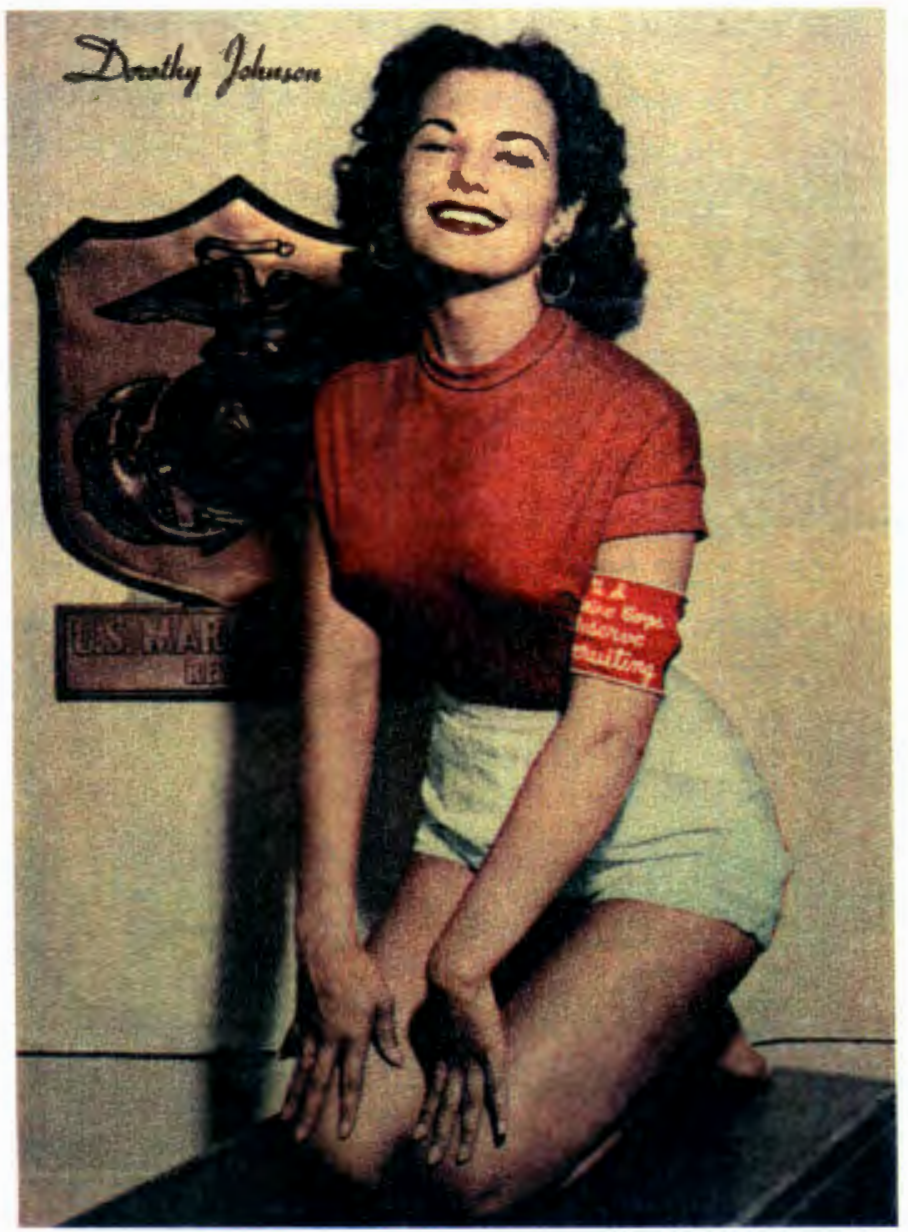

Figure 84: Life in the Marine Corps Reserve did have its lighter moments. In 1953, Miss Dorothy Johnson was selected as "Miss Marine Corps Reserve" and to confirm Marines' good taste, Miss Johnson went on to become "Miss Oregon" in 1955.

Photo courtesy Leatherneck, Magazine of the Marines, October 1955, p. 49. 


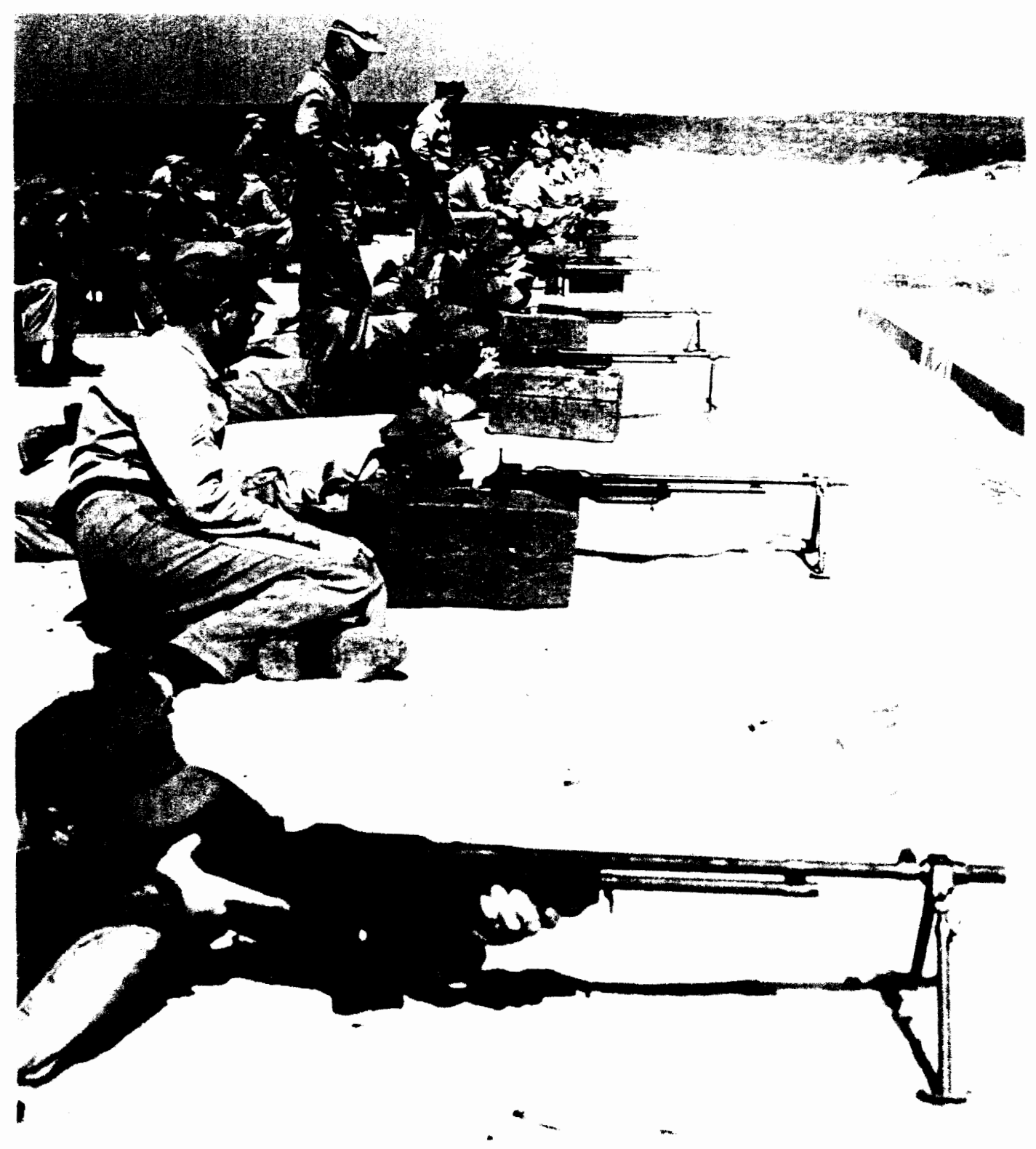

Figure 85 Oregon Marines requalify on the Browning Automatic Rifle at Camp Pendleton. California during annual training 1954

Photo courtesy of Salem Marines' Command Historical Summary File 


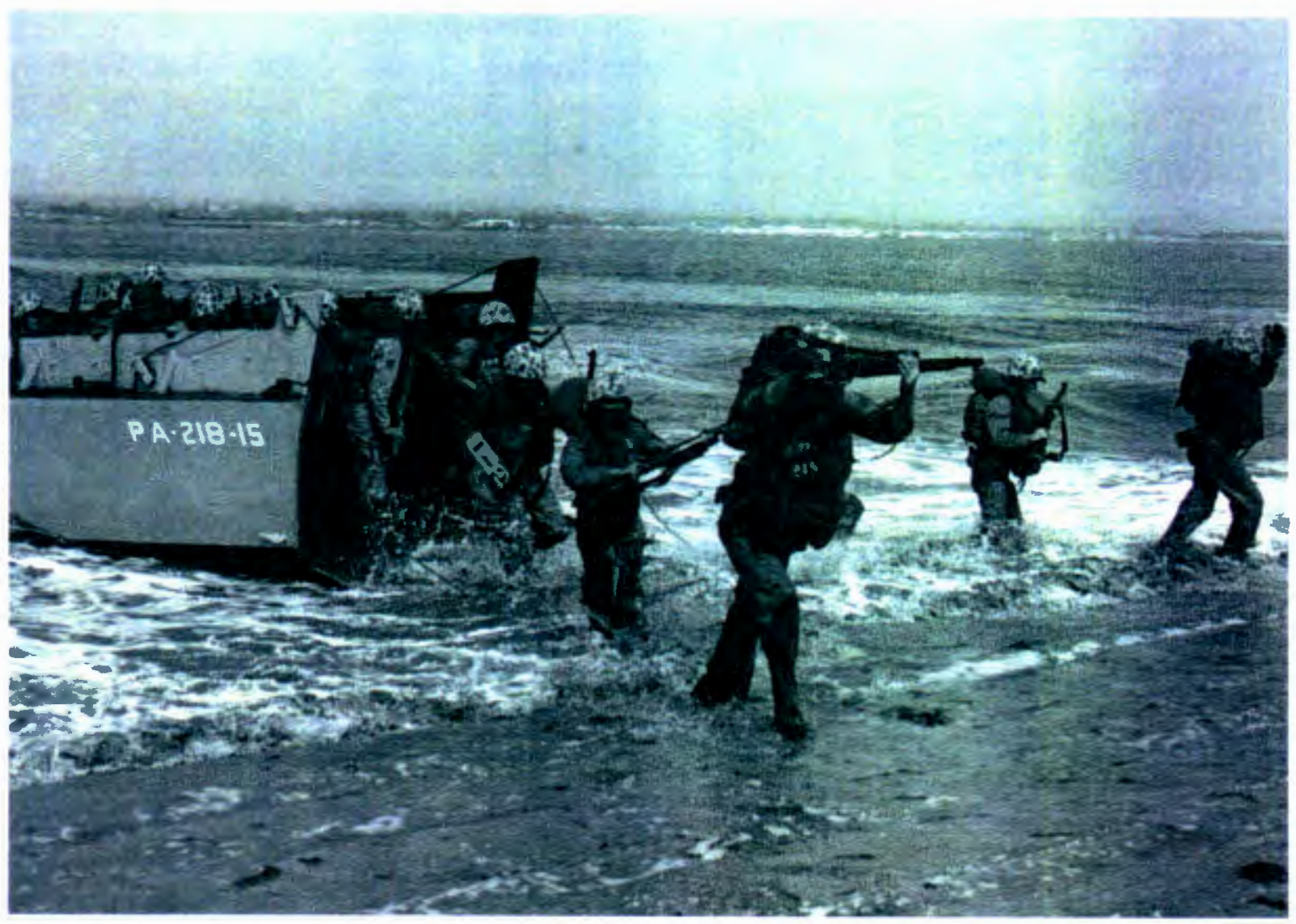

Figure 86: Oregon Marines conduct amphibious landing operations in southern California during annual training 1954.

Photo courtesy of Salem Marines' Command Historical Summary File 

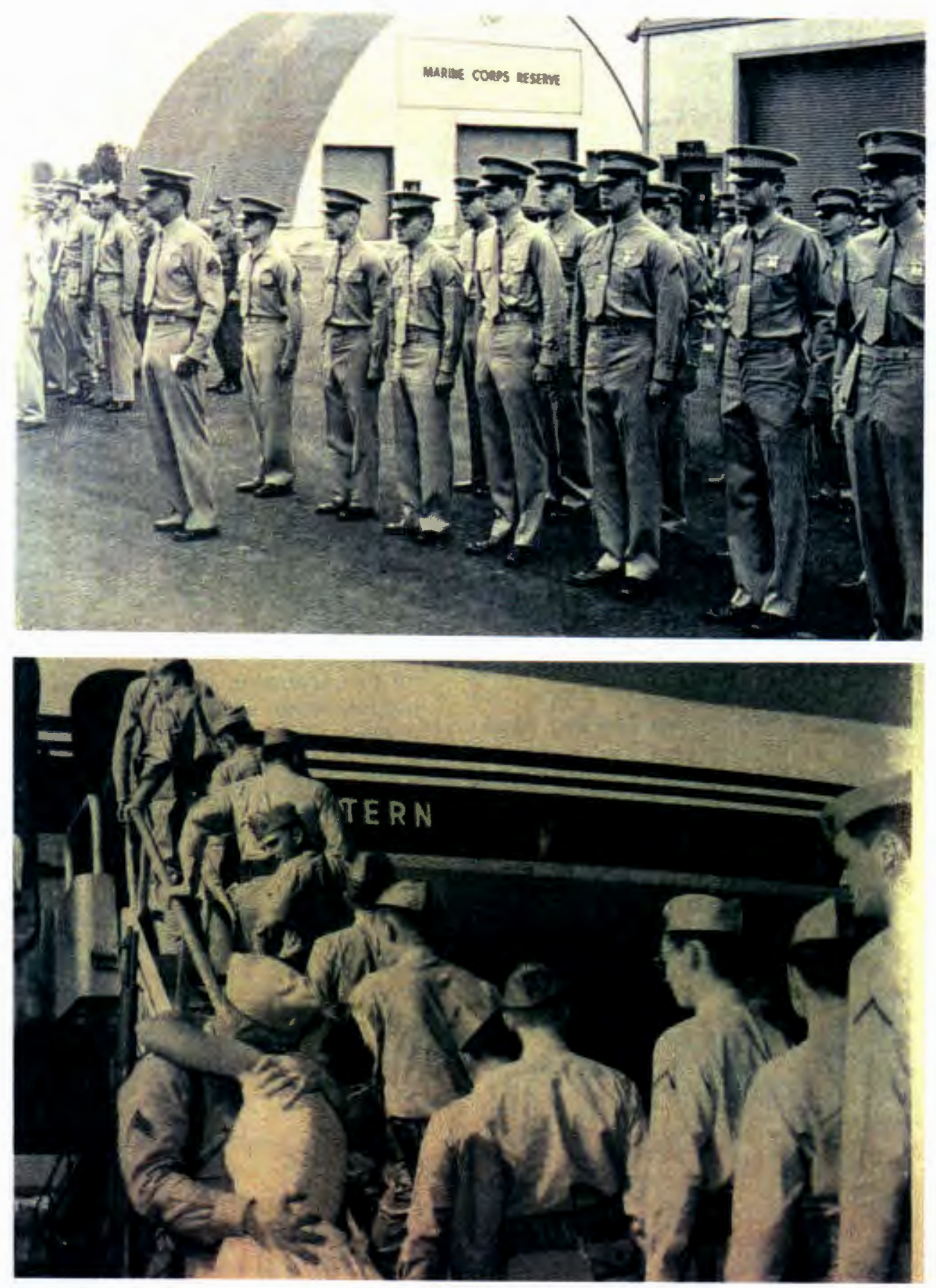

Figure 87 and 88: Portland Marines of 2nd Engineer Field Maintenance Company and 8th Engineer Company form up and depart for 1955 annual training period.

Courtesy: Leatherneck magazine, October 1955, p. 46 
served in two major wars, and their families were hesitant to risk them again." ${ }^{152}$ Faltyn, who had earned a Navy Cross and two Purple Hearts on Iwo Jima, was a captain serving in the Salem unit during this period. Despite being designated as a battery (a company size unit which should average about 100 Marines), the unit consisted of but a dozen or so Marines. The situation was virtually the same in Eugene, and not much better in Portland. Faltyn would command the Salem Marines from 1954 to 1958, and he reported that during this period the personnel situation improved a great deal as new Marines were brought on board.

On 1 November 1957, the two engineer companies at Portland were redesignated as the 3rd Engineer Battalion, to include a Headquarters Company, a Services Company, an Engineer Company, and Engineer Field Maintenance Company. Eugene and Salem remained as the 1st and 3rd 155 Gun Batteries, but with a self-propelled (SP) designation. Unit strengths were now approaching their approximate 100 Marine per company historic average. On 3 November 1957, Portland had a strength of 27 officers and 265 enlisted Marines.

A series of Pacific Northwest Marine unit redesignations took place on 1 July 1962, when the Portland unit was changed to 5th Engineer Battalion. As components of this same battalion, the Salem Marines became Company A, Eugene became Company B, and the former 93rd Rifle Company of Seattle was changed to Companies C and D, 1994.

${ }^{152}$ Personal Interview between H. J. Faltyn and author, Portland-Salem, 15 April 

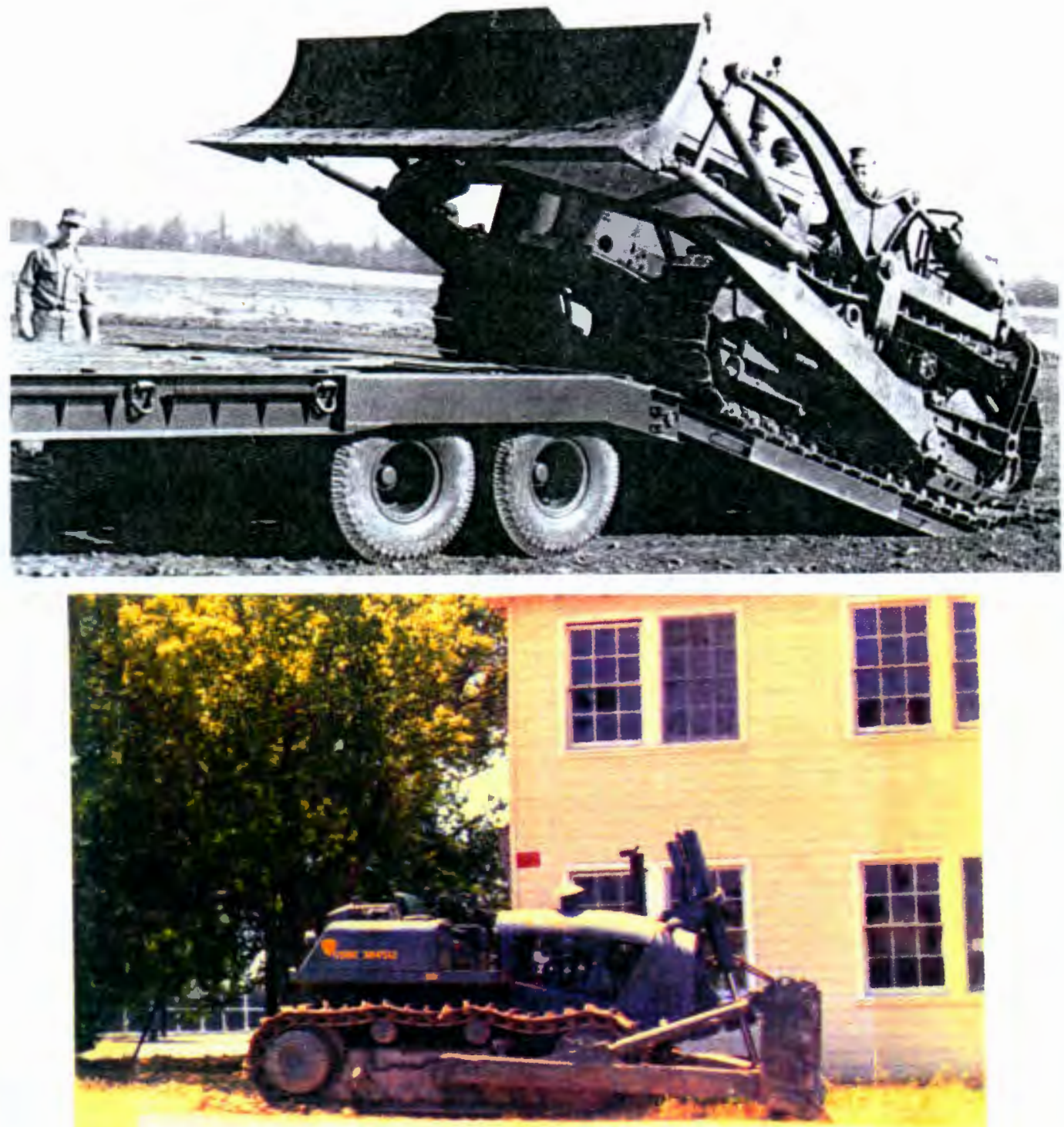

Figure 89: Oregon Marines of 3rd Engineer Battalion on-load a vintage World War II - Korean War era TD-18 bulldozer onto a lowbed trailer for transport. Circa 1957 to 1962 .

Figure 90: The Euclid 8230 bulldozer was the replacement for the venerable old International Harvester TD-18. Here, a new 8230 of Oregon's 5th Engineer Battalion, awaits a project during annual training at Marine Corps Air Station El Toro, California. Circa 1962 to 1967.

Salem Marines' Command Historical Summary File 
5th Engineer Battalion. Total strength of 5th Engineer Battalion was now approximately 500 Marines. Also of interest is that in the Midwest, the Marine Reserve unit at South Bend, Indiana, was redesignated as the reactivated headquarters of 6th Engineer Battalion. This was the same unit which had originally been activitated back in 1944 on Guadalcanal, and had distinguished itself so highly in 1945 as a part of 6th Marine Division during the Battle for Okinawa. It had been deactivated in China in 1946. Back in the Marine Corps order of battle, 6th Engineer Battalion was to remain in South Bend, Indiana, until 1 October 1971, when this proud name and tradition was transferred to Portland, Oregon.

These were years of relatively routine training in which instead of drilling one night per week for two hours, the units switched to one entire weekend per month. There still existed the traditional two weeks of active duty at a Marine Corps installation. This period was known to Marines as "summer camp" and for the Oregon Marines, this period usually took place in the June or July time frame at either Camp Pendleton or 29 Palms, California. The other change that took place was that instead of going by train, aircraft had now became the standard method of troop transport.

During this period, the Marine Corps maintained its structure of three divisions being supported by three aviation wings. 1st Marine Division was on the West Coast (Camp Pendleton), 2nd Marine Division was on the East Coast (Camp Lejeune), while 3rd Marine Division was split between Okinawa and Hawaii. Most of the Portland, 5th Engineer Battalion training focused on support of 1st Marine Division engineer assets 
(1st Engineer and 7th Engineer Battalions). This period of relative routine operational activity following the Korean War was not to last long for the Marine Corps. 


\section{CHAPTER VII}

\section{VIETNAM AND COLD WAR VICTORY}

"The Marines' best propaganda has usually been the naked event."152

Marc Parrott: Hazard, 1962

"The appearance of Marines on foreign soil has always in the past indicated the beginning of extremely dangerous military adventures. "I53

Article in Krasnaya Zvezda (Soviet Red Star, 16 March 1965)

"For those who fight for it, freedom has a taste the protected will never know."

Carving in overhead beam, Marine bunker beseiged firebase at Khe Sanh, Vietnam Tet Offensive, 1968

The decade following Korea clearly indicated that despite the ever-present threat of nuclear war, the characteristic pattern of the Cold War was one of limited operations and confrontations. This form of politico-military guerrilla warfare was in short the type of small war in which the Marine Corps had become so well versed in the first 150 years

${ }^{152}$ Heinl, Dictionary of Military and Naval Quotations, p. 184.

${ }^{153}$ Ibid., p. 184. 
of its history. In Asia, from 1955 to 1963, Marines landed in Taiwan, Laos, Thailand, and South Vietnam to counter communist pressure. In the Mediterranean, Marines landed in 1956 at Alexandria, Egypt, to help evacuate American and foreign nationals during the Suez Crisis. In 1958, a Marine brigade landed in Lebanon at the request of the government to secure Beirut against a communist coup. In the Caribbean, the 1962 Cuban Missile Crisis saw Marines in force aboard both Navy shipping and at Guantanamo Bay, maintaining pressure on Cuba and its communist leader, Fidel Castro. The Dominican Republic was the focus of Marine attention in 1965, when Castroite communists attempted to gain power. The landing of a Marine brigade showed, as it had so many times before, that America was ready to intervene when national interest so dictated

Unfortunately, on the other side of the globe, the prolonged war in Vietnam heated up. America made the fateful choice of supporting the Republic of South Vietnam in its defense against communist North Vietnam. On 8 March 1965, elements of the 3rd Marine Division landed to secure the airbase at Danang, South Vietnam. Despite years of covert involvement, these were the first major American ground units to enter the war. This landing was subsequently followed by the 1st Marine Division, and within two years, almost two-thirds of the Marine Corps was actively committed to the Vietnamese war. From late 1965 on, this combat would be characterized by sustained patrolling, ambushes, and intermittent battles. By late 1966, roughly 60,000 Marines (almost $20 \%$ of all American forces in Vietnam) were ashore and in the field. 


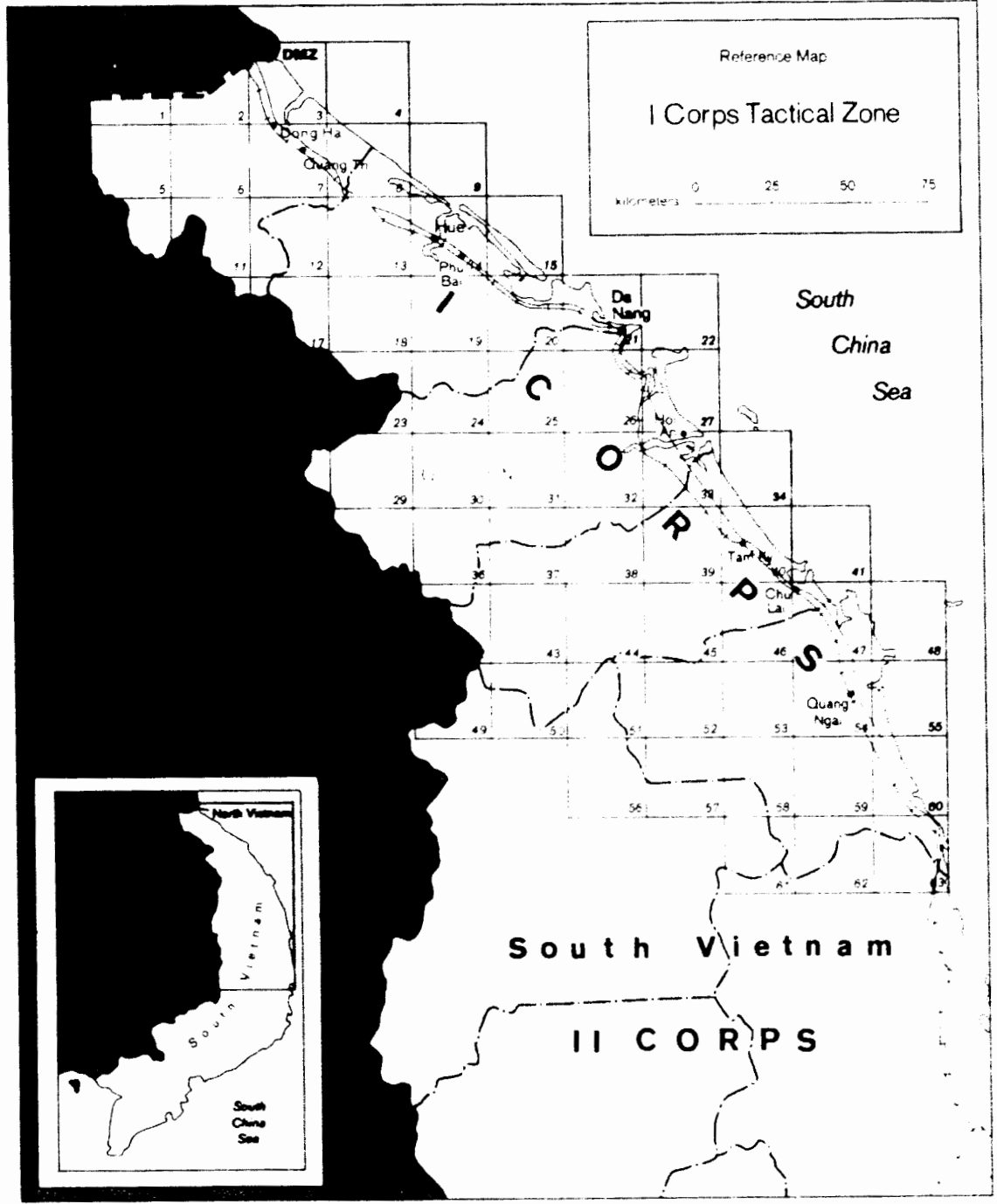

Figure 91: Map of I Corps Tactical Zone, the area of responsibility for the Lnited States Marine Corps in Vietnam

Courtesy of Marine Corps Historical Center 
These units included elements from the newly reactivated 5th Marine Division, which by 1967, had pushed Marine Corps strength past that of Korea, and was surpassed only by that at the end of World War II. The United States was again at war and, as usual, the Marines, including those from Oregon, were in the thick of it.

On 21 April 1967, Private First Class Gary W. Martini, of Portland, Oregon, was serving as a rifleman with Company F, 2nd Battalion, 1st Marine Regiment, 1 st Marine Division. While conducting offensive operations during Operation Union, at Binh Son, Republic of South Vietnam, Martini's unit encountered a firmly entrenched enemy force. Deploying to engage the enemy, Martini's platoon assaulted across an open rice paddy amid incoming mortar fire to within approximately 60 feet of the enemy positions. Here the Marine platoon was halted by a barrage of grenades, machine gun, and small arms fire, which killed 14 and wounded 18 Marines. The remainder of the platoon was pinned down behind a low paddy dike. In the face of imminent danger, Private First Class Martini immediately crawled over the dike to within 45 feet of the enemy, where despite hostile fire, he repeatedly hurled grenades into the enemy trenchline, killing several of the enemy. He then raced through the open area and dragged a comrade back to the relative safety of the friendly position. During this effort, he received a serious wound. Again disregarding his own safety, he again braved intense fire to aid another Marine even closer to the enemy positions. Upon reaching his comrade, Martini received a mortal wound, but ignoring his own condition, he began to drag his buddy toward friendly lines. Observing that other Marines from his unit were preparing to leave the security of their 

positions to assist him, and concerned only for their safety, he called to them to remain under cover. Through a final supreme effort, he moved his injured friend to where he could be pulled to safety, before succumbing to his wounds. For his stout-hearted and indomitable courage under fire, in which he unselfishly yielded his own life to protect his unit and save the lives of two of his fellow Marines, Private First Class Gary Martini was awarded the Congressional Medal of Honor ${ }^{154}$ Today, the Eugene Chapter of the Marine Corps League is proudly named in his honor.

Meanwhile, back in Oregon, the Marine Reserve was preparing to be activated. This, however, would not occur. On 1 February 1967, the 5th Engineer Battalion, in Portland, was redesignated as the 10th Engineer Battalion. The Portland Marines had an average strength of approximately 298 Marines at this time. The Salem Marines, with a reported onboard strength of 110 Marines, became Company A, 10th Engineer Battalion. The Eugene unit, with a strength of 100 Marines, was redesignated as Company B, 10th Engineer Battalion. The Marine Reserve continued to train and remain ready.

Oregonians on active duty continued to serve. Lance Corporal William Edward O'Connor was born in Salem, Oregon, on 7 December 1946. He joined the Marine Corps there on 9 June 1966, and by 15 November 1966, was in action in Vietnam as the third Marine, in the 3rd Fire Team of the 3rd Squad of Company C, 1st Battalion, 3rd

${ }^{154}$ Sharp and Dunnigan Publications, The Congressional Medal of Honor: The Names, The Deeds, (Chico, California, 1984), p. 106. 

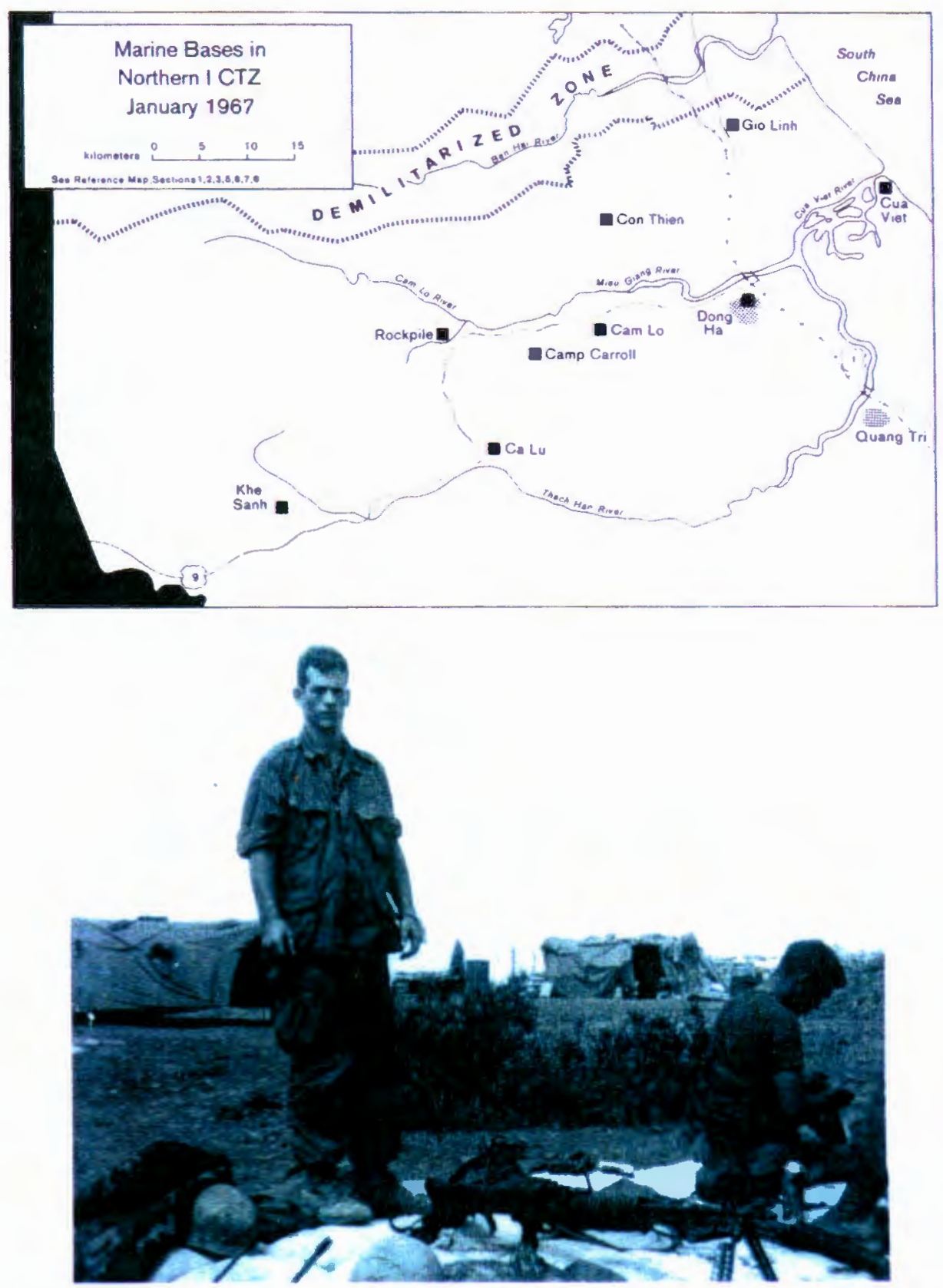

Figure 93: Marine Bases in I Corps Tactical Zone, northernmost area of South Vietnam, 1967.

\section{Courtesy Marine Corps Historical Center}

Figure 94: William E. O'Connor, of Salem, who served with Company C, Ist Battalion, 3rd Marine Regiment, 3rd Marine Division in Vietnam. He would later retire from the Marine Corps out of Company A, 6th Engineer Support Battalion, Salem.

Courtesy William E. Q'Connor Collection. 
Marine Regiment, 3rd Marine Division. One of the heaviest Marine Corps engagements in Vietnam, prior to the Tet Offensive of 1968, was Operation Buffalo. On 2 July 1967, just northeast of Con Thien (south of the De-Militarized Zone), Companies A and B of 1st Battalion, 9th Marine Regiment, were making a sweep when they were ambushed midmorning by the 90th Regiment of the North Vietnamese Army. Company B was completely cutoff and hit by artillery, mortars, grenades, machine gun, small arms fire, and even flame throwers. Within hours, by the time a relief force broke through from Con Thien, 84 Marines (including the entire command group of Company B) had been killed and another 190 wounded. Those that survived stated that had it not been for Marine air dropping napalm as close as 20 yards from their position, and disrupting the enemy assault, they would have been exterminated. Lance Corporal O'Connor's unit was part of this relief force. September 1967 found him participating in Operation Shelbyville, in the Quang Nam Province of the Republic of Vietnam. At about noon on 26 September 1967, while assaulting a village defended by a North Vietnamese Army unit, the Marine just forward of him stepped on an enemy anti-personnel mine. The blast sprayed shrapnel into O'Connor's face and chest, blinding him for a short time and resulted in his being evacuated by helicopter to the USS Okinawa offshore. He later recovered, and in March 1975, joined the Marine Reserve unit in Salem, where he retired as a Staff Sergeant in September 1990. Partially disabled from his wounds, Staff Sergeant O'Connor still struggles with a sense of guilt that had he not been hit that day, he would have been able to save more of his less experienced buddies. While O'Connor 


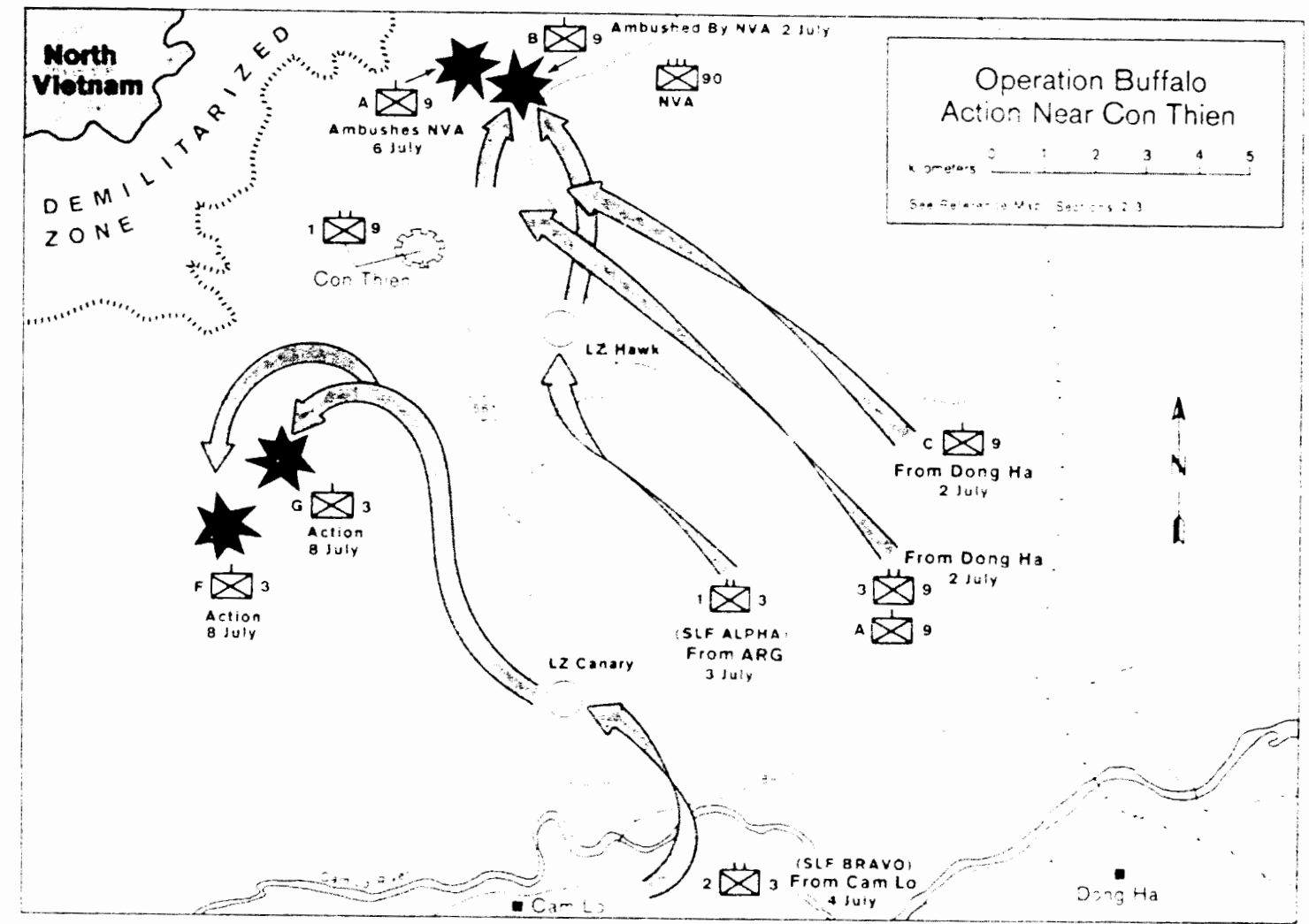

Figure 95 Map of Operation Buffalo, Con Thien region of Vietnam. July 1967 Several Marines from Oregon were involved in this operation, which saw some of the heaviest action of the Vietnam $W$ ar prior to the 1968 Tet Offensive In this savage battle alone. from 2 to 14 July 1967,159 Marines were killed and $3+5$ were wounded

Courtesy of Marine Corps Historical Center 
was recovering from his wounds, on 11 October 1967, 2nd Lieutenant Abram J. Walker and the remainder of $O^{\prime}$ Connor's platoon were overrun. Seven Marines were killed (including the lieutenant) and 14 were wounded. All told, Company C suffered 106 casualties over this four-month period of $1967 .{ }^{155}$

Another Marine involved in Operation Buffalo was Alfredo Juan Arguedas, of McMinnville, Oregon. Serving as a Corporal with Headquarters and Services Company, 2nd Battalion, 3rd Marine Regiment, he had arrived in Vietnam in July of 1966 and was brought in with his battalion by helicopter from Cam Lo on 4 July 1967 to reinforce the serious situation around Con Thien. As a junior enlisted Marine working close among this infantry battalion's senior officers and enlisted men, a deep and lasting impression was made on Arguedas regarding Marine "esprit de corps" and professionalism. He later stated that he truly loved these fellow Marines in a manner which is best expressed by the famous "band of brothers" speech in Shakespeare's Henry V. In the time-honored tradition of Marines taking care of their own, both O'Connor's and Arguedas' sister battalions now played a prominent role in crushing the enemy regiment. Operation Buffalo and the vicious July 1967 fighting around Con Thien did not breed Marine overconfidence, for between 2 to 14 July, 159 Marines had been killed and 345 wounded. Enemy losses were 1,290 killed. Marine faith in supporting arms was reaffirmed, for as both Arguedas and O'Connor agree, their best Marine Corps memory

\footnotetext{
${ }^{155}$ Personal Interview between W. E. O'Connor and author, Portland, Oregon, 16 April 1994.
} 


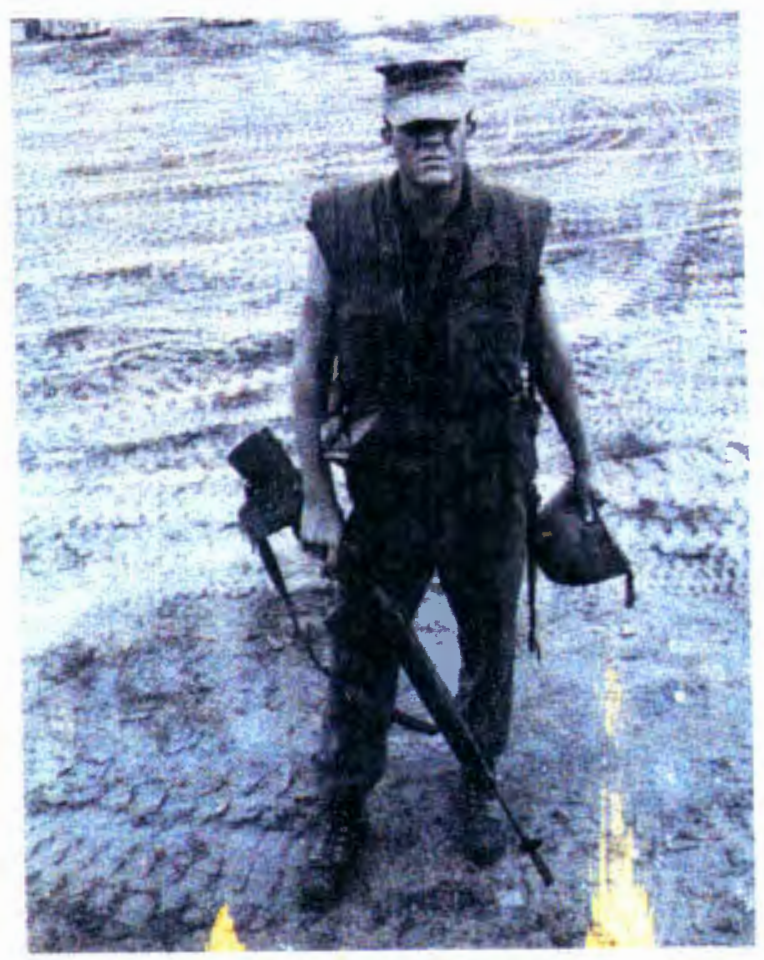

Figure 96: Alfredo J. Arguedas of McMinnville, who served with H\&S Company, 2nd Battalion, 3rd Marine Regiment, 3rd Marine Division in Vietnam, 1967. He would later command 6th Engineer Support Battalion out of Portland, from 1992 to 1994.

Photo courtesy of Alfrede I Arguedas Collection 
was air and artillery support in Vietnam. Arguedas left Vietnam in August 1967 and following completion of college, was commissioned as a Marine second lieutenant in June of 1972. Following his active duty tour, he transferred to the Marine Corps Reserve and eventually took command of the Salem Marine Reserve engineer company from 1985 to 1987 . He later served in Norway when activated for the 1991 Gulf War (Operation Battle Griffin display of NATO force for the benefit of Soviet Union), and as a Lieutenant Colonel, took command of the Portland Marine Reserve engineer battalion from 1992 to 1994 . Now a Colonel, and still active in the Oregon Marine community, his emphasis on leadership, readiness, and tradition has left a lasting impression on those Oregon Marines currently on watch. ${ }^{156}$

In 1968, the full scale communist Tet Offensive took place. Despite an across the board tactical victory for American forces (the Marine Corps particularly distinguished itself at the Battles of Hue City and Khe Sanh), the Tet Offensive was a major political and psychological defeat for the United States. North Vietnam demonstrated that no matter what the price, it would continue to fight a war of attrition. The American people, however, were no longer as willing to sacrifice lives in an unclear cause. In Vietnam, the Marine Corps continued to carry out its historic mission of "closing with and destroying the enemy." Marine Corps strength peaked in Vietnam in 1968, with 85,520 personnel serving there.

${ }^{156}$ Personal Interview between A. J. Arguedas and author, Portland, Oregon, 16 April 1994, also G. L. Telfer, L. Rogers, and V. K. Fleming, Jr., US Marines in Vietnam, Fighting the North Vietnamese, 1967, (Washington, D.C.), p. 104. 
Marine Gunnery Sergeant Percy Eugene Brandon, holds the distinction of being Oregon's recipient of the most Purple Heart Medals: six in Vietnam. A Sioux Indian from Grande Ronde, Oregon, "Gunny" joined the Marine Corps in Portland on 19 January 1953. His older brother Howard Spencer Brandon $\mathrm{Jr}_{r}$, had been killed in action on Iwo Jima. Brandon arrived in Vietnam 27 December 1967, as the company gunnery sergeant for Company F, 2nd Battalion, 4th Marine Regiment, 3rd Marine Division. On 4 March 1968, he received his first shrapnel wound at Camp Carrol during a $122 \mathrm{~mm}$. rocket attack. On 12 March 1968, shrapnel wound two came from a Rocket Propelled Grenade (RPG) at the Cua-Viet River, where he was hit again for the third time on 28 March 1968 by shrapnel from a Chinese Communist (ChiCom) grenade. On 28 April 1968 , he received his fourth shrapnel wound when the amphibious tractor (Amtrac) he was near was hit by another RPG. Wound number five came on 8 June 1968 from shrapnel resulting from an enemy attack on the Dong-Ha ammunition dump. All of these had been relatively minor wounds in which he was able to remain with his unit. But at 0900 on 28 June 1968, the day before his 33rd birthday, "Gunny" Brandon found himself in a desperate fight for life at the Battle of Dai Do. In an effort to quickly destroy the 3rd Marine Division command post at Dong Ha (the key intersection where Highway One and Route 9 intersected), a reinforced North Vietnamese regiment of the 320th North Vietnamese Division attempted to overrun the understrength 2nd Battalion, 4th Marine Regiment at the town of Dai Do, a mile and a half to the northeast. Here, in a tenacious three-day battle in which the Marine defense stopped the enemy assault, 


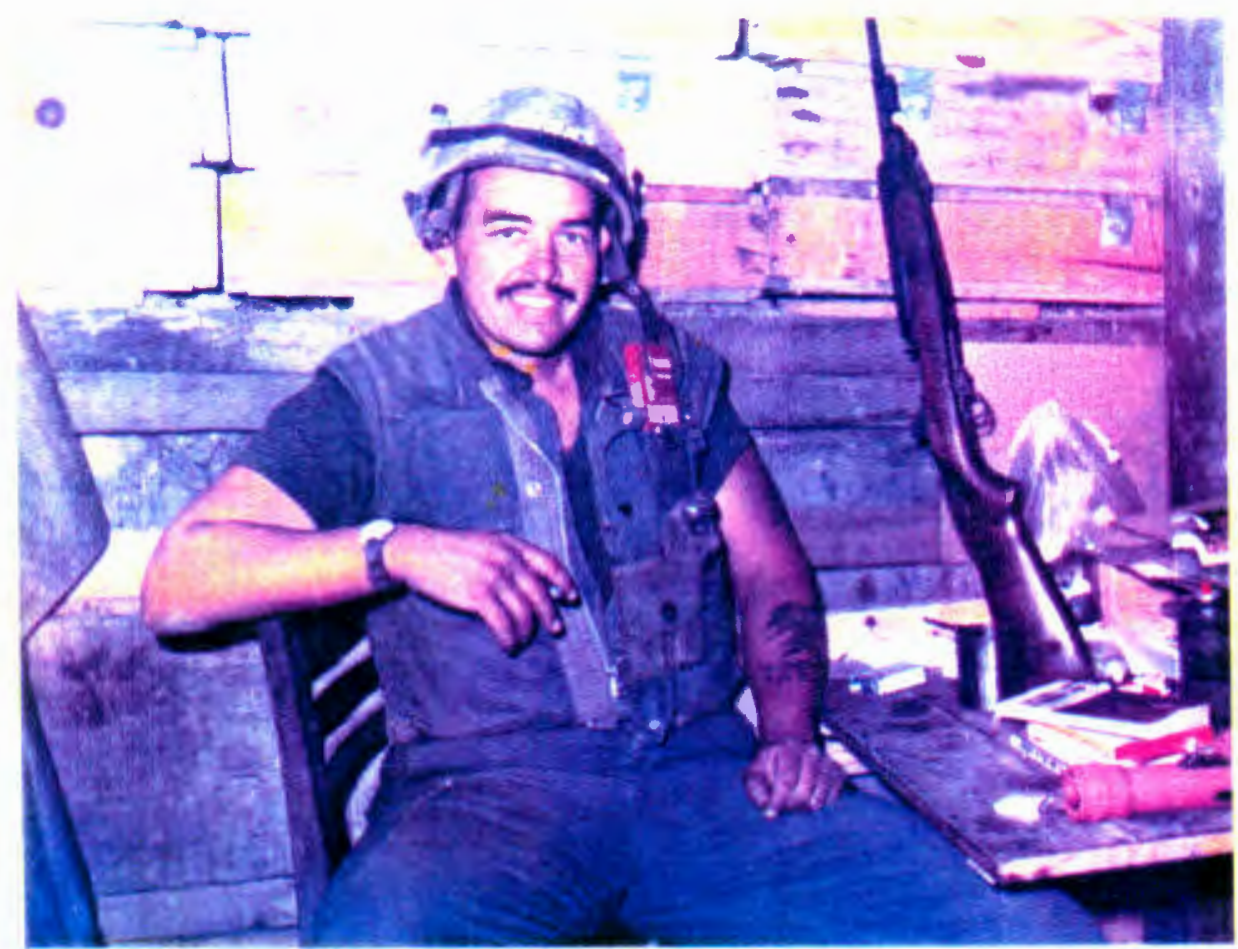

Figure 97: P.E. "Gunny" Brandon of Grande Ronde, while in Vietnam with Company F, 2nd Battalion, 4th Marine Regiment, 3rd Marine Division. He is a Sioux Indian, who holds the dubious Oregon Marine distinction of having earned the most (six) Purple Heart Medals for being wounded in action. His older brother Howard, was killed on Iwo Jima in 1945. The "Gunny" is now retired from the Marine Corps and lives in McMinnville

Photo courtesy of P.E. Brandon Collection 
Captain M. Sando Vargas of Company G (Brandon's company commander) and Captain James E. Livingston of Company E, both earned Medals of Honor. The battalion commander, Lieutenant Colonel William Weise earned the Navy Cross. All three Marine officers were repeatedly hit and seriously wounded, but continued to fight. Brandon was hit for the sixth and final time by shrapnel from both a Claymore mine and a ChiCom grenade, in addition to being shot twice from an AK-47 assault rifle. Evacuated to Danang, he was initially taken for dead and placed in a body bag. He was found in the dead pile and eventually saved through the action of a Marine officer who had monitored the radio in Danang and heard that he'd been wounded. Gunnery Sergeant Brandon eventually recovered from over 43 holes in his tough Sioux hide, and with a Bronze Star Medal and six Purple Heart Medals, retired in 1973 to McMinnville, Oregon. ${ }^{157}$

Back in Portland, Oregon, a solemn change of command ceremony took place on 14 July 1968, when Lieutenant Colonel John F. Williams, Jr., assumed command of 10th Engineer Battalion from Colonel Robert W. Schoning. Colonel Kennedy, Director of the 12th Marine Corps District presided over the ceremony in which Mrs. Terrance L. Meier received the Silver Star Medal and Purple Heart Medal posthumously, on behalf of her husband, Staff Sergeant Meier, who had been killed in action in Vietnam. Also, Mr. and Mrs. Pierce received the Silver Star Medal and Purple Heart Medal posthumously, on behalf of their son, Lance Corporal Merrick R. Pierce, who had also

${ }^{157}$ Moskin, The US Marine Corps Story, p. 667-668, also Personal Interview, between P. E. Brandon and author, Portland, Oregon, 17 April 1994. 
been killed in action in Vietnam. At this same time, the Salem and Eugene units of 10th Engineer Battalion were in the middle of their two weeks of annual training at Camp Pendleton, California, where they conducted an amphibious landing on 15 July 1968 with an estimated 8,000 other Marines. These Marines proceeded with training on Viet Cong village indoctrination and tactics, weapons familiarization and firing, small unit operations, and field engineer projects. Still, there was no activation for Vietnam, even as the 5th Marine Division was stood up at Camp Pendleton (for the first time since World War II) and only partially fleshed out with active duty Marines.

To highlight just how controversial the Vietnam War had become in Oregon (particularly on the campus of the University of Oregon), on a Saturday night in September 1968, militant anti-war protestors using crude explosives and flammable liquids, seriously vandalized a bulldozer and a road grader belonging to the Marine reserve unit in Eugene. The FBI was called in to conduct the investigation.

In 1969, President Nixon stated that "Vietnam has been a profoundly sobering lesson in the limits of U.S. power."158 Remaining in Vietnam was no longer vital to American national interest. When the first American troop contingent left Vietnam in June of 1969 , among them were 8,388 Marines. The pace of withdrawal and "Vietnamization" (turning over responsibilities to the South Vietnamese military) continued until on 25 June 1971, the last Marine ground combat unit left Vietnam. On 30 April 1975, the last Marines from the American Embassy security detachment took

${ }^{158} \underline{\text { Ibid, }}$, p. 673. 
down the American flag and with it, piled onboard the last Marine helicopter to evacuate Saigon. It had been the longest and most frustrating war in American history. The Marine Corps had suffered 14,691 killed and 88,633 wounded. Though Marines represented but $10 \%$ of all American personnel who served in Southeast Asia, one in every four names carved in the Vietnam Memorial, in Washington, D.C., is that of a United States Marine. Vietnam may have represented a failed American foreign policy, but the Marine Corps had not failed America. 


\section{CHAPTER VIII}

\section{GULF WAR TRIUMPH AND THE NEW WORLD ORDER}

"I can't say enough about the two Marine divisions. If I use words like 'brilliant,' it would really be an under-description of the absolutely superb job that they did in breaching the so-called impenetrable barrier. It was a classic, absolutely classic military breaching of a very, very tough minefield, barbed wire, fire trenches-type barrier. They went through the first barrier like it was water. They went across into the second barrier line even though they were under artillery fire at the time. They continued to open that breach. And then they brought both divisions streaming through that breach. [It was an] absolutely superb operation, a textbook, and I think it'll be studied for many, many years to come as the way to do it. "l59

General H. Norman Schwarzkopf US Army, Commander US Central Command Operation Desert Storm, 27 February 1991 Press Briefing, Riyadh, Saudi Arabia

"We have been fully supported by the well trained reserves [of 6th Engineers] who have augmented our battalion. Their rapid and smooth integration has been imperative to the success of 1st Force Service Support Group. ${ }^{1160}$

Lieutenant Colonel D. L. John USMC, Commander 7th Engineer Support Battalion, 1 January 1991, Al Kibrit, Saudi Arabia

${ }^{159}$ H. N. Schwarzkopf, Desert Storm Press Briefing, Riyadh, Saudi Arabia, 27 February 1991, Cable News Network.

${ }^{160} \mathrm{D}$. L. John, 7th ESB Unit Status/Engineer Situation Report, Employment of 6th ESB Personnel, Al Kibrit, Saudi Arabia, 1 January 1991, p. 1-2. 
"Of the 1,200 Marines in our battalion, over 400 were Marine Corps Reservists [of 6th Engineers]. Their ability to immediately step in and perform was critical to the success of the battalion. We could not have accomplished the mission without them, period. They hit the ground running. ${ }^{1161}$

Lieutenant Colonel C. O. Skipper USMC, Commander 8th Engineer Support Bn, Battalion, 12 March 1991, Al Khanjar, Saudi Arabia

As Commandant of the Marine Corps General Robert E. Cushman, Jr. stated in April of 1972, "We are pulling our heads out of the jungle and getting back into the amphibious business." ${ }^{162}$ The one essential trait which has clearly stood out to the American people concerning the Marine Corps, is that it is the armed service that can best project American power onto hostile shores in the most expeditious manner. It was time to get back to the basics and focus on how best to accomplish this mission. That meant reevaluation and reorganization from the top down. It also meant increased importance for the Marine Corps Reserve in the area of readiness. To be meaningful, the Reserve must be able to augment and reinforce its active duty counterparts in a timely and effective manner.

In Oregon, on 2 October 1971, the Marine Reserve engineer battalion headquartered in Portland was combined with the Marine Reserve engineer battalion centered in South Bend, Indiana. This considerably larger unit was now headquartered

${ }^{161}$ C. O. Skipper, 8 th ESB Command Chronology, Enclosure (1), Section B, Deployment, (4) Reserve Support, Al Khanjar, Saudia Arabia, 12 March 1991, p. 5.

${ }^{162}$ Moskin. The U.S. Marine Corps Story, p. 680. 
in Portland and redesignated as the 6th Engineer Battalion. Combining the two commands from the midwest and the west coast eventually resulted in the formation of the largest battalion in the Marine Corps. With an expanded mission and growth, the unit was redesignated again on 31 May 1976 as the 6th Engineer Support Battalion.

The key mission of the Marine Corps Reserve continued to be augmentation and reinforcement of the Fleet Marine Force. For 6th Engineer Support Battalion, this meant thorough emphasis on mobility, countermobility, survivability, and general engineer support. This was the emphasis placed on training throughout the 1970's and 1980's. As one of the Marine Corps' primary Cold War missions was reinforcement of the northern Norwegian flank of the North Atlantic Treaty Organization (NATO), considerable emphasis was placed on reserve cold weather training. Marine Corps wide, a reserve evaluation program known as the Mobilization Operational Readiness Deployment Test (MORDT) was established, which effectively screened units on at least a two year basis. In Oregon, no better example of this preparation for mobilization and combat could be found than Operation Rorkes Drift. This was the name given to the two year preparation done by the 200 Salem and Eugene Marines of Company A for a rarely approved independent company annual training period. This joint annual training evolution from 5 to 19 July 1986, at the Yakima Firing Center in Yakima, Washington, involved reserve Marine engineers, Oregon National Guard infantry, and regular Army tank and mechanized units. The Oregon Marine engineers took the lead in constructing a mechanized assault obstacle course, which was based upon a Soviet company, in-depth 


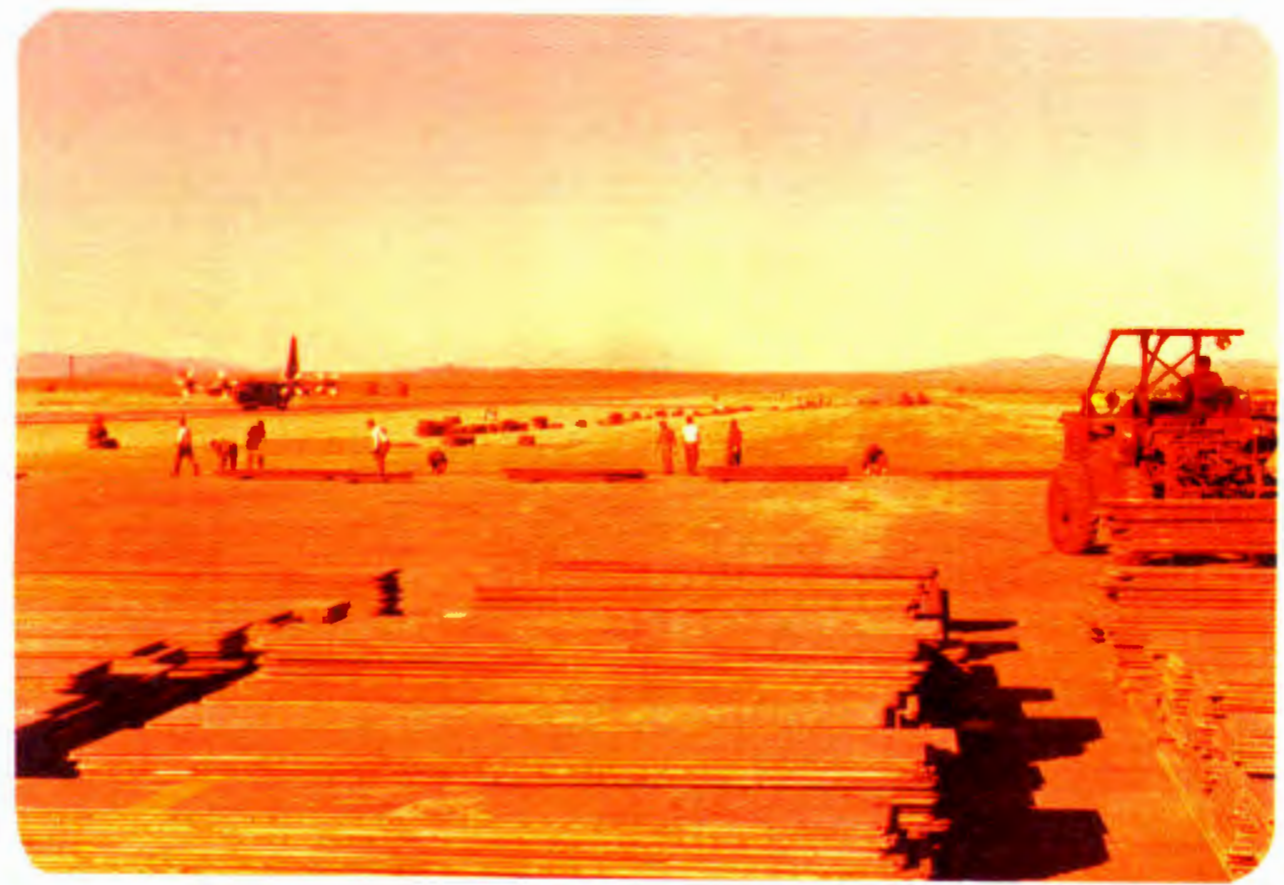

Figure 98: Salem and Eugene Marine engineers are in 1984, the first reserves to participate in repairing the huge Expeditionary Airfield (EAF) at the Marine Corps Air Ground Combat Center, 29 Palms, California. They set a record for laying AM-2 matting, despite average temperatures in June of over 110 degrees.

Photo from author's collection 


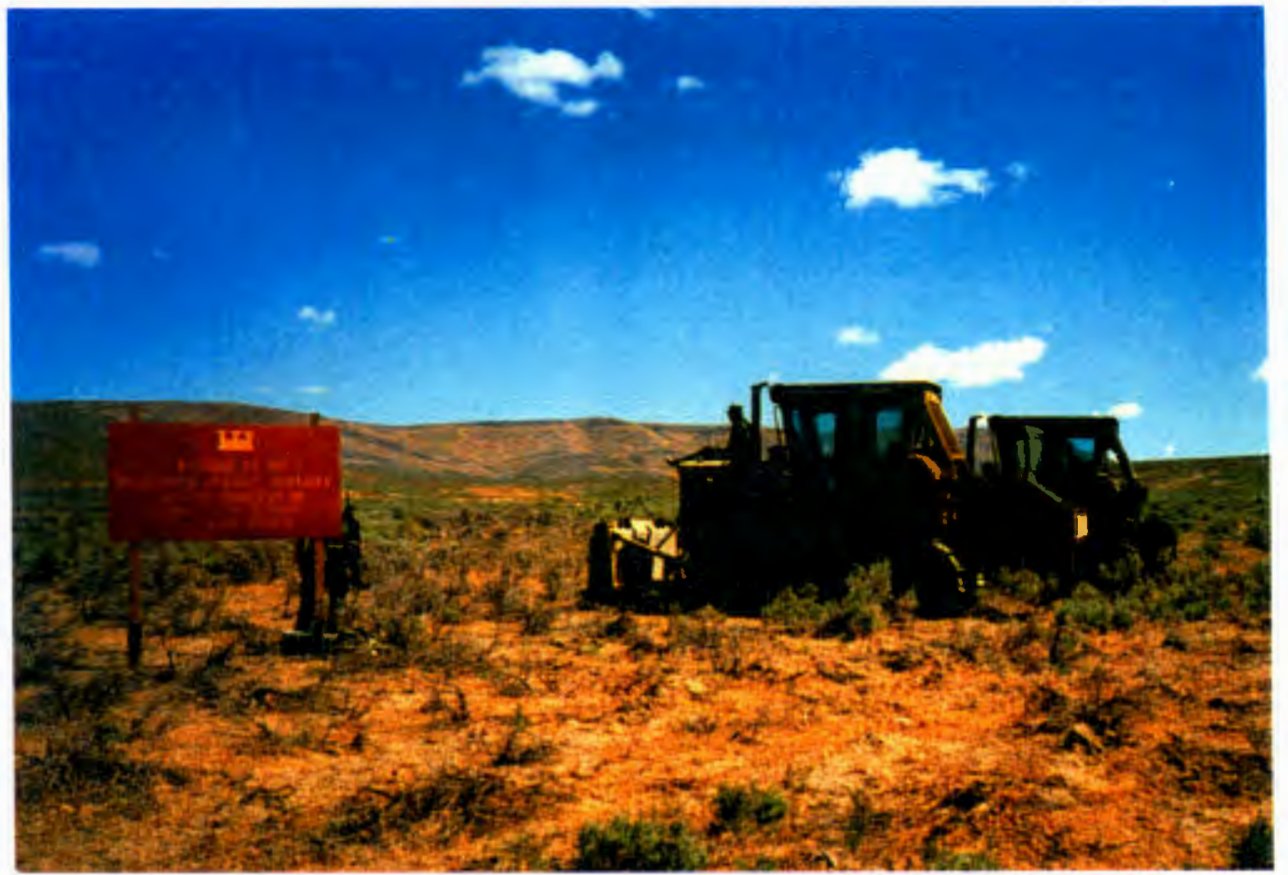

Figure 99: Salem and Eugene Marines conduct 1986 independent annual training at the U.S. Army Firing Center at Yakima, Washington. Here they construct a Mechanized Assault Obstacle Course upon which they conduct mobility, countermobility, and survivability training with a regular Army tank company and a battalion of Oregon National Guard infantry. Many of these same Marines, together with these D-7 bulldozers, will utilize similar tactical breaching techniques in Kuwait during the 1991 Gulf War.

Photo from author's collection 


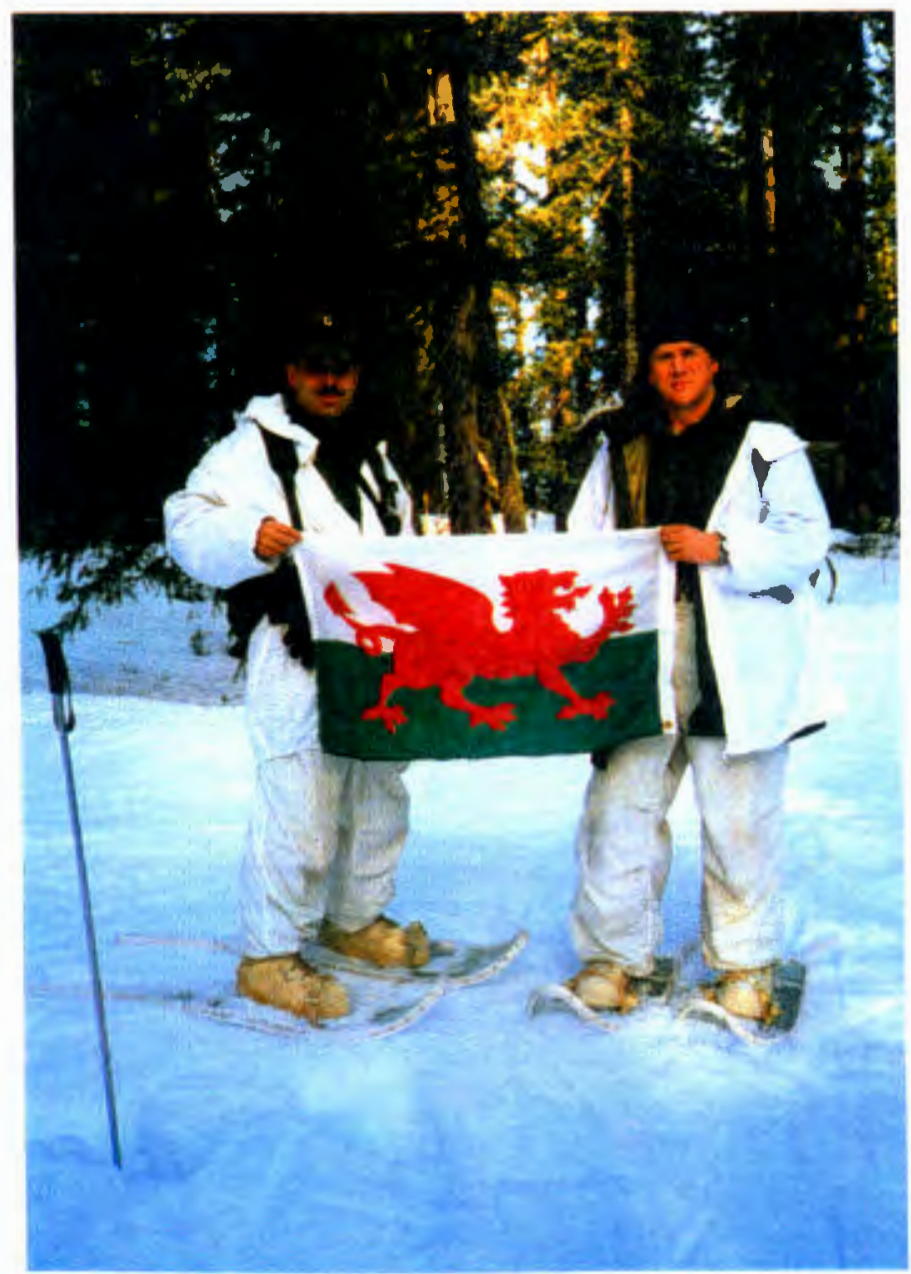

Figure 100: Alfredo J. Arguedas (right), commanding officer of Company A, 6th Engineer Support Battalion (the Salem Marines), and the author, who as a regular captain served as the Salem Inspector-Instructor (advisor). This photo was taken in early 1987 during unit cold weather training near Santiam Pass. The Welsh flag commemorates the past summer's extremely successful Yakima training evolution known as Operation Rorkes Drift (the name was based on an 1879 Zulu War battle in which a Welsh infantry unit commanded by a Royal Engineer held out at 40 to 1). This photo symbolizes the long proven, effective teamwork of Marine Reserves and Regulars working as one "Band of Brothers."

Photo from author's collection 
strongpoint. The Marines then combined with the 1 st/162 Infantry Battalion of the Oregon Army National Guard, based in Forest Grove, Oregon, and Company C, 2nd Battalion, 77th Armored Regiment, from Fort Lewis, Washington. Following a year of classroom doctrinal review, weekend preparatory training, and a series of joint briefings, these units assembled at the Yakima Firing Center. Here they formed a joint combined arms task force, and for the duration of the exercise, implemented various tactics and techniques to assault and breach the series of defended obstacles. This realistic training, which closely patterned that going on at Camp Pendleton and Camp Lejeune by other Marine engineers, was to be of significant importance in their near future.

On 2 August 1990, Saddam Hussein's Iraqi military machine invaded neighboring Kuwait and threatened Saudi Arabia. Most western intelligence sources and the media stated that Iraq possessed the fourth-largest army in the world, while others declared that America had little stomach for a war, especially in the turbulent Middle East. Events soon discredited and disproved both premises, for when this Gulf War ended seven months later, the Iraqi military was "defanged" and America had purged herself of the "ghost" of Vietnam.

On 8 August 1990, President Bush ordered American armed forces to Saudi Arabia and Southwest Asia. By 14 August 1990, the first Marines (of 7th Expeditionary Brigade) had flown in and taken up defensive positions northwest of Al Jubayl, Saudi Arabia. This was to thwart an expected Iraqi attack from the north. On 15 August 1990, the five American ships of the Maritime Prepositioned Ship (MPS) Squadron 2 
arrived at Saudi Arabian ports from the Indian Ocean base at Diego Garcia. By 25 August 1990, the Marines had linked up with this equipment and were ready for combat. They were the first heavy ground combat capability to reinforce Saudi Arabia. The American lead and buildup in what would eventually become a 25 nation allied military coalition (known as Desert Shield), had begun

When Kuwait was invaded, Captain Lundy John Campbell, who was born in Beaverton, Oregon, on 6 January 1961, was stationed as an EA-6B Prowler pilot with VMAQ-2 (Marine Tactical Electronic Warfare Squadron) at Marine Corps Air Station Cherry Point, North Carolina. A graduate of Aloha High School, he had attended the United States Naval Academy at Annapolis as an ocean engineering major. He was commissioned upon graduation into the Marine Corps in May 1984, with a coveted air contract. Following completion of The Basic School in Quantico, Virginia, and a liaison tour with Marine Air Group 41 at Andrews Air Force Base, Washington D.C., Campbell attended flight school at Naval Air Station Pensacola, from July 1985 to May 1986. From here, he took intermediate and advanced jet school at Naval Air Station Kingsville, Texas, flying T-2 Buckeyes and A-4 Skyhawks. In August 1987, he moved on to specialized EA-GB training at Naval Air Station Whidbey Island, Washington. In June 1988, Campbell received those much awaited orders to his first operational squadron: VMAQ-2, where he did carrier work ups for a deployment to Marine Corps Air Station Iwakuni, Japan, from May to November 1989. On 27 August 1990, Campbell, together with his squadron of twelve aircraft (and fourteen aircrews totaling 60 officers and 180 

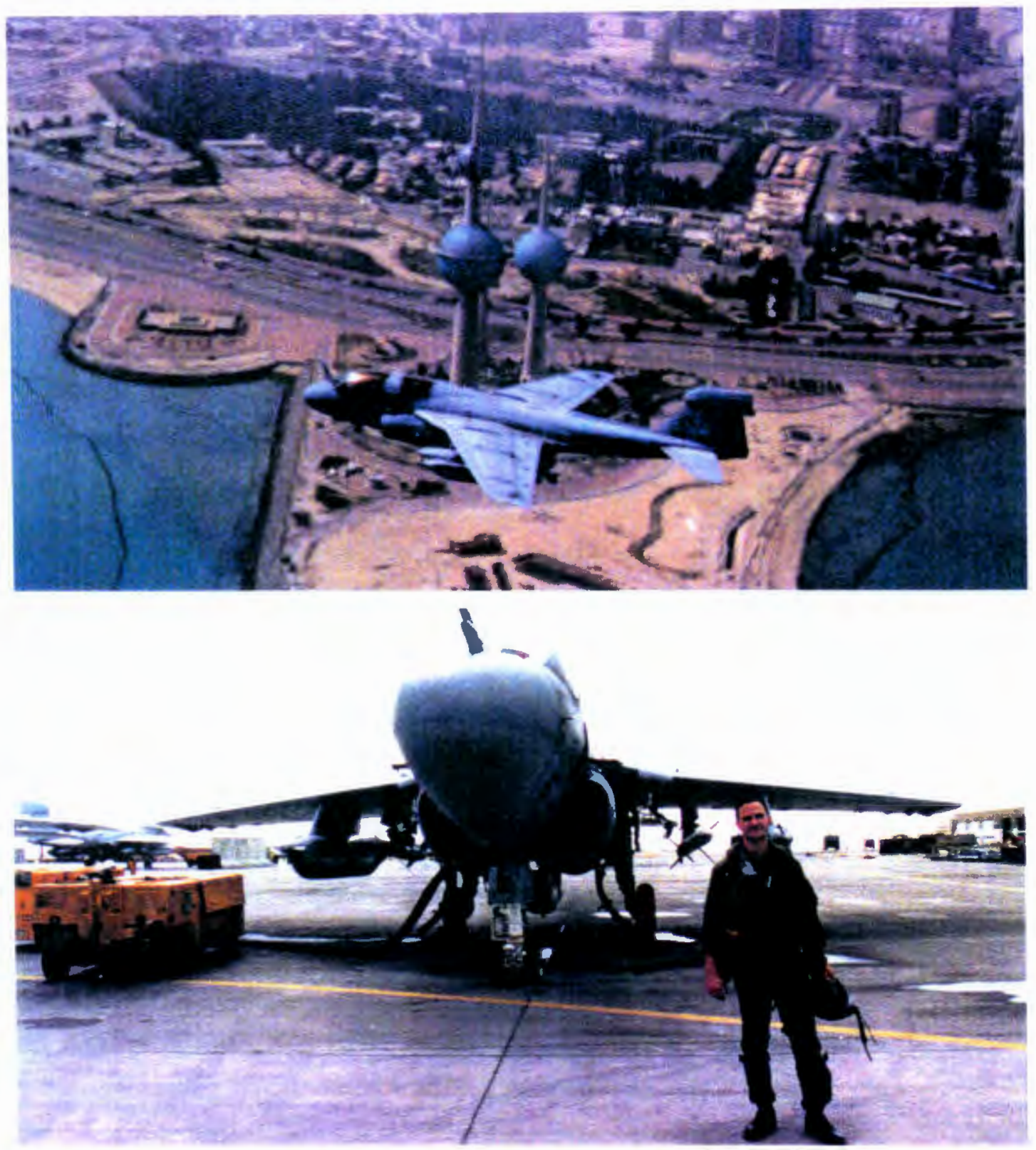

Figure 101: Marine EA-6B Prowler jet aircraft of VMAQ-2 (Marine tactical electronic warfare squadron) over Iraqi occupied Kuwait City, January 1991.

Figure 102: Lundy J. Campbell of Beaverton, in front of his EA-6B Prowler of VMAQ-2 following his 34th and final combat mission during the 1991 Gulf War. He would later serve as the assistant operations officer for 6 th Engineer Support Battalion in Portland.

Photos courtesy of Lundy L Campbell Collection 
Marines), found themselves expeditiously deploying from Cherry Point, North Carolina, via Rota, Spain, to Bahrain, in Southwest Asia. Within two days, the squadron was making its first patrols flying along the Saudi Arabian, Kuwait, Iraqi border.

Their average mission consisted of electronic surveillance alongside combat air patrols of F-18 Hornets, at 350 knots $(450 \mathrm{mph})$ and $20,000 \mathrm{ft}$ altitude. This kept them well above Iraqi AM "Triple A" (Anti Aircraft Artillery) ranged five to ten miles south of the border

At 000117 January 1991, "H-hour" signaled the start of the Desert Storm air war against Iraq. For the three days prior to this, Captain Campbell and his squadron had practiced mirror image rehearsals of their designated strike packages over the Nefud Desert of Saudi Arabia. For the first four days of the war, most of their missions were focused against the Basra region of southern Iraq, flying electronic countermeasure escort for Marine F-18s and A-6s using 1,000 pound Mark 86 bombs to blow bridges across the Tigris and Euphrates Rivers. Within the first three to four days, the Iraqi surface to air missile defense capability was shut down very effectively. Another primary target was to eliminate the Iraqi Airbase at Tallil. Following this, targets were shifted to Iraqi Republican Guard unit and other troop concentrations in occupied Kuwait. At 0900 on 28 February 1991, the cease fire order was given, with Captain Campbell having accumulated a total of 34 missions. He would later receive the Air Medal for his first mission, in which his aircraft was engaged by not only Iraqi surface to air missiles, but also Iranian anti-aircraft units employing old American Hawk missiles. Both were 
successfully dealt with using both electronic countermeasures and HARM (homing allweather radar missile) missiles. On 21 April 1991, Captain Campbell returned with his squadron to Cherry Point, North Carolina. By May of 1992, he had transferred to the reserve in Portland, Oregon, where he served as the assistant operations officer for 6th Engineer Support Battalion, while focusing on marriage and medical school ${ }^{163}$

Another Oregon Marine aviator also suddenly found himself deploying to Southwest Asia. This on 28 August 1990 (a day after Captain Campbell). Captain Michael Vincent Barnes was born on 3 December 1957, in Portland. Having attended Central Catholic High School, he received a Bachelor of Science degree in safety from Oregon State University, where he spent four years in the Naval Reserve officer Training Course (NR0TC) earning an air contract. He graduated and received his commission in Corvallis on 1 June 1980. Following The Basic School (TBS), Barnes immediately attended flight school in Pensacola from February 1981 to March 1982. In the endearing terms of ground Marines for their fellow aviators, Barnes was destined, unlike Campbell who was a "bugsucker" (fixed wing jets) to become a rotorhead (helicopters). From April 1982 to July 1988, he not only attended as a student, but later returned as an instructor to HMT-301 and 302 (Helicopter Marine Training Squadrons) in Tustin, California. An interim tour from January 1983 to December 1985 was spent with HMH361 (Helicopter Marine Heavy), flying CH-53 A and D model Sea Stallions. Since July

${ }^{163}$ Personal Interview between L. J. Campbell and author, Portland, Oregon, 1 August 1994. 


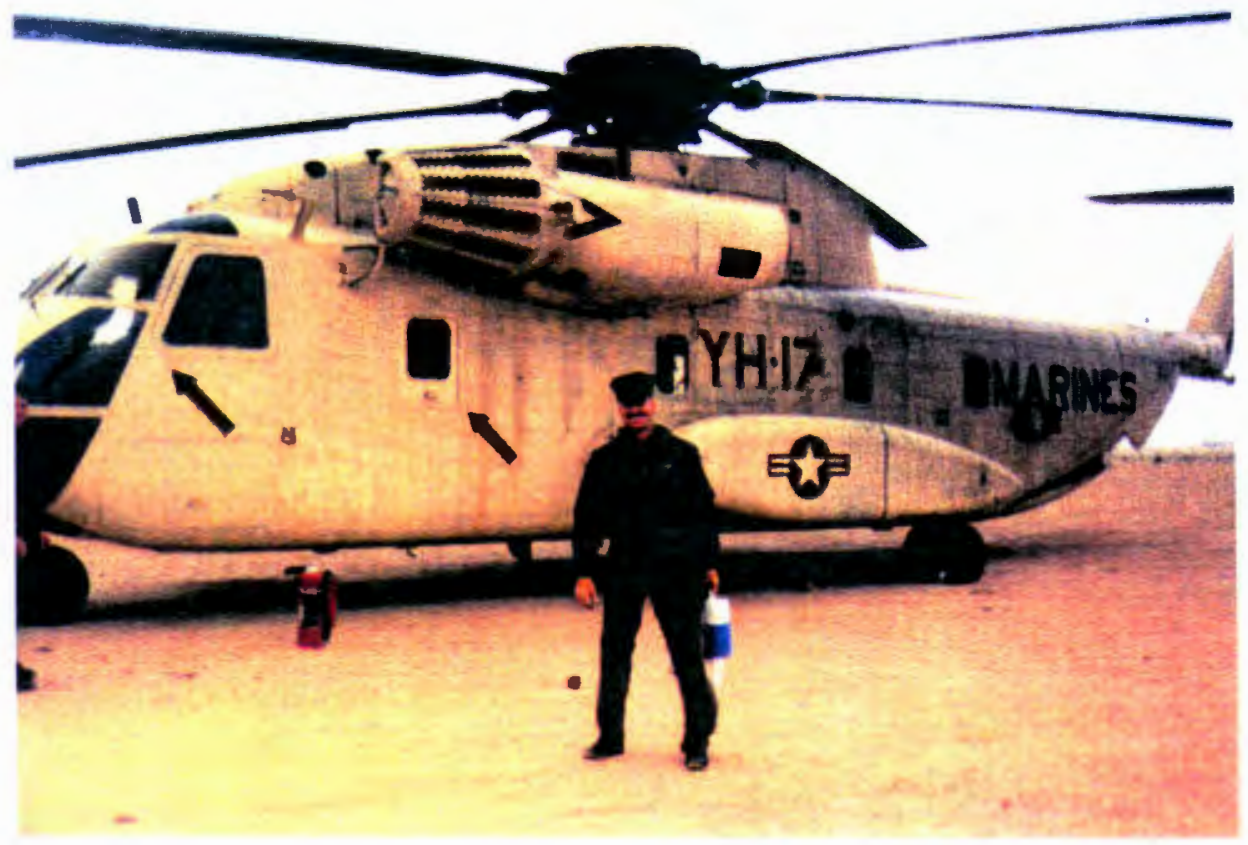

Figure 103: Michael V. Barnes of Portland, a Marine CH-53 Sea Stallion helicopter pilot during the Gulf War. This picture was taken in January 1991 at Ras Safayina, Saudi Arabia just prior to the start of the ground war. He was transporting Marine Lieutenant General Boomer (senior Marine in Gulf) to a planning conference. Barnes would later serve as the 6th Engineer Support Battalion adjutant in Portland

Photo courtesy of Michael $\underline{V}$. Barnes Collection 
1988, he had been stationed with HMH463 at Marine Corps Air Station Kaneohe Bay, Hawaii. Deployment to the Persian Gulf found the eight CH-53 D's of HMH-463 being shipped out two per C-5A Galaxy transport aircraft, while the squadron's 22 officers and 180 Marines followed in trace. Following their arrival at Al Jubayl Airfield (which they shared with 4 Saudi Arabian Pumas and 96 other USMO helicopters), the first HMH-463 missions were conducted within 48 hours. These consisted primarily of cargo resupply, troop movement, and medical evacuation flights at about 130 knots $(150 \mathrm{mph})$ and altitudes ranging from 25 to 200 feet. By mid-October 1990, amid the continued American build-up, HMH-463 had dispersed to the less congested Ras Al Gar Airfield. On 14 February 1991 his squadron placed the first American ground troops on Kuwait soil when they landed on and occupied a small offshore island. These same types of troop movement and resupply missions continued through the air and ground war phases of Operation Desert Sword, with the major concern being Iraqi anti-aircraft artillery fire. Captain Barnes and his squadron were the first to place troops into the Al Jaber Airfield in Kuwait, this while receiving Iraqi artillery fire. Following the conclusion of the Gulf War, he and his unit returned on 17 March 1991 to Kaneohe Bay, Hawaii, aboard a Hawaiian Airline L-1011. Captain Barnes later transferred to the Marine Corps Reserve and by November of 1992, joined 6th Engineer Support Battalion as its 
Adjutant. In his civilian occupation, he now works for the Postal Department in Portland. ${ }^{164}$

On 8 November, President Bush announced a significant reinforcement of the then 230,000 American troops in Southwest Asia (this force eventually peaked at $540,000)$. Included was the first major Presidential call-up of American reserve forces since the Korean War. America clearly "expanded its options" by creating a force with strong offensive capabilities in Saudi Arabia. This action had a direct impact on Oregon, in that the 6th Engineer Support Battalion units at Portland, Salem, and Eugene, were partially activated. Most of the battalion's other units across the United States were similarly activated. The battalion now had cause to demonstrate its motto: "We are Ready."

A total of 175 Oregon Marines, following in the footsteps of their reserve forefathers activated in 1940 for World War II, and in 1950 for the Korean War, were soon activated for Operation Desert Shield and on their way to the Persian Gulf. For this and the eventual invasion of Kuwait (Operation Desert Storm), the "Portland Marines" found themselves serving with and supporting 1st Marine Division while the "Salem and Eugene Marines" would be with 2nd Marine Division.

\footnotetext{
${ }^{164}$ Personal Interview between M. V. Barnes and author, Portland, Oregon, 2 September 1994.
} 
The "Portland Marines" of Combat Engineer/Construction Platoon, Headquarters and Services Company, 6th Engineer Support Battalion, received their call-up message on 28 November $1990 .{ }^{165}$

Under the command of Warrant Officer Bill Hobbs, and with the senior enlisted support of Staff Sergeant Robert Putnam, the platoon flew out of Portland early on the morning of 10 December 1990, for San Diego, California. They remained at Camp Pendleton for four weeks of combat refresher training with particular emphasis being placed on mine warfare and nuclear, biological and chemical defense training. The platoon of "Portland Marines" was on 7 January 1991, bussed to Norton Air Force Base, where it boarded a C-141 transport for the long flight to Frankfurt, Germany, and on to the Persian Gulf.

As Corporal Eric Gerow later stated, the unit experienced "a panoramic view and a sense of unease" 166 as it landed at Al Jubayl, Saudi Arabia on 8 January 1991. Four days later the unit moved 125 miles north, first to the assembly area or Al Mish'ab, and then inland to the main Marine forward staging area and logistic base known as Al Kibrit Live ammunition was immediately issued to all Marines.

Marines at Al Kibrit were front seat spectators to the U.S./Allied air offensive commencing on 17 January 1991, and to the exchanging duels between Iraqi Scud and

${ }^{165}$ Ibid., p. 1.

${ }^{166}$ Personal Interview between E. B. Gerow, H\&S Company, ESB Combat Engineer NCO and author, Portland, Oregon, 26 September 1991, 6th ESB Historian Notes, After Action, p. 32. 


\section{ene Etregoman}

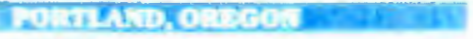
The U.N. vole b" "a strang and powertul measege. $t$ with go around the morld loud and clever that this gur's got to get out of there."

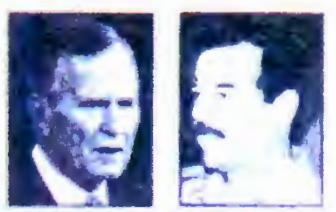

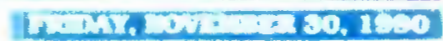

"The Americans are str D.P influenced by Rimbo movies

but this is not a Rambo

movit. This is something differencen

\section{U.N. sanctions use of force if Iraqis don't leave Kuwait}

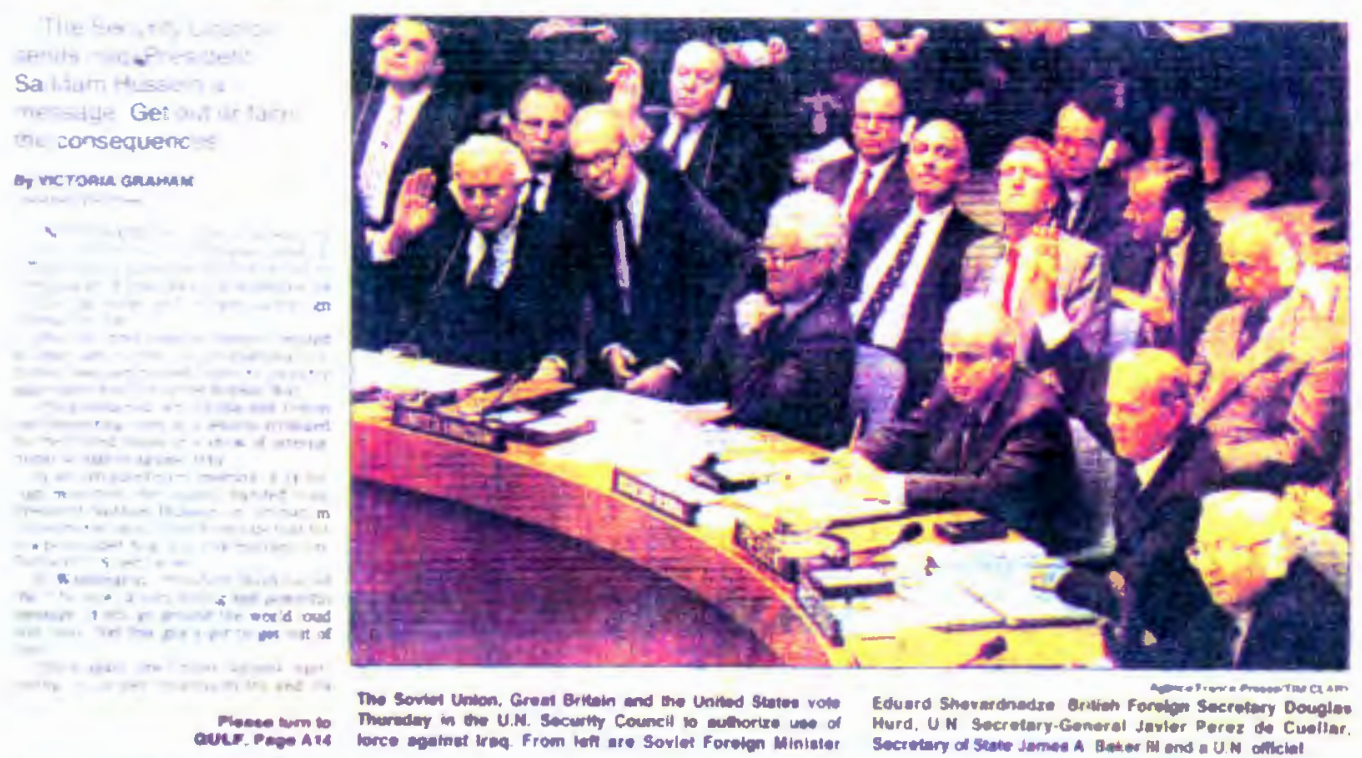

FRONT PAGE OF

30 NOVEMBER 1990

OREGONIAN - FIRST

OREGON MARINES ACTIVATED

SINCE KOREAN WAR
Local Marine reservists called to active duty
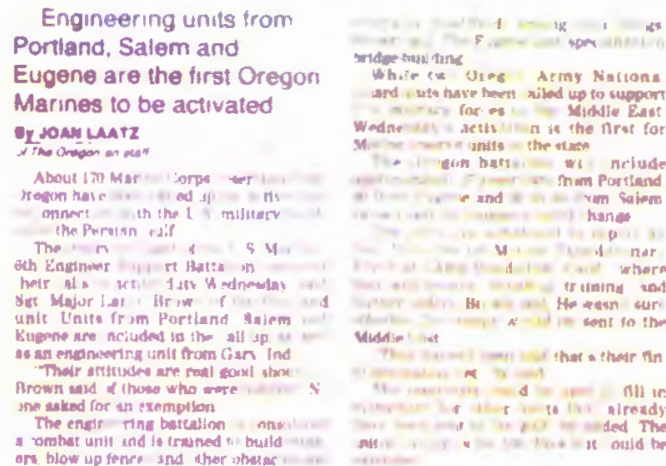

Figure 104: 30 November 1990 front page of The Oregonian 
American Patriot missiles. The sound of Allied bombs impacting to the north continued around the clock. At Al Kibrit, the "Portland Marine" platoon focused for almost a month on constructing defensive positions, stringing concertina wire, guard duty, mine warfare classes, and general engineer support operations

Redesignated as 3rd Platoon, Company C, 7th Engineer Support Battalion, the "Portland Marines" were a part of the 1st Force Service Support Group providing full logistic capability to the 1st Marine Division. As combat engineers, these Marines also understood that their mission would include providing depth to the assault breaching effort of the 1st Combat Engineer Battalion of 1st Marine Division. Major emphasis was placed on combat engineer assault breach training so as to neutralize Iraqi minefields and other obstacles in Kuwait. The arrival of D-7 bulldozers with mine rakes and armored protection kits, together with rocket propelled explosive line charges added emphasis to this training.

Staff Sergeant Robert Putnam (who earned the Navy Achievement Medal during Operation Desert Storm) stated: "As the platoon neared the minefields of Kuwait, they were told that they would be combat replacements for those clearing the minefield obstructions. As the anticipated losses were expected to be near $10 \%$ in the first few days, we knew we would be relying on our minefield and demolition training, as well as infantry tactics, to accomplish the mission and stay alive." ${ }^{167}$

${ }^{167}$ Personal Interview between R. E. Putnam, 6th ESB Platoon Sergeant, and author, Portland, Oregon, 6 October 1991, 6th ESB Historian Notes, After Action, p. 36. 


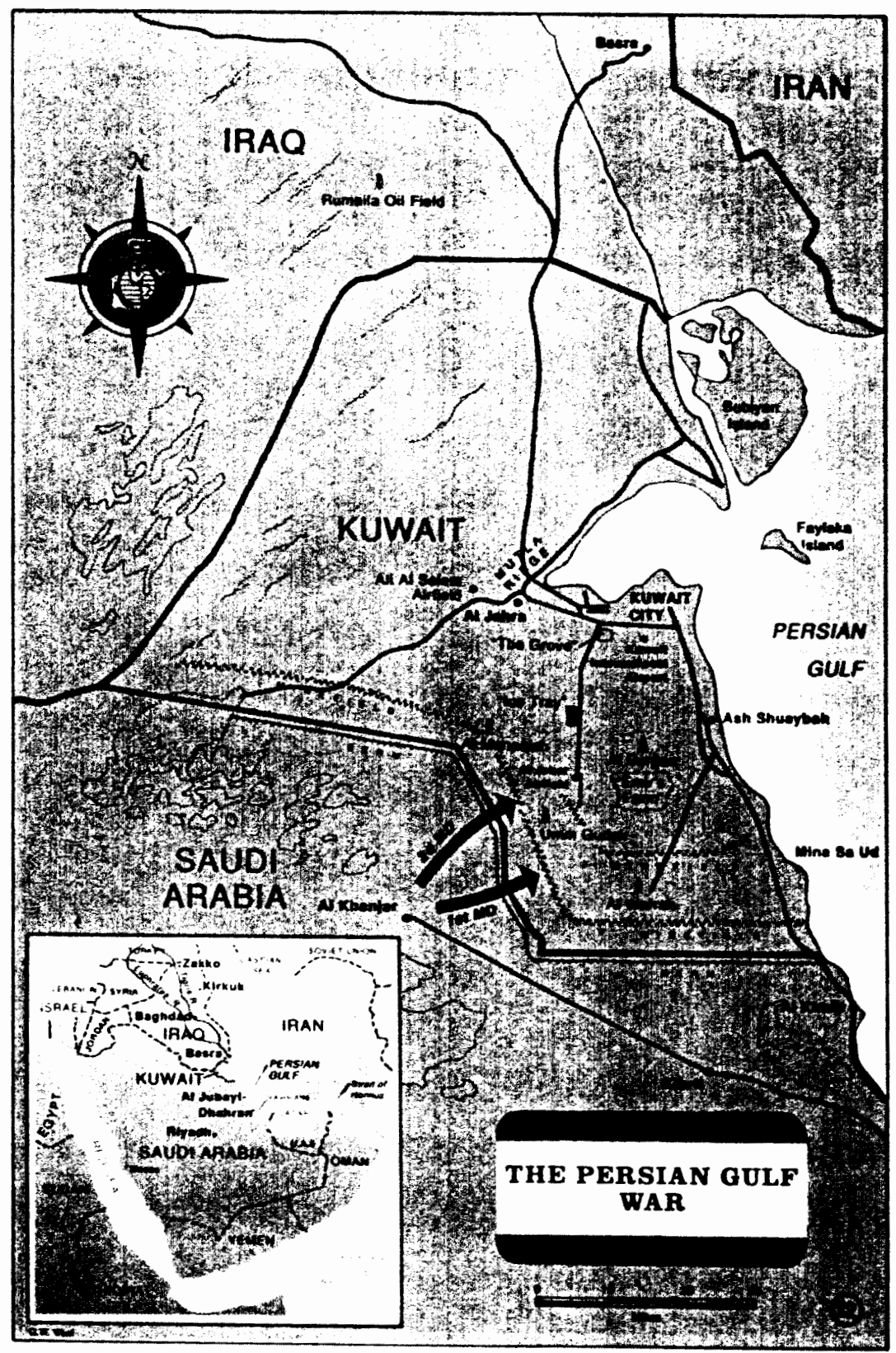

Figure 105 Map of Kuwait showing area where 1st and 2nd Marine Divisions participated in Operation Desert Storm, February 1991

The US Marine Corps Story by J Robert Moskin. 3rd Revised Edition, Little. Brown and Company, Boston, 1992, Map \#12, p. 20 
On 11 February 1991, the unit rapidly displaced to Al Rhanjar, 70 miles to the northwest and roughly 15 miles southwest of occupied Kuwait's closest border. This was part of the overall shift of both 1st and 2nd Marine Divisions into their final offensive posture. The "Portland Marine" engineers commenced this same day in constructing a 340 bed field hospital for Combat Service Support Detachment 10's medical unit. As Corporal Trent Waibel noted in his journal of 18 February: "Worked on strongbacks (raised lumber frame with tent covering structure), setting a record day by finishing off three, and then from scratch building five more. For twelve Marines, that's pretty good." 168 On 19 February 1991, thirty-eight general purpose tent "strongbacks" were rapidly completed and turned over to 1st and 2nd Medical Battalions. A strong sense of urgency had prevailed throughout, as this hospital was expected to handle the initial inflow of an estimated ten thousand U.S. casualties within the first forty-eight hours of the ground war. ${ }^{169}$ This was also the day that the Marines were briefed on the upcoming "G-Day" or ground offensive day. ${ }^{170}$

On 20 February, the "Portland Marines" packed their equipment and moved up with 7th Engineer Support Battalion behind the 1st Marine Division. This was approximately 20 miles northeast to Outpost 4 , just within the Kuwait border. The

\footnotetext{
${ }^{168}$ T. R. Waibel, H\&S Company, 6th ESB, Combat Engineer NCO, Personal Journal From the Persian Gulf War, (Oregon, California, SW Asia, 26 November 1990 to 9 April 1991), p. 20.

${ }^{169}$ Personal Interview, Gerow, p. 32.

${ }^{170}$ Waibel, Personal Journal, p. 9.
} 

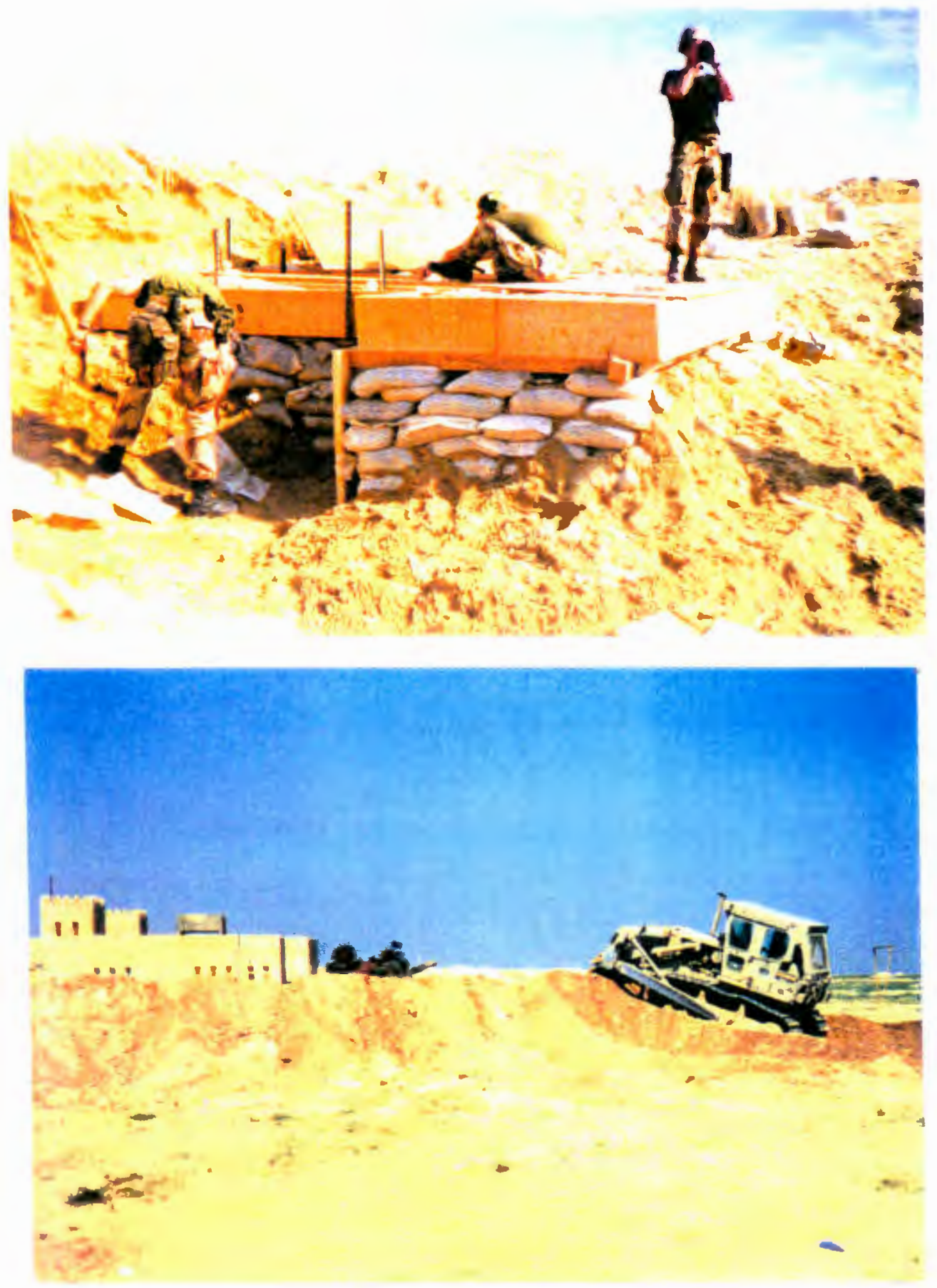

Figure 106 and 107: Portland Marines conduct bunker construction at Al Khanjar, Saudi Arabia on Kuwait border. The second photo shows Oregon Marines breaching anti-tank berms in Kuwait, February 1991.

Author's collection 
outpost consisted of some buildings and an abandoned police station. The Marines dug foxholes behind an anti-tank berm to live in while awaiting the opening of the ground offensive. The night skies were illuminated with the continuous bombing of Iraqi positions. As Corporal Gerow stated: "This was a real confidence builder and was great for morale."171

On 22 February, with the weather cold and rainy, detailed briefings were given concerning the plans for the breaching of the two Iraqi minefields, seven miles apart within the Kuwaiti border. This breaching operation was the responsibility of 1 st Combat Engineer Battalion, backed by 7th Engineer Support Battalion (with the "Portland Marines"). Individual Marines were instructed to begin taking their nuclear, biological, and chemical defense agent and Anthrax pills. ${ }^{172}$

The following day marked "G minus 1 Day," the last day prior to the offensive. All Marines did their final equipment checks as they watched the lead assault units of 1 st Marine Division's "Task Force Papa Bear" move up to their jump-off positions.

"G-Day," commenced officially at 0400 on Sunday, 24 February 1991. The launching of the American/Allied ground war began with a 50\% alert for the "Portland Marines" of 7th Engineer Support Battalion. Isolated incoming Iraqi artillery fire occurred causing some Marine casualties. Heightened security continued through the next day as Marines monitored radios and passed on the latest "scuttlebutt" as lst Marine

\footnotetext{
${ }^{171}$ Personal Interview, Gerow, p. 32.

${ }^{172} \underline{\text { Ibid. }}$, p. 32.
} 


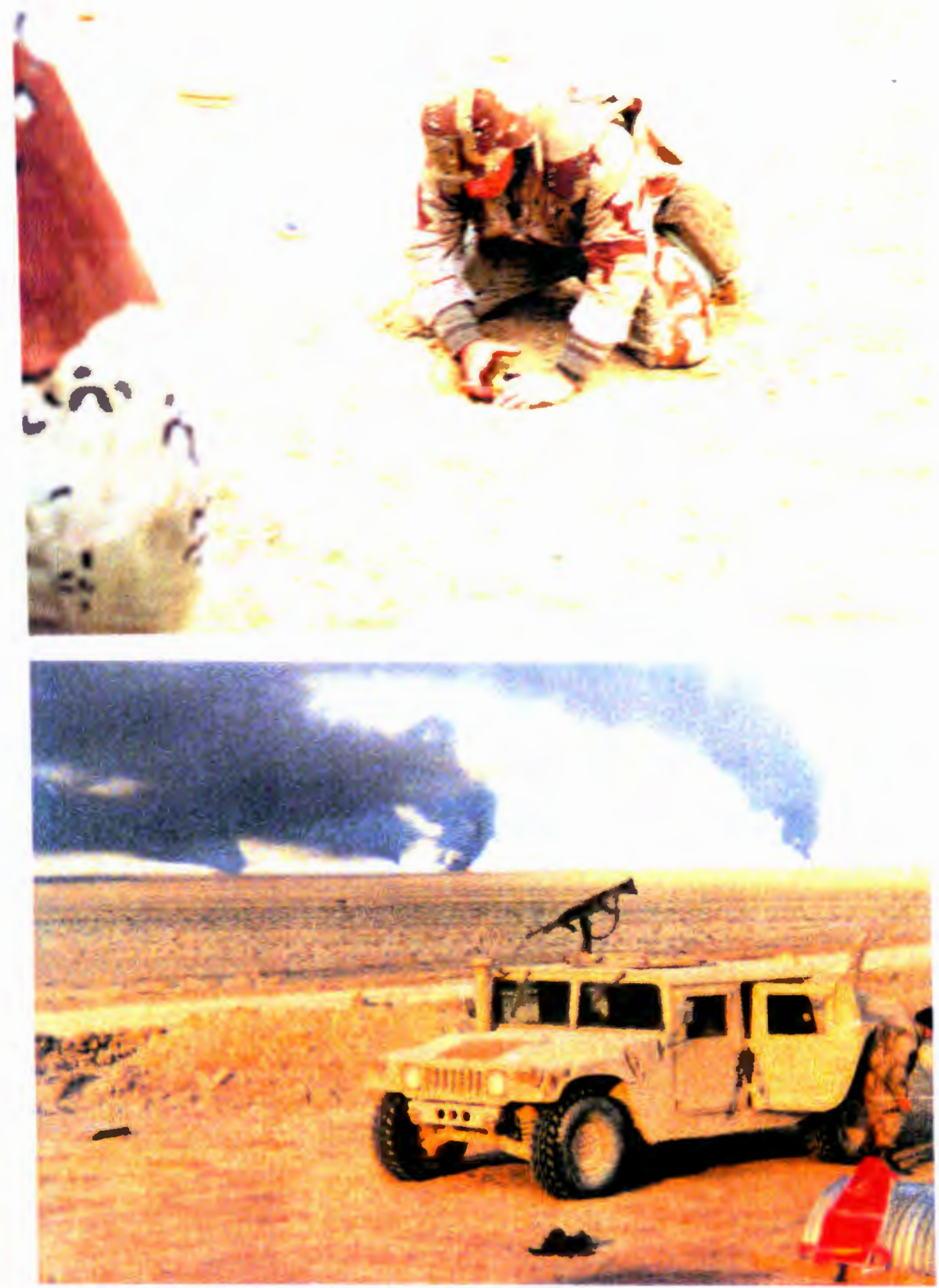

Figure 108 and 109: An Oregon Marine disarming an Iraqi landmine (an Italian Valsella "toe-popper") inside Kuwait. Second photo is of Portland Marines stopped at a Ist Marine Division checkpoint near burning Al Wafrah oilfield in Kuwait, February 1991.

Author's collection 
Division surged forward between the $\mathrm{Al}$ Wafrah and Umm Gudair oil fields, with $\mathrm{Al}$ Jaber Airfield and Kuwait International Airport as its primary objectives. Positive reports of rapid American and Allied advances and the capture of large numbers of Iraqi prisoners were received. It was at this time, that Sergeant Troy Lackey, of Portland, earned the combat Action Ribbon for volunteering to participate in, and successfully conducting, a minefield reconnaissance at an Iraqi barrier. ${ }^{173}$

On 26 February, the "Portland Marine" platoon moved up to the first breached Iraqi minefield and was instructed to widen the existing passage. Here, the professional initiative and weeks of detailed in-house platoon classes on the part of Sergeants Stephen A. Waterman, David L. Fraser, and Troy Lackey (all of greater Portland) paid off. These Marines had focused platoon training on the operating characteristics and removal procedures of Warsaw Pact and NATO landmines. Soviet, Italian, and even British mines were encountered and successfully handled. Combat engineer work continued as the initial breaches were widened to permit the passage of additional logistic vehicles on what was now the main supply route of 1 st Marine Division. This actual process consisted of the engineers ensuring that the mines were not "booby-trapped", switching the fuses from "armed" to "safe", and then removing the mines a short distance to where they were destroyed.

${ }^{173}$ Personal Interview between W. R. Hobbs, 6th ESB Platoon Commander and author, Portland, Oregon, 9 September 1991, 6th ESB Historian Notes, After Action, p. 5 . 
On 28 February 1991, the "Portland Marines" received word of the official cease fire. The platoon pulled back with the battalion to Al Rhanjar, where it awaited implementation of a general withdrawal plan. On 2 March 1991, a memorial service was held for the one Marine from 7th Engineer Support Battalion who had been killed in action as a result of Iraqi artillery fire. ${ }^{174}$

After "breaking down" the Al Khanjar camp by 7 March 1991, the "Portland Marines," together with the rest of their battalion, moved back to the port of Al Jubayl. Like most Marines in Saudi Arabia, the period following the Gulf War was occupied with the endless cycle of washing down gear, embarking equipment and standing guard duty. The "Portland Marine" platoon boarded its TWA 747 aircraft early on 9 April 1991 and departed Saudi Arabia, arriving back in California on the same day. At Camp Pendleton, the platoon conducted it final out processing and following a string of parties, bid farewell to 7th Engineer Support Battalion and 1st Marine Division.

On 1 May 1991, the "Portland Marines" of Combat Engineer/Construction Platoon, Headquarters and Services Company, 6th Engineer Support Battalion, returned home to Oregon. Here it was heartily greeted by hundreds of family, fellow Marines, well-wishers and the media. Also present was an Oregon Army National Guard band which played "The Marines' Hymn." The platoon was officially deactivated on 5 May 1991, and returned to reserve status.

${ }^{174}$ Waibel, Personal Journal, p. 9. 
While the "Portland Marine" platoon from 6th Engineer Support Battalion shared its Gulf War experience with the 1st Marine Division, events dictated that both the "Salem and Eugene Marine" companies of 6th Engineer Support Battalion worked in support of the 2nd Marine Division. The messages activating the "Eugene Marines" of 6th Bridge Company and "Salem Marines" of Company A, were received respectively on 27 November and 4 December 1990. The actual mobilization date (8 December 1990) and interim destination (Camp Pendleton, California) were the same for both units. ${ }^{175}$ The "Eugene Marines" mobilization plan simply called for two officers and seventy-seven enlisted Marines to report to Camp Pendleton, California. The "Salem Marines" activation was more complex in that it called for three officers and sixty-three enlisted Marines to divide and report to two different commands and locations. The first group, consisting of one officer, Captain Rod Pray, and fourteen Marines, reported to Combat Service Support Detachment (CSSD) 41 at the Marine Corps Air Ground Combat Center, 29 Palms, California. Here they replaced the previously deployed CSSD 12, and assumed the mission of supporting the Desert Training Program for other Marine units bound for the Persian Gulf. The second group, two officers and forty-nine marines, reported to the 1st Force Service Support Group (FSSG) at Camp Pendleton, California. This group was under the command of Major Wes Howe, with Gunnery Sergeant Lester Huntainger serving as the senior enlisted man.

${ }^{175}$ Personal Interview between T. E. Starr, 6th Bridge Company I\&I and James Gladbach, Company A, 6th ESB, I\&I Salem and author, Portland-Eugene-Salem, Oregon, 12 \& 17 September 1991, 6th ESB Historian Notes, After Action, p. 7 \& 12. 
A considerable amount of Oregon Marine heavy equipment, ranging from bulldozers, trucks and cranes, to welding and floodlight units, were also included. ${ }^{176}$

Upon their arrival at Camp Pendleton, it was directed that the "Oregonian Marines" of Company A (Salem) and 6th Bridge Company (Eugene), combine to form one large Company A, to be referred to as 6th Engineer Support Battalion (Forward). It was believed at the time, that the rest of 6th Engineer Support Battalion would soon be following. With this organization temporarily under the command of Major Frank Beleskie (Engineer Support Company, 6th ESB, Gary, Indiana), and Major Howe serving as the executive officer, Captain Bill Hatton (commanding officer, 6th Bridge Company, Eugene, Oregon) took command of Company A, the combined unit of "Salem and Eugene Marines."

After receiving the standard combat refresher training package at Camp Pendleton, Company A was airlifted to the Persian Gulf on 8 January 1991. Arriving in Al Jubayl, the unit was assigned to 2nd Force Service Support Group, 2nd Marine Division, where it reinforced the understrength 8th Engineer Support Battalion. So as not to be confused with the battalion's original Company A, the "Salem and Eugene Marines" were redesignated as Company D, 8th Engineer Support Battalion.

8th Engineer Support Battalion, in preparation for its planned support of 2nd Marine Division, began the extensive movement of Marines and heavy equipment north to the huge logistic base known as Al Kibrit.

${ }^{176}$ Ibid., p. 7. 
On 12 January 1991, the "Salem and Eugene Marines" commenced work on the joint hospital project at Al Kibrit. Much like their other Marine engineer counterparts in Saudi Arabia, the days and nights were filled with security guard duty, brief pauses for food and sleep, and continuous construction projects. These included tent structures, bunkers, trenchlines, ammunition storage points, landing zones, shower facilities, medical facilities and the ever-present combat trail, road construction and main supply route improvements.

By 8 February 1991, 8th Engineer Support Battalion joined in the massive shift further northwest to Al Thanjar, coinciding with the overall American ground offensive strategy. On 19 February, the "Salem and Eugene Marines" of Captain Hatton's Company D, 8th Engineers, were sent to participate in the construction of the main supply route (MSR) for both 1st and 2nd Marine Divisions. Known as the "Knanjar Expressway", it ran from Al Khanjar north to the Saudi Arabia-Kuwait border. The staging areas at the end of this road were the planned "kick-off" points for both the 1st and 2nd Marine Divisions on "G-Day" (ground offensive day). Two major field hospitals, designated as Fox and Golf, added a sobering sense of urgency and determination to the efforts of the Marines. The huge scope and massive scale of the two logistic camps at both Al Kibrit and Al Khanjar dwarfed all previous combat support and combat service support efforts in Marine Corps history. ${ }^{177}$

${ }^{177}$ C. C. Krulak, "CSS in the Desert," Marine Corps Gazette, October 1991, p. 
When the ground war began, 8th Engineer Support Battalion's "Task Force Dozer" was assigned to the breaching force of the forward assault elements of 2nd Marine Division. These combat engineers successfully cleared mines and recovered damaged vehicles from the main Iraqi minefield in the Umm Gudair area of Kuwait. They continued to improve the overall trafficability of the main supply routes leading from Saudi Arabia into Kuwait amid light Iraqi artillery fire. By early afternoon, 2nd Combat Engineer Battalion moved forward with this engineer company from 8th Engineer Support Battalion and began breaching work on the second major Iraqi minefield belt within Kuwait.

While this occurred, Lieutenant Colonel Skipper, the commanding officer of 8th Engineer Support Battalion, moved Company C, and Company D (the "Salem and Eugene Marines") into position to widen the hazardous 10 to 16 meter single lane minefield breach into a safer double lane width of 50 meters. ${ }^{178}$ The "Salem and Eugene Marines" then proceeded to improve and repair four miles of four lane road for the continuing of the "Khanjar Expressway". This contributed toward the vast array of 2nd Marine Division support vehicles entering Kuwait at an increased rate.

By 26 February 1991, the "Salem and Eugene Marines" of Company D advanced further to the northeast within Kuwait, to a position just west of Al Jaber Airfield. Here, as advance elements of 8th Engineer Support Battalion, they began construction of a third major logistic base to support future possible operations of the 1st and the 2nd

${ }^{178}$ Skipper, 8th ESB Command Chronology, p. 13. 

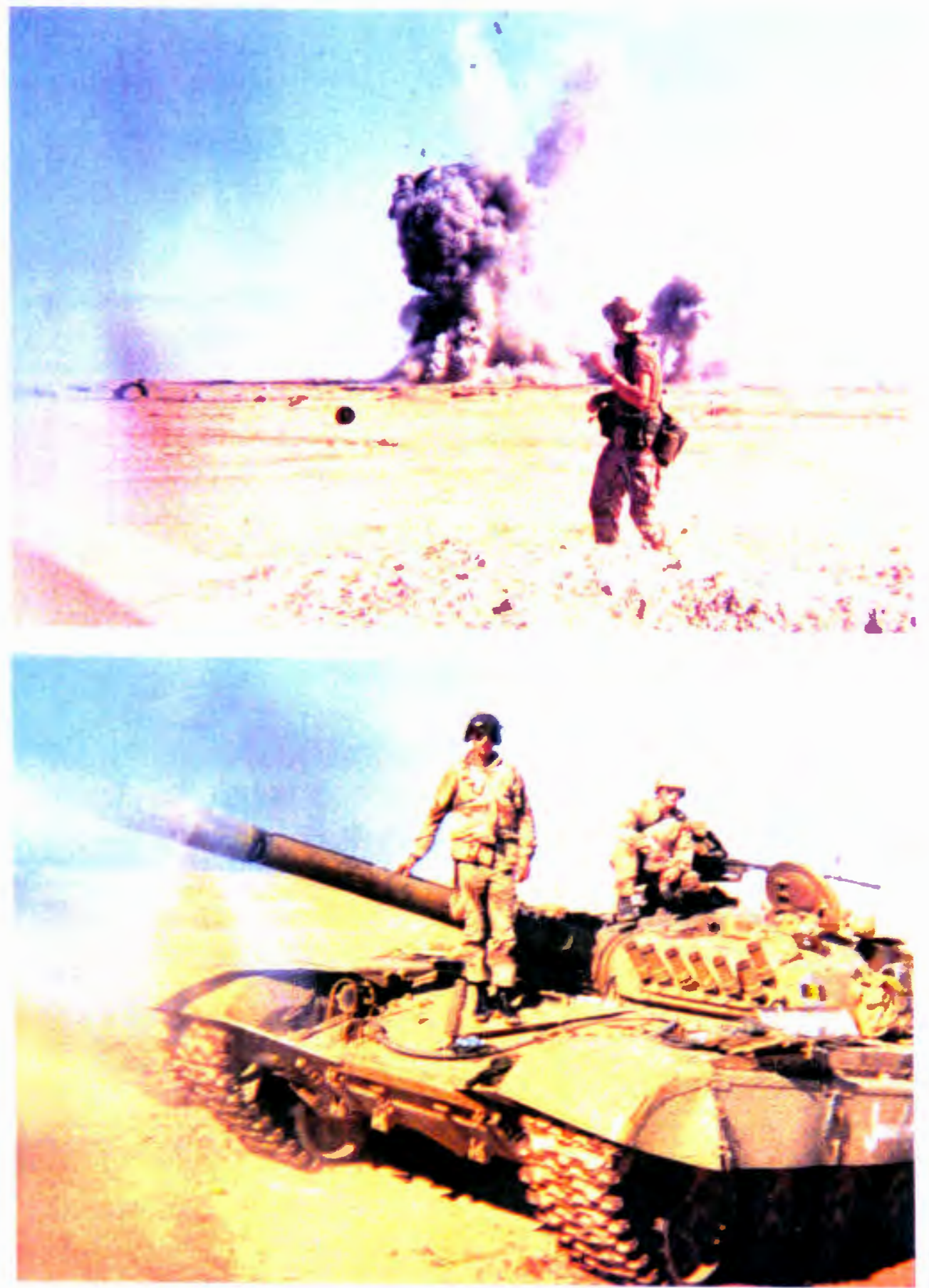

Figure 110 and 111: A Salem Marine involved in demolition project to destroy Iraqi ammunition bunkers in Kuwait. Second photo is of two Salem Marines atop captured Iraqi T-72 tank, February 1991.

Author's collection 
Marine Divisions. Mobility enhancement, obstacle reduction, road construction, survivability positions, and protective berms for ammunition storage points and fuel farms were again the order of the day.

At 0800 on 28 February 1991, the official "cease fire" for Operation Desert Storm went into effect. ${ }^{179}$ With the 1 st Marine Division occupying Kuwait International Airport and the 2nd Marine Division covering the only real avenue of approach to the west at Al Jahra, the full liberation of Kuwait was accomplished. Throughout this "one hundred hour war", the "Salem and Eugene Marines" of Company D, 8th Engineer Support Battalion, had helped to sustain the combat power of 2 nd Marine Division in its relentless drive north across Kuwait to Al Jahra and the Mutla Ridge.

Despite the rapid collapse of the Iraqi armed forces, there was as in all wars, a price to be paid. For America, it was 375 of her men and women, 66 of whom were United States Marines.

One Oregon Marine who experienced firsthand the death of a fellow Marine was Lance Corporal Jason E. Huston of Gresham, Oregon. A 1989 graduate of Hermiston High School, he joined the Marine Corps on 1 October 1989 as a reserve M-60 tank driver. Completing bootcamp at the Marine Recruit Depot San Diego, in December 1989, he then attended the Armor School at Fort Knox, Kentucky, from March through May 1990. Upon his return to Oregon, he moved briefly to Boise, Idaho, so as both to

${ }^{179}$ L. G. Caporale, "Marine Corps Historical Notes from the Gulf War, " Marine Corps Gazette, December 1991, p. 46. 
attend and also drill at Boise State College and the reserve unit at Boise: Company C, 4th Tank Battalion, 4th Marine Division. On 10 August 1990, following the Iraqi invasion of Kuwait, Huston was recalled to active duty for a two week period. At the Marine Reserve Center in Boise, he focused on preparing M-60 tanks for embarkation. Following this, the unit "stood down" (returned to reserve status) until 15 December 1991, when the entire unit was mobilized and sent to the Marine Corps Combat Center at 29 Palms, California. Here the Marine reserve tankers completed an intensive crash course program in which they transitioned from the old M-60 tank to the new M-1 Abrams tank, which had recently entered the Marine Corps. By the second week of February 1991, Lance Corporal Huston and his fellow Marine reserve tankers were on their way to the Persian Gulf, where they arrived on 15 February 1991. A three day period at Al Jubayl, Saudi Arabia was spent receiving their new M-1 tanks. So new was the tank that Huston and his crew received (they named it "Rude Dog") that its date of manufacture at the Chrysler plant in Detroit was 12 January 1991. As word was rampant of the impending start of the ground offensive against Iraq, the 14 tanks and crewmen of Huston's reserve tank company were ordered to link up with the 2nd Tank Battalion of 2 nd Marine Division. They rapidly headed north with their armor on lowbed trucks. At a forward staging area, Huston's "Rude Dog" was equipped with a new Israeli manufactured track width mine plow, so as to handle anticipated Iraqi anti-tank mines.

With the launching of the ground offensive on 24 February 1991, Huston's armor unit passed safely through the two Iraqi minefields, which had been breached by 2 nd 

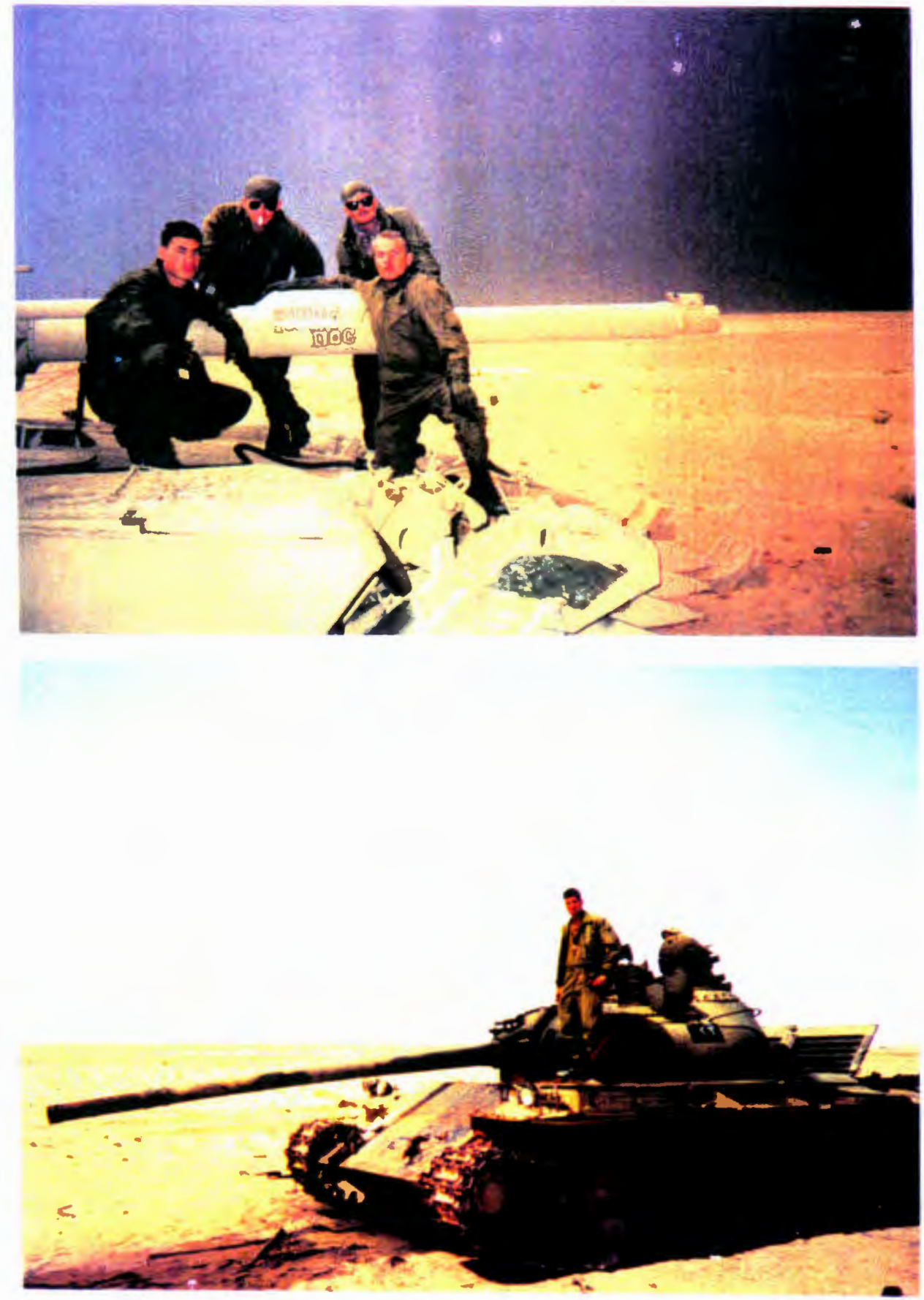

Figure 112 and 113: Jason E. Huston of Portland, serving as a Marine Reserve M-1 tank driver with 2nd Marine Division. This is his crew of "Rude Dog" of which the tank commander was later killed and the loader wounded. The second photo is of Huston atop an Iraqi T-55 which they destroyed, February 1991.

Author's collection 
Combat Engineer Battalion and were being widened by 8th Engineer Support Battalion (to which the "Salem and Eugene Marines" were attached). During this passage through the obstacle belts, Marines were subject to light Iraqi machine gun, mortar and artillery fire. 2nd Marine Division then proceeded to attack through the Umm Gudair and Al Manaquish oil fields. Together with the rest of 2 nd Tank Battalion, Company $\mathrm{C}$ swung north and spread out with the other tanks so as to cover 2nd Marine Division's front and flanks. On 27 February 1991, in a small Kuwaiti village near an area known as the "Ice Tray," Lance Corporal Huston's reserve company made contact with dug-in enemy armored vehicles. With poor visibility, a tank battle erupted in which the Marine reserve tankers of 2nd Platoon (4 M-1 tanks) destroyed a combination of two dozen Iraqi T-72, T-55, and PT-76 tanks and BMP armored personnel carriers. No Marine tanks were lost, but two Marine casualties were suffered when "Rude Dog" (amid the terrible light conditions of fog, smoke, and swirling sand) suddenly encountered a PT-76 at the extremely close range of 15 meters. Both the Marine tank commander and tank loader were not "buttoned up" in the turret so as to have better visibility. Lance Corporal Huston immediately slammed on the breaks as the tank commander and gunner fired the huge $120 \mathrm{~mm}$ high explosive anti-tank (HEAT) round into the doomed PT-76. Unfortunately, shrapnel from the close shell impact also killed Huston's tank commander and wounded the tank loader. "Rude Dog" was temporarily deadlined. Huston and his fellow surviving tank crew gunner received word of the ceasefire the next day. Following a month of patrol and garrison duty in Kuwait City, Huston and "Rude Dog" 


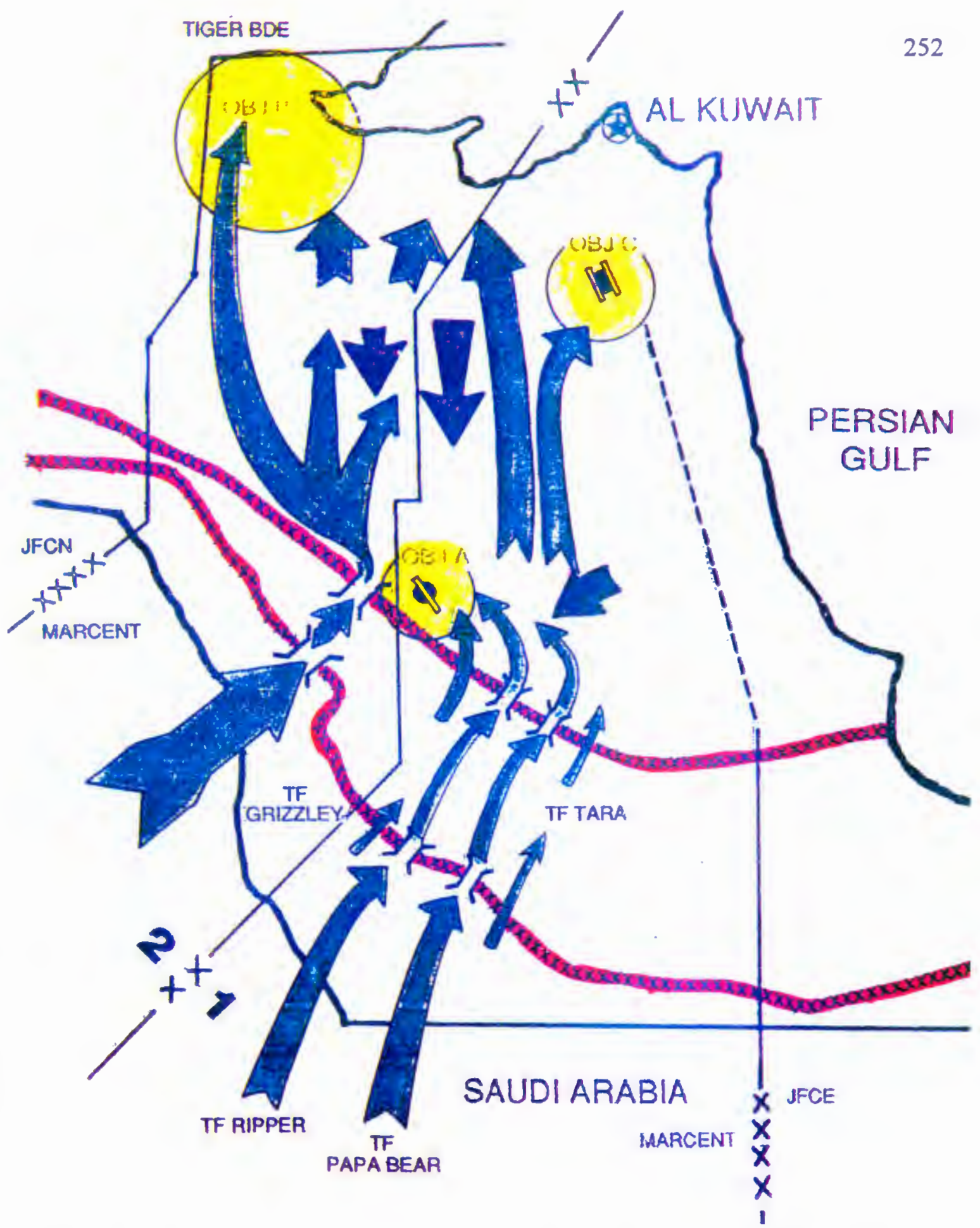

Figure 114: Detailed tactical map of Marine ground offensive at Operation Desert Storm, February 1991.

Courtesy of Mark E. Swanstrom Collection (2nd Marine Division Staff Engineer in Gulf War) 
returned in late March 1991 to Camp 3, outside of Al Jubayl, Saudi Arabia. After another month of armor embarkation evolutions, Lance Corporal Huston returned to the United States on 26 April 1991. Following two weeks of processing at Camp Lejeune, North Carolina, he bid farewell to 2nd Marine Division and returned to the Pacific Northwest on 15 May 1991. A year later, in May 1992, Corporal Huston transferred from the Marine reserve tank company in Boise, Idaho and returned to Oregon, where he joined 6th Engineer Support Battalion in Portland, the same month. Here he presently serves as a combat engineer. ${ }^{180} \quad$ Meanwhile, for their remaining seven weeks in Southwest Asia, the "Salem and Eugene Marines" contributed toward the massive American retrograde effort of cleaning and embarking equipment at Al Jubayl, Saudi Arabia. On 25 April 1991, they detached from 8th Engineer Support Battalion and bid farewell to the Persian Gulf. Transported back to Camp Pendleton, California, they completed their official out-processing.

On I May 1991 (the same day as the "Portland Marines"), the "Salem and Eugene Marines" returned home to Oregon amid an enthusiastic crowd at Portland International Airport. Following this, they were deactivated and rejoined their respective reserve units of Company A and 6th Bridge Company of 6th Engineer Support Battalion. ${ }^{181}$ For the third time in fifty years, Marine reserves from Oregon had returned home from war

${ }^{180}$ Personal Interview between Corporal J. E. Huston, and author, Portland, Oregon, 27 September 1994.

${ }^{181}$ Personal Interview between Kuhn and author, p. 2. 
following faithful service to their nation. On 8 June 1991, just over half of 6th Engineer Support Battalion had not been activated for the Gulf War. June 1991 these Marines deployed to the Marine Air Ground Combat Center, 29 Palms, California, where they did extensive combat engineer work in constructing the Mechanized Assault Obstacle Course at Emerson Lake. This Operation Desert Support 91, became the largest combined arms mobility-countermobility exercise course ever constructed in the Marine Corps and it incorporates all the combat engineer lessons during the Gulf War. It was featured in the January 1993 issue of the Marine Corps Gazette.

President Bush presented the battle colors of the United States Marine Corps with its 49th streamer covering the war in Southwest Asia. ${ }^{182}$ At the Marine Corps Reserve Center, Swan Island, Portland, on the beautiful Sunday morning of 7 August 1994 (also the 52nd Anniversary of the Marine landing on Guadalcanal), another important ceremony took place. Backed by a formation of "Portland Marine" Gulf War veterans, Lieutenant Colonel Alfredo Juan Arguedas USMCR, the battalion commander of 6th Engineer Support Battalion, placed the Southwest Asian battle streamer on the battalion's colors. Taking place at the annual Marine Family Day, this ceremony was followed by two less formal, but equally meaningful events: the dedication in front of the Reserve Center of a vintage $105 \mathrm{~mm}$ howitzer static display to honor the Korean War "Chosin Few", and the backlot display of a World War II TD-18 armored bulldozer (in the final stages of restoration) to honor the long line of Oregon Marine engineers. It was

${ }^{182}$ Caporale, Gazette, p. 46. 

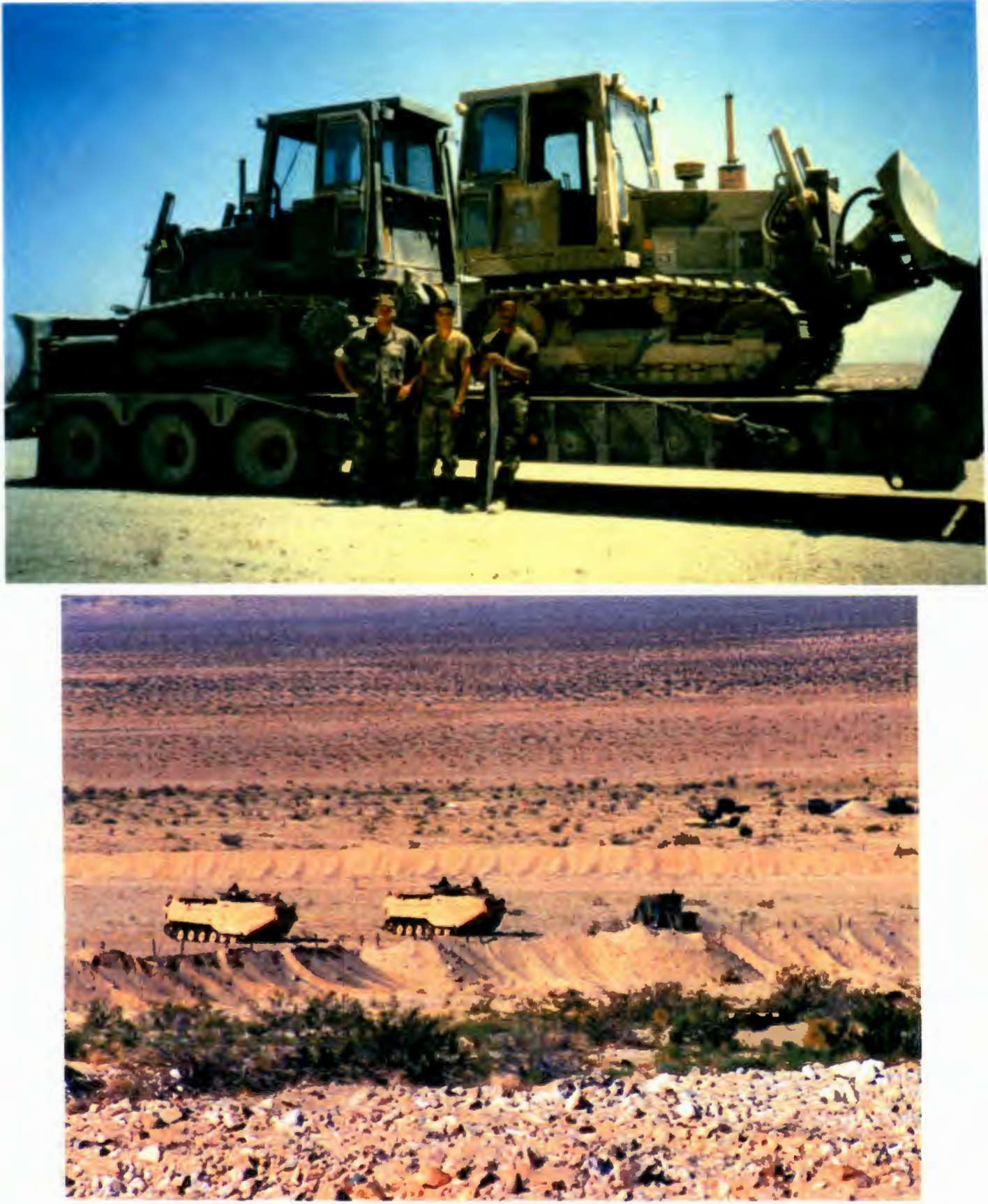

Figure 115 and 116: Oregon Marines of 6th Engineer Support Battalion at Operation Desert Sapper, Marine Air Ground Combat Center, 29 Palms, California, June 1991. This extensive combat engineer training was based on Gulf War lessons and construction of Marine Corps' largest mechanized assault obstacle course.

Author's collection 
only appropriate that amid the large crowd of family and well-wishers, were dozens of Oregon Marine reserve veterans of World War II, Korea, and Vietnam.

The Oregon Marines of 6th Engineer Support Battalion have continued to demonstrate their professionalism since the Gulf War. From "fully ready" results on its extensive 1992 Mobilization and Operational Readiness Deployment Test, to its 1994 Schmidt Award selection as the outstanding battalion in 4th Force Service Support Group, "Oregon's Marines" of 6th Engineer Support Battalion have continued to set the standard for the Marine Reserve community. Of equal importance are the strong bonds that the command had forged with both the civilian community and its extended Marine family. One prime example of this was the battalion's consecutive 1992 and 1993 summers (Operation Nehemiah and Rorkes Drift II) of major earth excavation work for the Oregon Parks and Recreation Department. Following a tactical amphibious landing using Landing Craft Air Cushioned (LCAC) vehicles CH- 53 helicopters, the battalion launched into a realistic scenario involving all aspects of its engineer mission and basic Marine warrior skills. This also focused on the restoration of Civil War Historic Fort Stevens, at the mouth of the Columbia River and trail improvement using demolitions on Saddle Mountain. Another example was the "Salem Marines" and their joint project with the city of Stayton in restoring and reconstructing the Jordan Covered Bridge. This was the first such covered bridge salvage operation in Oregon history. A final example would be the "Eugene Marines" ongoing support of the Oregon Fish and Wildlife Department in improving fish habitats by blasting spawning pools and utilizing demolitions to drop 


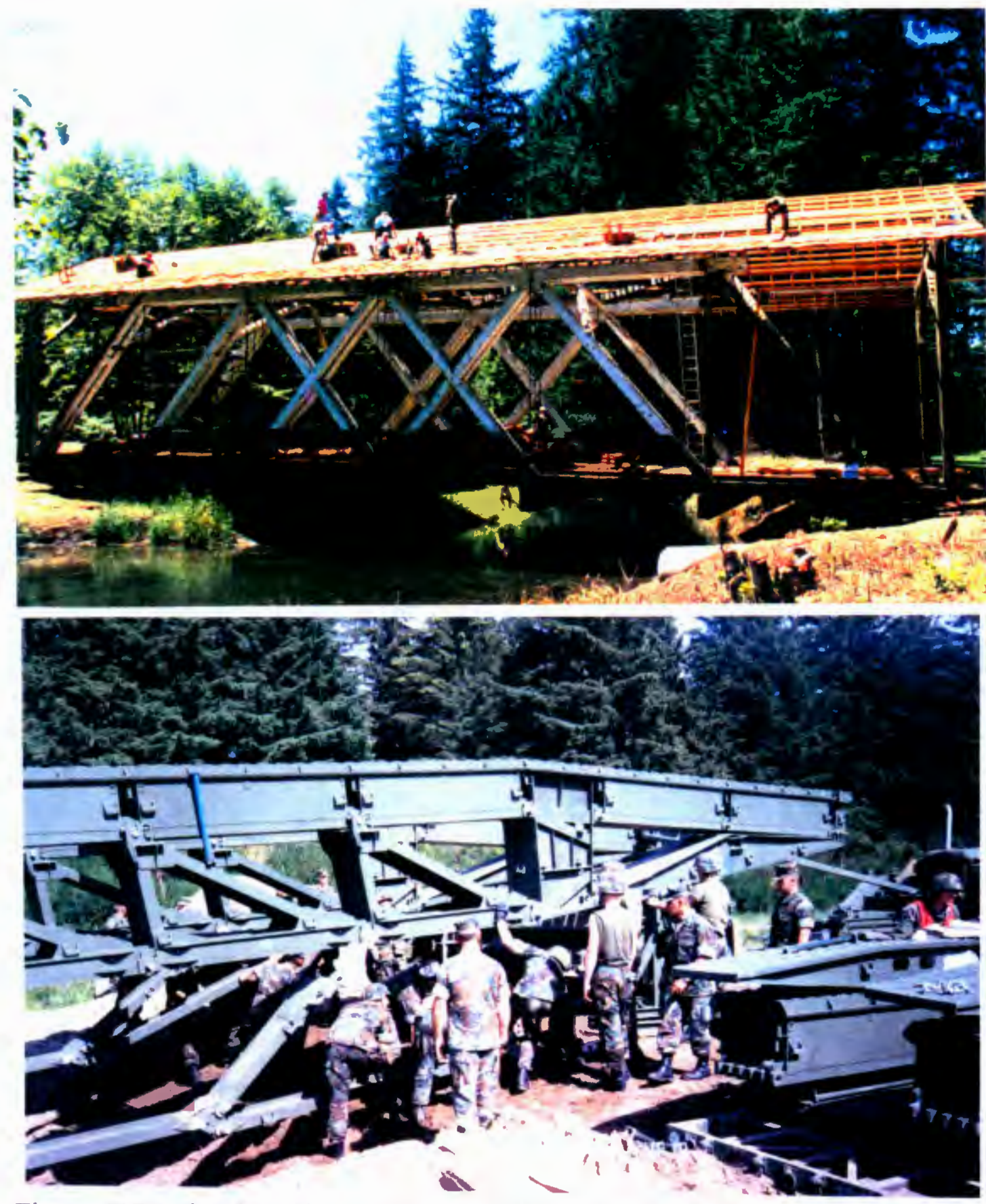

Figure 117 and 118: Salem and Eugene Marines conduct bridge training in Oregon First photo is of the restoration of the Jordan Covered Bridge in Stayton. The second photo is Medium Girder Bridge operations at Camp Rilea during annual training in June 1993.

Author's collection 

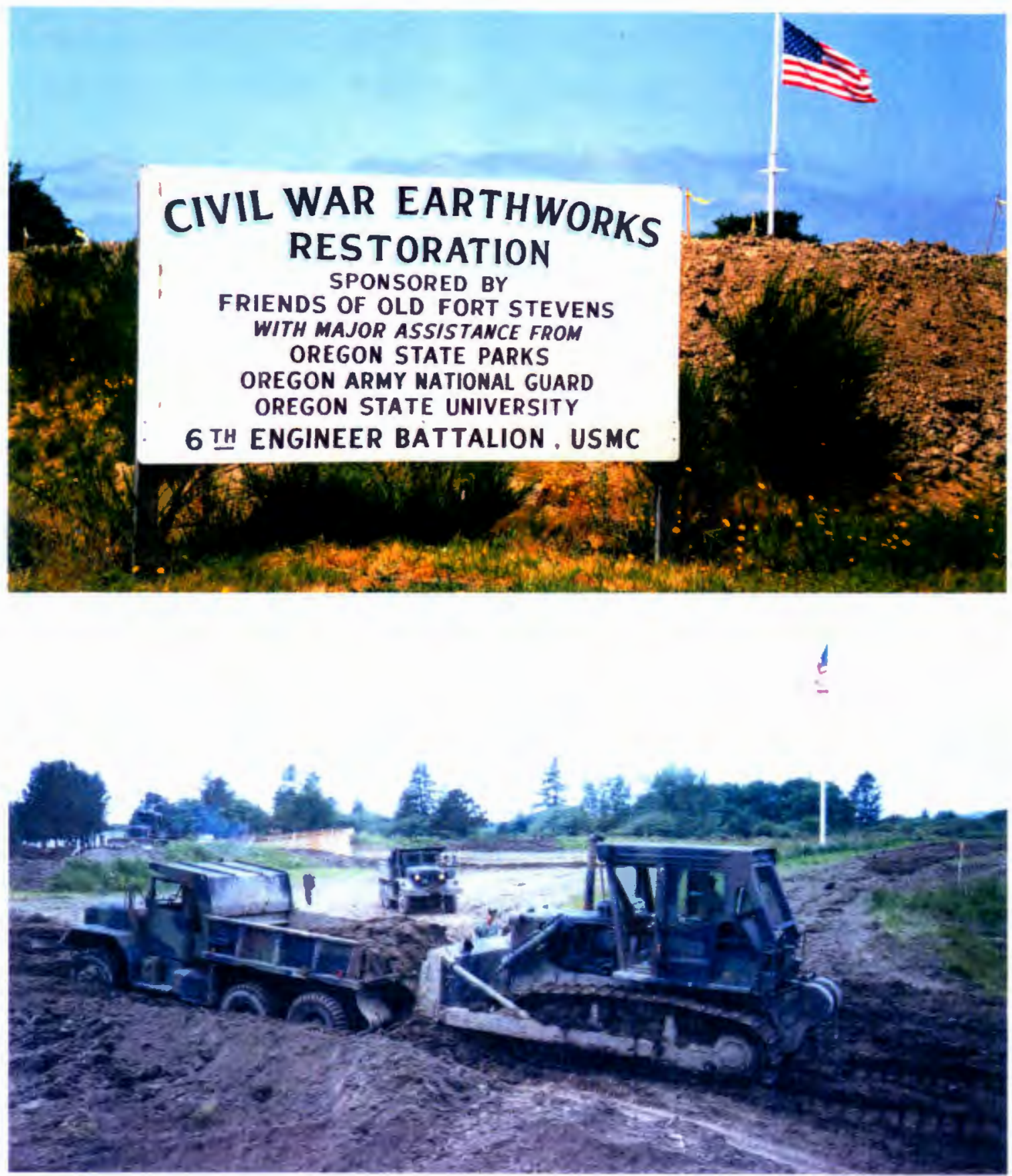

Figure 119 and 120: Oregon Marines of 6th Engineer Battalion conduct community service project on behalf of Oregon Parks and Recreation Department, June 1992 and June 1993. Demolitions work on Saddle Mountain trail improvement project was also conducted.

Author's collection 

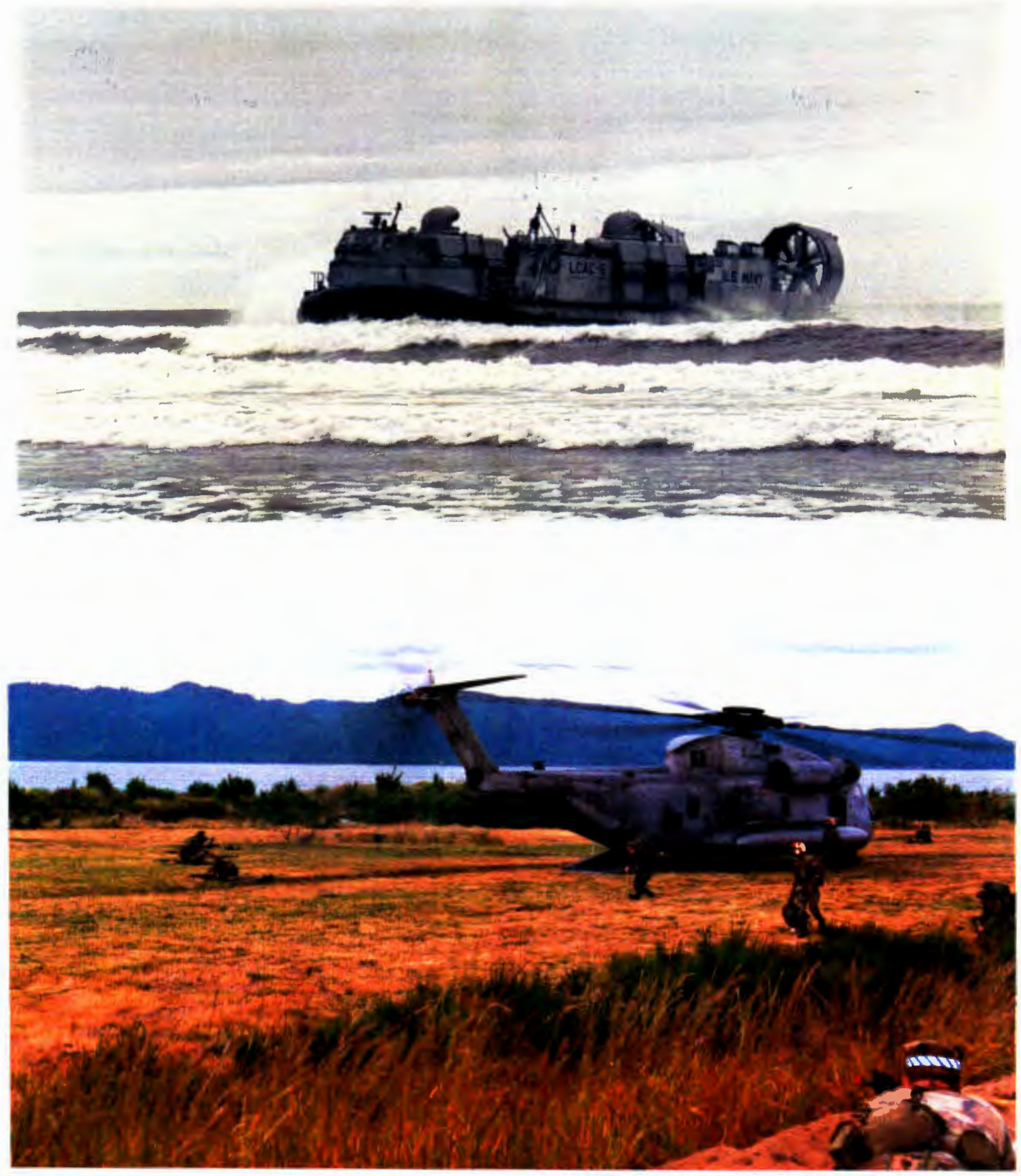

Figure 121 and 122: Oregon Marines of 6th Engineer Support Battalion conduct amphibious operations off of Fort Stevens, at the mouth of the Columbia River. Top photo is of Landing Craft Air Cushion (LCAC) full of Marines and their equipment landing from offshore shipping. Bottom photo is Marines landing from $\mathrm{CH}-53$ helicopters at Fort Stevens, June 1992 and June 1993.

Author's collection 
trees into famous Salmon and Steelhead rivers such as the Nestucca. Other vintage projects such as the Toys For Tots program during Christmas, the Drug Awareness Resistance Education (DARE) program presentations in schools, and "Operation Standown" for homeless veterans and their families, are other examples of behind the scenes Marine Corps civic activities.

There is a saying in the Corps that: "Once a Marine, always a Marine." To further maintain strong and useful ties with the retired and veteran Marine communities, the Marine Corps Coordinating Council of Greater Oregon was established in 1993. This organization strives to ensure a sense of teamwork between some two dozen Marine organizations, ranging from the large and vibrant 1st Marine Division and Chosin Few Oregon chapters, to the various city Marine Corps Leagues, to the smaller and diminishing World War I, China Marine, and Wake Island organizations. These Oregon Marine veterans have made significant contributions to the rich history of America and their participation in the annual Marine Corps Birthday Ball, Marine Family Day, the Marine Family Support Group, and other patriotic civic activities are warmly appreciated throughout Oregon. On 1 November 1994, the 50th Anniversary of 6th Engineer Battalion, it was only appropriate that Harry H.W. Niehoff (the oldest Oregon Marine Reserve veteran and a combat engineer) dedicated a memorial in memory of the long line of Oregon Marine Reserve engineers. This memorial consisted of a restored W.W.II International Harvester TD-18 Armored Bulldozer in front of the Portland Marine Reserve Center. Standing in the rain lending support to Niehoff, were some thirty 
Marine well wishers representing a vast wealth of Oregon's Marine heritage. This was indeed a solemn and special occasion.

Marines in and from Oregon have been a faithful part of the overall proud legacy of the United States Marine Corps. They have participated in, preserved and passed down the traditions of the Corps to succeeding Oregon generations. Their contributions are many. Marines such as Quartermaster Sergeant Marion A. Stearns of the USS Vincennes and his 1841 landing in Oregon with the Wilkes Expedition. First Lieutenant Archibald H. Gillespie delivered President Polk's secret message to John C. Fremont in 1846 at Klamath Lake. Private Charles 0. Schroeder of Oak Grove, served aboard the USS Olvmpia at the 1898 Battle of Manila Bay. First Lieutenant Albert G. Skelton of Corvallis, earned the Silver Star and French Croix de Guerre in 1918 at Belleau Wood and later formed the first Oregon Marine Reserve unit aboard the USS Oregon. First Lieutenant Marion E. Carl of Hubbard, become the first Marine Corps ace in 1942 over Guadalcanal. Corporal Harry H. W. Niehoff of Portland, survived Pearl Harbor and earned the Silver Star in 1943 on Tarawa and the Bronze Star in 1944 on Saipan. Private First Class Arthur L. Jackson won the Medal of Honor in 1944 on Peleliu. Sergeant Hubert J. Faltyn of Salem, received the Navy Cross and a battlefield commission in 1945 for his service on Iwo Jima. Captain Robert P. Wray of Corvallis, was wounded earning two Silver Stars and a Bronze Star in 1950 and 1951 in Korea. And Private First Class Gary W. Martini of Portland, earned posthumously in 1967, the Medal of Honor in Vietnam. All are but a small part of the Oregon Marine heritage. 
Though small in population base, and relatively late in entering the union, Oregon's contributions to the history of the United States Marine Corps has been significant.

Today, Oregon Marines of the 6th Engineer Support Battalion may well wish to reflect on the Biblical story of Nehemiah, which tells us that when the nation of Israel returned to their homeland from captivity, they determined to rebuild the walls of Jerusalem. In spite of the threats of the enemy, the wall was built and the peace was preserved. But it was written: "Of them that built on the wall $\ldots$ with one of his hands he did the work, and with the other he held the sword." ${ }^{183}$

Past, present, and future Oregon Marines, whether infantry, artillery, or engineers, are also reminded of their dual role by the engraved silhouette on the Organized Marine Corps Reserve Medal. It depicts both a citizen and a Marine walking side by side. As dedicated Marines, they hold the sword and are determined to safeguard America's freedom. But as responsible Citizens, they also hold the trowel, and are equally determined to build and preserve their nation, their Corps, their state and their unit so that those who come after them will find the same heritage and bountiful resources that Americans now cherish.

In an age where leadership by example, duty, honor, and self-sacrifice appear to be in short supply, perhaps this story of Oregon's Marines can encourage and motivate

\footnotetext{
${ }^{183}$ Nehemiah, Old Testament book of The Bible, Chapter 4, Verse 18, Revised Standard Version, Harper Study Edition, p. 687.
} 
others to accept the challenge that any truly successful life must be based upon service to others. This is not news to Marines. It is a time honored tradition preserved in the Corps' motto "Semper Fidelis" (Always Faithful), and it is responsible for the United States Marine Corps being one of the closest knit and most reputable fighting organizations in world history. For those unfamiliar with the meaning of the cherished Marine term "Esprit de Corps," its meaning can best be summarized in the words used by Shakespeare to describe brotherhood:

"But we in it shall be remembered, we few, we happy few, we band of brothers. For he today that sheds his blood with me Shall be my brother."

\section{Henry the Fifth Act IV, Scene III}

This might well be the "Marine Hymn" sung by Shakespeare. 


\section{BIBLIOGRAPHY}

Research Note: The articles and books referenced below formed the framework and provided essential detail for "Oregon's Marines." However, the majority of the work went into locating, contacting, interviewing, and corresponding with over a hundred Marine veterans. The resulting surveys, files and tapes, all based upon firsthand data collected by the author, have been donate $t$ to the United States Marine Corps by way of the Marine Corps Historical Center, Building 58, Washington Navy Yard, 901 M Street, S.E., Washington, D.C. 20374- 5040.

I. Primary Sources

A. Interviews by Author

1. Adams, William B., Portland, OR, 12 Dec 1993

2. Arguedas, Alfredo Juan, McMinnville, OR, 16 Apr 1994

3. Aubin, Kenneth Alvin, Boring, OR, 3 Oct 1993

4. Ball, Edwin Bruce, Portland, OR, 6 Dec 1993

5. Barker, Jeffrey Heim, Aloha, OR, 22 Feb 1994

6. Barnes, Michael Vincent, Portland, OR, 2 and 8 Sep 1994

7. Bergman, Leslie W., Canby, OR, 14 Oct 1993

8. Bigbee, John H., Clackamas, OR, 6 Feb 1994

9. Bodenweiser, Alec Jeffrey, Salem, OR, 2 Mar 1994

10. Bostick, William Frank, Portland, OR, 28 Feb and 4 Apr 1994

11. Boyd, Daniel Z., Ashland, OR, 13 Oct 1993

12. Bradbury, David M., Grants Pass, OR, 16 Apr 1994

13. Brandon, P.E. "Gunny", McMinnville, OR, 2 Nov 1993 and 17 Apr 1994.

14. Buchea, Francis J., Umpqua, OR, 17 Jan 1994 
15. Buckley, John Edward, Grants Pass, OR, 16 Apr 1994

16. Burnett, W. Elliott Jr., Dallas, TX, 4 Dec 1993

17. Callison, David Edward, Portland, OR, 17 Feb 1994

18. Campbell, Donald H., Waldport, OR, 20 Dec 1993

19. Campbell, Lundy John, Portland, OR, 1 and 17 Aug 1994

20. Carl, Marion Eugene, Roseburg, OR, 12 May 1994

21. Coles, Clarence W., Cucamonga, CA, 11 Sep 1993

22. Dackins, Don N., Portland, OR, 21 Mar 1994

23. Dowdakin, David W., Portland, OR, 6 Jul and 3 Oct 1994

24. Drake, Elmer Sidney Jr., Portland, OR, 28 Feb and 4 Apr 1994

25. Enores, Raymond J., Ashland, OR, 17 Oct 1993

26. Evans, William Roy Jr., Central Point, OR, 2 Apr 1994

27. Faltyn, Hubert Joseph, Salem, OR, 29 Nov and 7 Dec 1993, 15 Apr 1994

28. Geissler, Eric, Corvallis, OR, 14 Nov 1993

29. Gerber, Bernard Wyman, Portland, OR, 22 Mar and 2 Jun 1994

30. Gerow. Eric B., Portland, OR, 26 Sep 1991

31. Gladbach, James, Salem, OR, 12 and 17 Sep 1991

32. Gould, Eldon Earl, Portland, OR, 17 Sep and 2 Dec 1993

33. Gray, Jeannine A. "Bunny", Portland, OR, 7 Mar 1994

34. Green, Thomas G., Portland, OR, 9 and 11 Dec 1993

35. Groulx, Richard William, Portland, OR, 18 Feb 1994 
36. Harshberger, John Daniel, Leaburg, OR, 22 Mar 1994

37. Heinz, Jerome M., Tillamook, OR, 23 Nov 1993

38. Henderson, Clyde T, Portland, OR, 7 Mar 1994

39. Henderson, Robert Dale, Vancouver, WA, 9 Dec 1993

40. Hering, John Clinton, Milwaukie, OR, 15 Nov 1993

41. Hewitt, Harold K., Beaverton, OR, 17 Dec 1993

42. Hobbs, W.R., Portland, OR, 9 Sep 1991.

43. Hunt, Harry A. Jr., La Grande, OR, 16 Oct 1993

44. Huntsinger, Lester Roy, Salem, OR, 27 Nov 1993

45. Huskey, Wayne Warren, Stayton, OR, 3 Apr 1994

46. Huston, Jason Edward, Portland, OR, 29 Jul 1994

47. Huxel, Emil E., The Dalles, 7 Aug 1994

48. Jackson, Arthur J., Boise, ID, 14 Jan and 11 Apr 1994

49. Johnson, Thelma, Klamath Falls, OR, 4 Apr 1994

50. Key, Cecil, Forest Grove, OR, 19 Nov and 6 Dec 1993, 5 Nov 1994

51. Kuhn, Randy, Portland, OR, 2 Sep 1991.

52. Kuzirian, Jack, Aloha, OR, 23 Feb 1994

53. Kyser, Frank Wilford, Milwaukie, OR, 7 Oct 1994

54. Lamothe, Lloyd G.A., Troutdale, OR, 22 May 1994

55. Larsen, Carl Viggo "Swede", Lebanon, OR, 13 Jan 1994

56. Ludwig, Martin Albert, Roseburg, OR, 4 Oct 1993 
57. Martinez, Ralph James, Portland, OR, 18 Mar 1994

58. Martinez, Robert Nelse, Sylmar, CA, 2 May 1994

59. Martinez, Raymond Leroy, Beaverton, OR, 11 May 1994

60. Martinez, Joseph Anthony, Northridge, CA, 8 May 1994

61. Martinez, Lawrence Dennis, Madras, OR, 12 May 1994

62. Martinez, Frank William, Beaverton, OR, 4 May 1994

63. May, Charles W., Astoria, OR, 16 Dec 1993

64. McKee, Carl James Jr., Pleasant Hill, OR, 28 Oct 1993

65. McKellips, Arthur Eugene, Hillsboro, OR, 15 Oct 1994

66. McLeod, Carl J., Salem, OR, 1 Dec 1993

67. Mohn, David Henry Jr., Seaside, OR, 20 Feb 1994

68. Moniot, Joseph E., Olympia, WA, 7 Aug 1994

69. Montgomery, Lucille, Gresham, OR, 24 Jan 1994

70. Morgan, Gordon William, Portland, OR, 29 Nov and 7 Dec 1993

71. Niehoff, Harry Herman William, Portland, OR, 21 Mar 1994

72. O'Connor, William E., Stayton, OR, 6 Jan and 16 Apr 1994

73. Olsen, Louis Clinton, Milwaukie, OR, 14 Aug 1994

74. Olson, Otto N., La Center, WA, 27 Aug and 2 Oct 1994

75. Ostrin, Steve L., Salem, OR, 21 Nov 1993

76. Parker, Frederick David, Aloha, OR, 11 Oct 1993

77. Pileggi, Vito Paxton, Stayton, OR, 12 Mar 1994 
78. Ping, William A. "Bill", Desert Hot Springs, CA, 12 Dec 1993

79. Price, Irma, Portland, OR, 15 Mar 1994

80. Price, Leonard V., Bandon, OR, 23 Nov 1993

81. Putnam, R.E., Portland, OR, 6 Oct 1991

82. Rasch, G. Clark, Pistol River, OR, 10 Dec 1993

83. Reva, Barbara A., Medford, OR, 17 Nov 1993

84. Rose, Frank, Murphy, OR, 27 Nov 1993

85. Ruhberg, George Thomas, Portland, OR, 18 Apr 1994

86. Saraceno, Victor, J., Portland, OR, 19 Nov 1993

87. Sellers, Harrell G. "Hal", Portland, OR, 7 Aug and 5 Oct 1994

88. Schneiter, Melvin R., Fossil, OR, 4 Nov 1993

89. Sherman, John Wilson, Lincoln City, OR, 12 Dec 1993

90. Simpson, David W., Portland, OR, 14 Jan 1994

91. Sloan, Clyde, Newport, OR, 2 Nov 1993

92. Specht, Lyle, E., Tillamook, OR, 15 Dec 1993

93. Starr, T.E., Eugene, OR, 12 and 17 Sep 1991

94. Stevens, John R., San Francisco, CA, 22 Apr 1994

95. Tandecki, Bernard G., Willamina, OR, 26 Oct 1993

96. Thomas, Claude M., Portland, OR, 20 Nov 1993

97. Tremaine, Hugh Stewart, Portland, OR, 18 Mar 1994

98. Vannatta, Raphael T., Talent, OR, 22 Nov 1993 
99. Wallace, Lee A., Dallas, OR, 24 Apr 1994

100. Warner, Gordon D., Portland, OR, 14 Jan 1994

101. Warren, Charles Earl, Salem, OR, 18 Oct 1993

102. Waibel, T.R., Portland, OR, 1 Oct 1991

103. Wilson, Arthur, Portland, OR, 5 Jan 1994

104. Wray, Robert P., Corvallis, OR, 12 Feb 1994

105. Zinni, Anthony C., Iwo Jima, Japan, Jan-Feb 1989 (3rd Marine Division/9th Marine Regiment Battle Studies Program/deployment)

II. Secondary Sources

A. Articles and Books

1. Anderson, Ross and Keith Benson, "They Put the Northwest on the Map" in The Seattle Times/Seattle Post Intelligencer. Seattle, September 20, 1987.

2. Asprey, Robert B., At Belleau Wood. New York: G.P. Putnam's Sons, 1965.

3. Barkan, Frances B., The Wilkes Expedition. Olympia, Washington, 1987.

4. Bartlett, Merrill L., Assault From the Sea, Essays on the History of Amphibious Warfare. Annapolis, Maryland: Naval Institute Press, 1983.

5. Bartley, Whitman S., Iwo Jima: Amphibious Epic. Headquarters U.S. Marine Corps: Historical Branch, G-3 Division, 1954.

6. Boatner III, Mark Mayo, Encyclopedia of the American Revolution. New York: David McKay Company, Inc., 1974.

7. Camp Adair, Sentry, Volume III, \#2, 5 May 1944.

8. Camp Adair, Sentry Volume III, \#8, 9 June 1944. 
9. Caporale, L.G., "Marine Corps Historical Notes from the Gulf War," Marine Corps Gazette. December 1991.

10. Carl, Marion E., Pushing the Envelope. Annapolis: United States Naval Institute Press, 1994.

11. Cass, Bevan G., History of the Sixth Marine Division. Nashville: The Battery Press, 1987.

12. Columbia Maritime Museum, Quarterdeck Review, Vol. 12, No. 4. Astoria, Oregon, Fall 1985.

13. Columbia Maritime Museum, The Quarterdeck. Vol. 19, \#2, Winter 1993.

14. Cooper, Norman V., A Fighting General The Biography of Gen Holland M. "Howlin' Mad" Smith. Quantico: The Marine Corps Association, 1987.

15. Devereux, James P.S., The Story of Wake Island. New York, 1947.

16. Dodds, Gordon B., The American Northwest. Arlington Heights, Illinois, 1986.

17. Donovan, Jr., James A., The United States Marine Corps. New York: Frederick A. Praeger, Publishers, 1967.

18. Dupuy, R. Ernest and Trevor N. Dupuy, The Harper Encyclopedia of Military History. New York: Harper Collins Publishers, 1993.

19. Eggenberger, David, An Encyclopedia of Battles. New York: Dover Publications, Inc., 1967.

20. Flannigan, James C., The Oregonian. Portland, Oregon, 9 Feb 1986.

21. Freeman, Douglas Southall, George Washington, A Biography Volume One Young Washington. New York: Charles Scribner's Sons, 1949.

22. Garrett III, H. Lawrence, "A Tribute to the Corps," Marine Corps Gazette, January 1992, p. 36-37. 
23. Gilkerson, William, The Ships of John Paul Jones. Annapolis: Naval Institute Press, 1987.

24. Griffith II, Samuel B., The Battle for Guadalcanal. Mt. Vernon, Maine: The Nautical and Aviation Publishing Company of America, 1963.

25. Hammel, Eric, Chosin, Heroic Ordeal of the Korean War. Novato, CA: Presidio Press, 1981.

26. Hanft, Marshall, Fort Stevens, Oregon's Defender at the River of the West. Hammond \& Portland, Oregon, 1980.

27. Harmon, Rick, Oregon Historical Quarterly. Portland: Oregon Historical Society, Volume 92, No. 2, Summer 1991.

28. Heinl, Jr. Robert Debs, Dictionary of Military and Naval Quotations. Annapolis, 1966.

29. Heinl, Jr. Robert Debs, Soldiers of the Sea, The U.S. Marine Corps. 1775-1962. Annapolis: Naval Institute Press, 1962.

30. John, D.L., 7th Engineer Support Battalion Unit Status/Engineer Situation Report. Employment of 6th Engineer Support Battalion Personnel. Al Kibrit, Saudi Arabia, 1 January 1991.

31. Key, Cecil, Military Record, Discharge Papers. Forest Grove, Oregon, 19 November and 6 December 1993.

32. Kohn, George C., Dictionary of Wars. New York: Anchor Press, Doubleday, 1986.

33. Krulak, C.C., "Combat Service Support in the Desert," Marine Corps Gazette. October 1991.

34. Lukeman, A., Guidebook for Marines. Quantico, Virginia, 1990.

35. Marine Corps Association, Leatherneck, Magazine of the Marines. Quantico, Virginia, October 1955.

36. Marshall, Douglas W., Campaigns of the American Revolution. Ann Arbor: The University of Michigan Press, 1976. 
37. Matthews, Richard P., "Taking Care of Their Own: The Marine Barracks at Klamath Falls, Oregon", Oregon Historical Quarterly, Winter 1992-93.

38. Mayo, Robert S., With the Marines on Okinawa. Lancaster, Pennsylvania 1946/1976.

39. McHenry, Robert, Webster's American Military Biographies. New York: Dover Publications, Inc., 1978.

40. McMillan, George, The Old Breed A History of the First Marine Division in World War II. Washington DC: Zenger Publishing Co., Inc., 1949.

41. Metcalf, Clyde H., A History of the United States Marine Corps. New York: G.P. Putnam's Sons, 1939.

42. Mewha, John, "The Oregon Guard's 'Navy'." Columbia River Maritime Museum: Quarterdeck Review. Vol. 12, No. 4, Astoria, Oregon, Fall, 1985.

43. Miller, William M., A Chronology of the United States Marine Corps. 1775-1934. Washington D.C.: Historical Branch, Headquarters, USMC, 1965 .

44. Millett, Allan R., Semper Fidelis: The History of the United States Marine Corps. New York: Macmillan Publishing Co., Inc., 1980.

45. Morison, Samuel Eliot, John Paul Jones: A Sailor's Biography. Boston: Little, Brown and Company, 1959.

46. Moskin, J. Robert, The U.S. Marine Corps Story. New York: McGraw-Hill Book Company, 1977.

47. Moulton, J. L., The Royal Marines. Eastney, Southsea, Hampshire, Great Britain: Leo Cooper Ltd., 1972.

48. Munyan, May G., Du Pont $=$ The Story of a Company Town. Puyallup: The Valley Press, Inc., 1972.

49. Murray, Regina Waldron, "Retreat, Hell ..." United States Naval Institute Proceedings. Annapolis, Maryland, January 1985. 
50. Naval Air Station Tillamook, NAST, Newsletter, Volume III, \#7, Tillamook, Oregon, 1 February 1946.

51. National Archives, Official Military Record of A.G. Skelton. Washington D.C.

52. Nehemiah, Old Testament book of the Bible. Zondervan Publishing House, Harpers Study Edition, Grand Rapids, Michigan, 1962.

53. Nichols, Jr., Charles S., Okinawa: Victory in the Pacific. Headquarters, U.S. Marine Corps: Historical Branch, G-3 Division, 1955.

54. Oregonian. Portland, Oregon, May 4, 1941.

55. Oregonian, Obituary. Portland, Oregon, 14 July 1962

56. Oregon Journal. Portland, Oregon, December 6, 1953.

57. Ota, Masahida, The Battle of Okinawa. The Typhoon of Steel and Bombs. Tokyo: Kume Publishing Company, 1984.

58. Parker, William D., A Concise History of the United States Marine Corps 1775-1969. Washington, D.C.: Historical Division, Headquarters, USMC, 1970.

59. Perkins, Lucille, Old Salts. Tongue Point Reunion Publication, Warren, Oregon, 1983.

60. Portland Police Department Employment Questionnaire Portland, Oregon, September 15, 1930.

61. Preston, Anthony, Navies of the American Revolution. Englewood Cliffs, New Jersey: Prentice-Hall Inc., 1975.

62. Public Affairs Unit 4-1, The Marine Corps Reserve, $\underline{\text { History. }}$ Washington D.C., 1966.

63. Read, Benjamin S., "Our Guns Never Got Cold," The Saturday Evening Post April 7, 1951.

64. Ross, Bill D., Iwo Jima Legacy of Valor. New York: The Vanguard Press, 1985. 
65. Ryan, Cornelius, $\underline{A}$ Bridge Too Far. Son Bridge film scene with Michael Caine. New York, 1974

66. Sackett, P.F., After Action Report. 6th Engineer Battalion, Battle for Okinawa, Japan, 21 June 1945.

67. Schaffer, Ronald, Small Wars Manual, United States Marine Corps, 1940. Manhattan, Kansas: Sunflower University Press, 1940 reprint.

68. Schwarzkopf, H.N., Desert Storm Press Briefing. Cable News Network, Riyadh, Saudi Arabia, 27 February 1991.

69. Selby, John, United States Marine Corps. New York: Hippocrene Books, Inc., 1972.

70. Shane, Harley S. and Paul D. Stevens, The Congressional Medal of Honor. The Names. The Deeds. Chico, California: Sharp and Dunnigan Publications, 1988.

71. Sherrod, Robert, History of Marine Corps Aviation in World War II. San Rafael, 1952.

72. Simmons, Edwin H., The United States Marines. London: Leo Cooper Ltd., 1974.

73. Silverstone, Paul H., Warships of the Civil War Navies. Annapolis, Maryland, 1989.

74. Skipper, C.O., 8th Engineer Support Battalion Command Chronology, Enclosure (1), Section B, Deployment, (4) Reserve Support. Al Khanjar, Saudi Arabia, 12 March 1991.

75. Smith, Charles R., Marines in the Revolution: A History of the Continental Marines in the American Revolution 1775- 1783. Washington, D.C.: History and Museums Division, Headquarters, U.S. Marine Corps, 1975.

76. Smith, Holland M., Coral and Brass. Zenger Publishing Company, Washington, D.C., 1948.

77. Snyder, Eugene E., Portland Names and Neighborhoods: Their Historic Origins. Portland, Oregon, 1979. 
78. Speck, Gordon, Northwest Explorations. Portland, OR, 1954.

79. Stanton, William, The Great United States Exploring Expedition of 1838-1842. Berkeley, CA, 1975

80. Steinberg, Rafael, Island Fighting. Alexandria: Time-Life Books, 1978.

81. Sternlicht, Sanford, McKinley's Bulldog: The Battleship Oregon. Chicago, Illinois, 1977.

82. Telfer, G.L. and V.K. Fleming Jr., U.S. Marines in Vietnam, Fighting the North Vietnamese. Washington D.C., 1967.

83 Thomas, Gerald C., The Marine Officer's Guide. Annapolis, Maryland: Naval Institute Press, 1975.

84. Thomason, John W., Fix Bayonets! Quantico: The Marine Corps Association, 1925

85. United States Marine Corps, History of the 12th Marine Corps District. San Francisco, California, 19 April 1957.

86. Vaughan, Thomas, "River of the West" in American History Illustrated. Volume XXVII, \#2, May/Jun 1992.

87. Veterans of Foreign Wars (VFW), 50th Anniversary of WWII Magazine, December 1991.

88. Waibel, T.R., Personal Journal From the Persian Gulf War, Oregon, California, Southwest Asia, 26 November 1990 to 9 April 1991.

89. Warner, Gordon, The Okinawa War. Naha City: Ikemiya Shokai \& Company, 1987.

90. Wheeler, Keith, The Road to Tokyo. Alexandria: Time-Life Books, 1979.

91. Whipple, A.B.C., The Seafarers: Fighting Sail. Alexandria, Virginia: Time-Life Books, 1978.

92. Whipple, A.B.C., To the Shores of Tripoli: The Birth of the U.S. Navy and Marines. New York: William Morrow and Company, Inc., 1991. 


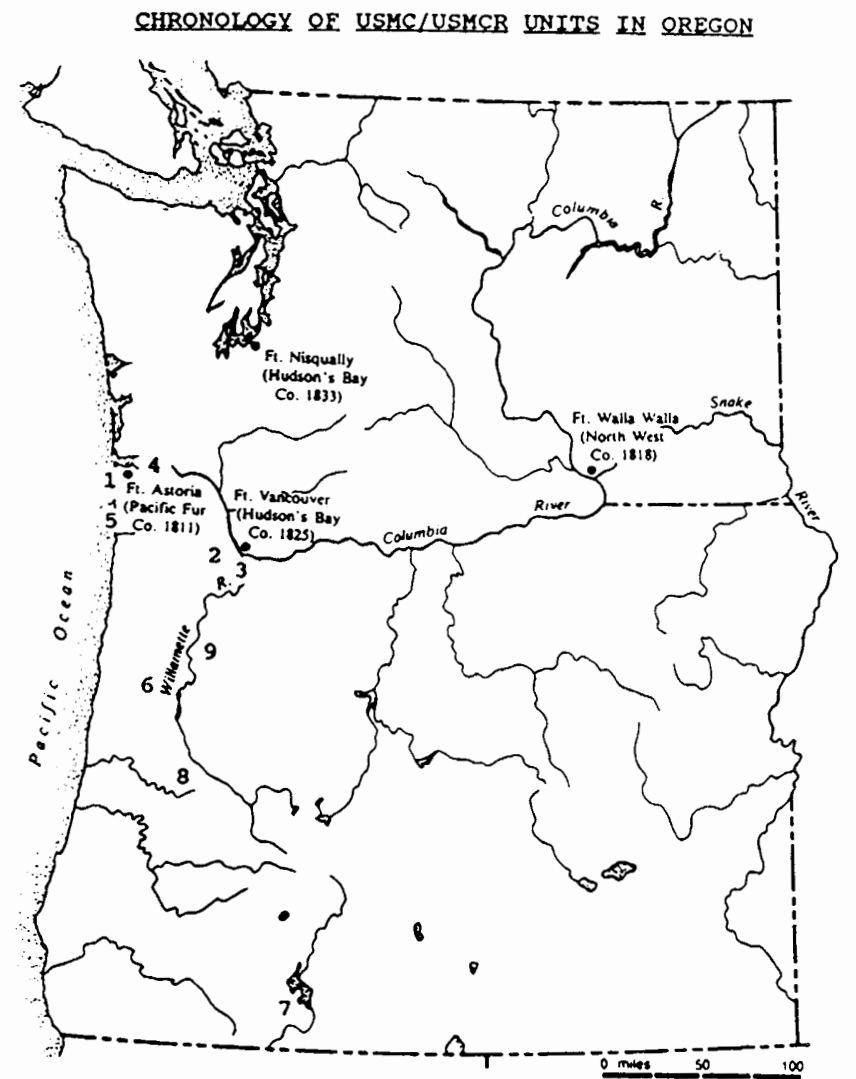

1 Meroan (tiret arrival of USWC) (vitite to rt Miequeliy, rt Vancouve

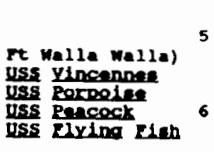

33 Marinee under:

Quarteraseter Sergeant Marion Albert stearne, USKC

$$
24
$$

2 romprusp (USWC)

Recruiting station

1910 to present

Eventuiliy include these

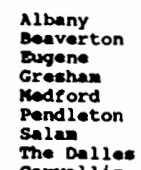

officer selection office:

Corvalis:

3 montuNid (USACR)

(Oregon State University)

Company F, 11th Battalion (Intentry), uSS Oreagn

20th Battalion (Infantry)

1940 (1940, ectivated for World War II)

4 th 105 Howitzer Battalion

1947 to 1950 (1950, ectivated for korean Wer)

17 th Eng ineer Company

2nd 1947 to 1950 (1950, also activated for Korean war)

2nd Engineer Fi.

oth Engineer company

1951 to 1957

3rd Engineer Battalion

1957 to 1962

Sth Engineer Battalion

1962 to 1967

10th Eng ineer Battalion

2967 to 1971

6th Eng i neer Battalion

6 th 1971 in 1976

Engineer Support Battalion

1976 to present (1990, activated for Gulf war)

4 Metoria (USHC)

Marine Barracks Astoria, Mavel Air Station Tongue Point
1939 to 1946

\section{Trwanoor (USWC)}

Marine Barracke Tillenook, Maval Air Station Tillasook

conerase (usic)

Marine Air Group 35, marine corps Air racility corvallie 1944

Xhangm ratse (USHC) 1944 to 1946
Marine Barrath Pell.

- EOome (USACR)

Battery B, th 105 Howitzer Battellion

1947 to 1950 (1950, activated for Korean Har)

1951 to 1962

Company B, 5 th Enginear Battalion

1962 to 1967

Company B, loth engineer Battalion

1967 to 1971

Company D, 6th Engineer Battalion

1971 to 1974

Service Company, 6th Engineer Battalion

Detachmont 1, 6th Engineer Support Battalion

engineer Platoon, Company A, 6th Engineer Support Bn

1989 to 1994 (1990 6th Engineer Support Bn

ridge Company B, 6th engineer support Bn War

1994 to present

9 GALEX (USMCR)

Battery $C$, 4th 105 Howitzer Battelion

rd 155 Gun 1950 (1950, activeted for Korean War

1951 to 1962

Company $A, 5$ th Engineer Battalion

1962 to 1967

Company A, 20th Engineer Battalion

1967 to 1971

Service Company, 6th Engineer Battalion

1971 to 1972

Service Conpany (-) (Rein), 6th Engineer Battalion

Company $A(-)$ (Rein), 6th Engineer support Battalion

Company A, 6th Engineer Support Battalion

1989 to present (1990, activated for Gulf war) 


\section{KEY DATES IN OREGON MARINE HISTORY}

1841 Astoria: Arrival of first United states Marines with wilkes Expedition: 33 Marines under

Quartermaster Sergeant Marion Albert stearns aboard USS Vincennes (flagship)

USS Porpoise

USS Peacock (wrecked on Columbia bar)

USS Flying Fish (first US Navy ship to enter Columbia River)

1910 Portland: First Recruiting office

253 1/2 Washington Street under Sergeant Thomas $w$. Dench

1930 Portland: First Reserve unit Company $\mathbf{F}$, 11th Battalion, commanded by Captain Albert G. Skelton USMCR Headquartered aboard battleship USS oregon

1939 Astoria: Marine Barracks, Naval Air Station Tongue point (aircraft \& ammunition security)

1943 Tillamook: Marine Barracks, Naval Air station Tillamook ( $\mathrm{ZP}-33$ blimp squadron security)

1944 Corvallis: Marine Corps Air Facility, Marine Air Group 35

Klamath Falls: Marine Barracks (US Navy therapy and research facility for Pacific War combat fatigue, malaria, filariasis)

1947 Eugene: Reserve unit

Battery B, 4th 105 Howitzer Battalion

Salem: Reserve unit

Battery C, 4th 105 Howitzer Battalion

\section{OREGON MARINE RESERVE UNIT WARTIME ACTIVATIONS}

1940 World War II

20th Infantry Battalion (Portland)

1950 Korean war

17th Engineer Company (Portland)

4 th 105 Howitzer Battalion (Portland, Eugene, Salem)

1990 Gulf War

Combat Engineer Platoon, HQ Co,

6 th Engineer Supt Battalion (Portland)

Company A, 6th ESB (Salem)

6th Bridge Company, 6th ESB (Eugene) 


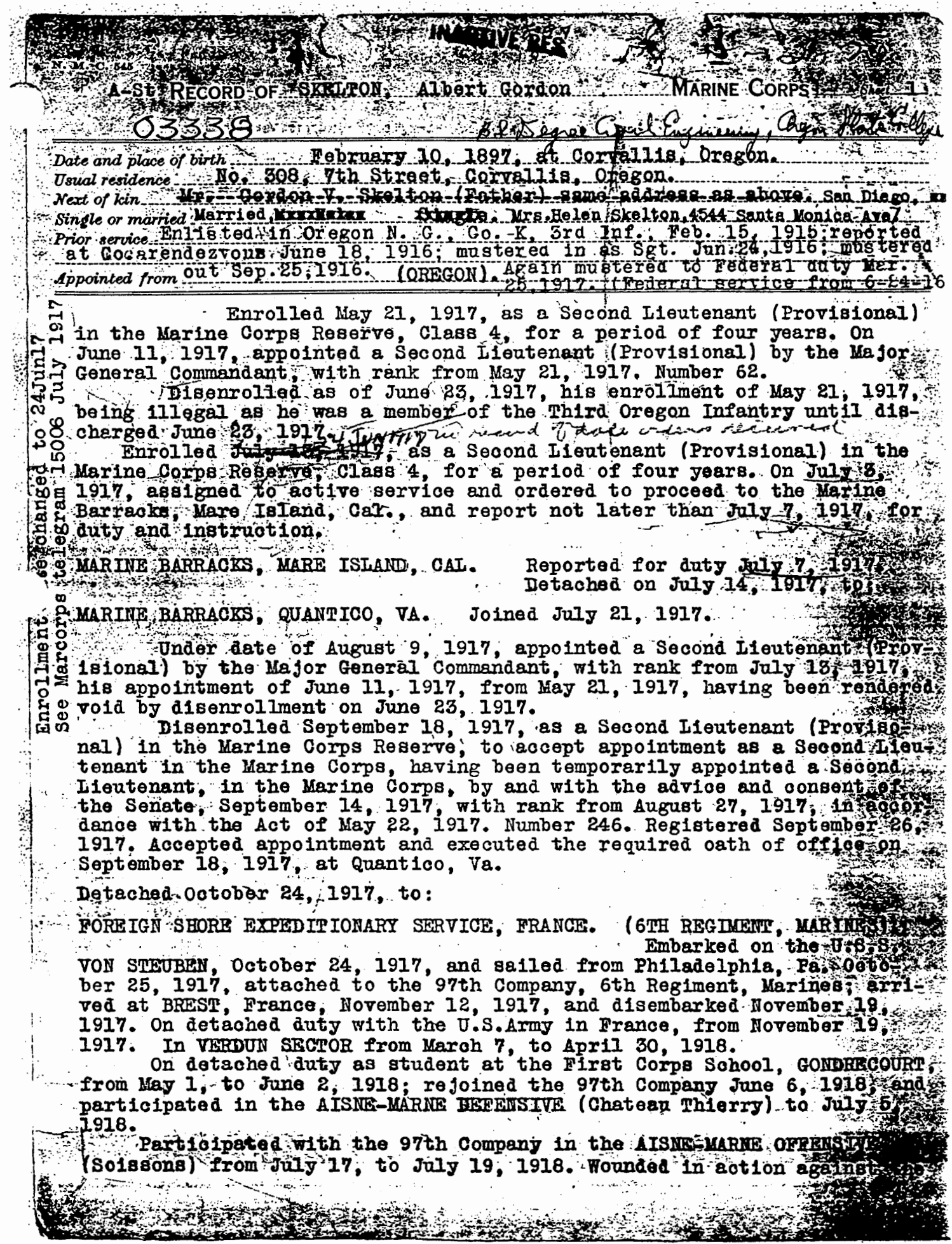




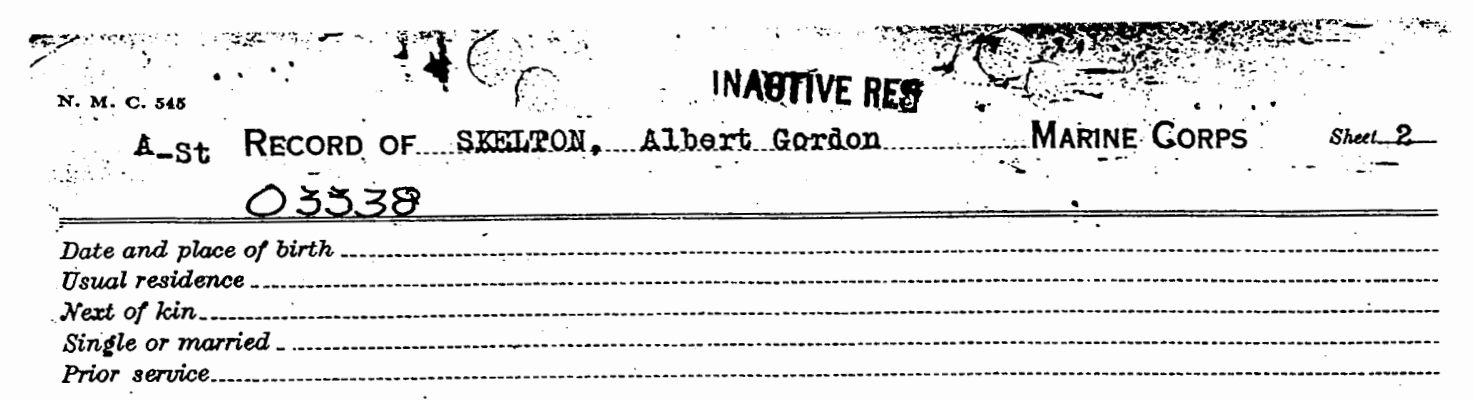

$\frac{\text { Appointed from }}{\text { FOREIGN SHORE EXPEDTIIONARY SERVICE, FRANCE. (Continued). }}$

enemy Jury' 19, 1918, and evacuated to the French Hospital UIXIE-CAEN, same date; returned to duty with the 97 th Company, 6th Regiment, on September 12,1918, and participated from that date in the ST. WIHIEL OFFENSIVE to September 16, 1918.

Temporarily appointed a First lieutenant, by and with the advice and consent of the Senate, September 6, 1918, to rank from July 1, 1918. Iumber 173. Registered September 9, 1918.

Participated in aommand of the $97 \mathrm{th}$ Company in the MEUSE-ARGONNE OFFans IVR (Champagne) from October 1, to October 9, 1918.

Partiolpated wih the 97th Company in the MEUST-ARGONNE OFFENSIVE (Argonne Forest) Irom November 1; to Norember 11, 1918.

Partioipated with the 97 th Company in the march to the RHINE RIVER by. way of Belgium and Iuxembourg, from Hovember 17, to December 13, 1918; crossea the RHINE RIVER, December 13, 1918, and stetioned at IFUTHSDORF, Germany, from December 14, 1918.

Temporarily promoted a Captain, by and with the advice and consent of the Senate, March 5, 1919, with rank from Jaly 2, 1918. Number 144. Registered March 5, 1919.

Ararded CROIX de GUEREE with siliver star (Citation Ordro Ho. 13,504 "T"

February 14; 1919) cited as follows:

i' From the 3rd to the 9th of October 1918, near ST. ETIENNE-a-ARNES his company oommander having been killed he has been put in command due to his courage. His bravery and his qualities of leacership has kept up the morale of his men."

Detached July 27, 1919, from further duty with the American Expeditionary Forces, France, to the United States; embarked on the U.S.S. WILHEIMINA and sailed from BREST, France, July 27, 1919; arrived at Hoboken, N.J., August 6, 1919, and proceeded to Camp lifls, Iong Islend, N.Y.; thence to the Harine Barraoks, Quantico, Va.

MARINE BARRACKS, QUANPICO, VA. Joined Aggagt 9, 1919, and detached that date from further gervice with U.S.Army.

By direction of the Presiaent, honorably discherged from the United States Marine Corps, August 15, 1919; effective Augast. $20 \% 1919$. CITED : A.E.F. Citation Oxder No. 4, $p, 41$, by Commanding General, AEF: "FOr gellantry in ection in the CEAYPAGNE SECTOR, France, Ootober. 3-9, 1918, and for his brilliant leadership of his compang." 
11th Sattalion, U.S.M.C.R. / U.S.S.Oregon / Pertland (refon / 1939 tc 1940 / 105ren on rister

? Anthens, Paul $\mathrm{B}$.

Bakor, Donald

Baker. Oliver Wendell

- Blackburn, Herbert

Brannenburg, Kenneth/2136-Sylvan/West Linn 97068/ph.636-2260

? Erightman, Howard

? Brightmen, Jack

Combs, Jack/Box 537-Elsie Rt/Seaside 97138/ph.775-2242

- Cosby.

- Carter, E.J.

Cramer, John B.

* Cranl, Homer

- Crosby. Darrell

* Callison, Paul G.

Doran, Daniol

DuCha teay, Theo

? Dutton, Harry

- DeSantis, Ed

Eck, Noel /2386-W-Burnside/Portland

Everts, James/32400-Boones Bend Rd/wilsonville/ph.694-5594

- Favier, Ed

* Forretti, Elmo

Forrett1, Fred

Frledstrom, Ben /5431-Colony C1r./Milwaulkie 97222/ph.659-6390

Erkenbeck, John

? Gullings, Vernon 0.

* Gunderson, Kenneth

* Hagen, Donald

? Hall, John

? Holly, Fay

Holzapfel, Daniel/6536-N-Cambe11/ph.283-1545

Hammerin, Robert

Johnson, Ted/1621-SE-Knapp/97211/ph.238-1615

Kust, Joe

Lucior, Roy/10134-SW-50th/ph . 244-2847

Ward,David

Whipple,

Wagner, Capt. Llcyd $\mathrm{E}$.

* Hundley, Ray. E.

? LaBonte, Robert

* Little, Robert

Lemcke, Julius 0.

Nachamer, John

Niller, Eugene

? Nad

Natthews

Narshall, Clair

Morgan, Leonard/900-NE-Franc18/Gresham/ph665-4838

Neyers, Joseph

Niehoff, Harry/13455-SE-Lucille/97236/ph.761-1426

? Nugent, Nercus $Y$.

* Nowlin, John

? Pulliam,

* Price, Edward

Pearson, Walter/ -SE-Knapp/ph.774-1774

? Poley, Robert

? Rose, Thomas

Riesbeck, Henry/12012-SE-122/97236/ph.698-3621

* Rader, Clarence

* Schroeder, Edward

* Sisson, Dr. Kerle

* Skelton, Albert

Steele, Dale

Smith, Howard L.

* Tolman, Jchn

? Tyler, 


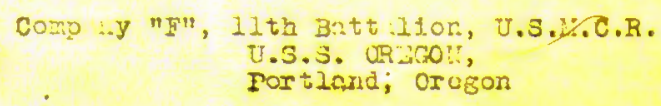

\section{$-\frac{3}{\operatorname{ser} 11,1940}$ DAT?}

From: Tho comianaing ofricos.

TO: Privato Jarry B. T. IIrgorr, osuch $(0)$.

Subjuot: ordors.

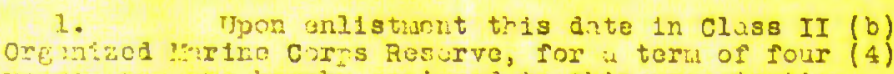

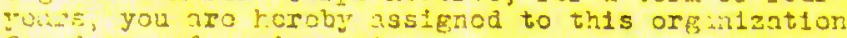

for liuty ald lectenmit:t.

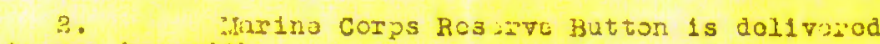
to you hurwith.
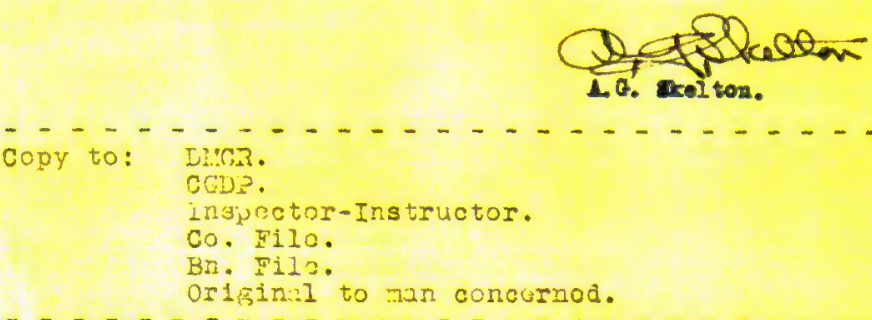
UNITED STAMES MARIND COPPS RESERVE,

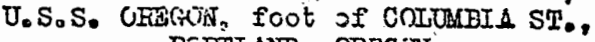
PCRTIAAND, OREGUN.

Telephone ATrater 0501

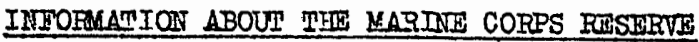

Q. What is the Harine Corps Reserve?

A. It is a federal military organization of patriotlo citizens who are rilling in time of peace to train for service with the Marine corps In sime of var, or national emergency. The Marine Corps Reserve is a ccmponent part of the U.S. Marine Corps whieh, in tarn, is an integrel part; of the U.S. Naval Service. Units of the Marine Corps Reserve are to the Marino Corps what units of the Maval Reserve are to the Nary and, in a general way, what the Nationsl Guard is to the U.S. Army.

Hote: The Marine Corps ig the military branch of the Naral service and f.ts principal purpose is for use in Navel oporations requiring the lending of a highiy skilled military force. For extrie, at prosent a gimont of jHarines is in Chins for the purpose of prow tscting tmericen ilfe and property. Mhese. Marinos are pporating as a parc of the Asiatic Flent of the Unifed States Navy. Other Neval oporations to resent jears roquiring large expeditionary forces of Harines vere the cempaign in Hait1, NIcaragua, and the Domintican Roprablic.

Q. What are the advantages of joining the uarine Oorpe Beserver

1. There are many, the principal are:

(1) The profession of ams is an honorable one; toblt we ore. the extistence of our nation.

(2) Byc joining a oltiren military or naval organization a young man very definitely piaces himulif among the abstantiel residents

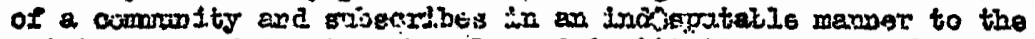

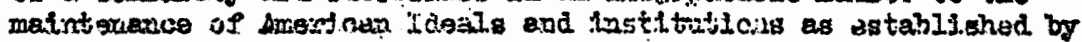
tho fourders of this ratich. The resarift thes his giand with

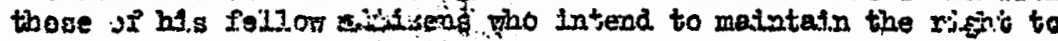

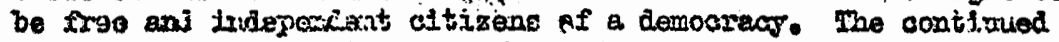

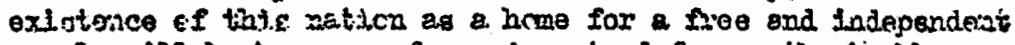

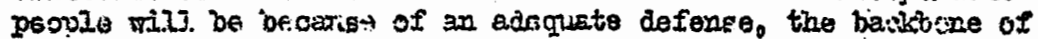

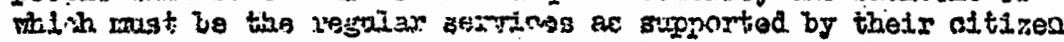
milifary and rarci. comporients (National Guard, Navy Paserve, Harine Corps lesorro, oicu).

(3) In case of national emergency, the reservist assures himgelf

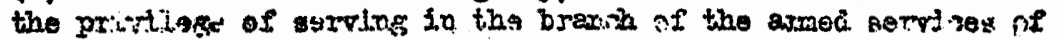

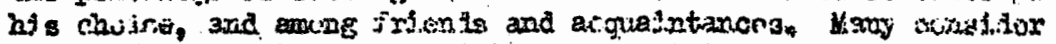

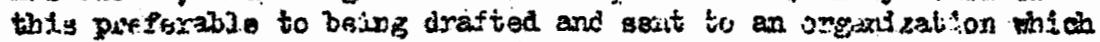
may rut be of thoir cinoosing and probabiy atray from fribnjo and acguelutancase

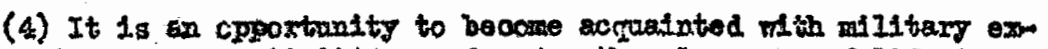
perienses activitien, and enjoy the pleasures of life in carp and Llati. 


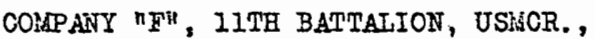

U.S.S. OREGON, PORTLAIND, ORTGON, 10 June, 1940.

COMPAIYY TRAIUING ORDER)

ITC. 1:

1940)

ANNUAL FIEDT TRAINING 1940.

Reference: (ä) Itr CG,DP, 2975-95-56-clp dated 20 liay 1940.

1. The reference directs this organization to conduct anmual. fleld training at the Marine Barracks, Puget Sound Navy Fard, Bremerton, Fashingtion during the period 16 to 30 June, 1940.

2,

All members of the company will adhere strictly to"

the following instruotions and schedule; $10 \mathrm{PM}$ sat. 15

ASSTBRTY:

June, 1940.

PLACR OF ASSEABLY;

DTPART FROK USS OREGON:

DEPART PORTLAED, OREGONL

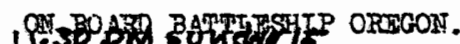

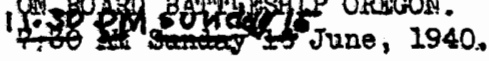

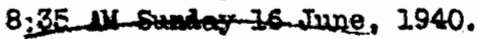

UTIFORM:

i. Service Minter (armins) w/out

legelngi, Girrison Cap, (the

$\because$ Fleld Hat wlI be slung over the

buponet bandle when the pack is worn).

EQjirminat;

Comber pack - Rtile.

3. Clothing (STiA) bags wili be iseued together with shipping tage; these bags are equiped for locks; and MUST be locked, ihe

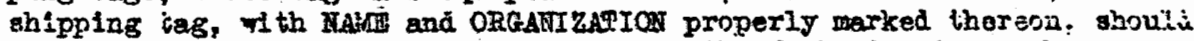
be secureis fantened to the sea bag. Paok the following in sen bags,

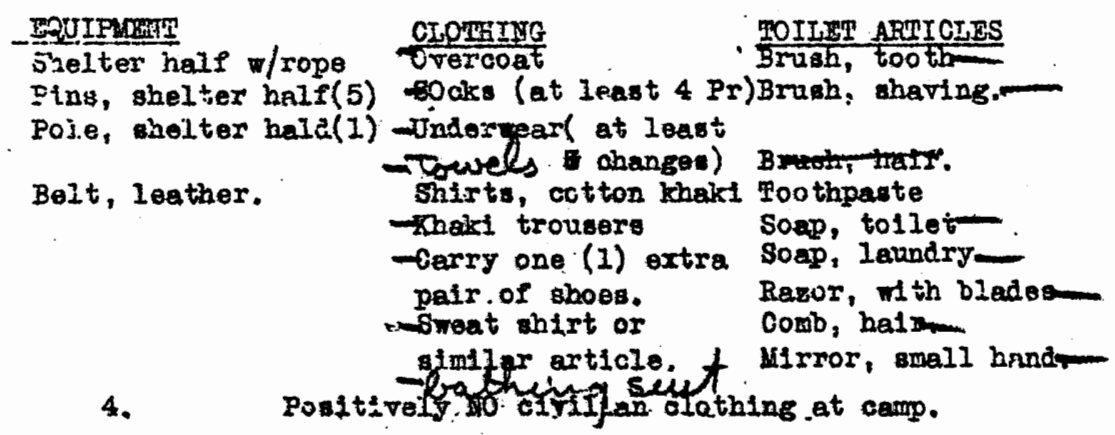

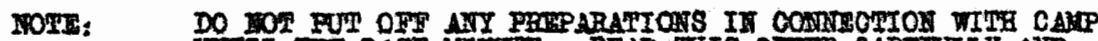

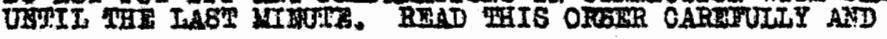
BD

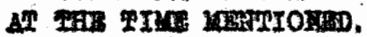

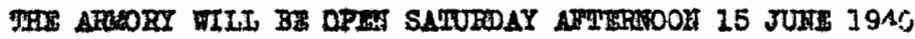

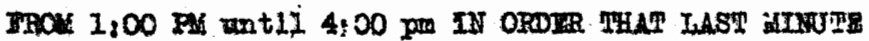
PRTRARAIIOAS BS COLPTEFED.

A. 0. SKR

Ozptain, U.S. Marine Coryos Reperve. Comending compung "F.. 


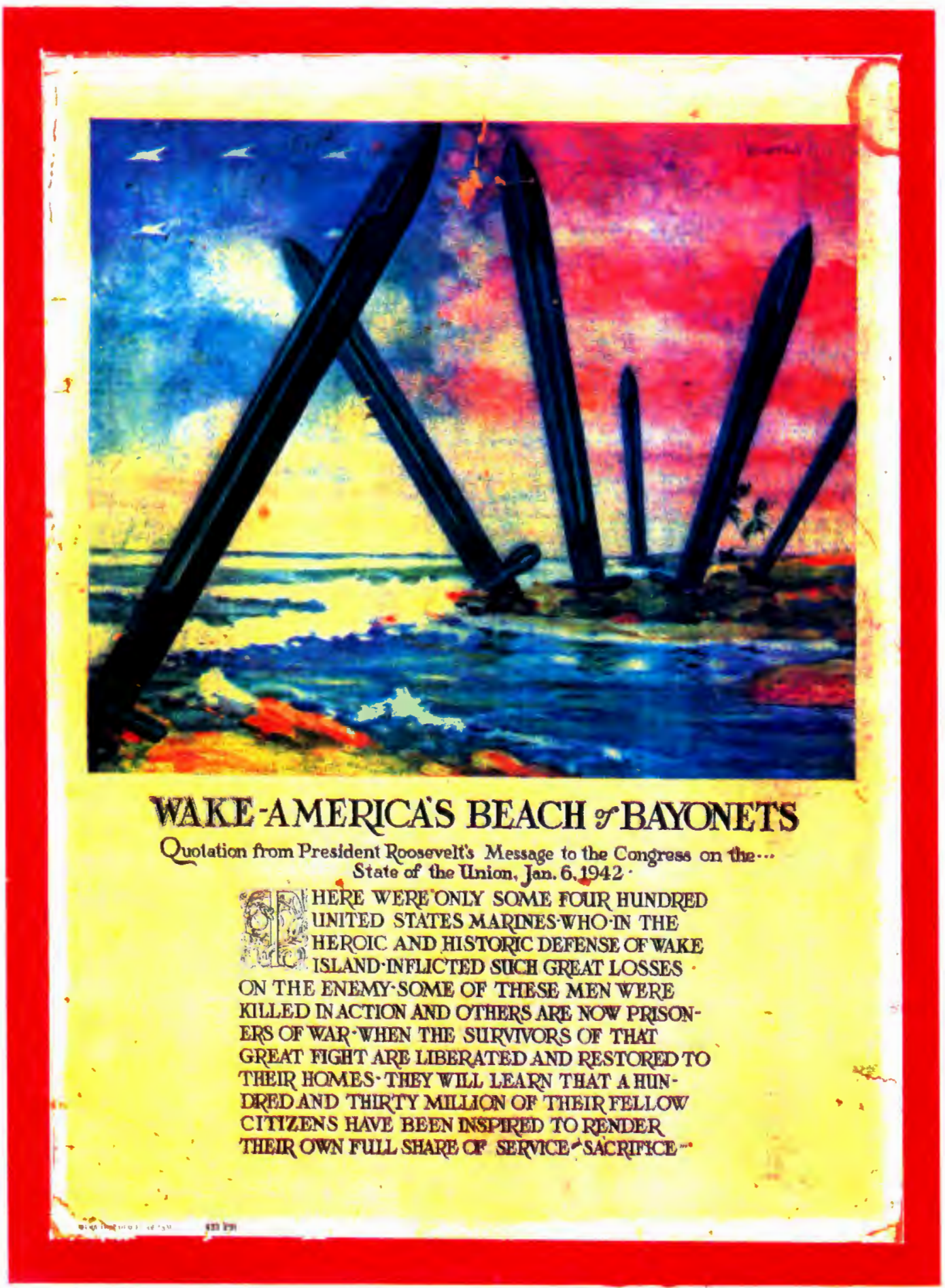




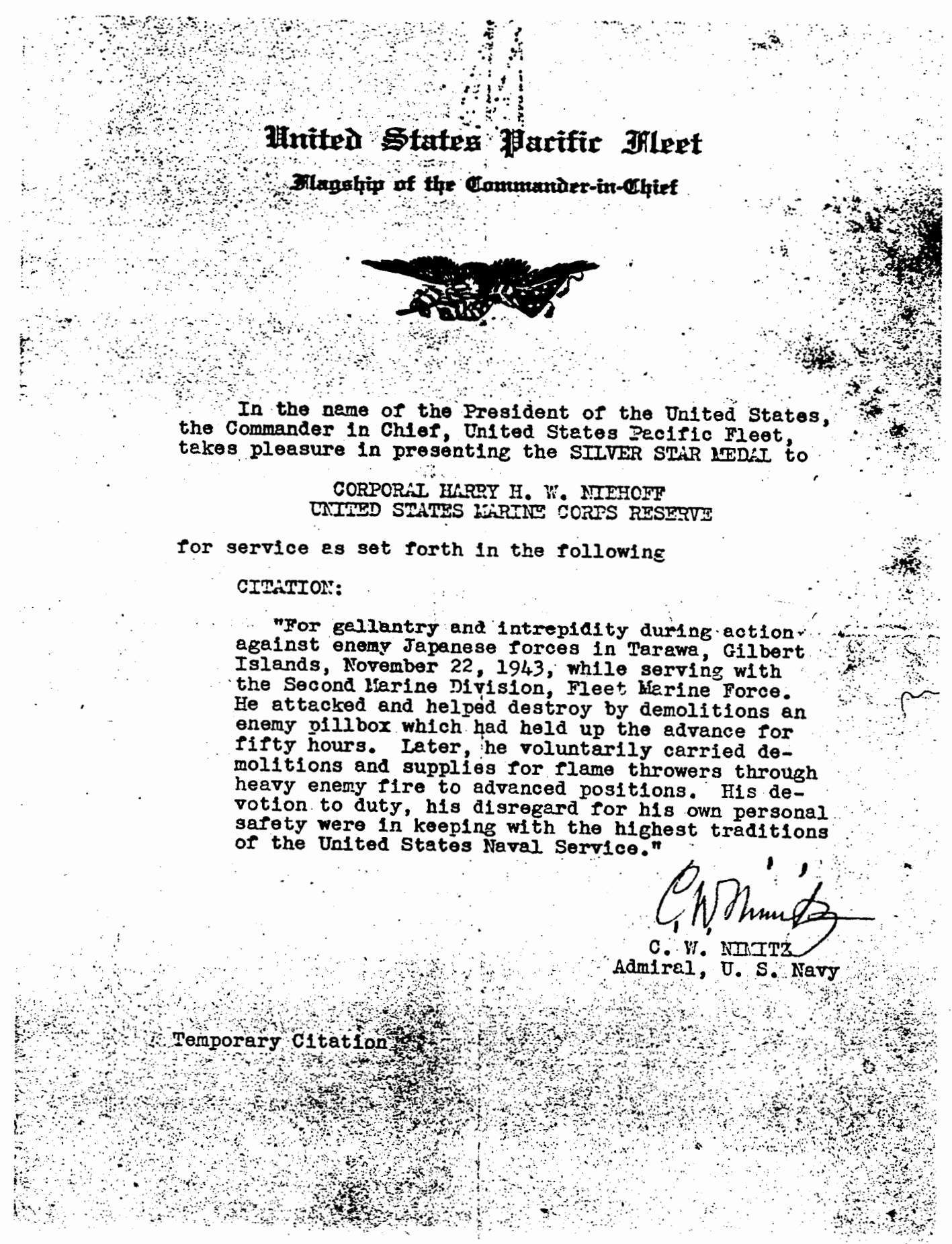




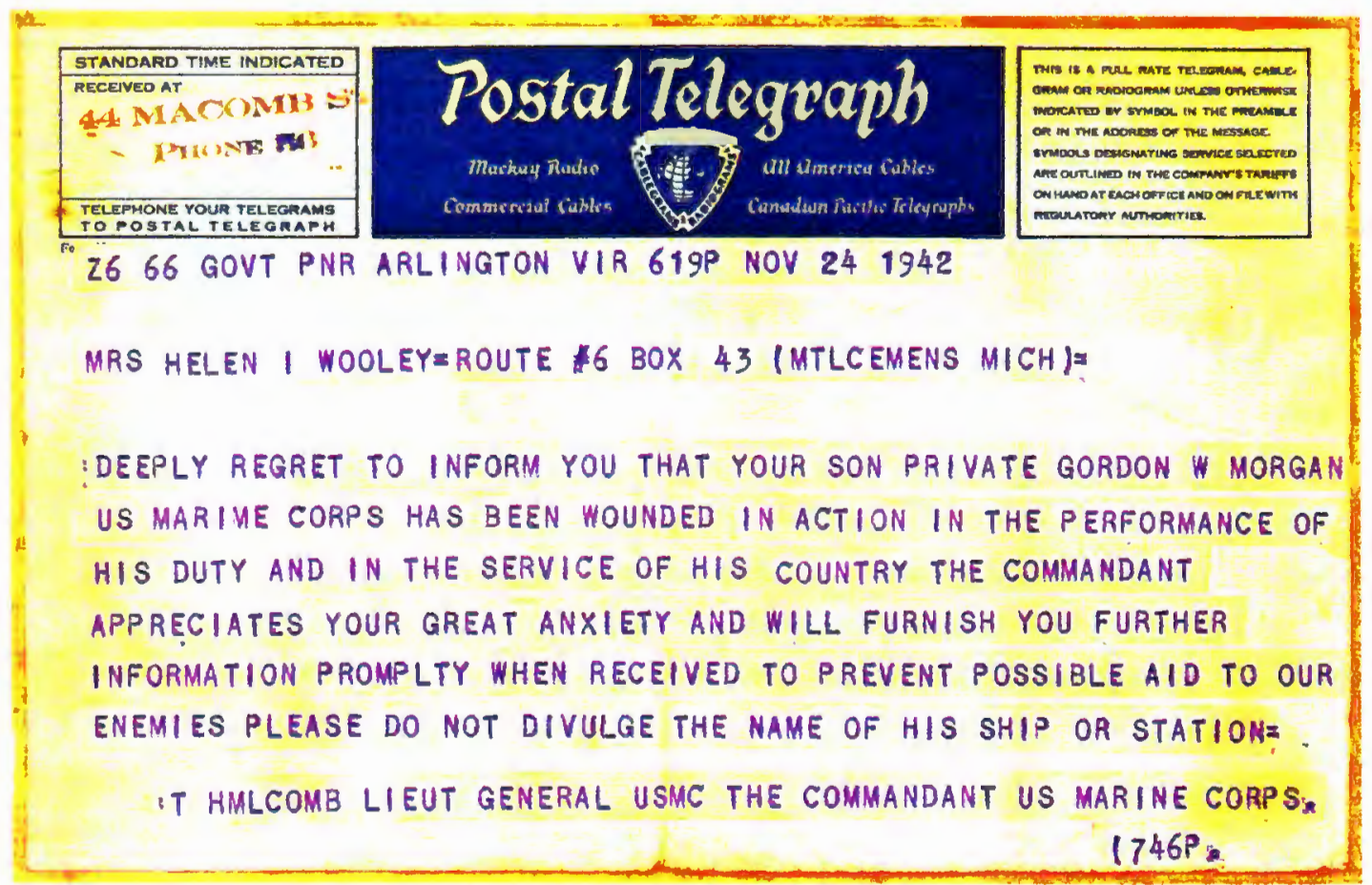


THE WHITE HOUSE

WASHINGTON

The President of the United States takes pleasure in presenting the MEDAL OF HONOR to

PRIVATE FIRST CLASS ARTHUR J. JACKSON, UNITED STATES MARINE CORPS,

for service as set forth in the following

CITATION:

"For conspicuous gallantry and intrepidity at the risk of his life above and beyond the call of duty, while serving with the Third Battalion, Seventh Marines, First MarineDivision, in action against enemy Japanese forces on the Island of Peleliu in the Palau Group, 18 September 1944. Boldly taking the initiative when his platoon's left-flank advance was held up by the fire of Japanese troops concealed in strongly fortified positions, Private First.Class.Jackson unhesitatingly proceeded forward of our lines and, courageously defying the heavy barrages, charged a large pillbox housing approximately thirty-five enemy soldiers. Pouring his automatic fire into the opening of the fixed installation to trap the occupying troops, he hurled white phosphorus grenades and explosive charges brought up by a fellow Marine, demolishing the pillbox and killing all of the enemy: Advancing alone under the continuous fire from other hostile emplace ments, he employed similar means to smash two smaller positions in the immediate vicinity. Determined to crush the entire pocket of resistance although harassed on all sides by the shattering blasts of Japanese weapons and covered only by small rifle parties, he stormed one gun position after another, dealing death and destruction to the savagely fighting enemy in his inexorable drive against the remaining defenses and succeeded in wiping out a total of twelve pillboxes and fifty Japanese soldiers. Stout-hearted and indomitable despite the terrific odds, Private First Class Jackson resolutely maintained control of the platoon's left-flank movement throughout his valiant one-man assault and, by his cool decision and relentless fighting spirit during a critical situation, contributed essentially to the complete annihilation of the enemy in the southern sector of the island. His gallant initiative and heroic conduct in the face of extreme peril reflect the highest credit upon Private First Class Jackson and the United States-Naval Service."

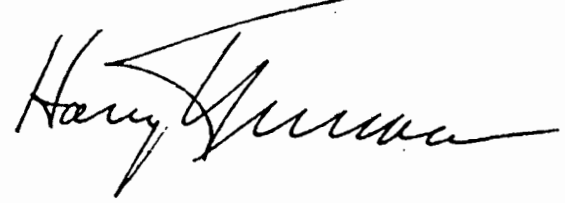




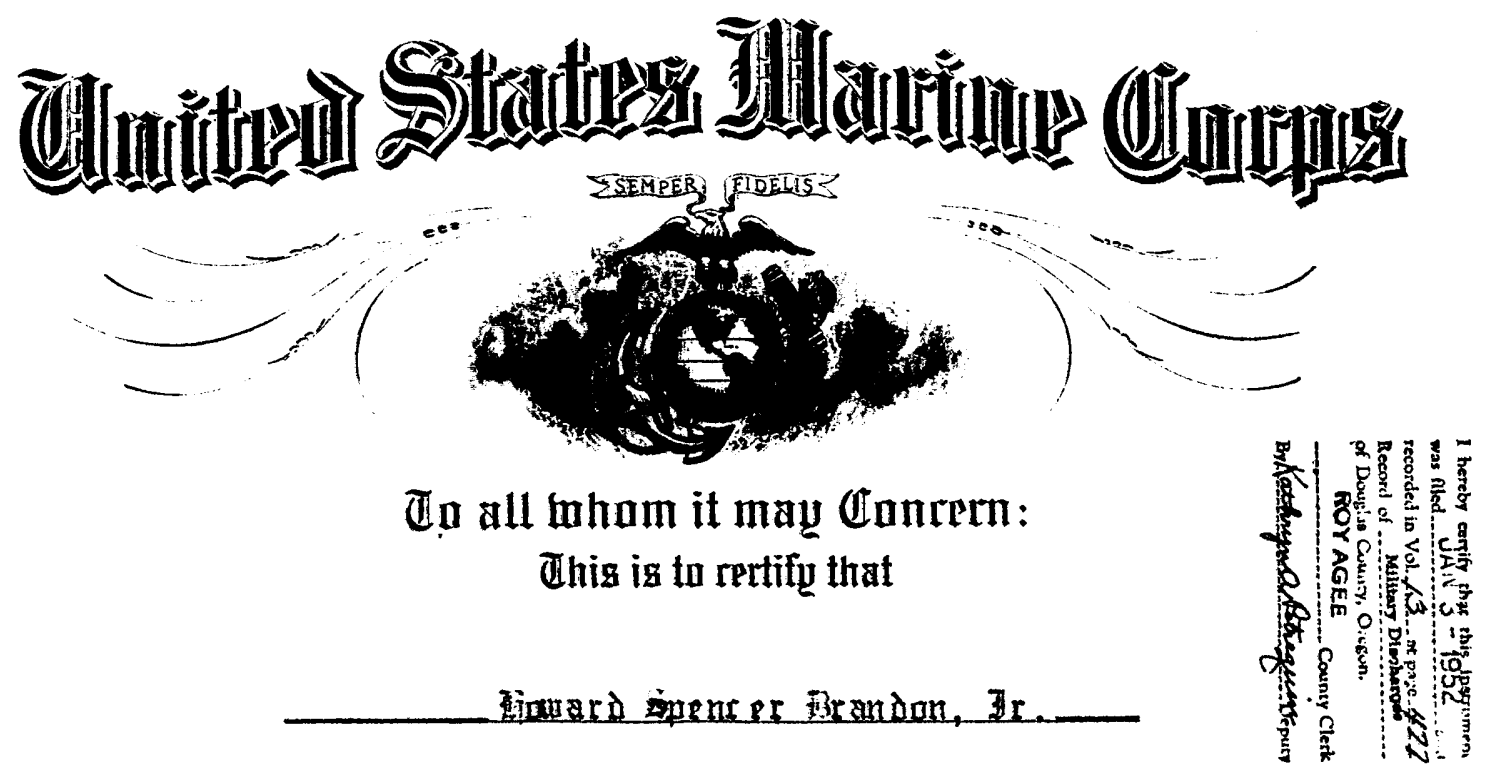

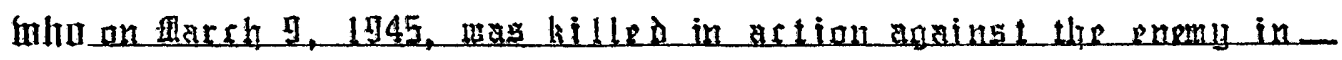

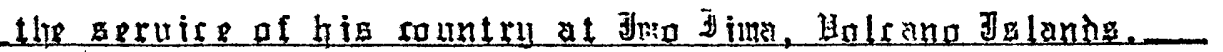

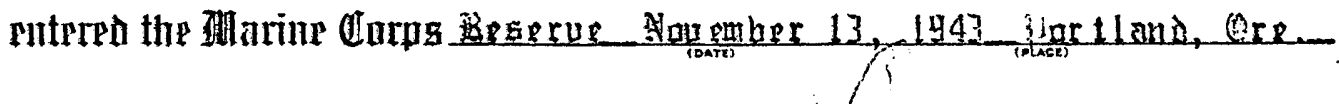

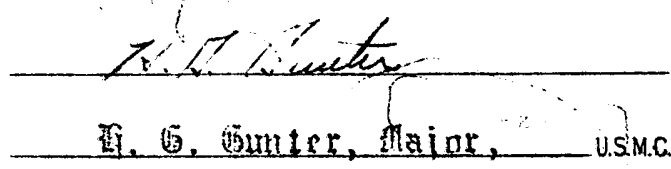

总 

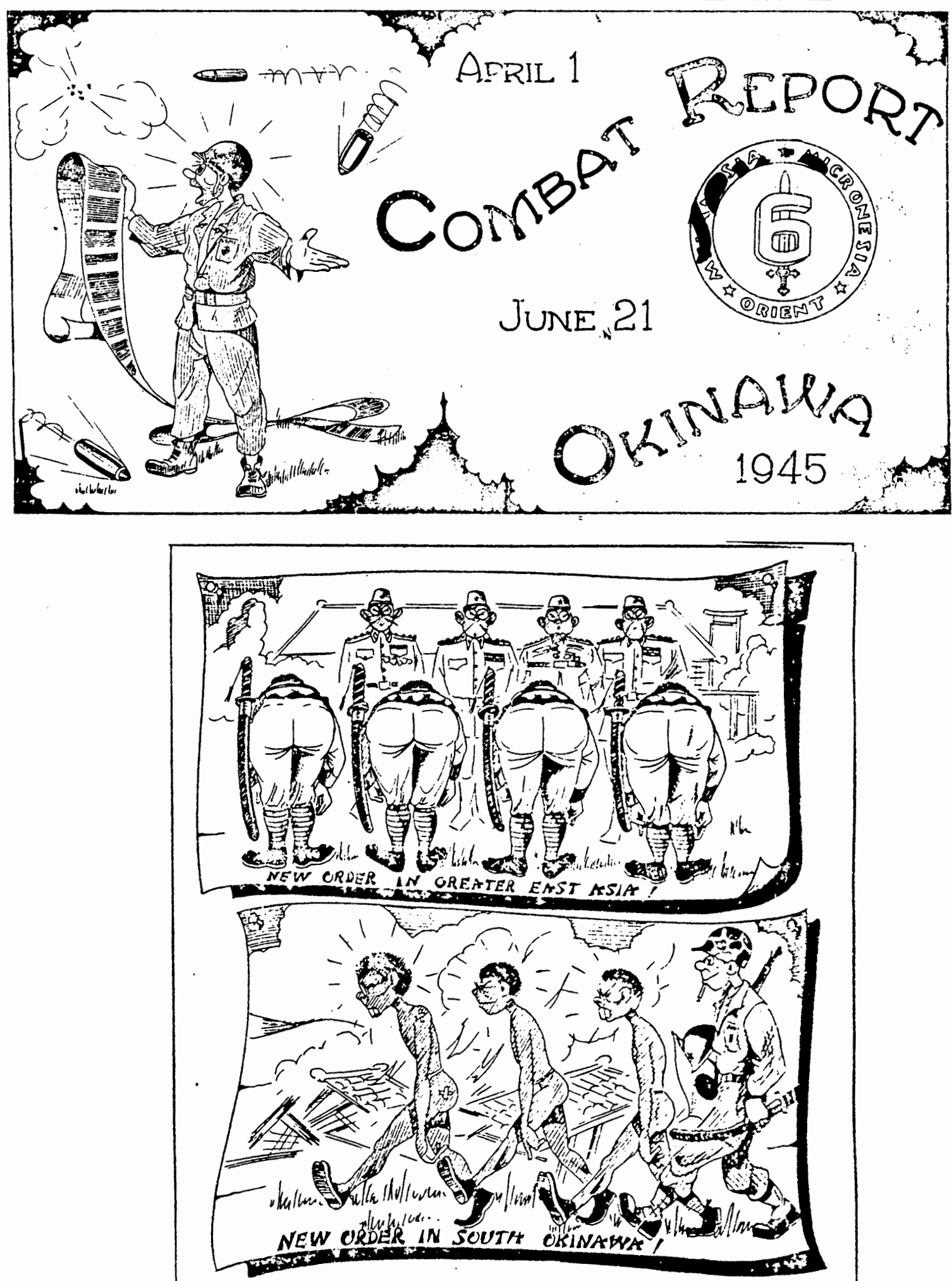


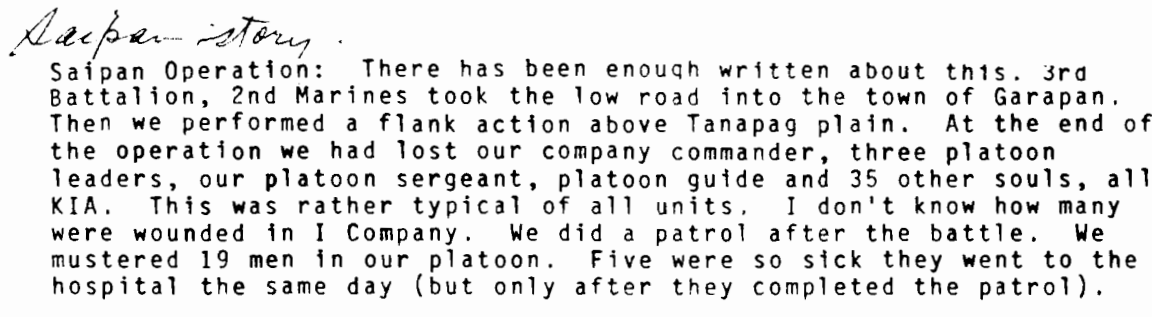

There is a true generation gap (maybe two) between the Marines of today, and the what we were 50 years ago. However, we have in common a devotion to duty and responsibility, do your damndest attitude, and win. Our crowd of 1942 and 1943 were not particuiarly devoted to the USMC, and in fact hated it much of the time. Realize that there was little military tradition in the general public from which we sprung.

It was only when in contact with other services, especially the us Army, that we appreciated being Marines. This attitude would be displayed where one might temporarily fall under an outside command. We would simply ignore orders from other services. We were combat people; they weren't. That simple. "Screw off". We were a touchy crowd that could only be handled by our own officers and NCOS. you can imagine the conflicts when we would go aboard a Navy transport.

There were no good times. The USMC provided no good times. He were kept under strict discipitne at all times; four roll calls per day, sequestered from "forelgn" troops such as the US Army and US Navy, in the field seven days a week, all day - every day, few amentties, no leaves, no furloughs. In those years there was one rotation of Marines stateside; those that had fought earlier at Guadalcanal. They rotated home two years later.

Well, there was a war going on, and we all figured it wouldn't last forever. We could put up with anything with that thought in mind. So, in 1945, we were glad enough to call it quits, take our plece of paper, and go home without any ceremony.

Yet there was a feeling about the corps that stayed with us, and it certainly wasn't one of love or effection. The sentiment was patriotism, and the feeling that individually we had done our best to perform duties as best we could. We were proud of our performance as NCOS, or junior offlcers. He were proud of our combat units. He were proud that we had proved to be good combat soldiers. Many of us jolned the Reserve in the next four years, and then served in Korea.

In late years, and recent assoctation with old-timers in the second Marine Division Association, I have come to really apprectated those people only 4 or 5 years older than me. These are, were, the pre-war Marines. From a slfm cadre of 19,000 people in 1939 thay managed to train, and make combat-ready the first generation of the WH II Martnes, the lst and 2nd Marine Divisions. This was a suplirb performance, and was not matched by the other services. Everything was lacking at that time, the training was not particulariy good, but the Marine Spirit, Semper Fidelis, was instilled in all. The new guys may not have loved the Corps, but they all caught that spirit.

$$
\text { D) Dre Denteken }
$$




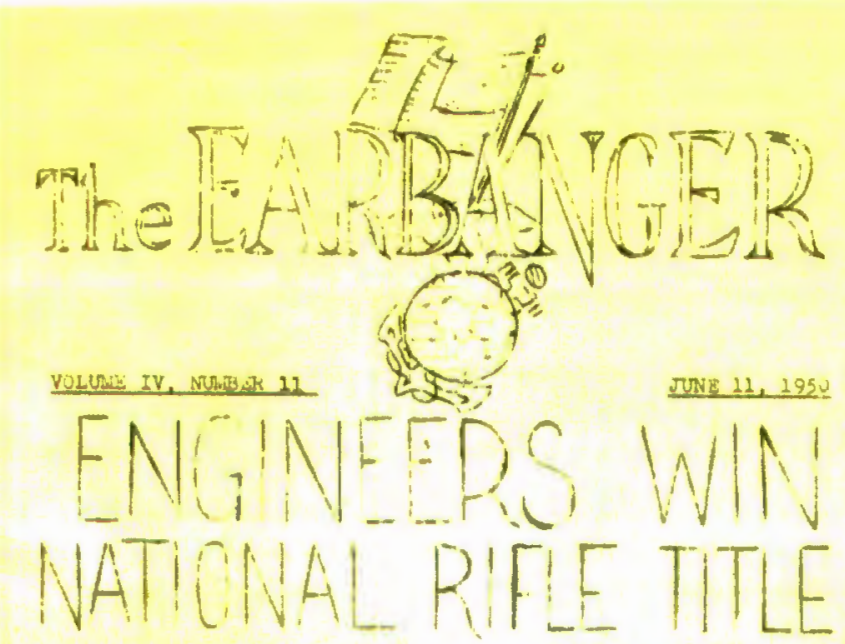

Word thit the 17th sinelamur Cowplay riflu tuc.t hag won

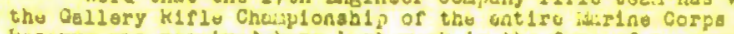
kagervis wh roculvod huTu lust whak in the forid of a pursonul

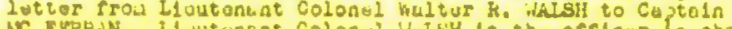

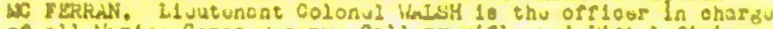
of all Murino Corpa Kusurvo Callury kiflu und Hatol Iringe

The raot thet tho sachaura won thls ntelonul tielo 15

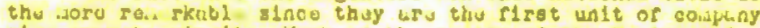
aldu over to win 1t. Muoh of thu sucoss of the bisingors" toaj oun bo ctirlbutud dirat2y to this tidu und affort put

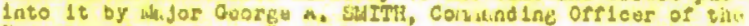
Sovuatonth aglneor Comingy.

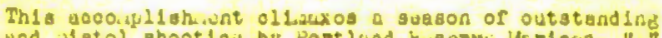
rldt und platol shootlas by portluad huservu harinus. "n" Buttury, 4th logut How1tzur Buttuliod won tho Spokano Cup by tuklas tho pletol orown of tho 23 th iturino corps Huturve Diatrict. The inglnoura also wero undafurtad la tho Wusturn Cospany k1slo Lasulue tind won thu Buldwin Trophy for thu seond congucutlve yeur by wiral nt the 13 th bur 1 ne corpo

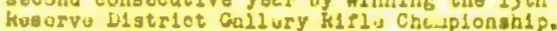

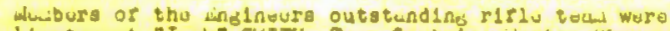
Plret Lloutonunt "Juokm SuITH, Tuc CGptz1n; isstor ihrgetne

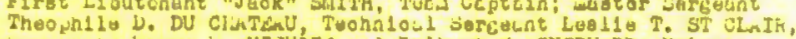

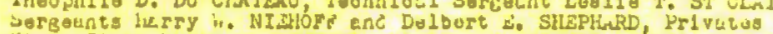

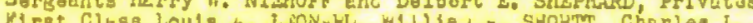

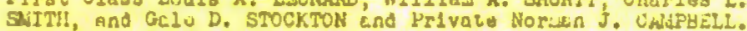

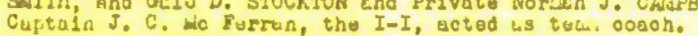

Plrine for the "n" Bcttury platol chmps ware Corporel

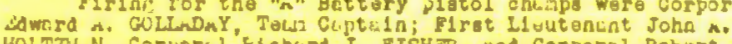

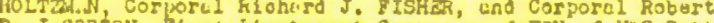

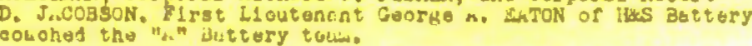


Marines Hymn

To the Editor: My husband is a physician, and now in Po. hang, Korea.

He sent this new version of the Marine Hymn and I am sending It on, as there may be a few more that may enjoy reading how our boys have a way of expressing differences of opinion.

Marine Hymn-Now Voralon From the halls of Montezuma To the shores of Tripoli We'll pollce old Harry's navy As long as they're at sea.

First to flght the army's battles And to win Korean fights And still our old friend Harry Tries to louse up our rights.

Our Alag's been flown $150 \mathrm{~m}$ every ship

Since the navy had its start

A marine detachment in their midst

Kept the 1 le et from falling apart.

Uncle Harry says we're $j u s t$ pollce

And he should really know

We've arrested wars since they began'

And dealt the final blows.

We love honor, we love glory

We're the tinest ever seen -

But still our propaganda

Is a second-rate machine.

Harry's army and his navy

Never Jook on Korea's scenes

'Cause they know the angels are in love

With the United States marines!

MRS. : VARNON L. SUMMERS,

1137 N. Prescott. 
THE WHITE HOUSE

WASHINGTON

The President of the United states, in solemn

gratitude, presents the MEDAL OF HONOR, posthumously, to

PRIVATE FIRST CLASS GARY W. MARTINI, UNITED STATES MARINE CORPS

for service as set forth in the following

Citation: For

conspicuous gallantry and intrepidity at the risk of his life above and beyond the call of duty. On 21 April 1967, during Operation UNION, elements of Company F, conducting offensive operations at Binh Son, encountered a firmly entrenched enemy force and immediately deployed to engage them. The marines in Pfc. Martini's platoon assaulted across an open rice paddy to within 20 meters of the enemy trench line where they were suddenly struck by handgrenades, intense small arms, automatic weapons, and mortar fire. The enemy onslaught killed 14 and wounded 18 marines, pinning the remainder of the platoon down behind a low paddy dike. In the face of imminent danger, Pfc. Martini immediately crawled over the dike to a forward open area within 15 meters of the enemy position where, continuously exposed to the hostile fire, he hurled handgrenades, killing several of the enemy. Crawling back through the intense fire, he rejoined his platoon which had moved to the relative safety of a trench line. From this position he observed several of his wounded comrades lying helpless in the fire-swept paddy. Although he knew that I man had been killed attempting to assist the wounded, Pfc. Martini raced through the open area and dragged a comrade back to a friendly position. In spite of a serious wound received during this first daring rescue, he again braved the unrelenting fury of the enemy fire to aid another companion lying wounded only 20 meters in front of the enemy trench line. As he rearhed the fallen marine, he received a mortal wound, but disregarding his own condition, he began to drag the marine toward his platoon's position. Observing men from his unit attempting to leave the security of their position to aid him, concerned only for their safety, he called to them to remain uncier cover, and through a final supreme effort, moved his injured comrade to where he could be pulled to safety, before he fell, succumbing to his wounds. Stouthearted and indomitable, Pfc. Martini unhesitatingly yielded his life to save 2 of his comrades and insure the safety of the remainder of his platoon. His outstanding courage, valiant fighting spirit and selfless devotion to duty reflected the highest credit upon himself, the Marine Corps, and the U.S. Naval Service. He gallantly gave his life for his country. 


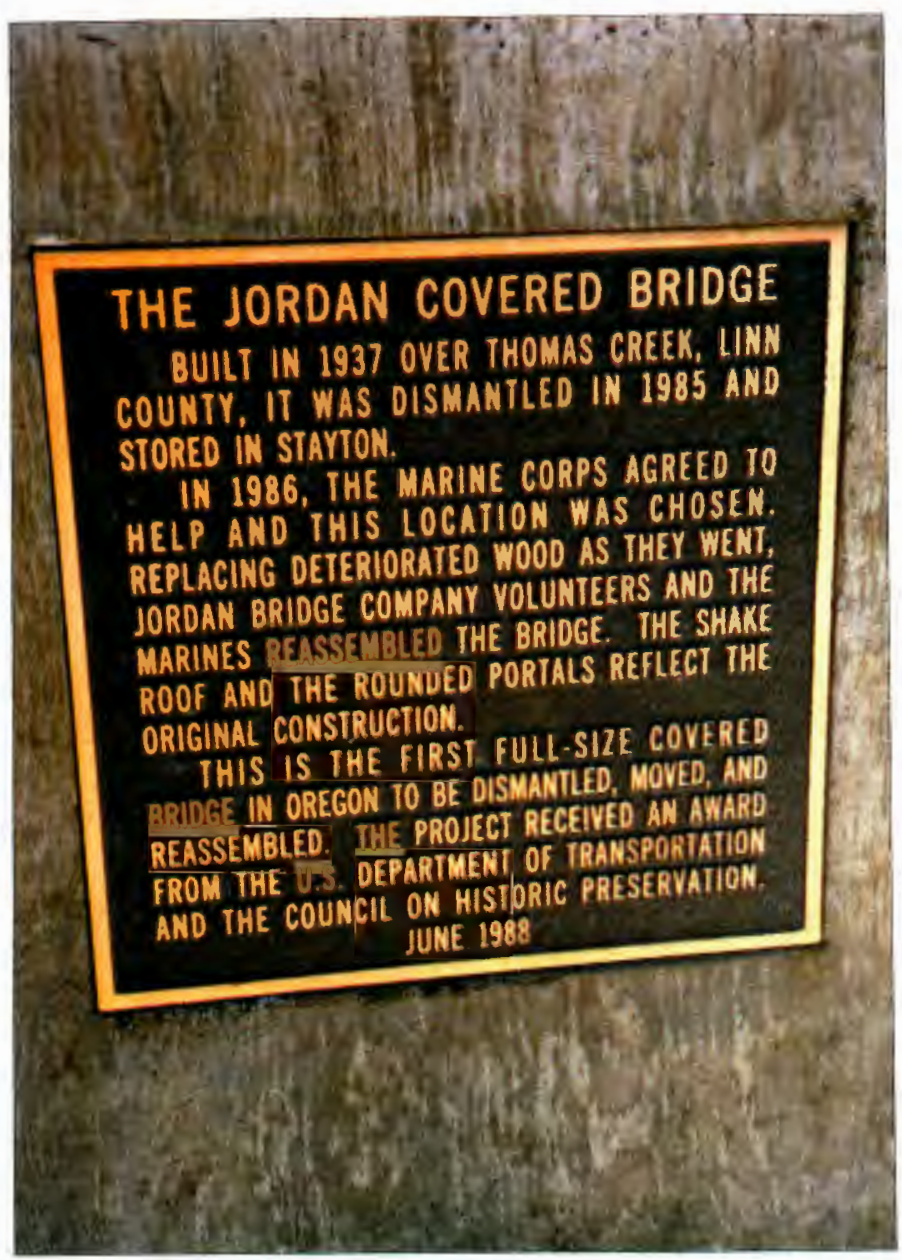


$10138 \%$

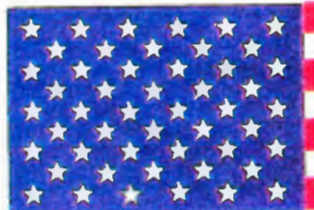

AAABIC

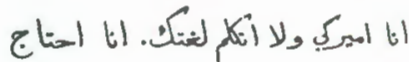

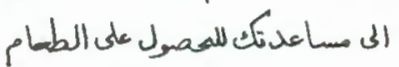

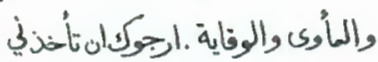

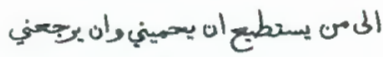

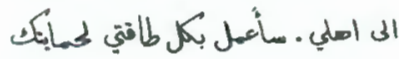

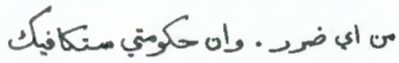
مكافاة على مسياعدتكي لي عندما تقدمون لها هذا الرقت مع نكر

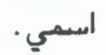
TUPNISH

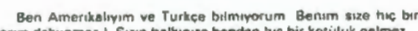

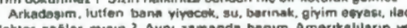

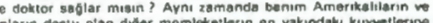

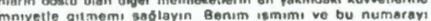

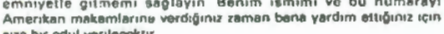

PERSIAN (FARSI)

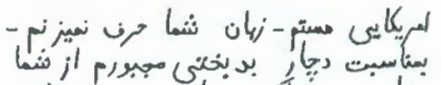

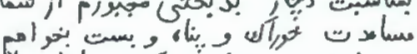

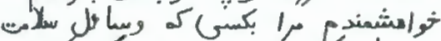

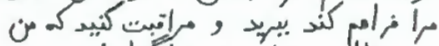

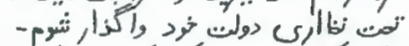

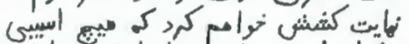

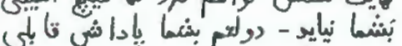

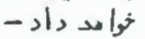

RUAOISH

من ته مريكيم و بـ زماني نبوه زمبه ناكهم

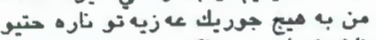

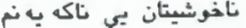

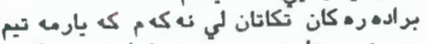

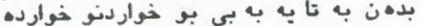

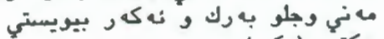

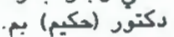

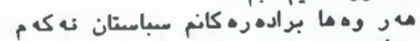

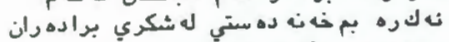

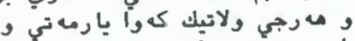

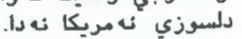

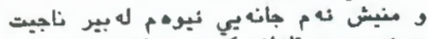

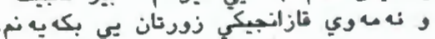

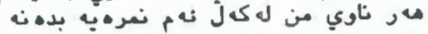

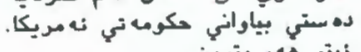

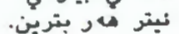

ENGLISH

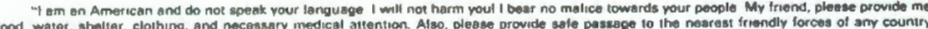

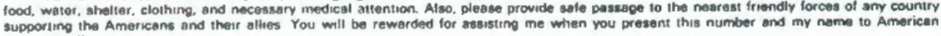
authortines 